Penha Elizabeth Pacca

\section{A estagnação urbana como parte da metrópole paulistana do século XXI - o caso do Pari}

Tese apresentada à Faculdade de Arquitetura e Urbanismo da Universidade de São Paulo como parte dos requisitos necessários à obtenção do título de Doutor em Arquitetura e Urbanismo

Área de Concentração:

Planejamento Urbano e Regional

Orientador: Prof. Dr. Flávio Villaça 
AUTORIZO A REPRODUÇÃO E DIVULGAÇÃO TOTAL OU PARCIAL DESTE TRABALHO, POR QUALQUER MEIO CONVENCIONAL OU ELETRÔNICO, PARA FINS DE ESTUDO E PESQUISA, DESDE QUE CITADA A FONTE.

E-MAIL:

Pacca, Penha Elizabeth

P114e A estagnação urbana como parte da metrópole paulistana do século XXI : o caso do Pari / Penha Elizabeth Pacca. -- São Paulo, 2010. 282 p. : il.

Tese (Doutorado - Área de Concentração: Planejamento Urbano e Regional) - FAUUSP.

Orientador: Flávio Villaça

1. Política urbana - São Paulo (SP) - Pari 2. Uso do solo São Paulo (SP) - Pari 3. Mercado imobiliário - São Paulo (SP) - Pari I.Título 
Nome: Pacca, Penha Elizabeth Arantes Ceribelli

Título: A estagnação urbana como parte da metrópole paulistana do século XXI - o caso do Pari

Tese apresentada à Faculdade de Arquitetura e Urbanismo da Universidade de São Paulo como parte dos requisitos necessários à obtenção do título de Doutor em Planejamento Urbano.

Aprovado em:

\section{Banca Examinadora}

Prof. Dr. instituição

Julgamento Assinatura

Prof. Dr. instituição

Julgamento Assinatura

Prof. Dr. instituição

Julgamento Assinatura

Prof. Dr. instituição Julgamento Assinatura

Prof. Dr. instituição Julgamento Assinatura 
À memória de meu pai 


\section{Agradecimentos}

Ao meu orientador prof. Dr. Flávio Villaça, que com paciência e generosidade fez uso de sua experiência e autoridade intelectual para me questionar, testar, propor, pressionar, sempre com o claro propósito de melhorar meu trabalho.

À Odette, que muitas vezes me ouviu e opinou magnanimamente sobre minhas dúvidas e inseguranças.

Aos meus amigos Ester e Hamilcar, que me incentivaram desde as minhas primeiras intenções sobre o trabalho até o fim.

Aos meus colegas da SEMPLA (SMDU): Benê, pelos cálculos infindáveis dos valores venais; Liane, pela eficiência ao atender meus pedidos de mapas; Mary Rai, Akinori, Elza, e demais colegas.

Ao Luís, por ter me acompanhado ao Pari tantas vezes para fotografar e me ajudar no Excel e Photoshop.

À Lia, da CDHU, que me forneceu dados sobre a atuação da Companhia na área.

Ao grupo de estudo formado por Ângela, Bia, Denise, Diego, Fernanda, Marinho, Marisa, Serginho e, sobretudo, Silvana, que me incentivou e levou em conta minhas preocupações.

À Aida, que ouviu meus tormentos e me convenceu da importância de dar um passo de cada vez.

À Mirtes, que revisou os textos com zelo, eficiência e intenção de contribuir sempre.

Aos estagiários Victor e Marcel, que me socorreram sempre que foi preciso.

Ao pessoal do gabinete do Jamil, que me aturou durante minhas crises, sobretudo Elísea, que sempre me salvou quando o computador não queria obedecer. 
Aos moradores e trabalhadores do Pari, que atenciosamente aceitaram conversar e me dar entrevistas. Entre eles, Rogério e seus pais (Pedro e Wilma Alves), Sr. André Kim e He Nem, Sra. Odila, Farmacêutico, Cícero, Sra. Vitória, Sra. Concetta, Iara, Sr. Luís Carlos, Lauro, Sr. Ronaldo, Sra. Olga, Sra. Favorita, Sra. Neide, Sr. Albano, Bia, Clayton, Sra. Zilda.

Ao Daniel, pelo apoio.

Ao Mahler, que fielmente esperava chegar ao meu limite de cada dia para dar sua voltinha.

À Lu, pela paciência nos meus momentos de angústia e desespero diante do trabalho. 
Apenas conhecemos uma ciência, a da história. Esta pode ser examinada sob dois aspectos: podemos dividi-la em História da natureza e história dos homens. Porém, estes dois aspectos não são separáveis, enquanto existirem homens, a sua história e a da sua natureza condicionar-se-ão reciprocamente. A história da natureza, aquilo que se designa por ciência da natureza, não nos interessa aqui; pelo contrário, é-nos necessário analisar em pormenor a história dos homens, pois, com efeito, quase toda ideologia se reduz a uma falsa concepção dessa história ou ao puro e simples abstrair dela. A própria ideologia é somente um dos aspectos dessa história.

As premissas de que partimos não constituem bases arbitrárias, nem dogmas, são antes bases reais de que só é possível abstrair no âmbito da imaginação. As nossas premissas são os indivíduos reais, a sua ação e as suas condições materiais de existência, quer se trate daquelas que encontrou já elaboradas aquando do seu aparecimento quer das que ele próprio criou. Estas bases são, portanto verificáveis por vias puramente empíricas (MARX e ENGELS, A ideologia alemã, vl, $\mathrm{s} / \mathrm{d}: 18)$. 


\title{
Resumo
}

O trabalho procura compreender o processo de estagnação urbana do distrito do Pari, um fenômeno que ocorre em determinadas áreas da metrópole como uma forma de criarem fronteiras de expansão ao capital imobiliário. Para compreender como esse processo ocorreu no distrito do Pari foi analisada a história da formação geográfica do bairro, a história social e demográfica, a história da atividade imobiliária e econômica e a história da Política pública do espaço. O processo ocorrido no Pari mostrou que o distrito concentra diversas atividades, usos, estrutura e população que, na verdade, podem ser considerados estagnados. Mas, mais importante do que a estagnação, é o fato que a sociedade considera essas atividades, usos, estrutura e população com desprezo e isso é uma forma ideológica que traz este conceito, uma vez que é associado com as classes mais pobres.

Palavras chaves: Pari, estagnação urbana, metrópole, bairro, história; mercado imobiliário; propriedade imobiliária, uso do solo, área central, política urbana, cotidiano, ideologia. Key words:

\begin{abstract}
This thesis seeks the understanding the process of urban stagnation that took place in the District of Pari, São Paulo, Brazil. Urban stagnation is understood as a process which occurs in certain areas of a metropolis as a means of establishing barriers for the expansion of real estate capital. For the purpose of understanding how this process has occurred in that district it is analyzed its demographic, geographic, urban-spatial, economic, social and governmental history. Similarities and differences between different central districts of São Paulo are studied in order to understand the process Pari has undergone. It was shown that the district concentrates several activities, land uses, structures and population which, in fact, may be considered stagnant, but more important than that is the fact that society as a
\end{abstract}


whole looks upon such activities, population, structures and land uses, with scorn and that stagnation is an ideological way of conveying that contempt, since they are associated with lower social classes.

Key words:Pari, urban stagnation, metropolis, neighborhood, history; real estate market; immovable property, land use, central area, urban policy, daily life, ideology. 


\section{Lista de Mapas}

Mapa 1 - Localização do distrito do Pari no MSP.........................16

Mapa 2 - Área central do MSP...................................... 38

Mapa 3 - Relevo do distrito do Pari..................................... 39

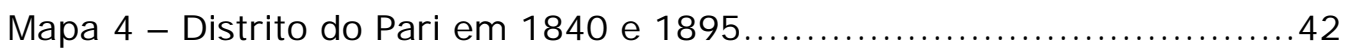

Mapa 5 - 1890 - Planta da capital do estado SP, Jules Martin..............43

Mapa 6 - 1913 - Distrito do Pari, MSP ................................ 44

Mapa 7 - 1924 - Município de São Paulo..................................45

Mapa 8 - 1930 - Município de São Paulo..................................46

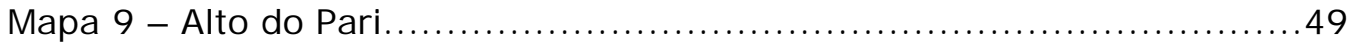

Mapa 10 - Os primeiros loteamentos do distrito do Pari....................50

Mapa 11 - Homicídios dolosos - MSP................................. 65

Mapa 12 - Uso do solo - distrito do Pari - 2006........................ 77

Mapa 13 - Uso do solo - distrito do Pari - 1976.......................... 78

Mapa 14 - Quadras 91, 96, 98, 99 do setor 18 e quadras 101, 103 e 105

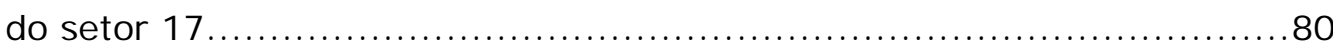

Mapa 15 - Áreas públicas.......................................... 81

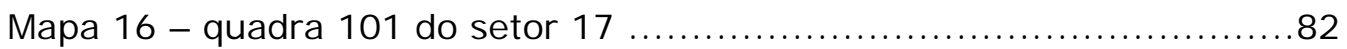

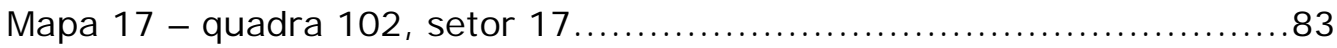

Mapa 18 - Centro comercial do distrito do Pari.............................96

Mapa 19 - quadras de áreas institucionais..............................101

Mapa 20 - Estação Armênia.............................................110

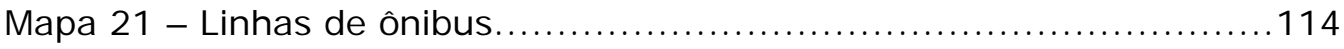

Mapa 22 - Limites da expansão de legalização de Terras no MSP..........123

Mapa 23 - Número de proprietários de coreanos.........................147

Mapa 24 - Número de proprietários de portugueses.....................149

Mapa 25 - Número de proprietários de italianos......................... 150

Mapa 26 - Número de proprietários de árabes..........................152

Mapa 27 - Número de proprietários de outros............................ 154

Mapa 28 - Distrito do Pari em 1942 destacando as várzeas do rio Tietê..159

Mapa 29 - Entidades Religiosas..................................... 161

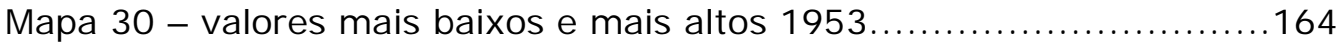




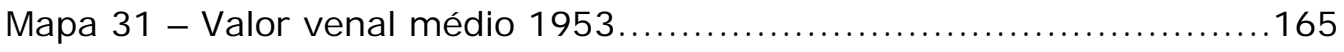

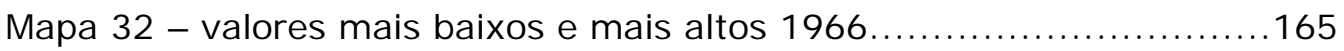

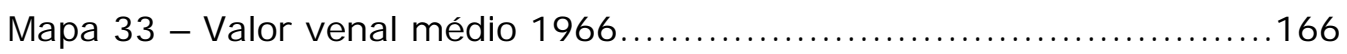

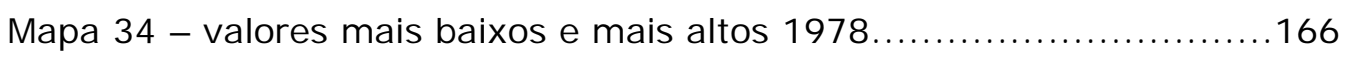

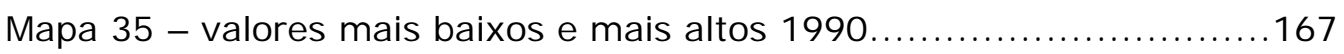

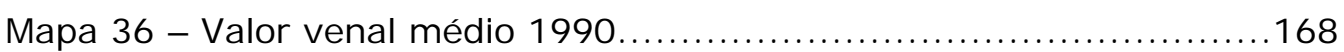

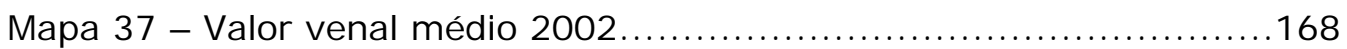

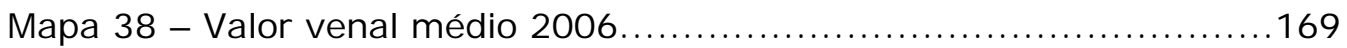

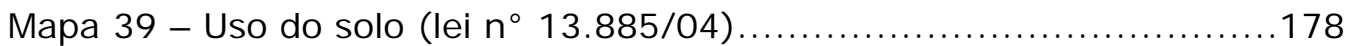

Mapa 40 - Os dois Zoneamentos....................................... 179

Mapa 41 - Rede Estrutural hídrica.................................... 181

Mapa 42 - Rede estrutural de transporte público.........................182

Mapa 43 - Sistema viário estrutural.................................... 183

Mapa 44 - Desenvolvimento urbano.................................... 184

Mapa 45 - Município de São Paulo com os principais elementos da estrutura

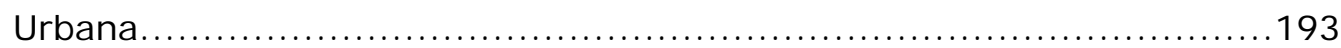

Mapa 46 - Área Central........................................... 208 


\section{Lista de Fotos}

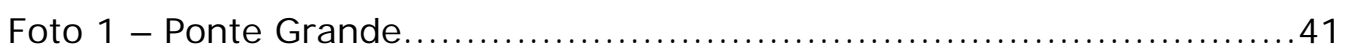

Foto 2 - 1940 - Distrito do Pari, voo VASP...........................47

Foto 3 - 1952 - distrito do Pari, voo VASP............................ 48

Foto 4 - - Rua Guidemar $L$ alto do Pari................................49

Foto 5 - Rua Sacramento, alto do Pari................................. 51

Foto 6 - Rua Vidal Negreiros, cortiços...................................52

Foto 7 - Igreja Santo Antonio.......................................... 55

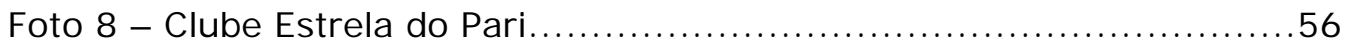

Foto 9 - Igreja Presbiteriana e clínica de acupuntura......................61

Foto 10 - Praça Kantuta e Shopping Pari.................................63

Foto 11 - Fábrica de Bolachas Bela Vista................................ 79

Foto 12 - Restaurante Galinhada do Bahia.............................. 80

Foto 13 - Cortiços Ruas Canindé e Vidal Negreiros........................84

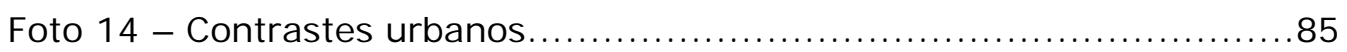

Foto 15 - Imóvel abandonado....................................... 85

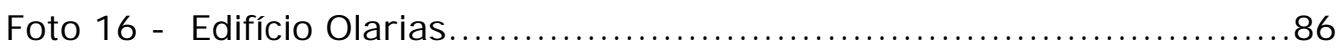

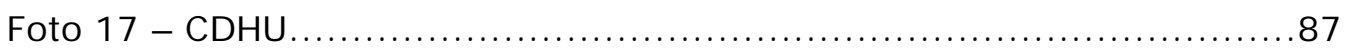

Foto 18 - Residências de padrão mais alto.............................. 88

Foto 19 - Cortiços.................................................... 91

Foto 20 - Favela do bairro.......................................... 92

Foto 21 - Metalúrgica e Panex......................................... 94

Foto 22 - Rua Silva Telles.......................................... 97

Foto 23 - Shopping D e shopping Pari................................... 97

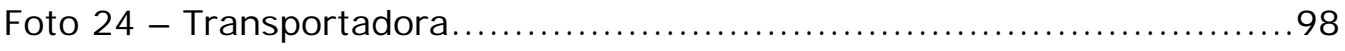

Foto 25 - Bares.................................................... 99

Foto 26 - Postos de gasolina......................................... 99

Foto 27 - Portuguesa de Desportes e Polícia Militar....................... 100

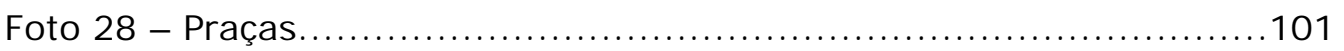

Foto 29 - Biblioteca Municipal Adelpha Figueiredo........................104

Foto 30 - Universidade São Francisco e Delegacia de Polícia.................104

Foto 31 - Igrejas Presbiterianas coreanas..............................147

Foto 32 - Casas enfileiradas e indústria ao fundo..........................151 


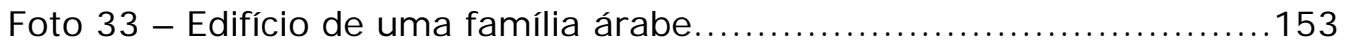

Foto 34 - Edifício com 70\% das unidades em nome de imobiliárias.........157

Foto 35 - Área comercial do Pari....................................... 158

Foto 36 - Igreja Nossa Senhora aparecida e morro do Pari.................181 


\section{Lista de Tabelas}

Tabela 1 - Domicílio segundo s condição de ocupação (\%) MSP...............36

Tabela 2 - População e Taxa de Crescimento 1950 a $2000 \ldots \ldots \ldots \ldots \ldots \ldots . \ldots 67$

Tabela 3 - Renda dos responsáveis..................................69

Tabela 4 - População residente por faixa etária...........................69

Tabela 5 - Índice de envelhecimento por sexo.........................70

Tabela 6 - Condição das Pessoas Residentes.............................71

Tabela 7 - Faixa etária dos responsáveis................................. 71

Tabela 8 - Alfabetização dos Responsáveis pelo domicílio segundo sexo....72

Tabela 9 - Estabelecimentos e empregos formais........................... 74

Tabela 10 - Uso do Solo, distrito do Pari, 2006...........................76

Tabela 11 - Domicílio por Tipo........................................... 86

Tabela 12 - Quantidade de imóveis pessoa física.........................142

Tabela 13 - Quantidade de imóveis de proprietários c/ mais de 2 imóv...143

Tabela 14 - Domicílios por condição de ocupação - 2000..................144

Tabela 15 - Proprietários por nacionalidade............................ 145

Tabela 16 - Proprietários pessoa jurídica............................... 155

Tabela 17 - Entidades religiosas..................................... 161

Tabela 18 - Lançamentos residenciais - 1992 a $2000 \ldots \ldots \ldots \ldots \ldots \ldots \ldots . . . \ldots 175$

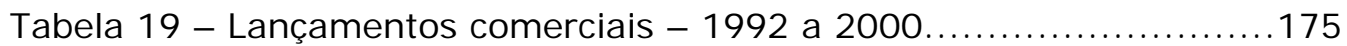

Tabela 20 - Dados gerais por zona de Pesquisa OD - 2007..............217

Tabela 21 - Comparação das histórias dos bairros centrais................227

Tabela 22 - Equipamentos públicos - distritos das áreas centrais ........229

Tabela 23 - Terrenos Vagos/ contaminados / cobertura vegetal...........230

Tabela 24 - Taxa de alfabetização distritos área central - 208............230

Tabela 25 - Área construída - TPCL - 2007/2001/1991..................232

Tabela 26 - Domicílios por faixa de rendimento.........................233 


\section{Sumário}

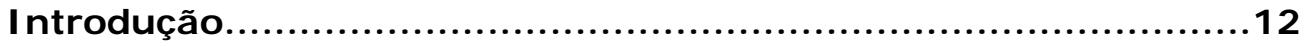

1. O conceito de estagnação urbana.......................................17

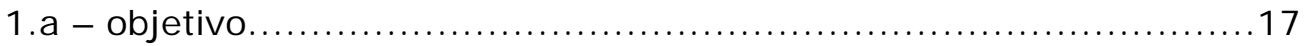

1.b - A Estagnação na economia........................................ 19

1.c - A estagnação na imprensa........................................21

1.d - A estagnação nos textos acadêmicos...............................27

1.e - O conceito de estagnação urbana................................31

2. A estagnação no distrito do Pari: uma investigação.................33

2.a. A história da formação do bairro....................................33

I - O bairro e o distrito .............................................. 33

II - A história das transformações do bairro............................ 37

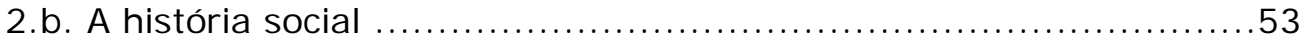

I - Tradições.............................................................. 53

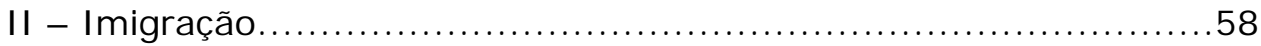

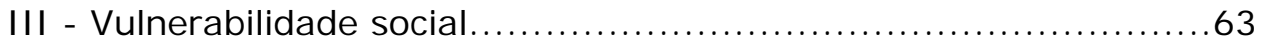

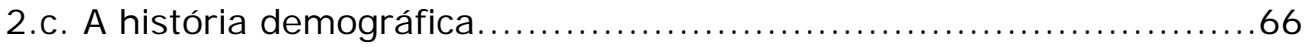

I - Demografia..................................................66

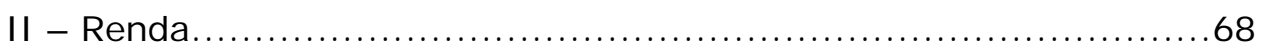

III - Faixas etárias..............................................69

IV - Alfabetização.................................................. 71

2.d- A História da atividade econômica................................. 72

2.e. A História da ocupação urbana ..................................... 74

I - Residencial..................................................... 86

Cortiço

Favela

II - não residencial.

Indústria

Comércio

Uso Institucional 
A diversidade de uso do distrito

III - Infra-estrutura e Transporte.................................. 108

2.f. A História da atividade imobiliária...............................116

I - Introdução.................................................. 116

II - A renda da terra............................................ 130

III - A propriedade imobiliária..................................... 139

Propriedade Pessoa Física

Propriedade Pessoa J urídica

IV - O preço da terra.................................................. 162

V - Lançamentos imobiliários.....................................172

2. g - História da Ação do Poder Público sobre o Espaço..................176

I - Legislação de Uso e Ocupação do solo..............................177

II - Investimentos públicos........................................... 185

3. A estagnação do Pari e a estrutura urbana..........................187

3. a - A estagnação na estrutura urbana paulistana.....................187

3.b - Os bairros centrais e a estrutura da metrópole...................207

3.c - Os bairros centrais........................................................ 216

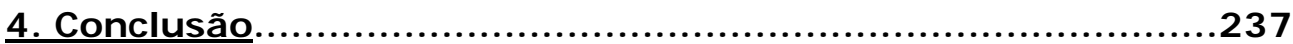

4.a - Compreendendo a estagnação do Pari...........................237

5. Referências bibliográficas...............................................244

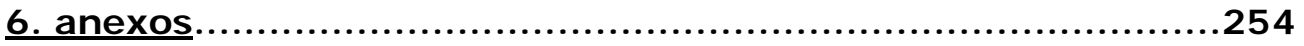




\section{I ntrodução}

O objetivo desta tese é procurar entender os fatores que levaram à estagnação urbana um bairro da cidade de São Paulo. A metrópole paulistana é cenário de diferentes processos de desenvolvimento, com áreas que não despertam o interesse do mercado imobiliário e outras que são disputadas por ele. Diante da carência de ação do Estado e da imobilidade da população no espaço metropolitano, procuramos investigar uma área onde aparentemente não houve grandes alterações no decorrer dos últimos 50 anos, período de significativa importância no desenvolvimento e na fixação do capitalismo no Brasil. A área escolhida foi o distrito do Pari.

No capítulo 1, conceituamos o que entendemos por estagnação urbana. Como não foi encontrada nenhuma definição de estagnação urbana em pesquisa na área do urbanismo, foi preciso construir a definição para atingir o objetivo do trabalho. Recorremos, também, à conceituação de estagnação em outras disciplinas para poder balizar nossa conceituação.

No capítulo 2, justificamos a escolha da área e nos propusemos a investigar o distrito sob o ângulo de sua formação histórica e social. A pesquisa recolheu um material empírico e foi preciso, também, um estudo teórico para alcançar o objetivo proposto. Investigar a história do Pari documentada em bibliotecas ou arquivos foi quase impossível. Os relatos sobre os bairros operários na cidade de São Paulo são sempre do Brás e da Mooca ou até do Belenzinho em razão do atrativo exercido pela vila operária Maria Zélia, lá localizada. O Pari não teve a atenção merecida nas pesquisas urbanísticas sobre a cidade. Por isso, esse bairro despertou-nos uma curiosidade particular e foi necessário fazer a pesquisa empírica.

O Pari nasceu como um bairro operário e se desenvolveu no começo do século XX até a década de 1950, sofrendo uma decadência paulatina no transcorrer dos anos seguintes.

O distrito do Pari se desenvolveu em função da implantação de diversas indústrias no bairro e na sua proximidade, principalmente na região 
do Brás. Foram indústrias diversificadas, ali implantadas, com a predominância de fabricação de artigos domésticos e alimentícios e, mais recentemente, confecções. Por isso, muitos operários escolheram o Pari para morar. Esses operários eram majoritariamente imigrantes recém-chegados ao país à procura de emprego e de uma nova vida. Assim, a quantidade de imigrantes e de descendentes é visivelmente clara quando se caminha por suas ruas.

Por ser um distrito com muitos usos diferentes - comércio atacadista e varejista, diversidade nos tipos de indústrias, e habitação de todos os padrões -, o Pari acolhe também pessoas com diferentes interesses, classes sociais e idades.

Esse capítulo se propõe a conhecer essa área da cidade que aparentemente estagnou em comparação a outras inseridas no universo imaginário da população como a cidade contemporânea, ou "cidade global".

O Pari pode ser considerado um bairro onde não há segregação intrabairro. Não há separação social nem isolamento de usos ou segregação residencial. Existem moradores paupérrimos e de classe média, os vários níveis sociais convivendo entre si. Os bairros de classe média fora do quadrante sudoeste, ou seja, excluídos do mercado imobiliário, tiveram um desenvolvimento mais lento e sua inserção na metrópole foi desorganizada. Levando em conta que o domínio da produção do espaço urbano se dá por iniciativa do mercado imobiliário, concluímos que não houve interesse no controle desses espaços por parte da classe dominante e do poder público.

A investigação sobre valor da terra urbana, valor imobiliário, promoção imobiliária, indústria da construção foi realizada no espaço do bairro. Já que a cidade é o lugar da acumulação de grande parte da indústria da construção civil, tentamos investigar a causa da falta de interesse pelo bairro.

No capítulo 3, abordamos os bairros centrais, suas semelhanças e diferenças de formação e condições atuais. Essa abordagem foi sucinta, pois não era objetivo deste trabalho abranger uma discussão profunda sobre o centro da metrópole. Nosso propósito foi apenas o de descerrar o panorama 
onde se situa o distrito do Pari para embasar a avaliação sobre sua estagnação.

Por pressão do movimento "Viva o Centro", os distritos do Pari e do Brás foram deslocados a leste, integrando a subprefeitura da Mooca. Foi no mínimo esdrúxula essa opção, porque, desde a delimitação administrativa efetuada no município, o Pari e o Brás pertenciam ao Centro, à Administração Municipal da Sé. Neste trabalho tratamos o Pari como um distrito da área central.

No capítulo 4, compreendemos como a estagnação do Pari é revelada ou como ela é interpretada.

Diante da ineficiência do Planejamento Urbano como indutor ou estruturador do espaço da cidade ou de um bairro, e também por não acreditarmos nesse Estado como promotor do fim das desigualdades sociais, pois cada vez mais essa situação se aprofunda, propusemo-nos a conhecer a prática dos cidadãos no território e suas ações por meio de entrevistas a moradores, frequentadores e trabalhadores do bairro, para compreender aspectos da sociedade paulistana e seu espaço.

A intensidade da reestruturação do espaço metropolitano impulsionada pelo processo de crescimento e desenvolvimento urbano e aliada à crise do capitalismo apresenta um reflexo na organização específica da produção e reprodução, do consumo e circulação, modificando a configuração do ambiente construído.

O Estado sente necessidade do Planejamento Urbano para poder dominar a sociedade em nome do saber, da técnica. Mas esse planejamento está submetido aos interesses do mercado imobiliário. Se este, por alguma razão, não se interessa por determinada área, o Estado não investirá nela; e, se uma área é carente de investimento público, não despertará o interesse do mercado. A população de algumas áreas esquecidas pelo poder público vive mais "livre", menos presa à espera de uma iminente valorização do espaço. O mercado e o Estado atravancam a ação da população. O Planejamento torna-se ideologia. A ação do poder público conjuntamente com as determinações da classe dominante constrói o espaço. 
O distrito do Pari está localizado entre as várzeas dos rios Tamanduateí e Tietê e a estrada de ferro RFFSA, antiga São Paulo-Rio (MAPA 1). A malha urbana do Pari consolidou-se em 1960. Originalmente um núcleo rural, foi-se transformando em área de ocupação com atividades industrial e comercial, com predomínio do setor de confecção, originado no Brás. Para acolher os trabalhadores dessas atividades, o bairro foi escolhido como o principal local de moradia, sobretudo dos de renda mais baixa. Apresenta hoje grande extensão de área institucional, já consolidada, e uma elevada oferta de equipamentos públicos. A maior parte de suas quadras tem ocupação de baixa densidade, com lotes individuais que aparentemente preservam a divisão fundiária original; conta também com a presença de um conjunto de edificações com galpões e áreas remanescentes de pátios que apoiavam a antiga estrutura ferroviária. A modalidade de habitação coletiva é historicamente consolidada nessa região, devido à iniciativa de proprietários em estabelecer em seus imóveis esse tipo de exploração e ao processo de deterioração de moradias individuais mal conservadas. O Pari apresenta um quadro típico de transição de usos, com um extenso parque imobiliário estagnado e com infraestrutura subutilizada. 


\section{MAPA 1 - Localização do distrito do Pari no MSP}

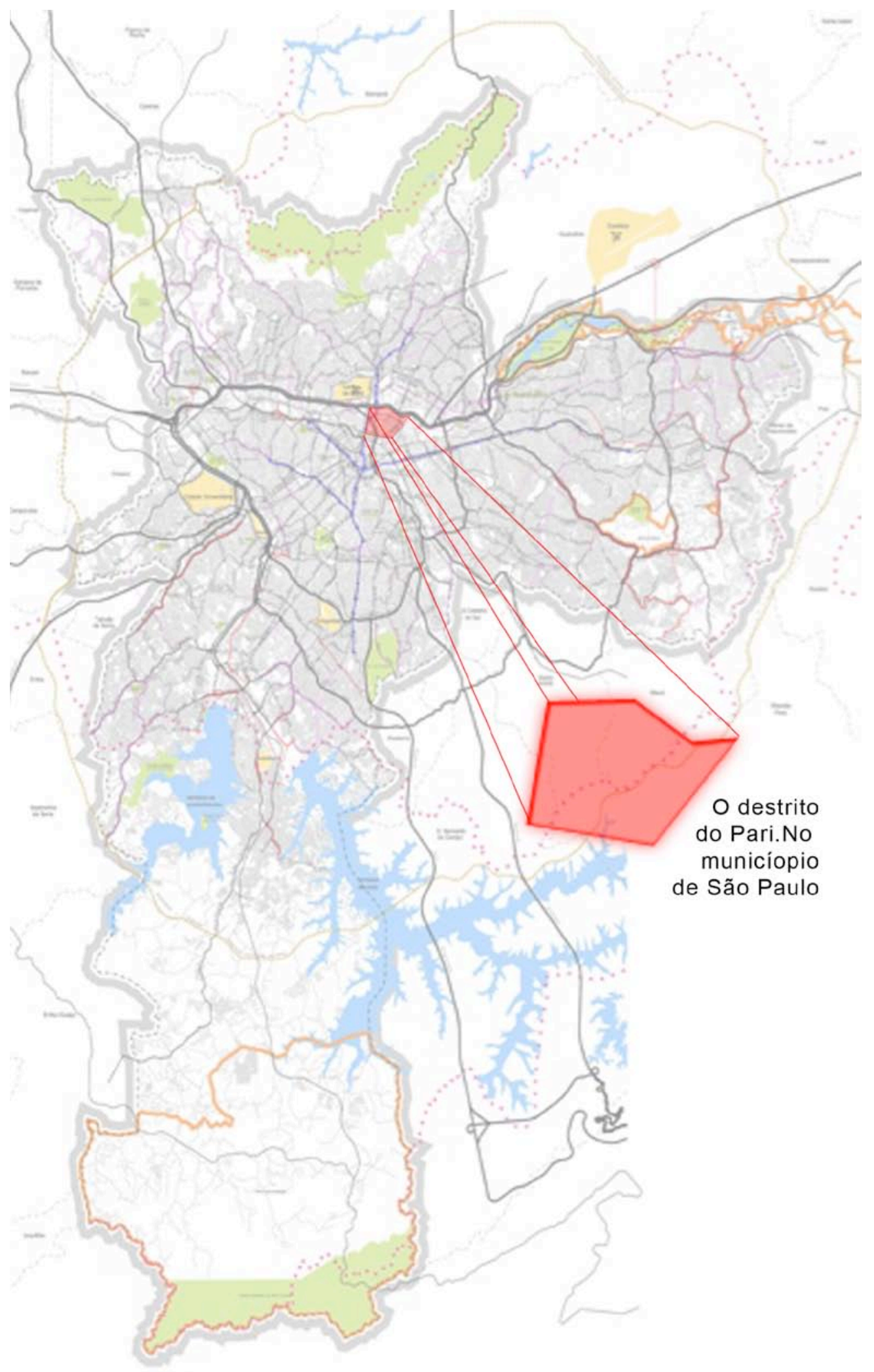




\section{O conceito de estagnação urbana.}

\section{1.a. Objetivo}

O objetivo desta tese é entender a estagnação urbana do distrito do Pari, analisando-o como uma singularidade dentro da cidade de São Paulo e procurando compreender a metrópole do ponto de vista do processo urbano. Na pesquisa, a estagnação urbana não é enfocada como um fato em si, mas como uma tese a ser provada (ou não), advinda da análise, da reflexão produzida pela reestruturação do capitalismo na metrópole paulistana.

Há diversos estudos sobre a produção do espaço em São Paulo, tendo em vista o capitalismo contemporâneo, todos eles abordando áreas produzidas e/ou ocupadas pelas classes dominantes. Dentre estes destacam-se os de Fix, Nobre, Whitaker, Vainer, Wilderode ${ }^{1}$. Esses autores analisam como a reestruturação produtiva ocorreu na cidade, ressaltando a área que consideram como modelo desse processo. Tal área é constituída essencialmente pela Marginal Pinheiros e pelas avenidas Luís Carlos Berrini/Chukri Zaidan.

Entretanto, pouco ou quase nada tem sido estudado sobre a forma como esse mesmo capitalismo tem produzido áreas que podem ser consideradas como opostas a essas. São as chamadas "áreas estagnadas" da cidade, que, nas últimas décadas, pouco ou muito lentamente se modificaram do ponto de vista econômico, imobiliário, demográfico ou social. Pelo menos esse parece ser o pensamento dominante. Tais áreas foram e/ou são ocupadas por população de renda média ou mais baixa e por atividades econômicas por elas conduzidas ou para elas voltadas. Entre essas áreas destacam-se o Brás, o Belenzinho, a Luz, o Bom Retiro e o Pari.

\footnotetext{
${ }^{1}$ Fix, Mariana (2007) - São Paulo cidade Global - Boitempo Editorial, SP; Ferreira, João Sette Whitaker (2007) - O mito da Cidade Global - Editora Vozes, Petrópolis; Nobre, Eduardo (2000) Reestruturação econômica e território: expansão recente do terciário na Marginal do rio Pinheiros tese de doutorado, Fauusp,SP; Vainer, Carlos (2000)- Os liberais fazem planejamento urbano? - In: Arantes, O. Maricato, E. Vainer, C. - O pensamento único das cidades: desmanchando consensos, Vozes, Petrópoles; e Wilderode, D. - Cidade à venda: interpretação do processo imobiliário - tese de doutorado, Fauusp, SP.
} 
A estagnação, nessas áreas, é fruto da segregação socioespacial produzida pelo mesmo processo de reestruturação da metrópole que promove o desenvolvimento de outras áreas, áreas que receberam grandes investimentos, tanto públicos como privados, e tiveram um desenvolvimento excepcional em relação a todo o resto da metrópole. O que resultou desses investimentos é tratado na mídia em geral e no pensamento dominante como a manifestação de "cidade-global", termo que destaca, nesses espaços, o ritmo e a intensidade de usos de alto padrão, de tecnologia avançada, e a consequente produção, no espaço urbano, de um cenário do capitalismo flexível e globalizado. Esse processo revela também o lugar de nosso objeto de estudo, o distrito do Pari.

Pretendemos mostrar o outro lado da moeda, ou seja, analisar, dentro da ótica da reestruturação do espaço e da economia, de que modo se comportam os espaços "abandonados" pelo mercado e pelo Poder Público. A nossa inquietação com o Pari justifica-se por entendermos que o Poder Público age em nome de uma estratégia: abandonar determinadas áreas com acessibilidade para toda a metrópole com o objetivo de formar uma reserva de valor para o mercado imobiliário.

Este trabalho adota e adapta para o caso urbano o conceito leigo de estagnação. Segundo o dicionário Houaiss, "estagnação" significa: falta de progresso, de movimento, de atividade, paralisação". (HOUAISS, 2001:1245)

A palavra "estagnação" é reconhecida comumente como o estado imóvel, a paralisia, ou uma mudança em sentido inverso ao do movimento, ou um movimento mais lento. Este trabalho não discute nem questiona o uso da palavra "estagnação", mas a aceita em seu sentido mais amplo. E a entende, em princípio, como o processo por meio do qual certas áreas constroem um movimento mais lento que outras, ou até permanecem imobilizadas nessa evolução da produção do espaço urbano.

A estagnação do Pari - onde se verifica um descompasso em relação ao movimento de outras partes da cidade - não é um fenômeno isolado, mas vinculado à produção do espaço metropolitano e, portanto, à sua reestruturação, que tem, como um de seus produtos, a segregação socioespacial, da qual a estagnação é uma manifestação. Podemos tomar, aqui, o singular - o distrito - como um caso universal. 


\section{1.b. A estagnação na economia}

O significado da palavra "estagnação" está estreitamente relacionada à disciplina da Economia. Há sentidos específicos da palavra "estagnação" dentro do contexto de cada disciplina, mas na Economia, onde é largamente empregada e mais facilmente compreendida, sua definição pode ser:

Situação em que o produto nacional (ou produto per capita) não mantém nível de crescimento à altura do potencial econômico do país (SANDRONI, 2001:221).

E a interpretação do fenômeno da estagnação econômica indica que:

Segundo os economistas da escola keynesiana, a tendência à estagnação é uma das características do capitalismo, caso a economia concorrencial seja relegada a seus mecanismos naturais (SANDRONI, 2001: 221).

Estagnação, então, está ligada a falta, a ausência de movimento e, como afirma a escola keynesiana, seria parte inerente do capitalismo. A definição econômica se aproxima muito do sentido de estagnação do desenvolvimento de um determinado lugar, pois podemos fazer uma analogia com a cidade. O bairro estagnado não mantém o nível de crescimento $^{2}$ à altura do potencial da metrópole - a demanda por desenvolvimento da área fica abaixo da expectativa da média geral do município. A tendência à estagnação de alguns bairros é uma característica da cidade capitalista e, para combatê-la, o Estado teria de intervir por meio do Planejamento Urbano. Na cidade capitalista, o movimento das atividades urbanas depende intrinsecamente da economia nacional, regional e municipal. É uma relação nitidamente visível e, em

${ }^{2}$ Crescimento: de emprego, de atividades comerciais, industriais ou de serviço; além de crescimento demográfico, crescimento de infra-estrutura ou melhoria na qualidade ambiental e de vida. 
tempos de crise ou de grandes investimentos, pode-se perceber essa realidade com mais clareza.

Ao fazer ainda uma correlação da palavra "estagnação" com outras, inerentes ao sentido de espaço, como movimento, segregação, estrutura, percebe-se com mais nitidez como a estagnação se revela. 0 movimento no e do espaço é intrínseco ao seu processo. A cidade está em contínuo movimento e as mudanças dessa dinâmica - o desenvolvimento ou a ausência de crescimento - se manifestam como estagnação de algumas partes e como desenvolvimento de outras, dentro de um mesmo processo.

Para o dicionário de Filosofia, a definição de "movimento" é: Em geral, mudança ou processo de qualquer espécie (Abbagnano, 1999: 686). Observando o processo de um bairro e da metrópole, vê-se o movimento como alteração, diminuição ou ausência de transformação. Aquilo que aciona o movimento - o motor que dinamiza um bairro - é o investimento em obras, transportes, projetos de intervenção e principalmente o interesse da classe dominante nos negócios do bairro. Se não há interesse, ocorre o abandono e o movimento é brecado. Se a área é alvo de especulação imobiliária futura ou imediata, isso pode disparar a venda de imóveis; por outro lado, esse movimento pode fazer com que os moradores sejam obrigados a abandoná-los. O Poder Público só investe em uma área se ela pode trazer um retorno seguro; assim, um bairro com baixo retorno é menosprezado e considerado estagnado e sofre uma perda de suas atividades econômicas. Sua disposição em desenvolver-se torna-se frágil, o que provoca um descompasso em sua relação com a metrópole, mesmo que a vivência intrabairro possa trazer satisfação a seus moradores e até preencha suas expectativas quanto à fruição de um espaço tranquilo, do qual mais facilmente estarão ausentes a violência, a marginalidade, o congestionamento do trânsito etc. vantagens essas, no entanto, que pode não existir do ponto de vista do mercado imobiliário, podendo levar ao afastamento dos empresários e dos incorporadores do bairro. 


\section{1.c. A estagnação na imprensa}

Para melhor compreensão do significado da palavra "estagnação" e para a construção do conceito de "estagnação urbana" fizemos uma pesquisa nos jornais O Estado de São Paulo, Folha de São Paulo, Gazeta Mercantil e na Internet. O resultado mostrou que a palavra "estagnação" sempre está relacionada ao ritmo de crescimento ou à queda dos preços dos aluguéis e/ou dos imóveis; à perda de confiança por parte dos investidores; às expectativas da taxa de desemprego; à desaceleração da economia conjugada à fraqueza do setor imobiliário. Ou seja, ela tem uma conotação basicamente econômica.

$\mathrm{Na}$ pesquisa verificamos que a palavra "estagnação" em seu sentido leigo foi emprestada da economia, já que é bastante comum encontrá-la em revistas especializadas ou cadernos de economia dos jornais diários. Na Internet, em sites de revistas antigas, encontram-se artigos sobre estagnação econômica - a expressão não é definida, aparece como um termo já previamente compreendido.

No jornal Folha de São Paulo de 20/03/09, com o título "Até que ponto o trabalho é prioridade na sua vida?", um analista de Recursos Humanos sustenta que, no âmbito profissional, se o indivíduo perde oportunidades de alcançar metas ou de se aperfeiçoar na empresa, isso pode acarretar sua estagnação. O sentido que o analista atribuiu à palavra "estagnação" foi de imobilidade, ou mesmo de fracasso.

Outro artigo no mesmo jornal, do dia 19/03/2009, sobre educação, afirmava "a preocupação diante de uma estagnação no alicerce de toda a educação da primeira a quarta séries em razão dos resultados apresentados dos alunos na qual a média de notas da rede não avançou". Ou seja, dava à palavra "estagnação" um sentido negativo, de retrocesso.

Consideramos significativas ainda duas outras notícias, dos dias 16 e 12/03/09, que tratavam de economia. A primeira mostrava como o setor da construção, com uma queda de $3 \%$ no primeiro trimestre de 2009, também havia sido afetado pela crise, enquanto apontava estagnação no comércio, nos serviços e nos transportes públicos. Na segunda, o presidente do IPEA (Instituto de Pesquisa Econômica Aplicada) analisava a queda do crescimento brasileiro, afirmando que os 
impactos da estagnação se refletiam no aumento que a taxa de juros acarreta sobre a economia.

O sentido mais comum da palavra "estagnação" está sempre ligado à ideia de declínio, recuo, involução. As notícias nas quais a palavra aparece sempre dizem respeito ao mau desempenho da economia, à violência, ao fracasso pessoal ou à decadência do desenvolvimento de um setor.

A pesquisa realizada no jornal O Estado de São Paulo não se mostrou diferente. Todas as notícias que abordavam a estagnação se referiam à economia: "A OCDE alerta que Mercosul é fraco e Brasil precisa de reformas e as medidas protecionistas poderiam levar à estagnação de Paraguai e Uruguai"; "No Japão, houve uma grave crise após o estouro da bolha imobiliária, e a estagnação durou muitos anos"; "Estagnação é dada como certa"; "A indústria vai apresentar estagnação ou até retração em 2009"; "Os números indicam, na melhor das hipóteses, uma estagnação do Brasil em 2009"; "...Lula também argumenta que, ao chegar ao governo, encontrou 'profundos preconceitos' que poderiam levar o País à estagnação, como a avaliação de que não era possível crescer sem ameaçar a estabilidade econômica".

Percebemos, em todos os artigos, que não há uma preocupação em definir a palvra "estagnação". Ela é usada com um sentido preconcebido, familiar à compreensão do senso comum ${ }^{3}$. O presente trabalho, porém, pretende explorar um significado específico para "estagnação urbana".

A expressão "estagnação econômica" é, com frequência, relacionada à política econômica, responsável pela situação da dívida do setor público, pela elevada taxa de juros e pela excessiva carga tributária, como mostra a análise de Kanitz (2004). É assim que a mencionam os diversos artigos. E a manutenção dessa política econômica, que privilegia excessivamente o mercado financeiro, traz o desemprego, a informalidade e as desigualdades sociais, além de consolidar um quadro de estagnação, agravado por frequentes crises financeiras que trazem risco à governabilidade. (PEREIRA, 2004).

\footnotetext{
3 Senso comum - no pensamento moderno, conjunto de opiniões, idéias e concepções que, prevalecendo em um determinado contexto social, se impõem como naturais geralmente sem reflexões ou questionamentos; consenso (HOUAISS, 2001).
} 
Na revista Retrato do Brasil (2003), a reportagem Opinião Brasil intitulada "Como Sair da Estagnação" expõe a opinião de diversos pensadores brasileiros, como Celso furtado, Plínio de Arruda Sampaio Jr., César Benjamim e José Luis Fiori, quanto à estagnação da economia brasileira. As explanações discorrem, sempre, sobre o pequeno crescimento que o Brasil vinha tendo nos últimos anos, apesar de outros países emergentes apresentarem crescimento significativamente maior. A pergunta apresentada aos entrevistados era: "Como sair da estagnação?". No entanto, nenhum expôs seu conceito sobre estagnação, pressupondo que todos conheçam o significado, o conteúdo semântico da palavra.

Plínio de Arruda Sampaio Jr. diz que a estagnação está presente porque

O Brasil abdica do seu projeto nacional e de qualquer pretensão hegemônica em troca do acesso privilegiado ao mercado interno americano, como ocorreu na versão inicial com Japão, Alemanha, Taiwan e Coreia.

Celso Furtado defende que, para sair da estagnação, só a tomada de consciência do povo brasileiro pode trazer transformações:

\footnotetext{
(...) a civilização surgida da revolução industrial europeia conduz inevitavelmente a humanidade a uma dicotomia de ricos e pobres, dicotomia que se manifesta entre países e dentro de cada país de forma pouco ou muito acentuada. Segundo a lógica dessa civilização, somente uma parcela minoritária da humanidade pode alcançar a homogeneidade social ao nível da abundância. A grande maioria dos povos terá que escolher entre a homogeneidade a níveis modestos e um dualismo social de grau maior ou menor". "(...) a história ensina que só a pressão social de baixo para cima é capaz de promover os interesses das classes trabalhadoras, as forças populares devem evitar o equívoco de acreditar em homens providenciais. Não pode haver ilusão. O povo brasileiro não deve esperar nenhuma transformação social que ele não possa conquistar com as próprias mãos.
} 
José Luis Fiori argumenta que a estagnação é um fenômeno intrínseco às economias periféricas:

O Brasil nasceu como apêndice ou periferia do sistema econômico hegemonizado pela Inglaterra. Dos anos 20 a 1930 - Brasil cresceu graças à complementaridade entre sua economia e a economia mundial, sobretudo, à integração do pais com as finanças inglesas. No início de 1990, a vitória americana na Guerra Fria, a nova utopia da globalização e mais uma onda de liquidez internacional criaram as bases materiais e ideológicas da nova virada liberal das elites e do Estado brasileiro. A elite brasileira nunca precisou da incorporação popular para garantir a reprodução e acumulação de sua riqueza patrimonial ou mercantil, feita através dos circulo financeiros internacionais.

César Benjamin sustenta que, para acabar com a estagnação (entendida no artigo como estagnação econômica), torna-se necessário a conquista da independência e a mudança da sociedade:

O sistema econômico internacional é estruturalmente assimétrico. (...) O núcleo do sistema internacional são os espaços que concentram em si dinâmicas da inovação. Eles capturam sucessivamente as posições de comando justamente porque conseguem recriá-las, obtendo dessa forma benefícios extras da divisão internacional do trabalho. (...) $A$ problemática do rompimento da dependência se articula, pois, com a questão mais geral da transição a um novo tipo de sociedade dessa articulação e viabilizá-la politicamente é o nosso desafio. (...) nossos espaços aumentam em períodos em que a hegemonia está em disputa. Descobrir o caminho depende de nossa própria capacidade de colocar importantes mudanças internas na ordem do dia.

Portanto, "estagnação econômica" é já um conceito obscuramente apresentado, não é preciso clareá-lo para se fazer compreender. A expressão tem o mesmo sentido com que aparece na linguagem cotidiana comum, no modo comum de viver, com a qual a sociedade se intercomunica, sem que seja necessário formular sua definição. 
Ao aprofundar a pesquisa na imprensa sobre a palavra "estagnação", atribuindo-Ihe o predicado "urbana", encontramos artigos que remetiam sempre a cidades históricas, vinculando seus processos à decadência econômica ou ao abandono do Poder Público.

Foi constante a relação de "estagnação urbana" à análise de cidades que tiveram seu auge econômico em certo período e depois decaíram. Todos os conteúdos tratavam daquelas que possuem reconhecidamente um patrimônio histórico a preservar, como se vê na análise de Andrade (2008) sobre Itabuna, na Bahia. Ele fala da importância da cidade como polo cacaueiro e a compara à cidade portuária de Ilhéus:

Esta cidade difere em muitos aspectos do centro portuário da zona cacaueira que é Ilhéus. Muito mais jovem que esta, não se arrastou por séculos sob o peso da estagnação urbana e econômica ${ }^{4}$. Surgiu quase ao alvorecer do surto cacaueiro em volta de posto comercial, fundado em 1873, e em pouco mais de três décadas foi elevada à categoria de "cidade". (ANDRADE, 2008)

Pode-se notar que o autor compreende como processos distintos a estagnação econômica e a urbana. É uma atitude comum entre os historiadores recorrer à expressão "estagnação urbana" ao analisarem cidades históricas, destacando a diferenciação em relação a "estagnação econômica". Percebe-se, assim, que eles reconhecem a estagnação urbana como um fato.

A maioria dos artigos encontrados na imprensa sobre estagnação é diretamente ligada ao sentido econômico da palavra. Ao procurar por outros termos que pudessem relacionar a situação de estagnação urbana estritamente com o espaço urbano, foram encontrados expressões como: violência urbana, desvalorização imobiliária, perda de população residente, cortiços. Notícias relacionadas a esses fatos foram encontradas em várias reportagens relatando a situação em que vivem moradores de diversos bairros da periferia de São Paulo e a de alguns casos de violência urbana, em particular nos bairros centrais. Mas em nenhuma reportagem aparecia a expressão "estagnação

\footnotetext{
${ }^{4}$ Grifo da autora
} 
urbana". Por exemplo, na Folha de São Paulo (16/12/2007) o repórter fotográfico Antônio Gaudério fez uma reportagem sobre as condições de trabalho dos bolivianos, particularmente os indocumentados, que vêm a São Paulo para trabalhar em confecções. E em nenhum momento o repórter faz uma mínima análise da relação desses bolivianos com o espaço urbano. Parece que falar sobre a cidade é assunto para especialista, e os especialistas não se interessam por situações urbanas embaraçadas em outras matérias; tratam apenas de questões pontuais. Explica-se, pois, a razão de artigos exclusivamente sobre estagnação econômica.

Outra notícia do jornal Folha de São Paulo (14/07/2004) relacionada à estagnação urbana foi sobre a Operação Urbana JacuPêssego. O título era: "Nova operação urbana deve reverter estagnação econômica da zona leste". Apesar de a procura ter sido por "estagnação urbana", o conteúdo dizia respeito à estagnação econômica:

O programa visa atrair investimentos e gerar empregos na região, sobretudo nos bairros mais pobres, como São Miguel, Itaquera e São Mateus. O objetivo é reverter a atual situação de estagnação econômica da porção leste da cidade, que a transformou em um imenso "bairro-dormitório".

A operação supõe investimentos em infra-estrutura e educação. Segundo a Prefeitura de São Paulo, a Operação Urbana Rio Verde-Jacu deverá atrair empreendimentos industriais, comerciais e de serviços. A ideia é transformar o eixo da Avenida Jacu-Pêssego num novo centro empresarial da cidade, num raio de dois quilômetros e meio a leste e a oeste da via, entre a Rodovia Ayrton Senna e a Avenida Ragueb Choffi.

A pesquisa constatou que o uso da palavra "estagnação" na imprensa está ligado, quase sempre, às questões econômicas. E que, na compreensão leiga, ela se relaciona diretamente à perspectiva econômica e com sentido negativo, para baixo, retroativo. 


\section{1.d. A estagnação nos textos acadêmicos}

Este trabalho apresenta um estudo de como a palavra "estagnação" é utilizada em outras disciplinas.

Nos meios acadêmicos é mais presente, ainda, a associação da palavra "estagnação" à economia. O mais memorável intelectual a tratar sobre a estagnação, no Brasil, foi o economista Celso Furtado. Os ensaios reunidos em Subdesenvolvimento e Estagnação na América Latina ${ }^{5}$ fazem uma incursão sobre os fatores estruturais internos que impedem o desenvolvimento. Para Furtado a estagnação é o reverso do desenvolvimento, e o desenvolvimento só poderá ter êxito se as massas receberem uma orientação ideológica para ter ideias claras. 0 problema revela o lado político da questão, e não define o que é estagnação, mas reitera várias vezes que o desenvolvimento político e econômico só se realizará pela "tomada de consciência", ponto crucial do problema da ideologia e seu papel nos processos de transformação política da América Latina. O livro, de 1966, faz uma análise além da política econômica brasileira, e a palavra "estagnação" se restringe ao sentido econômico, tratado no capítulo 3 - "Fatores estruturais internos que impedem o desenvolvimento" - e no capítulo 4 - "Análise do caso do Brasil" (SCHWARTZMAN, 1966). A palavra "estagnação" parece carregar um sentido essencialmente econômico, e na economia o seu sentido é amplo e multifacetado.

Na verdade, o termo já havia sido usado por economistas americanos, e Paul Sweezy, numa palestra dada no Havard Economics Club em março de 1982, pergunta "Por que estagnação?", e afirma:

No rastro da aguda recessão de 1937 principiou a espalhar-se entre os economistas um debate sobre as causas da estagnação. Os dois mais proeminentes protagonistas foram Alvin Hansen e Joseph Schumpter, os principais economistas da Havard da década de 1930.

Esses economistas definiam estagnação como um estado da economia com algumas mudanças, segundo Hansen:

\footnotetext{
${ }^{5}$ Subdesenvolvimento e Estagnação na América Latina, Rio de Janeiro, Ed. Civilização Brasileira, 1966.
} 
1. O fim da expansão geográfica, por vezes colocada em termos de "fechamento da fronteira", mas interpretadas por Hansen num sentido global mais vasto; 2 . um declínio da taxa de crescimento populacional; e 3. uma tendência da parte das novas tecnologias a serem menos utilizadoras de capital do que em anteriores estágios do desenvolvimento capitalista (SWEEZY,1982).

O problema da estagnação era a grande capacidade do sistema de poupar em vez de investir em crescimento rápido. Mas, depois da Segunda Guerra Mundial, o assunto da estagnação passou para o âmbito das curiosidades históricas, retornando à baila somente na crise da década de 70-80. Atitude prematura, segundo Sweezy, pois ela sempre estará presente entre os ciclos econômicos, que hoje em dia são cada vez mais curtos.

O primeiro texto acadêmico a despertar o interesse para a palavra estagnação, no sentido urbano, foi o texto do prof. Dr. Flávio Villaça, intitulado: "A produção e o uso da imagem do centro da cidade - o caso de São Paulo" (1993), cuja introdução diz:

Este texto aborda aquela que pode talvez ser chamada a parte mais importante de uma cidade: seu centro. Aborda-o enquanto imagem, enquanto texto não verbal. Destaca os processos concretos que vem ocorrendo no centro de São Paulo - seu crescimento, deslocamento, estagnação 6 , deterioração e bipartição - bem como a versão ou a interpretação dada pela classe dominante a esses processos. Mostra então como, a partir dessa interpretação, essa classe produz símbolos, signos e linguagens que procuram veicular mensagens que sirvam a seus interesses, ao mesmo tempo em que destrói aqueles contrários a esses mesmos interesses (VILLAÇA, 1993).

O que percebemos de imediato nessa introdução é a distinção que o autor faz entre estagnação e deterioração. Entendemos deterioração como uma condição física de abandono, de estrago ou de dano visualmente perceptível, enquanto estagnação significa uma ação de agentes combinados e não pontuais, que se traduz, sobretudo, em

\footnotetext{
${ }^{6}$ A palavra foi assinalada pela autora.
} 
desemprego, involução econômica, decadência imobiliária - fatores que se refletem no ambiente urbano, tanto na população como na paisagem. Embora no decorrer do texto o autor não use mais a palavra "estagnação", ela se colocou com uma abrangência mais ampla que a de "deterioração". Para a compreensão do conceito, torna-se necessária essa distinção.

Há outros textos acadêmicos que se utilizam da expressão "estagnação urbana". No entanto, o seu emprego se refere sempre ao centro de cidades históricas do Brasil ou do exterior, e especialmente para analisar os bairros centrais da cidade de São Paulo. É o caso, por exemplo, de textos sobre cidades de Portugal, como Porto, Évora e Santarém. Todos eles dão uma abrangência mais complexa a "estagnação urbana" do que a significação restrita de deterioração física do centro, e sempre destacando a questão do patrimônio associado ao ambiente construído. Como por exemplo:

Após a conquista sueva e, depois visigótica, o Porto, que passara de castrum a civitas, encetou um período de retrocesso e estagnação urbana (FUSTIGANTE, 2004).

Pode-se observar também o texto sobre um bairro central de São Paulo, a Luz, da professora Regina Meyer:

Na década de 90, quando tudo apontava para uma estagnação urbana, importantes investimentos públicos são ali realizados: a reforma e expansão da Pinacoteca do Estado (1998) e a construção da Sala São Paulo, no interior da Estação Júlio Prestes (MEYER, 1999).

O termo "estagnação urbana" na passagem acima está preso à questão dos investimentos públicos, um dos itens sobre os quais o conceito de estagnação urbana, no presente trabalho, está pautado. O investimento público se evidencia por ser um elemento que acarreta interferência direta na área analisada. A ausência ou a ingerência de investimentos pode produzir a estagnação urbana em partes da cidade.

Mais uma autora usa o termo "estagnação urbana": Odette Seabra, em São Paulo: a cidade, os bairros e a periferia: 
Por outro lado, nos distritos centrais do Município, onde estagnação e deterioração urbana ${ }^{7}$ seguem juntas, são visíveis as orientações e estratégias que visam reestruturar o espaço e com isso criar possibilidades para novos usos, por meio das políticas de espaço (SEABRA, 2004:280).

É nítida a distinção que a autora faz entre estagnação de deterioração. Não explica a razão, mas demonstra uma compreensão diferente para as duas palavras, caso contrário não haveria motivo para destacar uma da outra. Prosseguindo, diz:

A obsolescência e desativação pertencem à história da cidade; seja fenômeno contínuo de substituição, seja como abandono repentino que inesperadamente muda a geografia urbana (SEABRA, 2004:105).

A obsolescência e a desativação não implicam apenas mudança da distribuição das atividades, ou da tipologia dos usos, ou ainda da deterioração física dos edifícios no espaço urbano.

Indicadora de uma impossibilidade, a obsolescência e desativação freqüentemente implicam mudança de escala e de relações espaciais (idem: 106).

O processo de reestruturação da metrópole decorrente desse fenômeno complexo de obsolescência e desativação tem como consequência a estagnação urbana, que se caracteriza, entre outros aspectos, pela desagregação dos moradores, que se veem privados das referências espaciais e temporais tradicionais e alijados de seu próprio lugar.

A temática abordada acima trata das áreas centrais da cidade. Essas áreas parecem hoje acometidas por inexoráveis processos de exclusão e segregação. Como o urbanismo é impotente em relação a essas áreas, assinala-se a importância da mobilização social e da autogestão como forma de mudar o rumo da estagnação urbana.

A esse enfoque do termo "estagnação urbana", pode-se acrescentar o conceito de "deterioração urbana" apresentado pelo

\footnotetext{
${ }^{7}$ Grifo da autora
} 
professor André Martin no texto "A permanência da deterioração urbana como processo: o caso do bairro do Brás em São Paulo" (MARTIN, 2004). Nesse artigo o conceito de deterioração urbana é construído a partir da compreensão do biólogo, professor e urbanista Patrick Geddes, que fez uso do termo, em 1909, ao analisar as condições precárias e de abandono do centro histórico medieval de muitas cidades europeias (MARTINS, 2004).

Por mais semelhantes que possam ser as duas expressões, a abrangência da palavra "estagnação" pode atingir limites e contradições mais vastos em diversas disciplinas, como na economia, na antropologia, na história, na geografia e mesmo no urbanismo. Por essa razão é a palavra-chave deste trabalho.

\section{1.e - O conceito de estagnação urbana}

Após a análise dos significados da palavra "estagnação" nas disciplinas, na imprensa, na academia e confrontando com a compreensão leiga do termo, construímos um conceito de estagnação urbana para o presente trabalho.

A elaboração do conceito partiu da apreensão empírica do fenômeno, que deve servir de guia e orientação crítica. Por outro lado, foi contemplado, também, o significado da palavra "estagnação" quanto a seu uso em outras disciplinas.

Pode-se definir a estagnação de um bairro como a interrupção do curso de sua dinâmica urbana, de sua tendência evolutiva, do caminho que estava sendo percorrido. Espaços estagnados são partes do espaço urbano que durante um período se mantêm à margem das dinâmicas sociais e econômicas que dominantemente se relacionam com a estruturação espacial da cidade. Os espaços estagnados são espaços desintegrados e ligados aos espaços integrados à economia global. A tendência do processo de estagnação é romper o movimento original do bairro, tomando uma direção contrária à que estava tendo. 
Aplicaremos esse conceito a diversos aspectos do bairro do Pari, analisando sua suposta falta de progresso, de movimento (da sua população, do seu território ou de sua organização social) e de suas atividades. A análise abordará cada um dos diversos aspectos do bairro e focalizará a história desse aspecto, ou seja, tal como ele se manifestou no tempo e como vem se manifestando. O objetivo é avaliar, por meio da história, até que ponto houve - ou não - estagnação. Assim, serão analisadas as seguintes histórias:

1. História da formação territorial do bairro

2. História social

3. História demográfica

4. História da ocupação urbana

5. História da atividade imobiliária

6. História da atividade econômica

7. História da ação do Poder Público sobre o espaço

A questão da estagnação urbana está estritamente ligada a um sentido capaz de sintetizar os problemas sociais, econômicos, demográficos, físico-territoriais, cotidianos e de usos conflitantes do espaço urbano, revelando um conceito capaz de explicar a realidade urbana em suas profundas contradições. A estagnação faz parte do processo de movimento/momento da dinâmica da cidade, onde a segregação socioespacial revela separações que tiveram origem na forma como a cidade capitalista territorializou-se no espaço da metrópole (SEABRA, 2004). A estagnação urbana é sintetizada como um processo de desvalorização imobiliária, pouca alteração dos usos existentes, aumento do número de habitações subnormais ou sem utilização, alto índice de violência urbana, perda de população moradora e diminuição da atuação dos movimentos sociais.

Uma pergunta inicial deste trabalho é se a estagnação se configura como um fenômeno intrínseco à reestruturação das grandes cidades, ou se é apenas a imagem de um processo que faz parte de sua dinâmica. O sucesso ou o fracasso de um bairro pode ser uma invenção ideológica, uma construção de ideias, uma representação. Muitas vezes, acontecimentos que parecem naturais ou espontâneos são na verdade fabricados. A ideologia dominante cria essa naturalização, o que no fundo 
é uma estratégia que tem por objetivo criar fatos políticos e sociais, que modificam, ou não, a visão da sociedade. Até que ponto as ideias são manipuláveis? Muitas vezes torna-se evidente a intenção de usá-las para a manipulação política e, principalmente, dos negócios. 


\section{A estagnação no distrito do Pari: uma investigação}

\section{2.a. A história da formação territorial do bairro}

\section{I - O bairro e o distrito}

Os distritos são unidades territoriais criadas por lei municipal. No município de São Paulo, a lei $\mathrm{n}^{\circ}$ 11.220/1992 instituiu a divisão geográfica dos 96 distritos da capital. Essa delimitação geográfica foi formada pela agregação de setores censitários do $\mathrm{IBGE}^{1}$. O distrito do Pari engloba dois bairros: o bairro do Canindé e o do Pari.

Para os fins deste trabalho não faremos diferença essencial entre o bairro e o distrito do Pari, pois os mesmos processos urbanos ocorrem tanto num como no outro, com pouquíssimas diferenças. No caso de estatísticas, o distrito é sempre a unidade territorial adotada, seja pela Prefeitura, seja pelo IBGE. Neste caso é quase inevitável que o distrito seja a unidade territorial adotada.

Bairro, no presente trabalho, é entendido como um conceito antropológico, decorrente da percepção de seus moradores, e não possui um limite físico rígido. É o lugar em que se concentram as pessoas, permitindo o estabelecimento de relações personalizadas e duradouras, que constituem a base da particular identidade produzida naquele espaço. Pertencer a uma parte da cidade significa sentir-se protegido. Significa poder ser reconhecido a qualquer momento, implicando o cumprimento de determinadas regras, que até mesmo os possíveis marginais, de alguma forma, também acatam.

O conceito de bairro aqui adotado foi magnificamente exposto por Ecléa Bosi, em Memória da cidade: lembranças paulistanas, nas seguintes palavras:

\footnotetext{
${ }^{1}$ Há 96 distritos no município de São Paulo e os dados gerais do município são desagregados por distritos. O distrito é a menor unidade física de agregação dos dados sociais e econômicos do município. É possível obter alguns dados físicos e territoriais por quadra ou até mesmo por lote.
} 
Um bairro não tem só fisionomia como uma biografia. 0 bairro tem sua infância, juventude, velhice. Esta, como a das árvores, é a quadra mais bela, uma vez que sua memória se constituiu. Nas histórias de vida podemos acompanhar as transformações do espaço urbano; a relva que cresce livre, a ponte lançada sobre o córrego, a divisão dos terrenos, a primeira venda, o primeiro bazar. As casas crescem do chão e vão mudando: canteiros, cercas, muros, escadas, cores novas, a terra vermelha e depois o verde umbroso. Arbustos e depois árvores, calçadas, esquinas... uma casa pintada de azul que irradia a luz da manhã, os terrenos baldios, as ruas sem saída que terminam em praças ermas inacabadas por dezenas de anos (BOSI, 2003: 198).

No processo de estruturação da metrópole, os bairros participam como integrantes e construtores. A compreensão do bairro na metrópole perpassa pelo plano do vivido $^{2}$ e do lugar. O lugar entendido como o espaço no qual as relações sociais são vivenciadas, o espaço apropriado por moradores e frequentadores. O movimento das transformações e estagnações de áreas localizadas na estrutura da metrópole é um conteúdo do processo de reprodução social.

Assim a dinâmica urbana indica o processo de reprodução tanto no plano espacial, tanto em sua dimensão econômica, política e estratégica, quanto no plano da vida cotidiana, recolocando a produção do espaço como produção da vida na metrópole (CARLOS E OLIVEIRA, 2004: 13).

Um bairro é compreendido como uma parte, um fragmento da cidade cujos atributos se relacionam e se identificam entre si, não é apenas uma divisão geográfica, uma delimitação espacial. Um bairro é entendido dentro

\footnotetext{
2 Para Henri Lefèbvre o "plano do vivido" significa "o lugar". O lugar como o espaço do vivido e como ponto de realização do mundo. (LEFĖBVRE, 2000). Ana Fani A. Carlos definiu maravilhosamente o "plano do vivido" ao analisar a obra de Dostoievski: "os sofrimentos, a humilhação presentes, mas também a alegria, a emergência do desejo, o acaso que produz as metamorfoses da vida cotidiana, dando importância ao 'acidental' e a 'subjetividade' que muda o sentido repetitivo; nessa dimensão, o repetitivo contém coisas novas, capazes de engendrar diferenças, pois ela contém o devir" (CARLOS, 2001:306).
} 
do conceito antropológico, no qual a apropriação dos moradores e dos "usadores" 3 (Lefèbvre) do lugar é que determina suas características sociais e portanto seu limite. Assim, um bairro não é visto apenas no seu limite físico, mas como uma unidade estruturada, organizada, de grupos, dispondo de certos momentos de hierarquia homogênea de valores à qual o indivíduo pertence necessariamente. É um determinado espaço onde ocorrem as relações sociais dos moradores e frequentadores, e é nessa reprodução das relações sociais do cotidiano que o bairro se realiza e se estabelece.

Os bairros, que juntamente com os núcleos de povoamentos fizeram parte do desenvolvimento da estrutura da metrópole, proporcionam aos seus moradores condição de um tempo comum e um cotidiano sem necessariamente produzir exclusões absolutas do ponto de vista da lógica capitalista (SEABRA, 2004:273).

Ao olhar a história de um bairro - enquanto recorte espacial - é possível reconstruir o espaço urbano, e inseri-lo na cidade, restabelecendo suas relações com as demais partes do conjunto. Reconstruir o passado dos bairros de São Paulo significa percorrer a trajetória da cidade em suas etapas significativas, destacando o peso e o papel que tais fragmentos desempenharam no processo histórico. Deter-se sobre a história da metrópole, percorrendo-a do passado para o presente, do particular para o universal, retornando do presente à gênese, leva à compreensão da realidade, permite perceber e apreender as diferenças, a complexidade, os conflitos e as contradições. Reconstruir a história dos bairros é captar a diversidade, a aparência e a essência, desde as estruturas da produção material da vida até os fatores culturais e ideológicos que as reproduzem.

Cada bairro tem seu movimento inserido na estrutura da metrópole, e sua dinâmica própria, fechada em si mesma. Por exemplo, nota-se que a realidade do Pari é traduzida em práticas cotidianas de indivíduos que se ignoram mutuamente, cada um deles fechado no horizonte limitado de sua família e de sua profissão. Essa é uma situação que pode ser vivenciada por outros bairros semelhantes, como Bom Retiro, Santa Cecília, Sé, República,

3 No conceito de Henri Lefèbvre, o usador é o que se apropria efetivamente do espaço urbano. Lefèbvre via uma ambiguidade na palavra usuário. 
Cambuci. Talvez, desses citados, o mais esquecido pelo poder público ou pelos formadores de opinião seja uma parte do distrito do Bom Retiro, ao redor da Estação Armênia, precisamente entre a avenida Cruzeira do Sul e a linha elevada do metrô Norte-Sul (o bairro da Ponte Pequena). Ali, a forma como o sistema viário cortou o bairro e instalou a linha de metrô isolou a área de qualquer outro relacionamento com os espaços vizinhos.

Em São Paulo, no fim do século $X I X$ e começo do século $X X$, os trabalhadores ocuparam principalmente as áreas próximas às indústrias, nas margens dos rios Tamanduateí e Tietê e ao longo das ferrovias. Essa ocupação, no despontar da metropolização, que também coincidiu com o início do século $X X$, proporcionou uma segregação social que pode ser expressa na condição de moradia da maioria da população paulistana, que vivia em casas alugadas. Nessa época, os dados (tabela 1) mostram que 80\% das habitações em São Paulo eram alugadas (CALDEIRA, 2000).

TABELA 1 - Domicílios segundo a condição de ocupação (\%), Município de São Paulo.

Tabela 1 - Domicílios Segundo a Condição de Ocupação (\%), Município de São Paulo.

$\begin{array}{lcccccc}\text { Condição/ocupação } & 1920 & 1940 & 1950 & 1970 & 1991 & 2000 \\ \text { Alugados } & 79 \% & 67 \% & 58 \% & 38 \% & 28,75 \% & 21,6 \% \\ \text { Próprios } & 19 \% & 25 \% & 37 \% & 54 \% & 63,57 \% & 69,4 \%(1) \\ \text { Outros (2) } & 2 \% & 7 \% & 5 \% & 8 \% & 7,68 \% & 9,0 \%\end{array}$

(1)Imóveis próprios e em aquísição.

(2)Domicilios cedidos e outras formas de acesso.

Fontes: para 1920, Boletim da Diretoria de Indústria e comércio, apud Bonduki, (1998); para 1940, 1950 e 1970, IBGE, apud Bonduki (1998); para 1991 e 2000, censo IBGE (SEHAB, 2004:7).

Assim, bairros inteiros existiam sem, no entanto, ser reconhecidos como parte da cidade oficial e a alta densidade do território popular causava repugnância e preocupação às elites, que se defendiam construindo bairros exclusivos e propondo favores fiscais e liberalidades construtivas para os empreendedores que desejassem construir casa populares em zonas precisamente delimitadas para tal, fora do perímetro central (ROLNIK, 1997: 145). 
O cotidiano de um bairro é um dado revelador de seu desempenho na cidade, e a forma mais eficaz de medir o resultado de sua prática é através do noticiário. Para Jacobs (1973) um bairro bem-sucedido é aquele que enfrenta e resolve de forma razoavelmente eficaz seus problemas, de modo que ele não se destrua. Um bairro malsucedido é o que se encontra sobrecarregado de deficiências e problemas e cada vez mais inerte diante deles. É no cotidiano que se percebe a insuficiência de um bairro. A lentidão com que o bairro encaminha ou resolve seus problemas tem um custo imediato imensamente maior ao dos resultados que se pretende atingir, sempre demorados e muitas vezes não obtidos.

O Pari está situado muito próximo ao centro histórico da metrópole, sendo assim indissociável do mesmo: o centro e o bairro apresentam um manancial fértil de contradições que permite discutir toda essa sociedade. Cada um adquire funções quase específicas e ambos revelam características gerais - que se materializam num todo representativo da diversidade da lógica urbana. O processo de estruturação da metrópole engloba os bairros e a intersecção entre eles, ou seja, os fenômenos dentro do urbano que estão relacionados e articulados com os bairros, mesmo que ocorram fora deles. Portanto, é importante situar o distrito do Pari na metrópole, mostrar suas características geográficas e a história de sua ocupação territorial.

\section{II - A história das transformações do bairro}

O distrito do Pari é composto pelos bairros Canindé e Pari. O distrito do Pari está situado na confluência dos rios Tietê e Tamanduateí, na margem esquerda do Tietê (mapa 2, p.38), em área contígua ao distrito da Sé, a nordeste do centro histórico do município. O Pari já pertenceu à Administração Regional da Sé e hoje está inserido na subprefeitura da Moóca, desde a criação das subprefeituras (Lei $n^{\circ} 13.399 / 2002$ ). Por ter relação estreita e histórica com o Centro e a Sé, os moradores do Pari 
repudiam essa mudança e não assimilam que o distrito pertence hoje à Moóca. Antes, o desenho da área central, com o distrito do Brás e do Pari, era praticamente um círculo, com os pontos periféricos equidistantes do Centro. Hoje, com a exclusão do Pari e do Brás, a figura tornou-se deformada, banguela (mapa $\mathbf{2}$ ).

\section{Mapa 2 - Área central do Município de São Paulo}

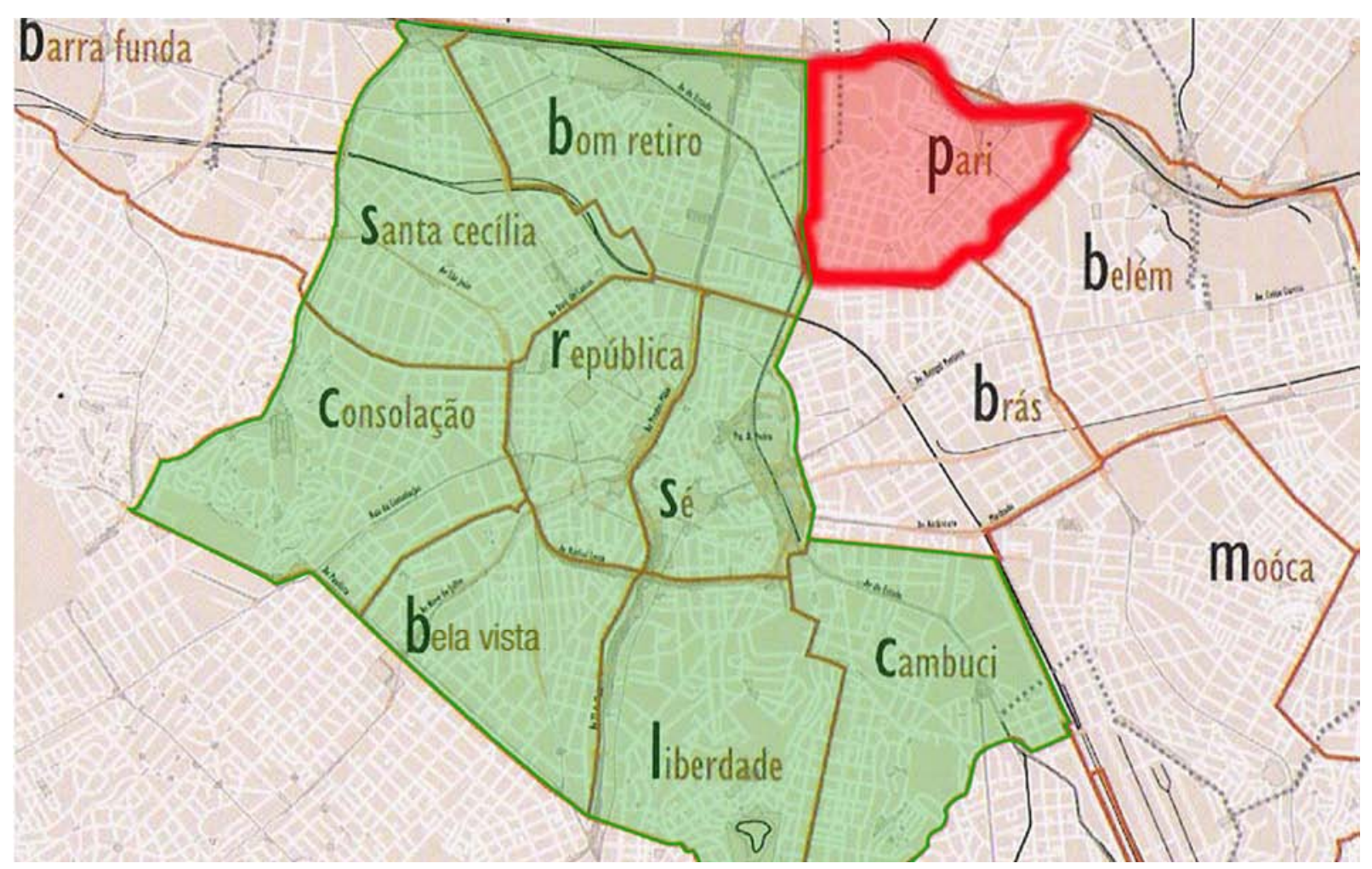

Fonte: CDHU/ Secretaria de Economia e Planejamento/ Governo do Estado de São Paulo/ 2006

O distrito possui sua maior área em planície de inundação, com terraços fluviais típicos entre 724 e 730 metros de altitude (mapa 3). Destaca-se, em particular, o Alto do Pari, onde ocorre um acidente geomorfológico, encontrado na zona de transição entre os terraços do Brás e da Moóca, pontos raros na configuração do município de São Paulo que constituem "verdadeiros 'assoalhos' mais salientes da antiga capa sedimentária aluvial dos terraços típicos em nível 730 a 735" (AB'SÁBER, 1958). 
A primeira citação sobre a história da ocupação do Pari é de 1593, quando já existia o caminho do Pari, que ligava o centro da cidade ao morro da Moóca. Pelo recenseamento de 1765, era possível notar a presença do Pari em São Paulo, com 74 casas identificadas - a primeira faísca para o surgimento do bairro. Na história contada por seus moradores, o bairro começou a germinar por volta de 1576; contudo, nos mapas de São Paulo dessa época, não é possível visualizar nenhuma ocupação na área.

\section{Mapa 3 - Relevo do distrito do Pari - MSP}

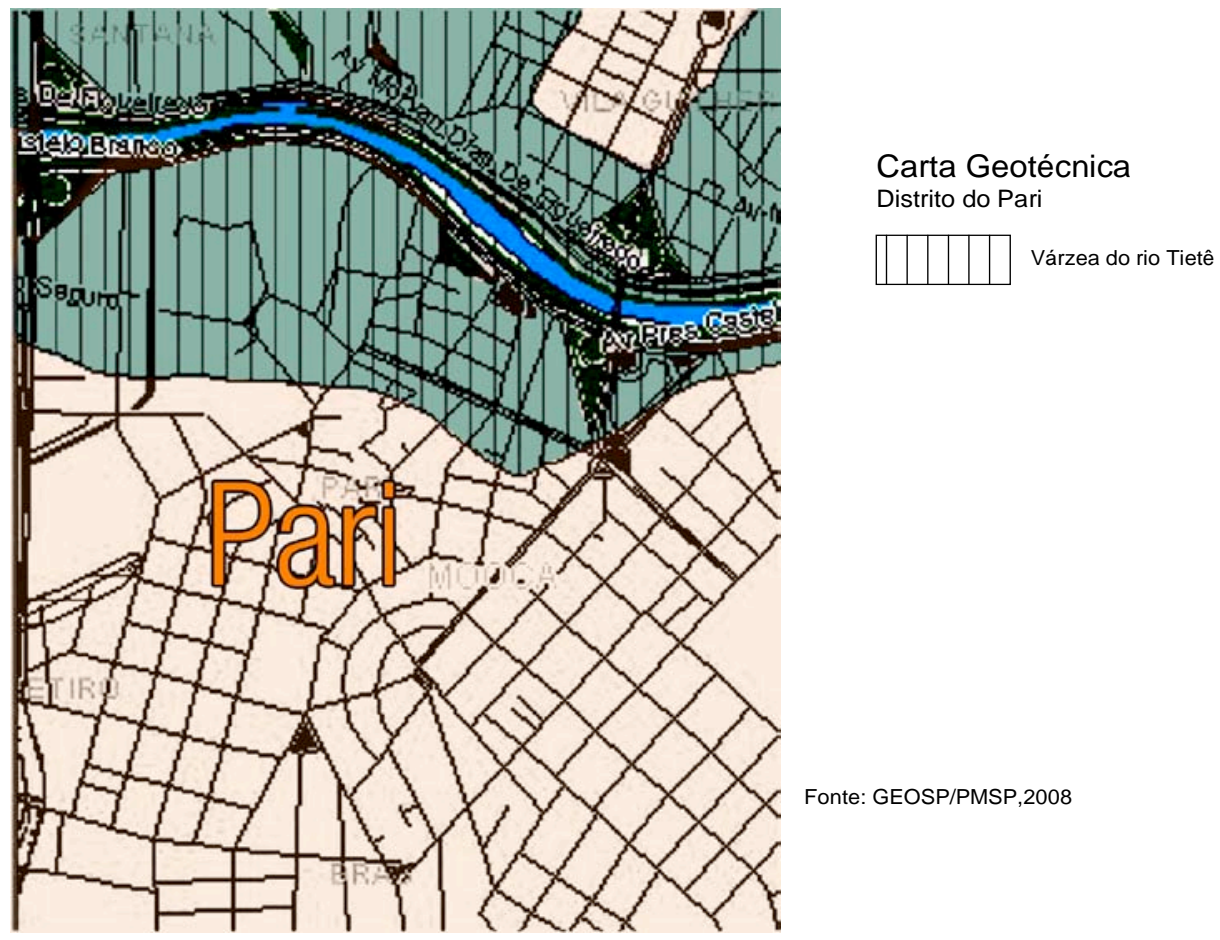

Para possibilitar a ocupação da área onde se situa o distrito do Pari, era necessária a retificação do rio Tietê, pois suas águas envolviam grandes trechos do bairro do Canindé. Em São Paulo, desde 1842, as propostas de retificação dos seus principais rios - Pinheiros, Tamanduateí e Tietê - já se apresentavam, para solucionar os problemas das enchentes cada vez mais frequentes na cidade. Em 1892, por decreto do Governo Estadual, foi nomeada a Comissão de Saneamento do Estado para estudar as várzeas dos 
rios Tamanduateí e Tietê; e, em 1928, Saturnino de Brito apresentou o, em 1928, Saturnino de Brito apresentou o projeto de retificação do rio Tietê entre Osasco e a barragem da Penha, com o propósito explícito de diminuir as inundações do rio Tietê.

O combate às inundações nos arredores da capital é o grande objetivo da Comissão na década de 20. As inundações aparecem como fenômeno histórico, num certo sentido redefinindo o significado das cheias naturais episódicas do rio e das várzeas, para constituir-se em flagelo. As cheias são um fenômeno do rio, as inundações um fenômeno social (SEABRA, 1987: 130).

Em 1849, com a retificação do rio Tamanduateí foi eliminada uma parte de sua várzea e construída a Ponte Pequena sobre o rio Tamanduateí, com a qual o Pari se beneficiou. Essa ponte ligava a rua Pedro Vicente ao Bom Retiro e atravessava os trilhos da Ferrovia da Cantareira em nível.

A retificação do rio Tietê, contudo, só veio a acontecer nas décadas de 1950 e 1960. Foi uma tentativa de resolver a questão das enchentes, mas teve também a motivação de gerar lucros aos que haviam se apropriado das áreas novas criadas na antiga várzea. A canalização do rio Tietê aumentou a capacidade do escoamento das águas, mas os trabalhos de escavação caminharam a passos lentos, prosseguindo durante os anos 60 e também nos anos 70, quando ainda havia por fazer obras de acessos, vertedouros, desentupimento de desvios e do leito antigo. À medida que as obras avançavam, novos problemas apareciam. Pode-se dizer que até hoje eles não foram saneados, pois ainda há enchentes nas antigas várzeas do rio Tietê, sobretudo no bairro do Canindé e as obras de desassoreamento continuam sendo executadas. Essas obras não tinham seu fundamento numa visão ambiental e social da cidade. As finalidades eram: diminuir as enchentes em alguns pontos, tirando vantagem do monopólio da produção e distribuição de energia advindas das barragens executadas ao longo dos rios Tietê e Pinheiros; e, principalmente, favorecer o grande mercado de terras com as áreas criadas a partir dos aterros das várzeas. Assim foi-se dando a 
ocupação das áreas inundáveis do rio Tietê - até hoje, na estação das chuvas, o antigo leito do rio floresce e inunda essas áreas ocupadas.

A ocupação sistemática do distrito do Pari iniciou-se em 1856, de acordo com a notícia extraída de um recorte do jornal Notícias Populares de 1976, onde um morador relata que, nesse ano, uma propriedade (de Dona Angélica Maria, Caetano José Rodrigues, Francisco Antônio Borba e José Inácio de Araújo) foi loteada, passando a se chamar Canindé (Arquivo Municipal, SMC/PMSP). No entanto, nos mapas de 1840 e 1895 (mapa 4) não se pode identificar qualquer ocupação ordenada no bairro do Canindé.

Foto 1 - Ponte Grande (sobre o rio Tietê) em cartão-postal

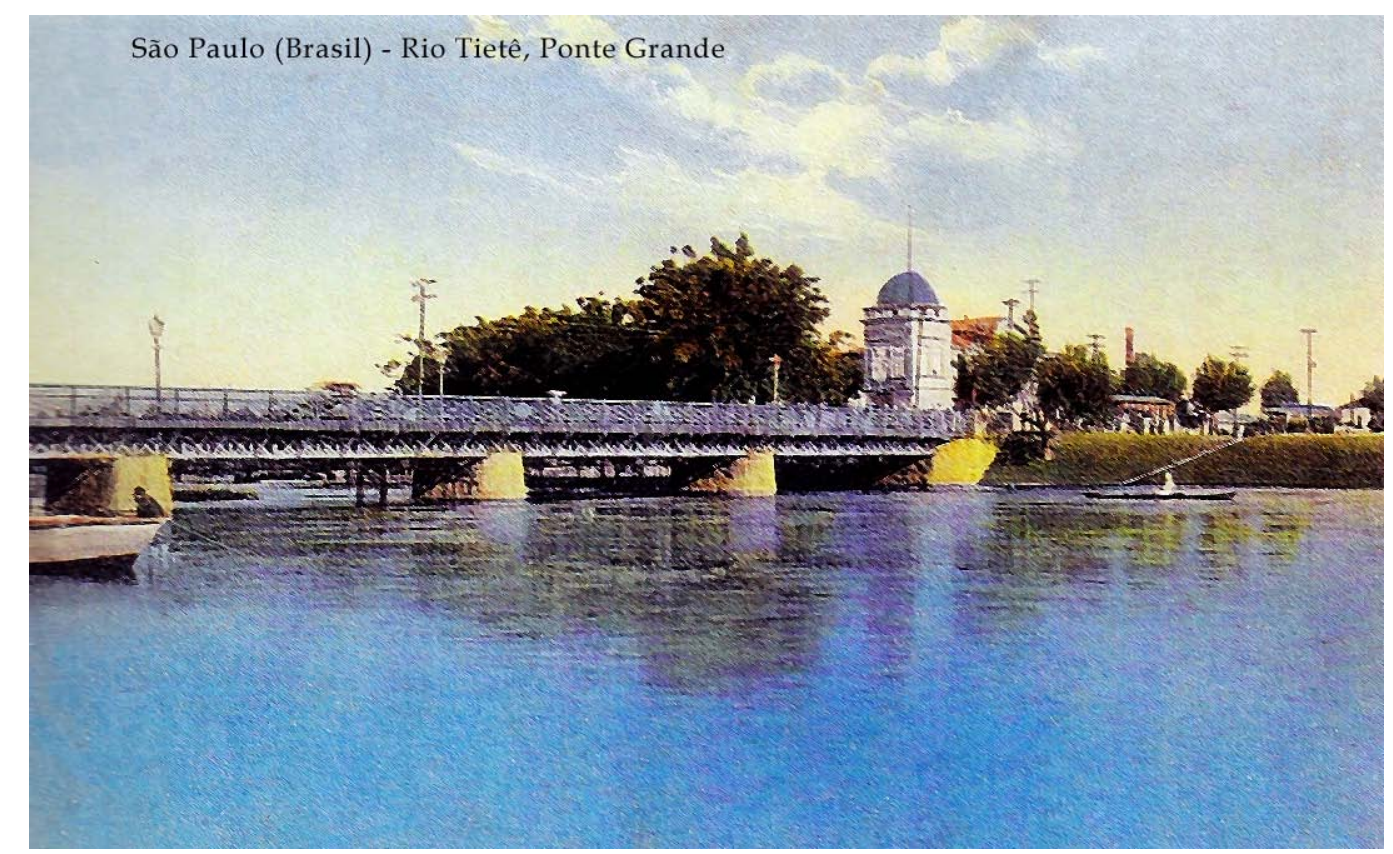

Fonte: AMADIO, Decio, 2004: 185. 


\section{Mapa 4 - O Pari em 1840 e 1895}
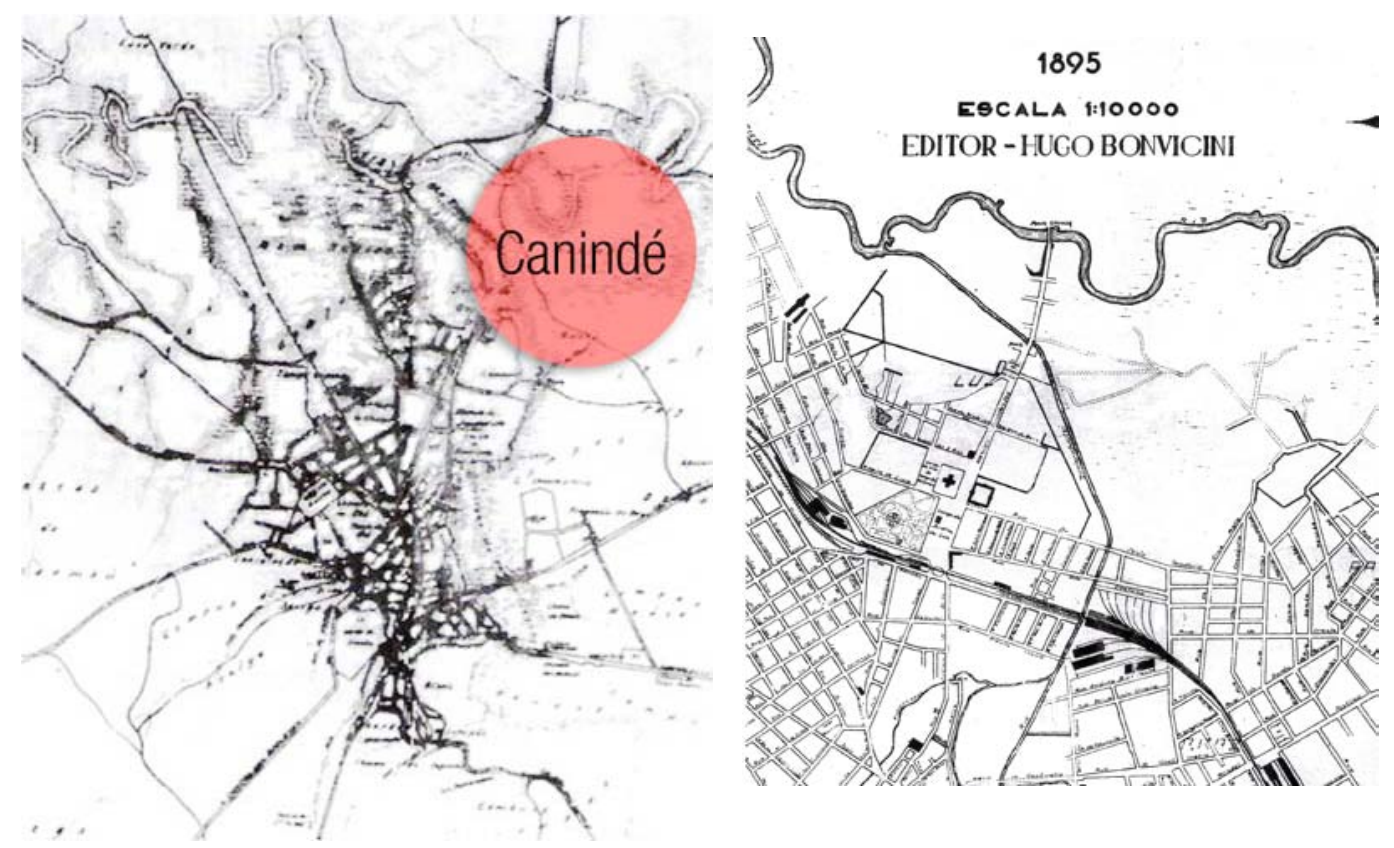

Fonte: Arquivo Municipal - Secretaria Municipal de Cultura - PMSP

Existem, apenas, vias que cortam a área no sentido leste-oeste, ligando o rio Tamanduateí ao Brás, irrompendo como uma área de portos de areia à margem do Tietê, entre a Ponte Pequena, que cruzava o rio Tamanduateí e era caminho para a Ponte Grande, que, por sua vez, cruzava o Tietê. A primeira Ponte Grande (foto 1) foi construída em 1675. Vinte e cinco anos depois, em 1700, foi substituída por outra, que, aparentemente, resistiu até o final do século, quando então foi construída outra ponte, dessa vez com base de alvenaria (tijolo e cimento, em vez de apenas madeira) (Ogawa, 2009).

Ernani da Silva Bruno confirma que até 1870 o bairro era despovoado (BRUNO, 1954). A primeira indicação do Pari em plantas do município de São 
Paulo é de 1890, de Jules Martin (mapa 5), que mostra uma ocupação ao longo dos trilhos da Estrada de Ferro Santos-Jundiaí. Mesmo com a implantação da ferrovia da Cantareira, que passava onde hoje é a Avenida Cruzeiro do Sul, a área lindeira à ferrovia era desocupada até 1915.

\section{Mapa 5 - 1890 - Planta da capital do Estado de São Paulo, Jules}

\section{Martin}

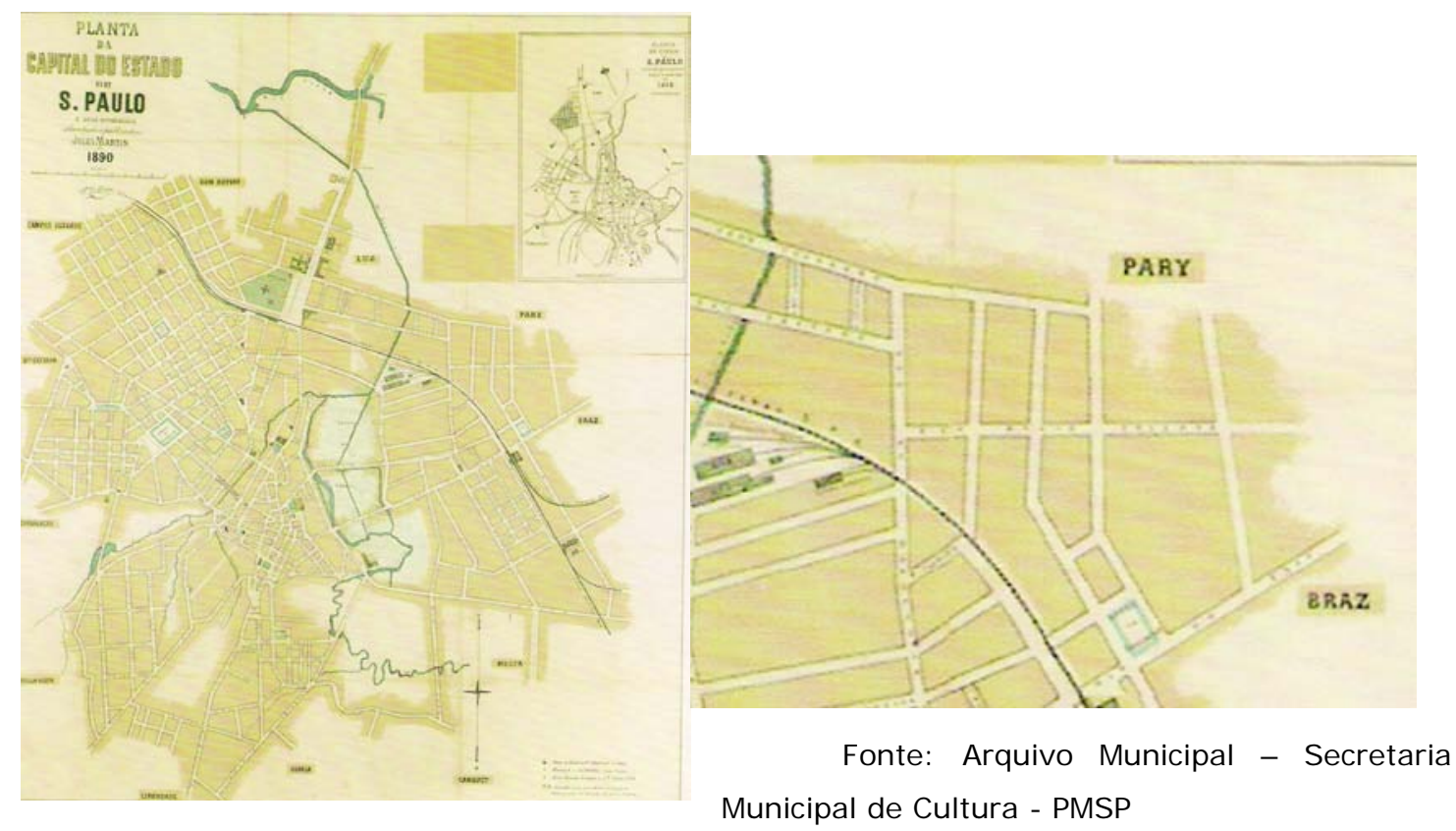

Na planta de 1890 (mapa 5) consta a denominação Pary, mas, como se trata de uma planta de rios, não há especificação dos bairros. Na planta de 1895, já aparece o bairro, com suas várias ruas. Junto ao bairro do Pari, o bairro do Canindé, conhecido anteriormente por Guaré, loteado a partir de uma chácara de Couto de Magalhães, em 1856, adotando o nome de uma das principais cidades do estado do Piauí, Canindé (AMADIO, 2004:358).

O Pari teve um desenvolvimento bastante rápido após 1885, assim como toda a cidade. A proximidade com o centro principal e a implantação da estrada de ferro, com a estação e a alfândega seca do Pari, possibilitaram sua ocupação e determinaram sua vocação. Passava, ainda, pelo Pari o caminho de tropas que levava ao morro da Moóca e prosseguia para a 
Freguesia da Penha, uma via de penetração que intensificou sua ocupação lindeira. Como testemunha dessa época e desse caminho, sobrevive o chafariz onde os tropeiros paravam para matar a sede - fica na Praça Padre Bento, mais conhecida como Largo Santo Antônio, onde se encontra a igreja de mesmo nome, fundada em 1911, ponto central do bairro (mapa 6).

\section{Mapa 6 - 1913 - Distrito do Pari}

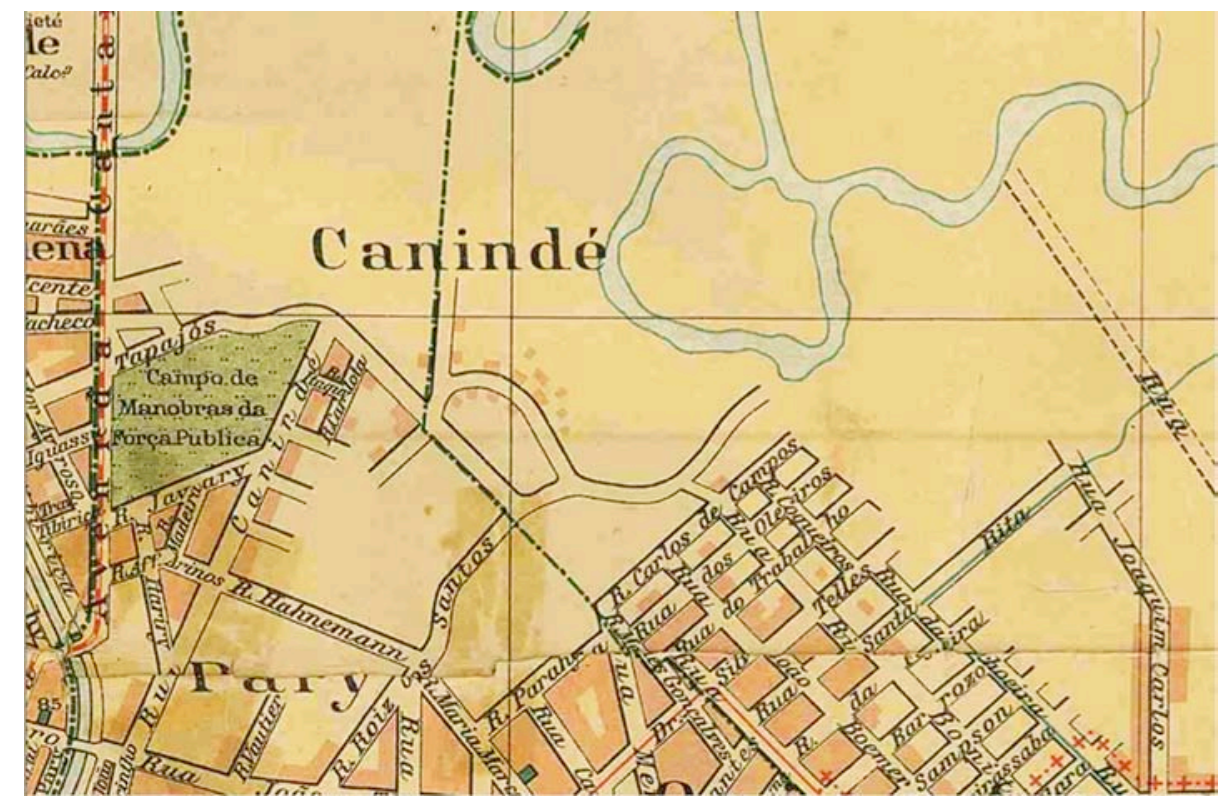

Fonte: Divisão Cadastral da 2a secção da Directoria de Obras e Viação da PMSP.

As primeiras ruas abertas "oficialmente", em 1924, se encontram em área que era propriedade do sr. Horácio Vergueiro Rudge. No parcelamento da área foram estabelecidas as regras de ocupação dos lotes. Entre elas: deveriam ter frente para as ruas novas, constantes na planta de "retalhamento"; não deveria ser construído mais de um prédio de habitação por lote, com dois pavimentos no máximo, pé-direito máximo de 3,5 m cada e caixa de ar de 0,5 metro, no máximo, e outros detalhes de construção (acto $n^{\circ} 2.284$, de 18 de janeiro de 1924)(mapa 7). 


\section{Mapa 7 - 1924 - Distrito do Pari, Município de São Paulo}

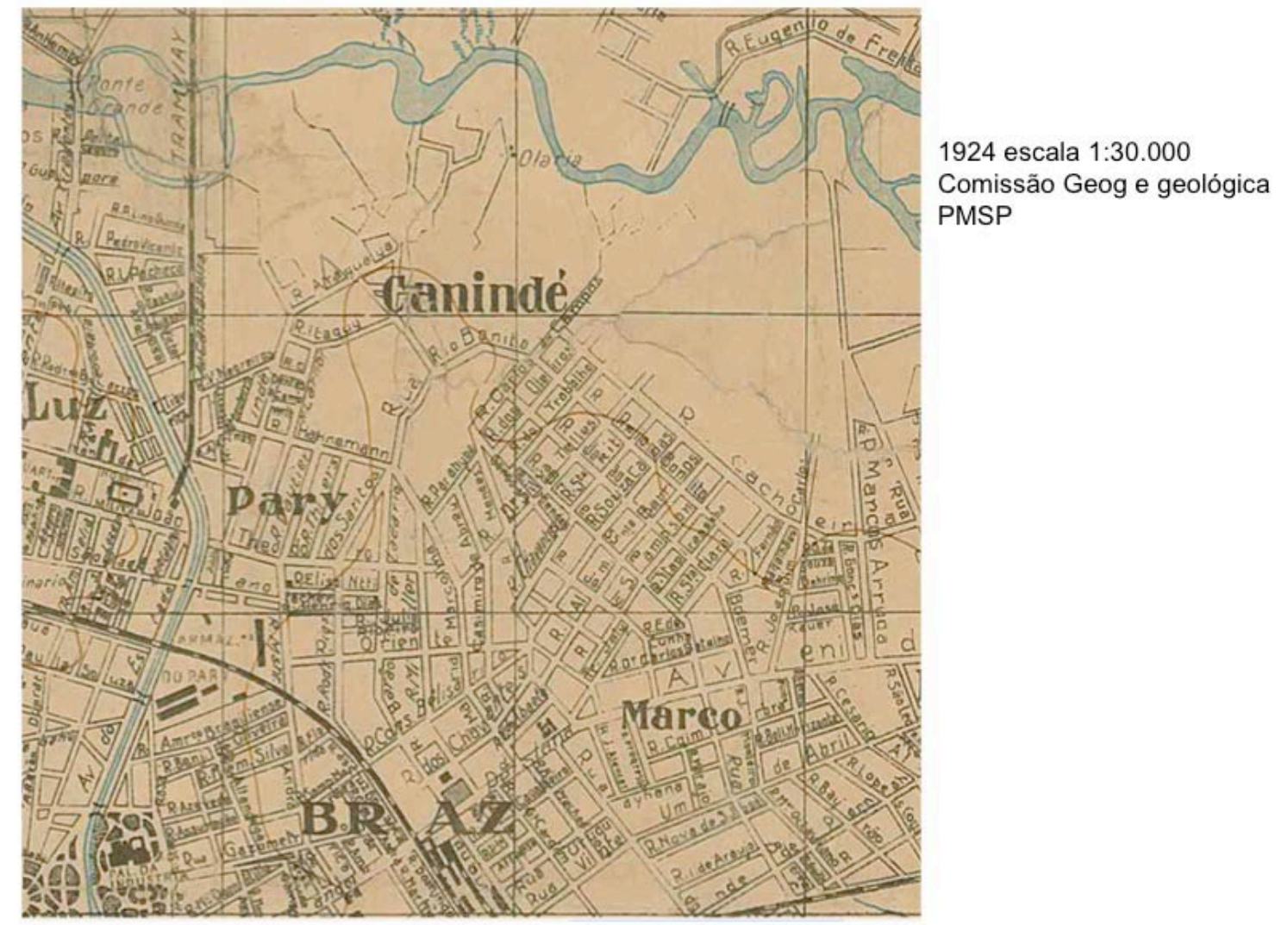

Fonte: - Comissão Geográfica e geológica - PMSP / escala original 1:30.000

A área do distrito do Pari, composto pelos bairros Canindé e Pari, prossegue seu loteamento entre 1924 e 1930. Pode-se comparar o mapa de 1924 ao de 1930 (mapa 8) com as fotos de 1940 (foto 2), e 1952 (foto 3), onde se identifica nitidamente o processo de ocupação da área. A topografia plana, de fácil implantação, aliada à proximidade do Centro possibilitou uma ocupação rápida e sem problemas com técnicas construtivas. 


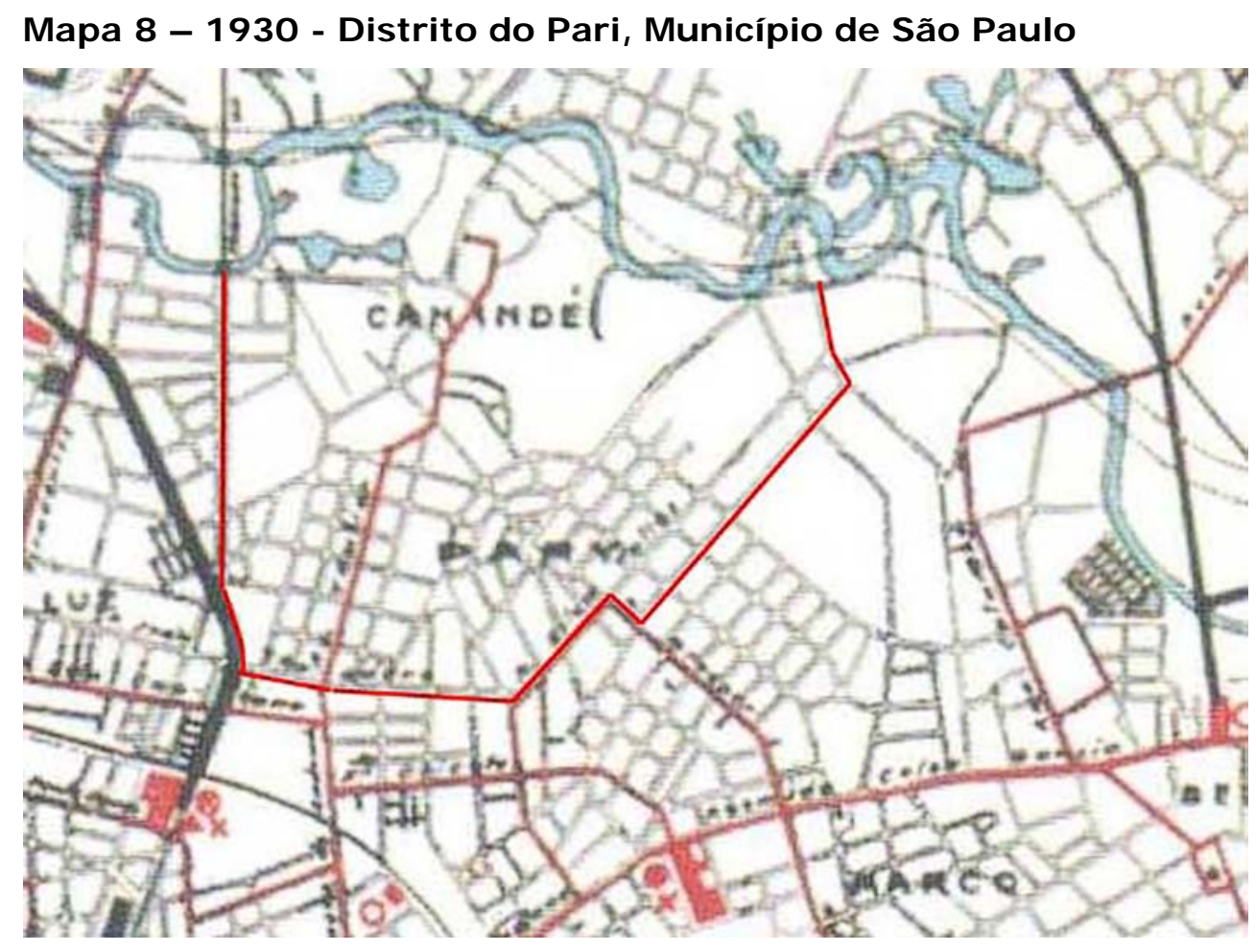

Fonte: Arquivo Municipal - Secretaria Municipal de Cultura - PMSP / escala original $1: 30.000$

Para estudar o Pari é necessário reconhecer a história do vizinho bairro do Brás, dada sua importância industrial, de centro comercial e aglutinador de uma grande população. Em 1878 os italianos Ludovico Dal Porto e Francisco Casini fundaram a primeira fábrica, em São Paulo, de indústria alimentícia, instalada nos arredores do Pari, já no distrito do Brás, na Rua Monsenhor de Andrade, continuação da Avenida Vautier, em uma modesta casa, com protestos dos moradores porque não interessava a eles serem vizinhos de uma fábrica que, com certeza, traria mais movimento às suas tranqüilas ruas. 
Foto 2 - 1940 - Distrito do Pari, Município de São Paulo

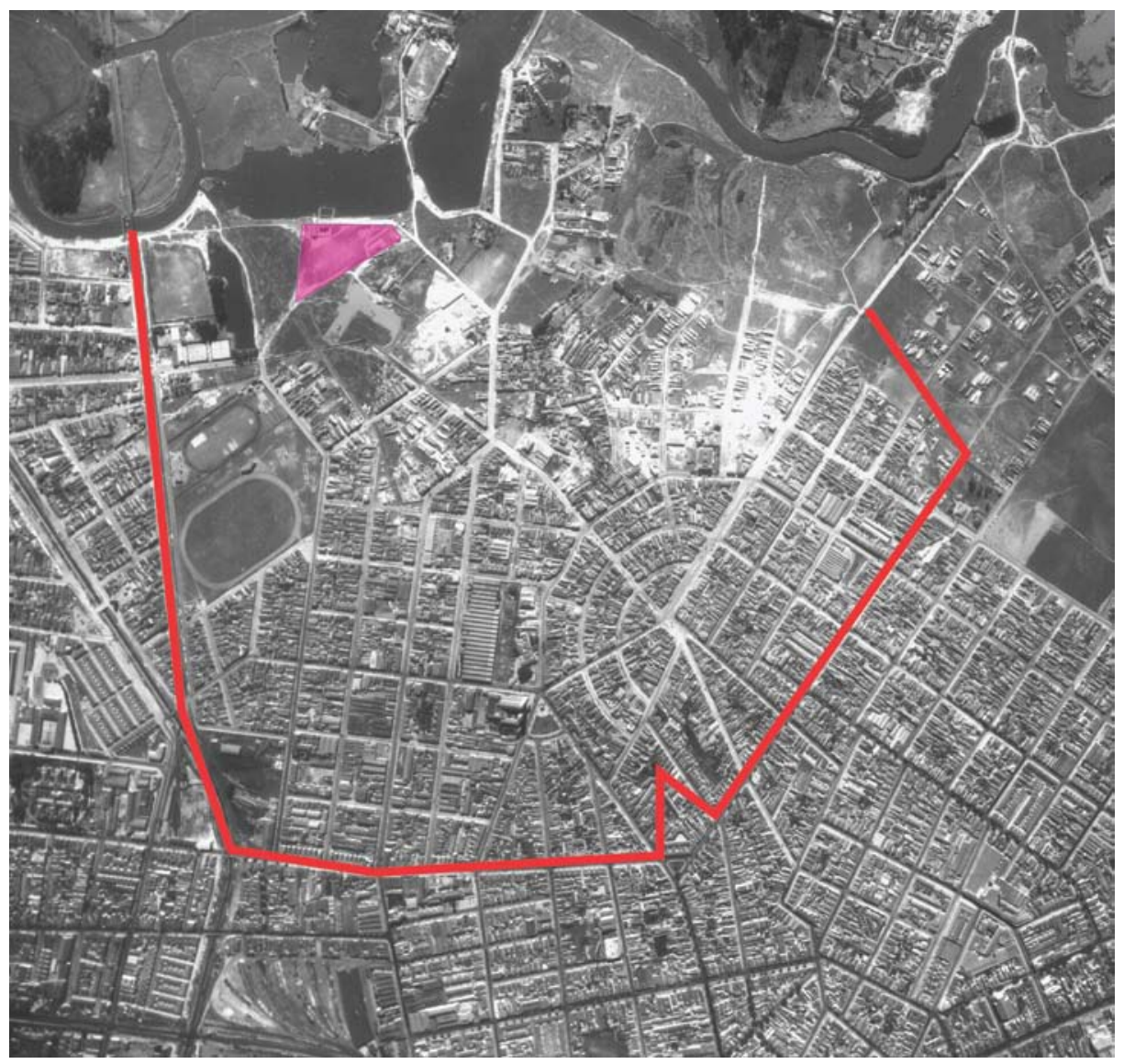

Fonte: Voo VASP, SBD/FFLCH/USP

(TORRES, 1985:113 e 114). Na época os limites dos distritos não eram os mesmos de hoje e dentro do conceito de bairro o local era indicado como Pari. Portanto, o Pari nasceu imbricado ao bairro vizinho, de modo que dependia da percepção de cada um considerar o lugar como Pari ou Brás.

Com a abertura da ferrovia que ligava São Paulo ao Rio de Janeiro, a antiga Estrada D. Pedro II, e a E. F. Santos-Jundiaí, a região começou a tornar-se importante. Além disso, a instalação da estação do Pari no trajeto da Santos-Jundiaí propiciou o surgimento de alguns arruamentos ao seu redor. 


\section{Foto 3 - 1952 - Distrito do Pari, Município de São Paulo}

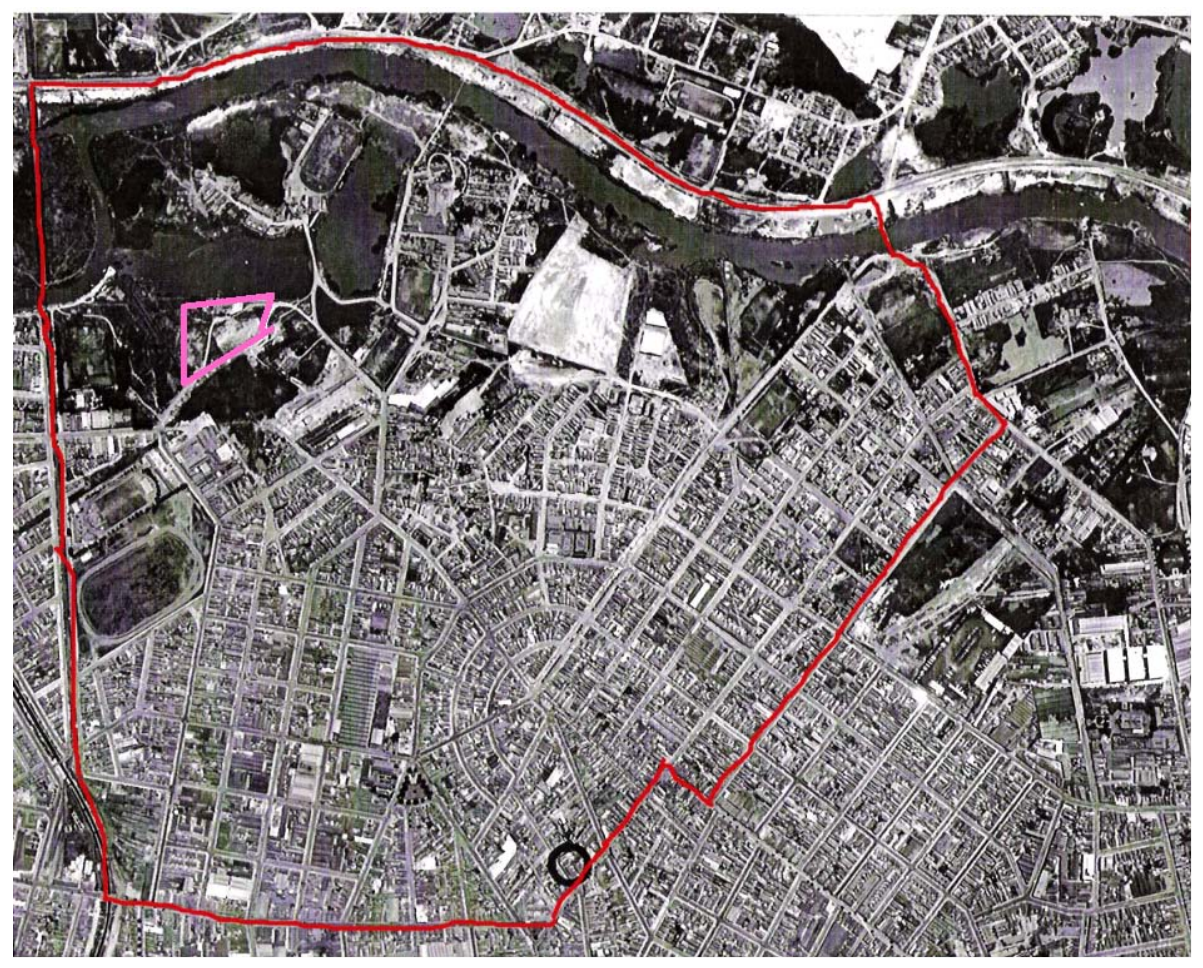

Fonte: Voo VASP, SBD/FFLCH/USP

Historicamente, as primeiras ocupações da área ainda podem ser reconstituídas em pesquisa feita nos jornais e documentos do Arquivo Histórico da Secretaria de Cultura do Município/PMSP, que mostra os primeiros proprietários do distrito do Pari:

- No século XIX, as terras do Pari aparecem como sendo de propriedade de Horácio Tower Fogg e Francisco Antônio O’Paulo (DPH, Arquivo Histórico do Município de São Paulo, SC/PMSP).

- $\quad$ Em 1896 muitas terras do bairro pertenciam a Victor Nothmann e Max Erhart (A Gazeta da Zona Norte, 1994). A fonte não menciona a localização dessas terras.

- A área da Rua Olaria até a Rua Victor Hugo de hoje era uma pasto que pertencia à família Vautier. Desocupada até 1913.

- A área da Rua Rio Bonito até a Avenida Carlos Campos e Rua Paraíba era uma chácara de propriedade de um único dono, não identificado. 
- $\quad$ Entre as ruas Capitão Mor de Passos e Guarantã ficava o Varjão dos Dias.

- Numa parte do Alto do Pari (mapa 9), nos primeiros anos do século XX, o imigrante italiano Camilo Cristófaro construiu uma vila com todas as marcas da sua aldeia natal. Hoje já se encontram algumas residências mais novas, mas as características do traçado das ruas e a morfologia das quadras continuam intactas, com suas peculiariedades.

\section{Mapa 9 - Alto do Pari e Foto 4 - R. Guimademar Leingruber}
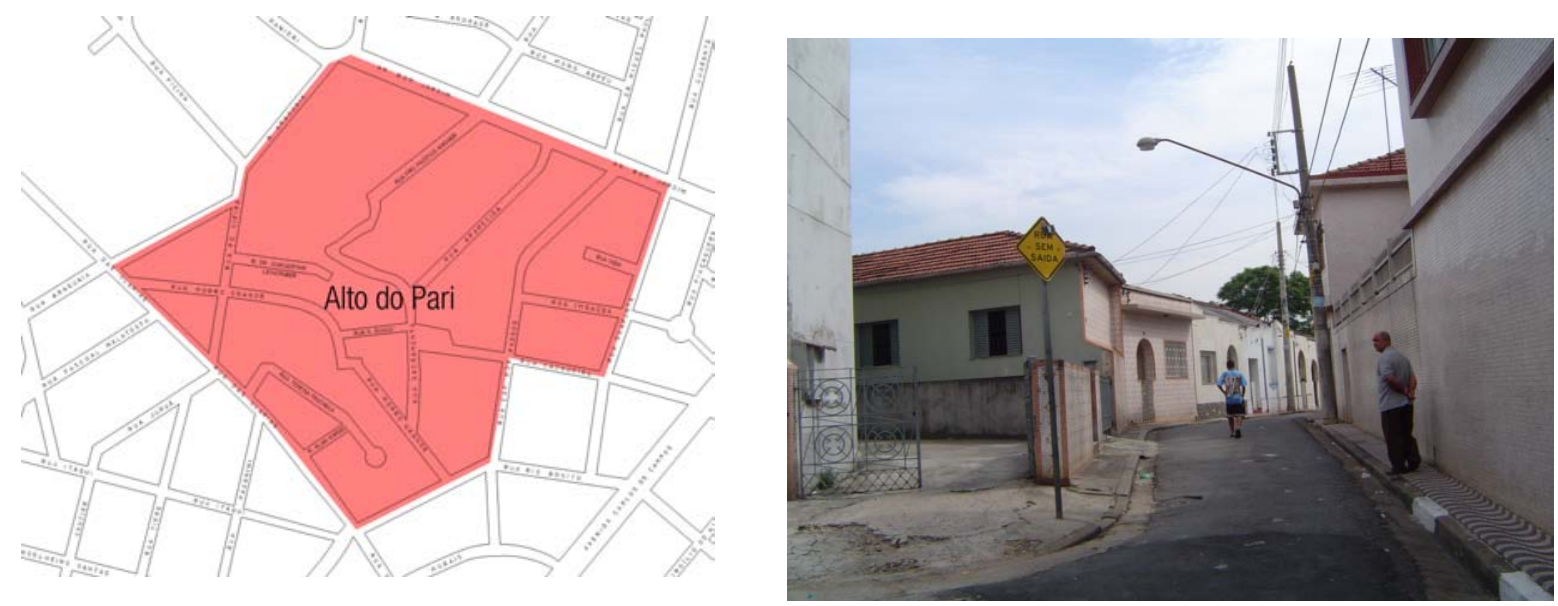

O Alto do Pari (foto 4), como é conhecido o morro do Pari, ainda conserva sinais da influência marcante dos imigrantes italianos e portugueses, em sua forma de ocupação e conformação do loteamento. Nos quintais e vilas das ruas Sacramento, São Biaggio e Morro Grande, as casas parecem se abraçar, lembrando muito as ruelas estreitas de Nápoles ou Lisboa. É por elas que ainda passam as carroças do carvoeiro e do vendedor de miúdos de boi, com sua corneta de metal apregoando seus produtos e quebrando um pouco a paz local (Notícias Populares, 1976). O mapa das terras do distrito do Pari é reconstituído no (mapa 10) de forma pouco precisa, identificando os antigos proprietários citados anteriormente. 


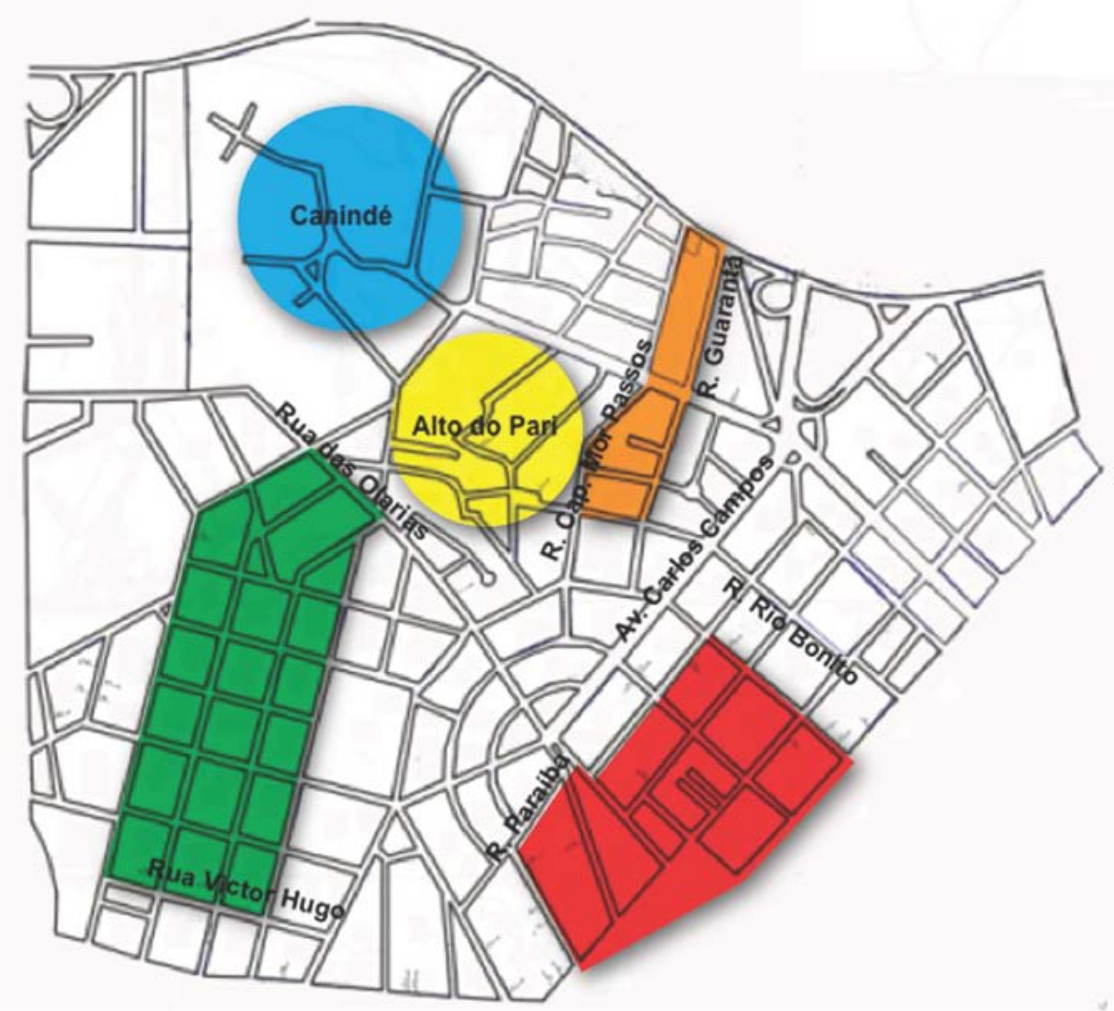

A urbanização efetiva do bairro ocorreu no início do século XX. Foi nesse período que o imigrante italiano Oliviero Fuzzari construiu cerca de 100 casas (entre elas 16 sobrados), umas na Rua Juruá (mapa 11), outras na Rua Mario Ibarra de Almeida (Belenzinho), que surgiu a partir da Rua Paulo Andrighetti (Diário Popular, 1976).

Em 1934, pela lei no 8.637 de 30 de agosto, o Pari foi elevado à categoria de subdistrito da Capital. Era o 25으 subdistrito, que nessa época ainda englobava a Vila Guilherme. O desmembramento da Vila Guilherme só foi ocorrer em 1964, deixando então o Pari de transpor o rio e abrangendo apenas a margem esquerda do rio Tietê.

Os loteamentos executados no Pari levaram a uma ocupação em pequenos lotes, com implantação de casas geminadas, sem recuo frontal e lateral, sem quintal, numa repetição contínua. Verificou-se também a 
produção de casas de cômodos, conhecidos comumente como cortiços, além da adaptação posterior de outros imóveis para esse fim.

\section{Foto 5 - Rua Sacramento - Alto do Pari}

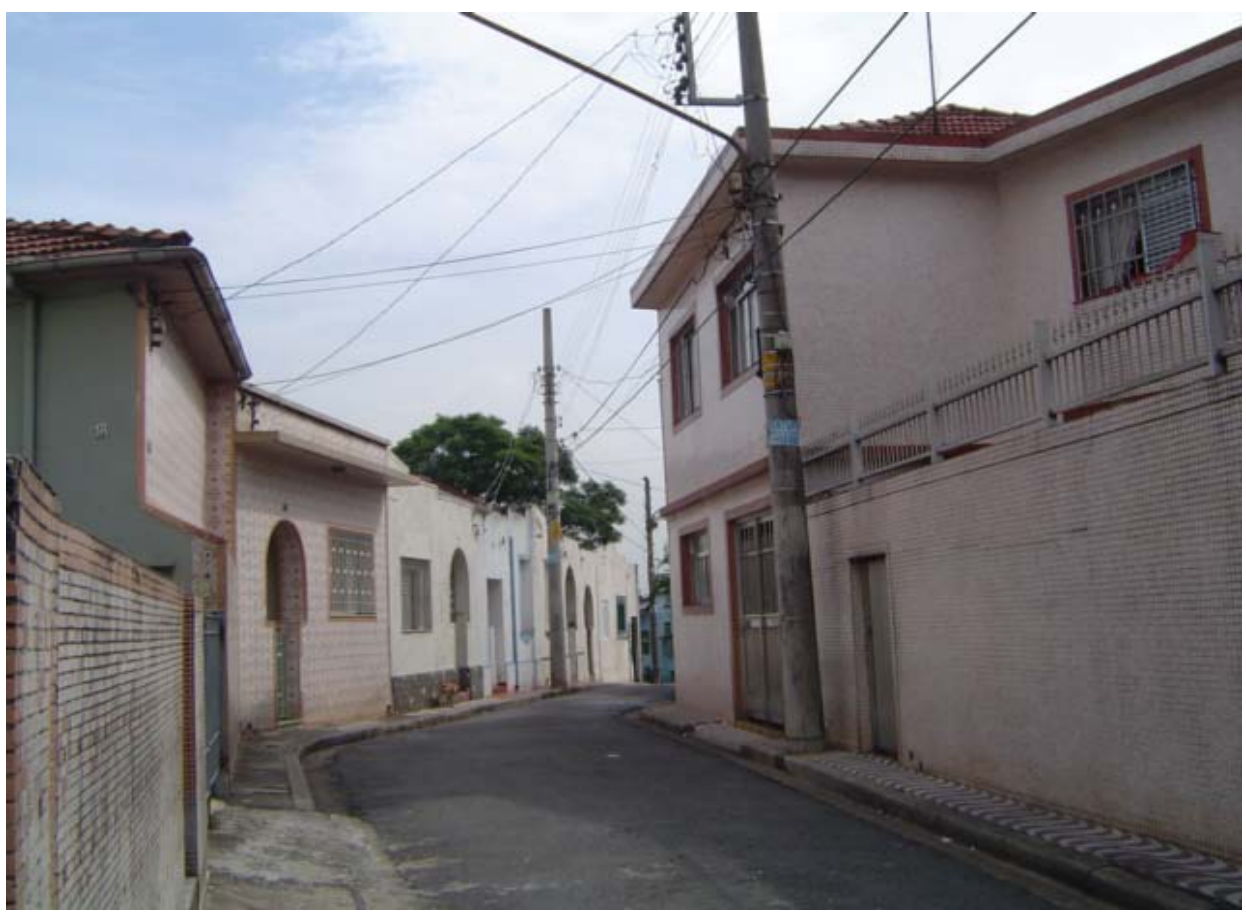

O Pari foi ocupado na sua maior parte como um tabuleiro em xadrez, do qual fazia parte grande parte do antigo leito do rio, estendido por quadras amplas. O traçado dos loteamentos, contudo, não é todo homogêneo. Embora nos mapas se visualize uma grande extensão de traçado retangular, pode-se verificar que há pelo menos dois loteamentos que diferem do traçado tradicional: o Alto do Pari, com pequenas vielas e quadras irregulares (foto 5), e o parcelamento em forma de arco, inserido entre as ruas Rio Bonito, Paraíba e Carlos de Campos, com características predominantemente residenciais, de padrão superior às outras do bairro.

A estrutura territorial de São Paulo já era formada em 1950, quando o centro histórico foi integrado por uma coroa de bairros. Diz Seabra:

A Cidade de São Paulo chegou a sua mais exuberante forma nos anos 1950 quando, nitidamente integrada por uma coroa de 
bairros, foi ficando imersa num processo de implosão-explosão para as periferias (SEABRA, 2004: 271).

Nessa época a cidade já começava a implodir, extrapolando para a periferia e dando a configuração atual da metrópole. Até hoje há uma diferença clara entre os bairros centrais, estruturados numa época em que era possível a vida cotidiana nos bairros, e os bairros periféricos, formados após a consolidação da metrópole, do estágio fordista do capitalismo (idem: 281).

Foi apenas depois de 1954 que o bairro do Canindé se tornou realmente ocupado. O Campo da Força Pública (Academia da Polícia Militar), até então vazio, aparece, a partir dessa data, tomado por algumas edificações. Encontravam-se também habitadas as transversais à Rua do Canindé, como as ruas Vidal de Negreiros, Afonso Arinos e Pasteur. Todas dominadas por habitações populares que ao longo dos anos foram sendo transformadas em cortiços ou imóveis abandonados (foto 6).

\section{Foto 6 - Rua Vidal Negreiros}
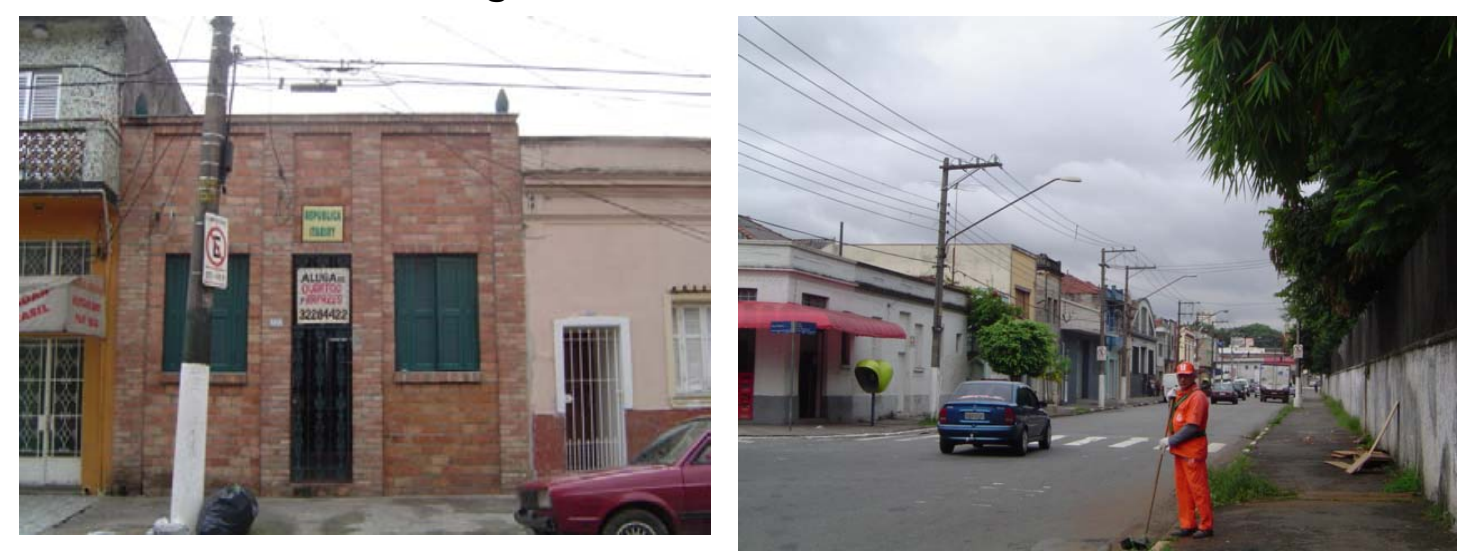

Até 1964, a área total do distrito do Pari era de 5,46 km² (abrangia então a Vila Guilherme). Hoje o distrito possui $2,9 \mathrm{~km}^{2}$, limitando-se à margem esquerda do rio Tietê.

A ocupação do Pari foi uma mescla de residências com indústrias de pequeno e médio porte e área comercial com predominância do ramo de confecções. As habitações ocupavam em geral lotes pequenos, onde se 
enfileiravam casas semelhantes, sem jardim nem quintal, numa repetição contínua e monótona. O sobrado que incluía salão comercial no térreo e residência no andar superior foi também uma tipologia disseminada. Os cortiços foram surgindo a partir de adaptações, mas vários outros foram construídos para esse mesmo fim. Em alguns pontos do bairro, principalmente nas ruas próximas à Praça Padre Bento, é possível encontrar residências implantadas em lotes de maiores dimensões, com recuos frontais e laterais, e com jardins.

\section{2. b. História social}

\section{I - Tradições}

A origem da cidade se confunde com a origem da sociedade de classes, mesmo que esta a tenha precedido; portanto, é o lugar da sede do poder e da classe dominante. Assim, não é possível estudar a metrópole paulistana, sem focalizar as ações da classe dominante brasileira, ressaltando a importância de São Paulo como o maior centro urbano do Brasil e da América do Sul.

Qual é o papel social desenvolvido pelo Pari na estruturação da metrópole paulistana? Qual a sua relação com o centro? Como os moradores construíram esse espaço e como esse espaço construiu o morador, o social?

$\mathrm{Na}$ história contada por seus moradores, o Pari começou a se formar por volta de 1576. Seu aniversário é comemorado na data de 9 de novembro, data esta "inventada" e oficializada pela Portaria n 165/76 da Secretaria Municipal de Cultura - PMSP, no 400 aniversário do bairro. Atribui-se o germe da invenção dessa data ao decreto municipal $n^{\circ} 9.051$ de 12/10/70, que motivou, em 1972, a necessidade das fundações dos bairros.

Desse modo, inventando tradições, se perpetua na memória a vida de um bairro. As tradições tornam-se importantes devido ao papel que as ideologias desempenham na formação da cultura. Além disso, muitas das 
"invenções" são criadas com o objetivo de justificar as ações dos vencedores (HOBSBAWN, 2002). Assim, é significativo que os bairros mais populares se orgulhem de ter uma data de fundação. Os aniversários são momentos da possibilidade de festa, de agregação e de troca. É curioso o esforço de inventar o nascimento de um loteamento. Recorre-se em geral à história que os moradores antigos contam ou criam sobre as primeiras ocupações.

Das atividades sociais do bairro destaca-se a aglutinação que exerce a Igreja de Santo Antônio do Pari, não só entre os moradores do bairro como entre os fiéis do município todo.

Na Praça Padre Bento, mais conhecido como Largo Santo Antônio encontra-se a Igreja de mesmo nome, fundada em 1911 (Foto 4), construída por uma ação entre doadores das colônias italiana e portuguesa (AMADIO, 2004).

A Igreja de Santo Antônio tem um grande significado para o Pari, sobretudo para os fiéis católicos, que são em grande número na região; para os não-católicos, ela representa uma referência simbólica do bairro. A comemoração do dia de Santo Antônio (13 de junho), com a distribuição de pão bento, pode ser considerada, também, outra invenção, de tempos mais ou menos recentes, como a já referida data de aniversário do bairro. O responsável pela paróquia em 1976, Frei Aécio (Diário Popular, 1976), disse que a fama de Santo Antônio como santo casamenteiro não passava de uma lenda. Mas a lenda atravessou séculos e sobreviveu em terras do além-mar. No dia do santo, a procissão concentra cerca de 30 mil fiéis. A reza e a festa aparecem unidas com o passar do tempo. A Igreja faz do bairro uma extensão do seu espaço sagrado, visando organizar a vida de seus moradores. A respeito desse papel da Igreja, diz Seabra:

Em conseqüência, se verá que o catolicismo romano chegou a ser vivido como um atributo da cultura e assim o foi porque era uma doutrina que se transformava como uma prática capaz de organizar a vida modulando o uso do tempo. De um ponto de vista teórico, dir-se-ia que a religião integra a práxis sustentando representações e práticas do estar no mundo. E que a alienação religiosa por não ser apenas ideologia, integra de modo 
estruturantes os modos de ser, impregnando-os de significação e de sentidos práticos (SEABRA, 2003:235).

O culto dos santos no catolicismo luso-brasileiro é muito forte, com firme devoção àqueles que favorecem a prática do fortalecimento das paróquias, pela qual se realiza a centralidade da Igreja em cada localidade. A imagem da Igreja de Santo Antônio (foto 7) destaca a representatividade do bairro do Pari na metrópole.

Foto 7 - I greja Santo Antônio (antes e depois de queimar uma torre 2007)
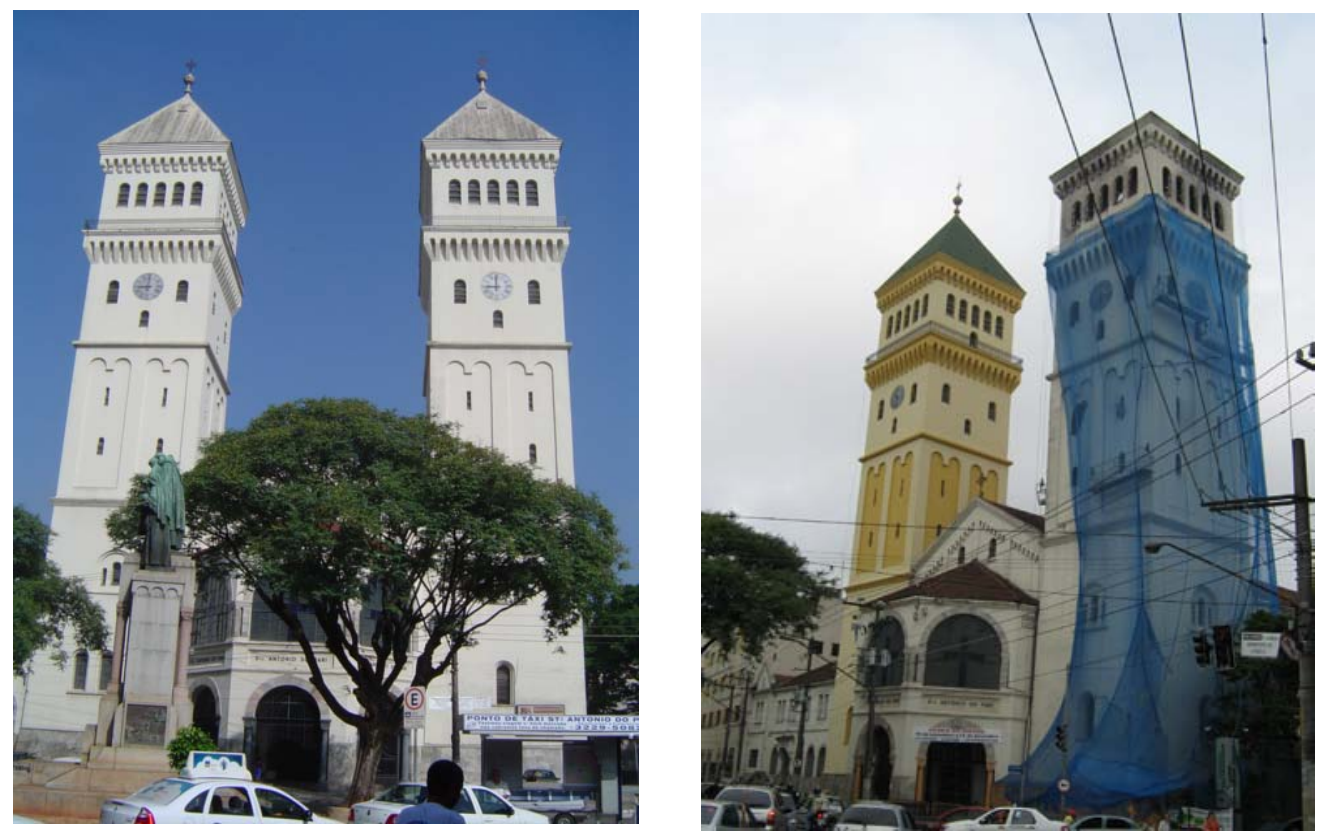

A igreja de Santo Antônio do Pari foi vítima de um incêndio em 2007, em decorrência do número de velas acesas no dia do santo padroeiro, e teve uma de suas torres completamente danificada. Restou apenas uma torre, ficando assim parcialmente destruído o símbolo do bairro.

Assim como a religião, a prática esportiva, principalmente o futebol, teve grande importância na agregação social do bairro, que contava com 
muitos times de futebol de várzea, em razão da grande extensão de áreas planas e baixas. É bom lembrar que foi em torno da Ponte Pequena que nasceram os grandes clubes esportivos no começo do século $X X$, como 0 Espéria e o Tietê, que permanecem ainda no mesmo lugar, embora o rio tenha mudado de contorno e não passe mais pelos clubes. O principal esporte, então, era o remo, e as competições de davam no rio Tietê, com espectadores nas margens e também sobre a Ponte Grande. Os clubes de futebol de várzea foram implantados nas áreas baixas do rio Tamanduateí e Tietê, a partir de 1919, como o Estrela do Pari (Foto 8), antigo Clube União dos Vaqueiros, o Serra Morena (1929), o Esporte Clube Vigor (1924) e, apenas em 1956, a Portuguesa de Desportos, instalada na Marginal Tietê com Rua Azurita. Esse clube representa uma extensão da comunidade lusobrasileira, que aí se reúne para a prática de esporte e reuniões familiares e com amigos.

\section{Foto 8 - Clube Estrela do Pari}

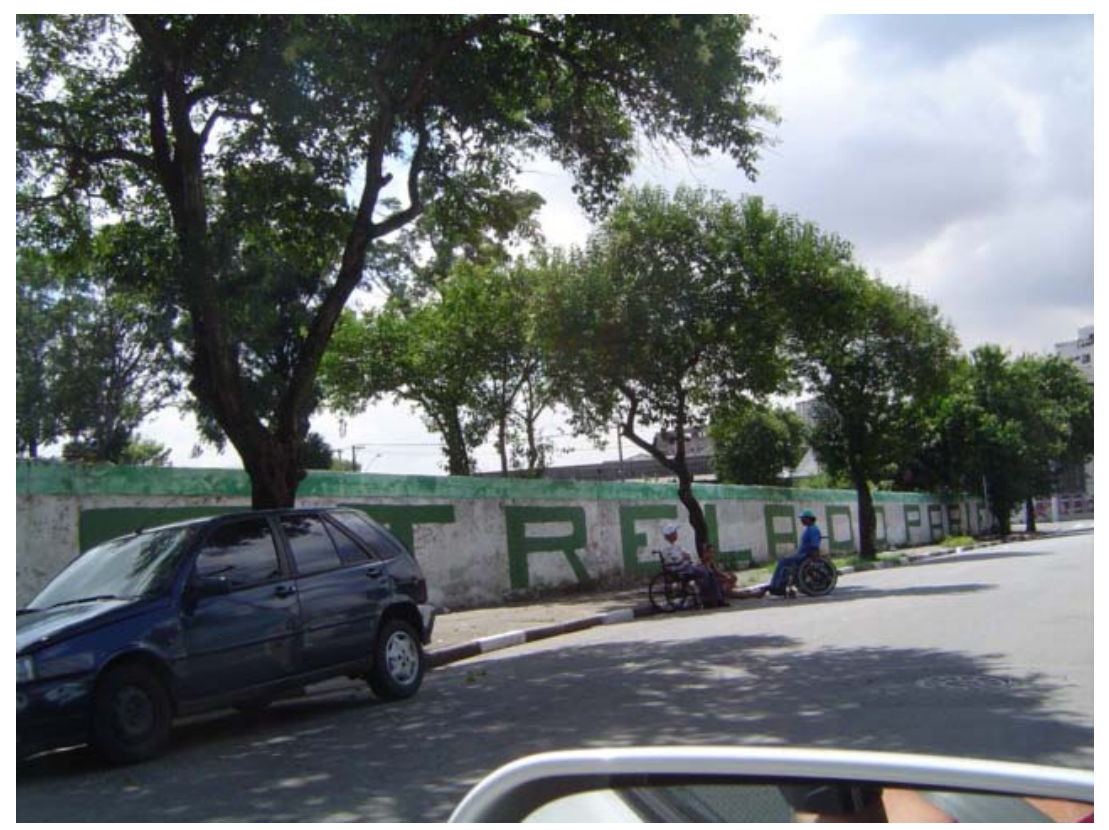

Os clubes de várzea tiveram importância muito grande na formação cultural e na agregação da população paulistana no começo do século XX, início da sociedade industrial. O futebol de várzea fomentou uma prática que depois derivou para a profissionalização, com especialização de funções e racionalização técnica. 
O discernimento de algumas das implicações desse futebol no processo de industrialização-urbanização de São Paulo interessa à temática da vida do bairro porque estas práticas inseriam-se no cotidiano do bairro e o preenchiam de conteúdos significativos (SEABRA, 2003: 268).

Esse futebol de várzea de São Paulo pode ser entendido como a primeira grande festa do povo fora da perspectiva da Igreja. Não obstante, tanto as paróquias como os colégios católicos, empreenderam grandes esforços para assimilar os impulsos que vinham do futebol, e até conseguiram, em muitos casos, seus intentos. Foi como conjunto de práticas lúdicas, definidas como âmbito próprio, como coisa do povo que, paradoxalmente, a Igreja, imiscuindo-se nelas, visava dar continuidade às suas práticas paroquiais (idem: 270).

A popularização do futebol fez a sociabilidade de famílias, pois, apesar do caráter masculino do jogo, as mulheres estavam sempre presentes na torcida. Nem todos viam com bons olhos as práticas do futebol. Muitos anarquistas e comunistas da época o consideravam outro "ópio do povo". Mas, como o futebol teve grande aceitação nos bairros operários e se multiplicavam os times de fábrica, acabou sendo reconhecido como uma forma de organização eficiente (idem).

Além das atividades sociais e esportivas, a prática política sempre foi uma ação gregária e/ou dispersiva na vida dos moradores do bairro. O Pari teve uma ativa participação na Revolução de 1924. No Pari e no Canindé, mais especificamente na Avenida Vautier, $n^{\circ} 27$, reuniam-se conspiradores para definir a forma de combate ao governo do presidente Arthur Bernardes. O bairro sofreu muitos prejuízos com a batalha, que persistiu por 25 dias, matando aproximadamente 600 pessoas e deixando cinco mil feridos na cidade de São Paulo (Folha de São Paulo, 1976).

Antes de 1950, o cotidiano dos bairros era vivido entre o trabalho e a casa; as funções de comércio e de serviço especializado eram desempenhadas no centro (idem, 2004: 293). Hoje, é possível encontrar muitos serviços e comércios nos bairros. A diferença entre o centro da 
cidade e os bairros fabris e de moradia era nítida. O bairro estava inserido no tempo lento da urbanização. Os bairros operários de São Paulo eram povoados por imigrantes ou filhos de imigrantes, todos pobres. O bairro pobre

teve por muito tempo os estigmas invisíveis da disfarçada servidão na personalidade (MARTINS, 2007:2).

As práticas de cada lugar levam a diferentes construções sociais. Essas práticas incluem o jeito de ser, características do meio, oportunidades de aprendizado e formas de como se responde emocionalmente aos fatos. A totalidade não é a soma das partes, mas o movimento de todos esses fenômenos. É a cultura que atribui valores às coisas e ao lugar. O espaço, consequência da prática social, da cultura, o espaço de uma relação com o outro como ser social, exige um tratamento especial. Sair de casa, andar pela rua, é realizar um ato cultural, não arbitrário: insere o habitante em uma rede de sinais sociais que the são preexistentes (os vizinhos, a configuração dos lugares, a paisagem) (PACCA, 2004:67).

\section{I - I migração}

Os primeiros moradores da área do Pari, índios, escravos e portugueses, dedicavam-se à pesca, utilizando um antigo método: com uma cerca de taquara ou cipó, denominada "pari", atravessavam o rio de margem a margem, bloqueando a passagem dos peixes. Posteriormente a pesca deixou de ser a ocupação principal, e a área foi usada para criação de gado e caça a cabritos e frangos d'água; e, mais tarde, como portos de areia.

A história do distrito do Pari está calcada nos seus imigrantes, suas profissões e atividades. Não é possível falar do bairro sem falar das inúmeras etnias que acolheu. 
O bairro do Pari se inscreveu na história social da metrópole paulistana como um bairro operário. Sua população foi inicialmente formada por portugueses e italianos. Depois da década de 1950, com o crescimento das indústrias e do comércio da região, vieram imigrantes de diversas outras nacionalidades: árabes, espanhóis, judeus, armênios, gregos, chineses e japoneses. Na década de 1980, começaram a chegar os coreanos, os bolivianos e os paraguaios. O distrito é composto basicamente pelos descendentes desses imigrantes, além de apresentar migrantes nordestinos, que na década de 1970 também procuraram o bairro para morar, sobretudo os cortiços.

A etnia é um fator de agregação no distrito do Pari. Os portugueses foram os mais numerosos habitantes estrangeiros, seguidos dos italianos. Hoje, são seus descendentes que predominam.

Os portugueses são os maiores proprietários de imóveis registrados à pessoa física do distrito. Os italianos aparecem em segundo lugar em número de habitantes e em número de propriedades de imóveis de pessoa física. O maior proprietário individual é um árabe. Dos espanhóis, judeus, armênios, gregos, chineses e japoneses pouco a salientar sobre seus descendentes. Dos judeus, pode-se salientar que, assim como os árabes, não deixam seus imóveis vazios, sem utilização (afirmação unânime dos entrevistados). Preferem alugar por um preço abaixo do de mercado a deixar o imóvel parado, como o fazem os portugueses. Dos chineses notou-se que são, na grande maioria, comerciantes. Na realidade, todos os proprietários estrangeiros são em geral comerciantes ou industriais.

Os coreanos têm uma importância especial entre os estrangeiros por terem chegado mais tarde, na época em que o bairro já estava formado, estruturado e apresentando certa decadência. Havia coreanos em São Paulo desde 1950, mas em 1980 verificou-se uma imigração em massa. Vieram com o objetivo central de investir no bairro, tanto na produção como na renovação dos imóveis. Estabeleceram-se primeiro na Liberdade, depois no Bom Retiro e no Brás, e em 1990 descobriram o Pari - em outro momento, os que melhoram de vida deslocam-se para Vila Mariana e Vila Madalena. A presença cada vez mais crescente dos coreanos no Pari é visível: nos ideogramas, em mulheres, homens e crianças de olhos puxados nas ruas, 
nas escolas coreanas, em várias confecções e restaurantes coreanos, na acupuntura coreana e na prática do tai chi. Eles começaram a mudar a fisionomia do bairro.

Enquanto os portugueses e seus descendentes jamais fazem recuperação em seus imóveis, a característica marcante dos coreanos é oposta: fazem grandes reformas, modernizam os imóveis e mudam a paisagem - conduta essa que, na visão de moradores, tem inflacionado o precário mercado imobiliário do Pari. Além disso, estão diversificando as atividades do bairro, abrindo restaurantes, mercadinhos, livrarias, locadoras de vídeo - onde é possível encontrar filmes e novelas coreanas -, salões de beleza, peixarias. Acredita-se que $10 \%$ da população coreana de São Paulo esteja no Pari ( 3 mil entre 35 mil).

Dos estabelecimentos comerciais e industriais instalados no Pari, a estimativa é que os coreanos sejam proprietários de $30 \%$ das confecções e $50 \%$ das lojas da Rua Silva Telles (entrevista). A “invasão coreana" dinamizou o velho comércio e fez com que sobrados e casarões antigos ganhassem cotação em dólar. Seus estabelecimentos se localizam numa parte do Pari, a parte onde se tem verificado uma ruptura com a estagnação e imobilização do bairro. As luvas chegam a 100 mil dólares, os aluguéis para lojas subiram e não se encontram pontos para novas lojas. Por que os coreanos deram preferência ao Pari? Provavelmente pela proximidade em relação ao Centro e, apesar disso, pela tranquilidade do bairro, que se contrapõe à promiscuidade e à saturação das fábricas do Bom Retiro e do Brás.

A vinda dos coreanos para o Brasil se deu de forma organizada pela Igreja Presbiteriana Coreana, como relatou em entrevista o Sr. André King ${ }^{4}$. Os interessados em vir ao Brasil são financiados por um grupo da Igreja, que cuida de suas vindas, sustentando-os e financiando seus negócios por um determinado tempo e provendo a escolaridade de seus filhos. A Igreja elabora uma ação como se fosse um consórcio no qual os interessados em "investir" em seus conterrâneos financiam, com contribuições mensais, a

${ }^{4}$ Empresário do ramo de confecções instalado na área desde 1980, que no início de sua imigração morou com a família no Pari, e hoje, mora na vila Mariana, mas ainda toca uma confecção e um comércio no bairro. 
vinda e a permanência dos imigrantes. Essa iniciativa da Igreja se dá desde a vinda dos primeiros imigrantes até hoje. Ela acompanha a vida de seus membros e, quando aquele que é ajudado passa a poder ajudar, ele se transforma de recebedor em financiador. Por um lado a Igreja dá oportunidade de ascensão econômica e por outro controla a vida dos fiéis. 0 dinheiro dos coreanos dinamizou o bairro. Se existe o Capital, mas não o disponibiliza no espaço, como o fazem os antigos moradores do bairro, essa imobilidade do Capital reflete no espaço.

Hoje, os coreanos, em geral, quase não moram mais no bairro, diferentemente dos antigos donos de confecções e industriais de ascendência italiana, portuguesa ou sírio-libanesa (Estadão, 1990).

Foto 9 - Igreja Presbiteriana e clínica de acupuntura coreanas
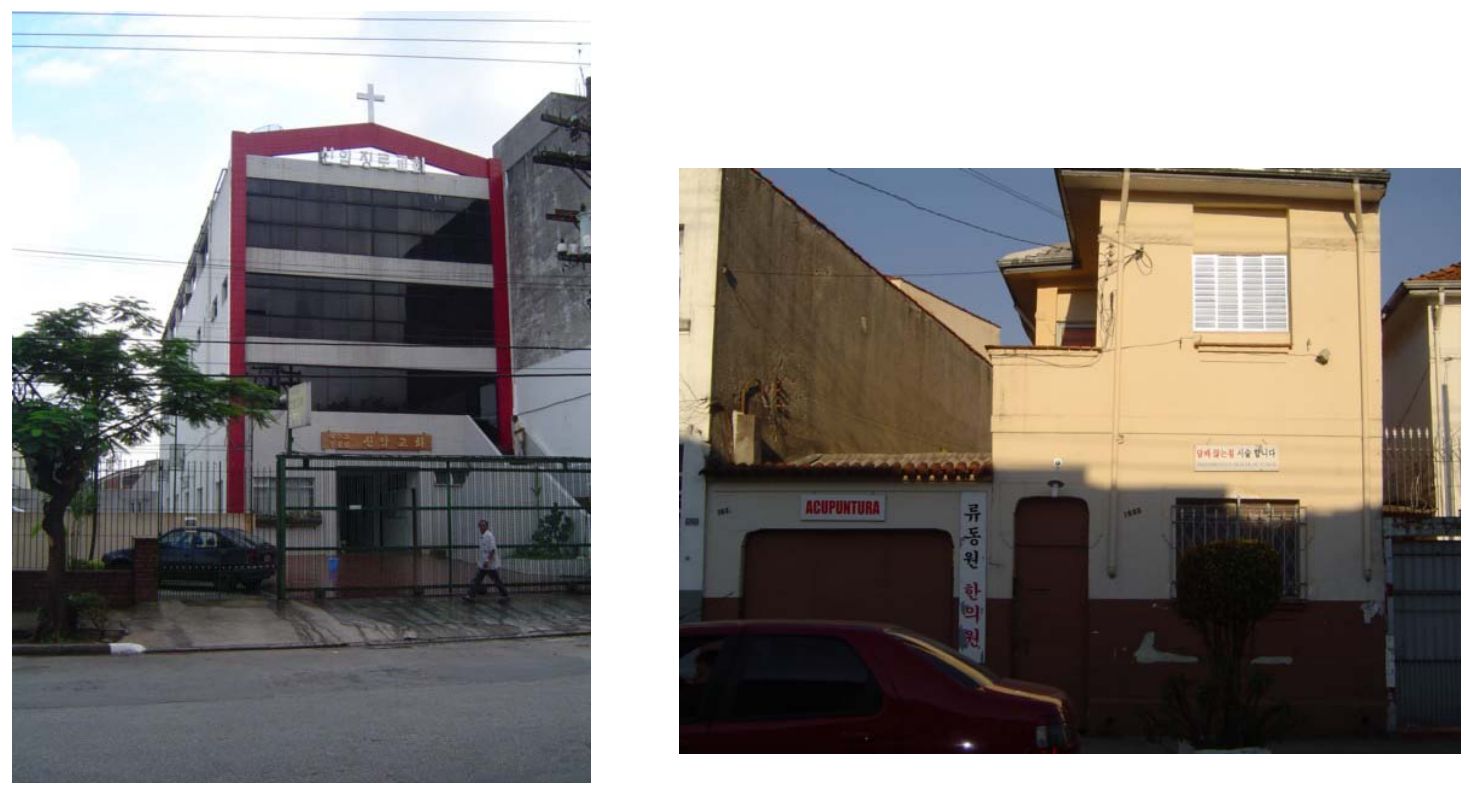

O distrito do Pari acolheu também um número muito grande de bolivianos e alguns paraguaios, que vivem em condição desumana. O sonho boliviano de vir ao Brasil é antigo e se assemelha ao de muitos imigrantes pelo mundo: tentar uma mobilidade econômica e um reconhecimento social num país estrangeiro.

A imigração boliviana vem desde 1950, quando eles se dirigiam ao Brasil com o objetivo de estudar pelo Programa Cultural Brasil-Bolívia e 
muitos optavam por permanecer aqui. A partir de 1980, verifica-se uma nova forma de imigração: a vinda ao Brasil em razão da maior oferta de empregos que em sua terra natal, ou pela ilusão de que aqui, principalmente na cidade de São Paulo, seja mais fácil e rápido acumular um capital que permita abrir um negócio próprio. Em geral, são pessoas de ambos os sexos, solteiros, de escolaridade média. Chegam para trabalhar em regime de produção por peças em indústrias de confecção de coreanos, bolivianos e brasileiros. Vivem no início de maneira muito difícil, explorados pelos empregadores, que se aproveitam de sua condição de indocumentados. Sujeitam-se a não receber salário, trabalhando muitas vezes em troca apenas de cama e comida, sonhando em um dia ter sua própria oficina de costura. Os que conseguem ganhar algum dinheiro mandam pelo menos US\$100,00 por mês para familiares na Bolívia. Alguns almejam largar o trabalho de costura e estudar para mudar de profissão. Outros, ainda, já estabelecidos, investem em uma atividade econômica que complemente a renda do emprego nas oficinas de costura, e aproveitam a feira na Kantuta ${ }^{1}$ (foto 10) para vender seus produtos. Apesar da condição sujeitada e do preconceito que sofrem social e culturalmente, os bolivianos se organizam em Associações, que proporcionam esperança de mobilidade social e econômica (SILVA, 2006).

Foto 10 - Praça Kantuta e Shopping Pari
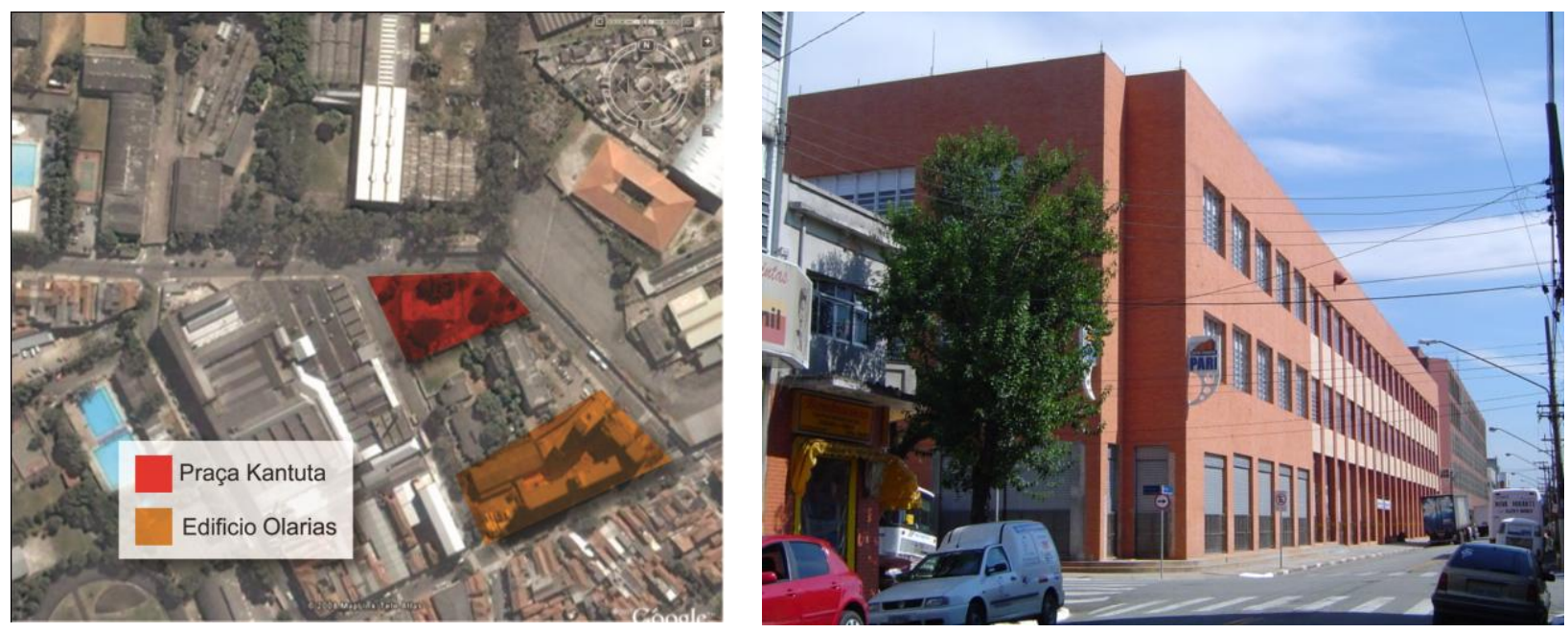

${ }^{1}$ Kantuta é uma praça do Pari, na Rua das Olarias, onde aos domingos acontece a feira com atrações culturais bolivianas. Kantuta é uma flor do altiplano boliviano. 


\section{I - Vulnerabilidade social}

O índice de expectativa de vida face à violência, às condições de acesso a serviços básicos de saúde e à renda tem vulnerabilidade alta na área do Canindé e, no Pari, vulnerabilidade média. Há uma homogeneização socioeconômica (SEADE, 2008).

Tomamos os registros de homicídios como indicadores importantes sobre a violência (SEADE, SEMPLA, 2008) - são crimes menos propensos a subnotificações, além de serem, devido a sua gravidade, mais confiáveis do ponto de vista do registro.

O mapa (mapa 11) indica o risco de homicídio doloso no município de São Paulo entre 2000 e 2005. Nota-se que os pontos de maior risco apresentam-se nas extremidades do município e na área central, com destaque nítido no distrito do Pari.

Além de o índice de violência registrado ser um dos mais altos do município, são frequentes nos jornais as notícias negativas, ligadas a contravenções: inúmeras apreensões de cargas ilegais; fechamento do Shopping Pari devido aos produtos piratas à venda e a consequente prisão de seu proprietário; violências urbanas corriqueiras; caminhões utilizando as largas ruas como estacionamento etc.

No entanto, a violência urbana é generalizada no município. O isolamento de grupos de iguais, os guetos urbanos, os shopping centers, os condomínios fechados produzidos por essa sociedade desigual, são frutos e promotores da exclusão. A solidariedade está em decadência na sociedade atual e os valores dos jovens são cada vez mais determinados pela ilusão do consumo.

Portanto, é difícil assegurar que essa desmobilização faz parte da situação específica do bairro. Seguramente, podemos concordar que o momento atual não está propiciando às organizações atuações efetivas, dada a insistente propaganda por soluções individuais e a própria decadência da vida política no país. A fase atual do capitalismo estimula o individualismo exacerbado, a concentração de poder, a expansão desregulada do mercado. 
O sistema de gestão da cidade não se resume à sua estrutura, mas sim às suas prioridades sociais e morais.

A vida social hoje do bairro é pautada por pouca organização. As entrevistas com moradores e frequentadores relataram que os movimentos sociais deixaram de ter a atuação de anos anteriores. A Sociedade Amigos do bairro do Pari é a principal porta voz de reivindicações. Outras entidades que atuam em setores específicos são ligadas às igrejas ou aos emigrantes. 


\section{Mapa 11 - homicídios dolosos - MSP}

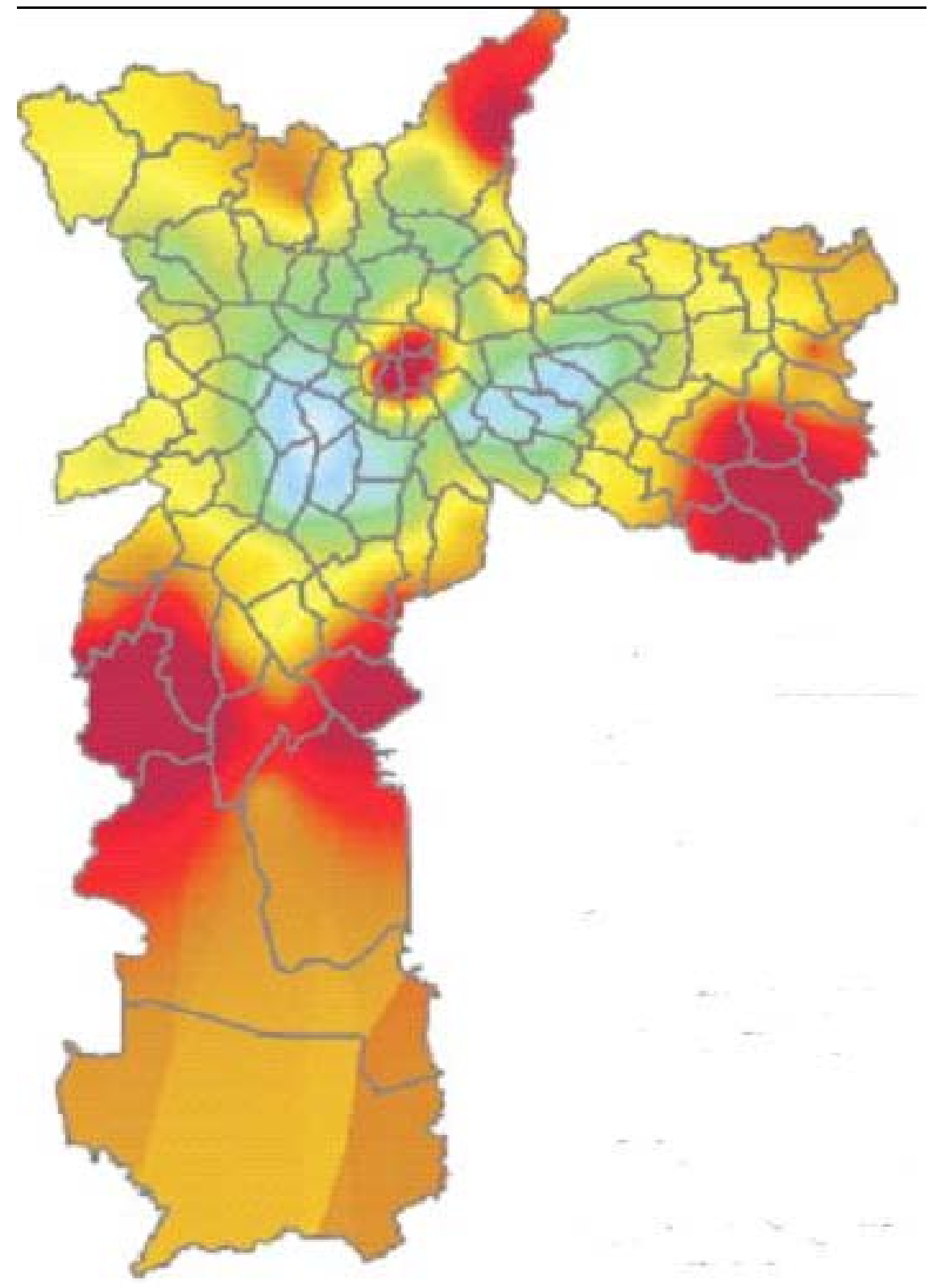

Risco de registro de ocorrência

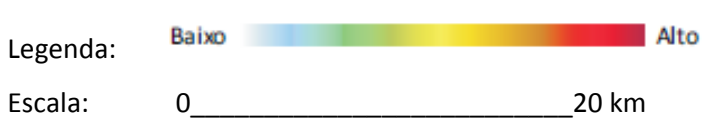

Fonte: Secretaria de Segurança Pública do Estado de São Paulo SSP-SP/Coordenadoria de Análise e Planejamento - CAP. Número de homicídios dolosos por distritos policiais; Fundação Sistema Estadual de Análise de Dados - Seade. Número de residentes por distritos policiais.

DIPRO/SMDU/PMSP 


\section{2. c. A história demográfica}

\section{I - Demografia}

O censo realizado em 1765 registrava, no Pari, a presença de 14 casas de sapé e 72 habitantes (FRANCOLINO, 1979). Esses números certamente não demonstram que se tratava de uma aglomeração urbana importante, embora, para seus moradores, tenha o significado especial de mostrar a antiguidade do bairro.

As pesquisas que efetuamos para analisar a demografia do distrito foram recolhidas de dados oficiais do Instituto Brasileiro de Geografia e Estatística (IBGE), provenientes dos Censos Demográficos realizados a cada dez anos em todo o território nacional. Assim como do Censo de 1991, feito com um ano de atraso, dos estudos e pesquisas da Fundação Sistema Estadual de Análise de Dados (SEADE) e das estimativas populacionais do Departamento de Estatística e Produção de Informação (DIPRO) da Secretaria Municipal de Planejamento (SEMPLA/PMSP, 2006).

As retroestimativas populacionais para o Município e Distritos Municipais (Tabela 2), anos de 1950, 1960, 1970 e 1980, são resultado de um processo que teve como base os antigos distritos e subdistritos da capital e que levou em conta a história de cada distrito. Os dados mostram que o centro expandido perdeu 309 mil habitantes nos últimos 14 anos (SEADE). Mais da metade dos 96 distritos (52) da capital paulista, a maior parte na região central, registrou redução demográfica. A tendência se verifica desde 1991, em projeções do SEADE com base nos dados dos censos demográficos do IBGE. 
Tabela 2 - População e Taxa de Crescimento - 1950 a 2000

\begin{tabular}{|c|c|c|c|c|c|c|c|c|c|c|c|}
\hline \multicolumn{12}{|c|}{ População nos Anos de Levantamento Censitário e Taxa de Crescimento } \\
\hline \multirow{2}{*}{$\begin{array}{l}\text { Unidades } \\
\text { Territoriais }\end{array}$} & \multicolumn{6}{|c|}{ População } & \multicolumn{5}{|c|}{ Taxa de Crescimento } \\
\hline & 1950 & 1960 & 1970 & 1980 & 1991 & 2000 & $50 / 60$ & $60 / 70$ & $70 / 80$ & $80 / 91$ & $91 / 00$ \\
\hline MSP & 2.151 .313 & 3.667 .899 & 5.924 .615 & 8.493 .226 & 9.646 .185 & 10.434 .252 & 5,48 & 4,91 & 3,67 & 1,16 & 0,88 \\
\hline Pari & 31.312 & 33.706 & 29.914 & 26.968 & 21.299 & 14.824 & 0,58 & $-1,06$ & & $-2,12$ & $-3,95$ \\
\hline Sé & 30.022 & 32.343 & 29.555 & 32.965 & 27.186 & 20.115 & 0,59 & $-0,77$ & 1,13 & $-1,74$ & $-3,29$ \\
\hline República & 35.994 & 48.346 & 50.348 & 60.999 & 57.797 & 47.718 & 2,83 & 0,53 & 1,97 & $-0,49$ & $-2,11$ \\
\hline Belém & 56.722 & 62.881 & 60.031 & 57.195 & 49.697 & 39.622 & 0,88 & $-0,34$ & $-0,45$ & $-1,27$ & $-2,49$ \\
\hline Brás & 55.097 & 48.875 & 41.006 & 38.630 & 33.536 & 25.158 & $-1,35$ & $-1,62$ & $-0,56$ & $-1,28$ & $-3,14$ \\
\hline Bom Retiro & 45.880 & 53.893 & 45.662 & 47.588 & 36.136 & 26.598 & 1,46 & $-1,52$ & 0,44 & $-2,47$ & $-3,35$ \\
\hline Sta Cecilia & 63.460 & 80.581 & 83.075 & 94.542 & 85.829 & 71.179 & 2,26 & 0,43 & 1,33 & $-0,88$ & $-2,06$ \\
\hline Consolação & 38.228 & 52.182 & 60.600 & 77.338 & 66.590 & 54.522 & 3 & 1,63 & 2,5 & $-1,35$ & $-2,2$ \\
\hline Bela Vista & 46.340 & 57.364 & 64.704 & 85.416 & 71.825 & 63.190 & 2 & 1,34 & 2,85 & $-1,56$ & $-1,41$ \\
\hline Cambuci & 35.499 & 39.789 & 39.727 & 44.851 & 37.069 & 28.717 & 0,99 & 0,11 & 1,25 & $-1,72$ & $-2,8$ \\
\hline Liberdade & 55.523 & 68.210 & 71.503 & 82.472 & 76.245 & 61.875 & 1,92 & 0,6 & 1,47 & $-0,71$ & $-2,29$ \\
\hline
\end{tabular}

Fonte: IBGE (SEMPLA/DIPRO) PMSP 2008

O Pari é, entre todos os distritos do município de São Paulo, o que mais perdeu população desde 1970, em termos relativos. O distrito do Brás começou a perder primeiro, em 1950, mas em termos relativos, perdeu menos que o Pari.. De 1950 a 1960 a cidade de São Paulo apresentou um aumento de população, com exceção dos distritos do Brás e do Pari. Até a década de 1970, os distritos centrais representavam a maior população em números absolutos. Depois começou a se verificar uma inversão: os distritos mais extremos - ao norte, ao sul e a leste - passaram a concentrar um maior contingente demográfico. A maior taxa de crescimento negativo foi entre 1991 e 2000, período em que todos os distritos centrais tiveram perda de população. Embora essa perda tenha sido generalizada, os distritos localizados na direção do vetor ${ }^{1}$ oeste perderam menos que aqueles situados no centro-centro (Sé), centro-norte (Pari) e centro-nordeste (Brás). Portanto, desde 1970, o Pari vem perdendo população acentuadamente.

A população do Pari é de 14.824 (Censo 2000, IBGE), em 6.345 imóveis, e a projeção para 2006 é de 15.417 habitantes (SMDU/DIPRO), o que não significa perda em números absolutos, mas sim na porcentagem de crescimento. No entanto, como é uma projeção estatística, não se pode

\footnotetext{
${ }^{1}$ Segmento de reta orientado.
} 
confiar plenamente. A população, entre 1991 e 2000, teve um decréscimo de mais de $50 \%$.

A causa da perda de população pode estar na saída dos mais jovens, longevidade e melhor padrão de vida geral da população, diminuição do processo migratório, queda da taxa de mortalidade e redução da taxa de fecundidade (SEADE, 2008). O SEADE sustenta que essa perda se dá pelo fato de a área estar saturada e não permitir um maior adensamento (Folha de São Paulo, 13/08/2008). Esse argumento parece equivocado, porque o Pari é praticamente horizontal, existindo, portanto possibilidade de verticalização e o consequente adensamento populacional. A nosso ver, sua pouca densidade populacional - 50 habitantes por hectare - reflete a falta de interesse do mercado imobiliário em investir no bairro. Uma das causas para a diminuição da população reside no que parece ser um paradoxo dentro da lógica do mercado: apesar de ter menos de $50 \%$ dos imóveis alugados e um mercado imobiliário, pelo menos o de vendas, pouco animado, muitos deixam o Pari em razão dos altos preços dos aluguéis, sendo obrigados a procurar moradia na periferia (GLOBO, 2006).

\section{II - Renda}

A situação financeira dos moradores do distrito do Pari aparece entre os três mais pobres dos distritos da área central, sendo ultrapassado apenas pelo Brás e a Sé. A população é composta de $10 \%$ na faixa salarial maior que 10 salários mínimos e $10 \%$ na faixa salarial com menos de 3 salários mínimos. Portanto, $80 \%$ possuem renda na média salarial entre 3 e 10 salários mínimos (Tabela 3). 
Tabela 3 - Renda dos responsáveis do Distrito do Pari - 2000

\begin{tabular}{lcccccccc} 
& \multicolumn{9}{c}{ Renda dos responsáveis } & & \\
& Total & S/ Rrenda & Até 3 sm & 3 a $5 \mathrm{sm}$ & 5 a $10 \mathrm{sm}$ & 10 a 20 & Mais de 20 \\
Total & 4408 & 254 & 1066 & 849 & 1200 & 718 & 321 \\
Homens & 2898 & 167 & 537 & 544 & 838 & 538 & 274 \\
Mulheres & 1510 & 87 & 529 & 305 & 362 & 180 & 47
\end{tabular}

Fonte: IBGE (SEMPLA/DIPRO) PMSP 2008

\section{III - Faixas etárias}

O distrito apresenta aumento no índice de envelhecimento da população, ou seja: maior quantidade de idosos com 65 anos e mais em relação ao total de crianças de 0 a 14 anos (Tabela 4 e 5). Há outros distritos no qual o índice de envelhecimento é maior que no Pari, como Moóca, Bela Vista, Cambuci, Consolação e Santa Cecília. O envelhecimento é uma estimativa geral do município, diante do aumento da expectativa de vida (SEMPLA/DIPRO). Entre os idosos a população feminina é maioria, como acontece na média do município paulistano.

Tabela 4 - População Residente por Faixa Etária

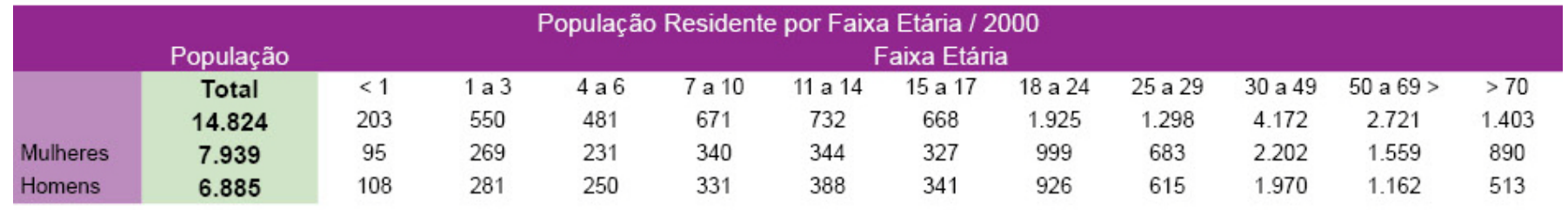

Fonte: SEMPLA/DEINFO, 2008 
Tabela 5 - Indice de Envelhecimento por Sexo Município de São Paulo

e Distritos Centrais Municipais - 1991 - 2000

\begin{tabular}{lccccccc}
$\begin{array}{l}\text { Unidades } \\
\text { Territoriais }\end{array}$ & \multicolumn{7}{c}{ Índice } \\
& Total & Homem & Mulher & Total & Homem & Mulher \\
Belém & $\mathbf{5 3 , 8 7}$ & 37,39 & 71,39 & $\mathbf{9 3 , 9}$ & 51,32 & 97,22 \\
Brás & $\mathbf{3 2 , 4 9}$ & 25,52 & 39,51 & $\mathbf{3 6 , 2 9}$ & 26,5 & 46,95 \\
Moóca & $\mathbf{5 8 , 3 3}$ & 43,92 & 73,08 & $\mathbf{9 3 , 2 3}$ & 67,91 & 119,45 \\
\hline Pari & $\mathbf{4 5 , 0 7}$ & 33,06 & 58,04 & $\mathbf{7 6}$ & 55,15 & 98,12 \\
\hline Bela Vista & $\mathbf{5 2 , 4 2}$ & 36,12 & 69,23 & $\mathbf{8 1 , 0 7}$ & 53,34 & 109,14 \\
Bom Retiro & $\mathbf{4 3 , 1 6}$ & 34,91 & 51,44 & $\mathbf{5 1 , 2 3}$ & 36,99 & 66,81 \\
Cambuci & $\mathbf{4 9 , 7 7}$ & 36,91 & 63,07 & $\mathbf{7 8 , 8}$ & 55,06 & 103,4 \\
Consolação & $\mathbf{8 3 , 1 3}$ & 62,95 & 102,64 & $\mathbf{1 3 2 , 5}$ & 94,03 & 171,44 \\
Liberdade & $\mathbf{4 3 , 2 7}$ & 32,92 & 53,63 & $\mathbf{6 7 , 1 4}$ & 47,08 & 87,48 \\
República & $\mathbf{5 3 , 3 6}$ & 40 & 66,73 & $\mathbf{6 6 , 8 3}$ & 49,56 & 84,05 \\
S. Cecília & $\mathbf{6 0 , 2 2}$ & 42,32 & 78,6 & $\mathbf{8 4 , 5 2}$ & 57,89 & 111,25
\end{tabular}

Fonte: SEMPLA/DEINFO, 2008

No Pari, a população feminina é um pouco maior que a masculina (tabela 4). A faixa etária predominante é entre 30 e 49 anos (tabela 4), mas também é numerosa a faixa entre 50 e 69 anos. Também não se pode desprezar a faixa dos maiores de 70 anos, que ultrapassa a faixa dos jovens. Pode-se portanto afirmar que o Pari é um distrito de pessoas mais idosas. Qual a análise possível a partir desses dados? Pode-se perceber que os jovens, quando se emancipam, saem do distrito e as pessoas com estabilidade econômica preferem continuar no bairro; ou, e aqueles que não obtiveram ascensão econômica não se permitem sair para lugares mais valorizados. Podem-se somar a esses dados as entrevistas que mostram que os idosos gostam do Pari e não têm o desejo de sair. São pessoas de nível de vida médio ou médio baixo que se acostumaram ao bairro e possuem uma ligação afetiva e de identidade com ele. É bom lembrar que o Pari é uma várzea e não possui grandes acidentes geográficos, o que facilita a mobilidade dos mais idosos, que têm o hábito de sair a pé para prover suas necessidades básicas diárias, como ir à feira, ao açougue, à farmácia, à 
padaria ou ao bazar. O bairro supre com facilidade as demandas cotidianas dessas pessoas.

Tabela 6 - Condiçăo das Pessoas Residentes - Distrito do Pari - 2000

\begin{tabular}{c|ccccc}
\multicolumn{8}{c|}{ Condição Total das Pessoas Responsáveis $/ 2000 /$ IBGE } \\
Total & Responsável & $\begin{array}{c}\text { Cônjuge / } \\
\text { Companheiro }\end{array}$ & $\begin{array}{c}\text { Filho/ } \\
\text { Enteado }\end{array}$ & $\begin{array}{c}\text { Outros } \\
\text { Parentes }\end{array}$ & $\begin{array}{c}\text { Outros Não- } \\
\text { Parentes }\end{array}$ \\
\hline 14824 & 4488 & 2528 & 5053 & 2083 & 672 \\
\hline
\end{tabular}

Fonte: IBGE/ SEMPLA/DEINFO, 2008

As pessoas residentes são, em sua quase maioria, os próprios responsáveis pela residência. A maioria residente responsável são os filhos (Tabela 6), apesar de ser grande a população de idosos no bairro. Dos responsáveis pelo domicílio, a maioria está na faixa de 30 a 39 anos (Tabela 7).

Tabela 7 - Faixa Etária dos Responsáveis - Distrito do Pari - 2000

\section{Faixa etária dos responsáveis}

\begin{tabular}{l|ccccc} 
Total & 10 a 19 & 20 a 29 & 30 a 39 & 60 a 69 & 70 e mais \\
$\mathbf{4 4 0 8}$ & 22 & 426 & 2423 & 698 & 839
\end{tabular}

Fonte: IBGE/ SEMPLA/DEINFO, 2008

\section{V - Alfabetização}

A alfabetização dos responsáveis (tabela 8) acompanha a média do município de São Paulo. O número de homens responsáveis alfabetizados por domicílio é o dobro do de mulheres. A média de alfabetização dos 
responsáveis pelos grupos familiares também não difere da média do município. Mas o nível de escolaridade é bastante baixo.

Tabela 8 - Alfabetização do Responsável por Domicílio Segundo o Sexo - Distrito do Pari -2000

\begin{tabular}{|c|cc|cc|}
\hline \multicolumn{4}{|c|}{ Alfabetização do responsável pelo domicílio segundo sexo } \\
\hline Total & \multicolumn{2}{|c|}{ Alfabetizados } & \multicolumn{2}{|c|}{ Não Alfabetizados } \\
\hline $\mathbf{4 4 0 8}$ & Homens & Mulheres & Homens & Mulheres \\
\hline
\end{tabular}

Fonte: IBGE/ SEMPLA/DEINFO, 2008

Este é o perfil demográfico dos moradores do Pari. O dado de maior destaque é a grande perda de população. Embora essa perda seja a maior entre todos os distritos, ela aparece também nos bairros vizinhos, já que, em geral, os fenômenos que atingem um determinado universo vão além dos limites físicos e se espalham pela vizinhança.

\section{2.d. A história da atividade econômica}

Na pesquisa "Região de Influência de Cidades" (Regic) realizada pelo IBGE (1993), São Paulo aparece como a grande metrópole nacional, que exerce influência em todas as regiões do Brasil, além de desenvolver sólidos laços em relações internacionais.

A reestruturação produtiva e a financeirização do capital, após a década de 1970, transformaram a organização da atividade econômica, dispersando-a espacialmente e integrando-a mundialmente, o que provocou concentração de riqueza e de controle econômico. Todas as inovações tecnológicas implantadas no país se sobrepuseram às estruturas espaciais e 
sociais já existentes. Assim, a metrópole paulistana assumiu um papel estratégico nesse processo de mundialização.

A distribuição espacial do setor produtivo formal dos empregos e desempregos no município ${ }^{1}$ mostra a predominância de serviços, com 46,3\%; em segundo lugar, o comércio, com 39,4\%; depois a indústria, com $11,9 \%$. Os estabelecimentos da indústria apresentam fortíssima concentração na área central da cidade, principalmente os do ramo têxtil.

No mapa de empregos formais no Setor Privado (2006), o distrito do Pari aparece com mais de 20.000 empregos (Tabela 9), estando entre os distritos com mais empregos formais do município. Ao desmembrar este mapa por setores, o distrito do Pari atua no setor de comércio, com 6.392 empregos, estando entre os distritos medianos do município (anexo 2); no setor de Serviços, com 5.547 empregos, destacando-se entre os distritos com menor número de empregos do município (anexo 3); no setor da indústria, com 7.260 empregos (anexo 4), entre os distritos com maior número de empregos do município; e da construção Civil, com 128 empregos (anexo 5), entre os menores do município, confirmando os baixos investimentos do setor imobiliário na área.

A atividade econômica do distrito do Pari se baseia historicamente em indústrias alimentícias, máquinas e radiadores, confecções e gráficas e no comércio de doces, balas e bolachas por atacado e varejo, utensílios domésticos de plástico e alumínio. Nos últimos vinte anos, destaca-se o grande comércio, principalmente o atacadista de roupas populares.

As informações presentes na tabela demonstram que apesar de o Pari apresentar-se com dados satisfatórios em relação aos distritos da capital, entre os centrais ele se apresenta como o de menor atividade.

\footnotetext{
1 As informações disponíveis quanto ao emprego e trabalho do presente trabalho foram elaboradas pelo Departamento de Estatística e Produção de Informações (Dirpo), da Secretaria Municipal de Planejamento da Prefeitura do Município de São Paulo (Sempla), que organiza as informações econômicas da prefeitura. Esses dados foram retirados do Banco de Dados do Ministério do Trabalho e Emprego, formado pelas autodeclarações anuais de todos os estabelecimentos empregadores legalmente constituídos (Rais - Relação Anual de Informações Sociais, no município de São Paulo, em 2004 (Sempal/Dipro, 2006).
} 
Tabela 9 - Estabelecimentos e Empregos Formais no Setor de Comércio, Serviços, Indústria de Transformação e Construção Civil, Município de Săo Paulo, Subprefeituras (centro) e Distritos Municipais (centro) - 2006

\begin{tabular}{|c|c|c|c|c|c|c|c|c|}
\hline \multirow{2}{*}{ Distrito } & \multicolumn{2}{|c|}{ Comércio } & \multicolumn{2}{|c|}{ Serviços } & \multicolumn{2}{|c|}{ Indústria de Transformação } & \multicolumn{2}{|c|}{ Construção Civil } \\
\hline & Estabc/os & Empregos & Estabc/os & Empregos & Estabc/os & Empregos & Estabc/os & Empregos \\
\hline MSP & 88.603 & 676.352 & 102.817 & 1.667 .497 & 27.353 & 526.608 & 6.908 & 161.315 \\
\hline Moóca & 6.580 & 54.868 & 5.657 & 80.673 & 4.151 & 66.047 & 216 & 6.168 \\
\hline Belém & 684 & 5.673 & 704 & 12.543 & 575 & 13.781 & 34 & 1.275 \\
\hline Brás & 1.887 & 15.478 & 668 & 6.380 & 1.593 & 18.322 & 17 & 681 \\
\hline Moóca & 1.023 & 8.598 & 1.280 & 21.946 & 521 & 12.487 & 47 & 1.338 \\
\hline Sé & 9.818 & 82.701 & 18.667 & 369.453 & 2.902 & 44.448 & 441 & 19.921 \\
\hline Bela Vista & 874 & 7.883 & 3.073 & 79.111 & 181 & 4.389 & 46 & 2.413 \\
\hline Bom Retiro & 1.260 & 8.734 & 1.010 & 15.452 & 1.383 & 18.238 & 40 & 4.658 \\
\hline Cambuci & 492 & 4.751 & 545 & 8.894 & 257 & 7.009 & 23 & 2.797 \\
\hline Consolação & 906 & 10.728 & 2.930 & 55.652 & 141 & 2.454 & 78 & 3.058 \\
\hline
\end{tabular}

Fonte: Pesquisa OD 2007 - Metrô, São Paulo.

\section{2. e. A história da ocupação urbana}

O uso do solo é um elemento muito importante para a compreensão da estruturação urbana. É a relação do tecido urbano, formado por ruas e lotes vinculados ao sistema viário e de transporte, com seus edifícios e instalações, que determina a configuração da cidade e promove o assentamento da população e das atividades urbanas. O espaço mais determinante da estrutura urbana é o centro principal, onde se realizam diversas atividades, responsáveis por um considerável número de empregos e de produtos disponíveis ao consumo da população em geral (VILLAÇA, 1998). Além dele, existem os polos regionais principais e os de menor importância. O Pari não é um polo, mas, pela proximidade com o Brás, que já foi citado como o primeiro centro secundário do município - "sub-centro 
de comércio e serviços da região metropolitana: O Brás" (idem, 1998: 118), herda atividades ou funções do bairro vizinho.

Efetuamos a pesquisa sobre o uso do solo no Pari em 2006, tendo como ponto inicial a identificação das quadras fiscais ${ }^{3}$ do distrito. Foram conferidos todos os imóveis de cada quadra, com a finalidade de distinguir cada imóvel com seus usos específicos (tabela 8). A tipologia adotada é aquela estabelecida pelo código do TPCL (Taxa Predial de Limpeza e Conservação) organizada pela Secretaria de Finanças/PMSP, que tem por objetivo a tributação referente ao IPTU (I mposto Predial e Taxas Urbanas). A TPCL contém todas as propriedades imobiliárias na área urbana no município de São Paulo, porque constituem fator gerador desses tributos a propriedades, domínio útil ou posse do bem imóvel, constituído ou não, bem como a utilização de serviços de limpeza pública e de conservação de calçamento e de leitos não pavimentados do logradouro onde o imóvel se situa. O TPCL é organizado em setores fiscais, sendo cada setor composto por quadras (mapa 12).

\footnotetext{
${ }^{3}$ As Quadras Fiscais são plantas de cada quadra do município onde está desenhado e numerado cada lote, com suas medidas, nomes das ruas e respectivo codlog (código do logradouro), número da quadra e a numeração correspondente ao setor de localização no município. As quadras fiscais são referências para a Secretaria de Finanças especificarem cada contribuinte, para o lançamento do IPTU (Imposto Territorial e Predial Urbano).
} 


Tabela 10 - Usos do solo
\begin{tabular}{|lc|}
\hline \multicolumn{2}{|c|}{ Usos do Solo } \\
\hline Residencial(1) & 4.408 \\
Comércio/Serviço/ & 1.119 \\
Atacadista(2) $^{(2)}$ & \\
Indústria e Oficinas & $(3)$ \\
Instituição(4) & 631 \\
Cortiço e Favela(5) & 79 \\
Misto & 164 \\
Vazio & 390 \\
Aluga/Vende & 53 \\
Estacionamento & 88 \\
Em construção & 60 \\
\hline
\end{tabular}

(1) $2 \mathrm{CDHU}, 3$ abrigos, 6 conjuntos habitacionais e 1 conjunto da COHAB (olarias).

(2) 2 Shoppings Centers e 71 bares.

(3)Almoxarifado do Metró e 74 oficinas.

(4)Grupo Escolar, EMEF, Fatec, Biblioteca, Portuguesa de Desportos, SPtrans, Limpurb, SUS, Semab, igrejas.

(5) 2 favelas e 162 cortiços.

Fonte: pesquisa de campo da autora (2006). Contagem manual. 
Mapa 12 - Uso do Solo - distrito do Pari - 2006

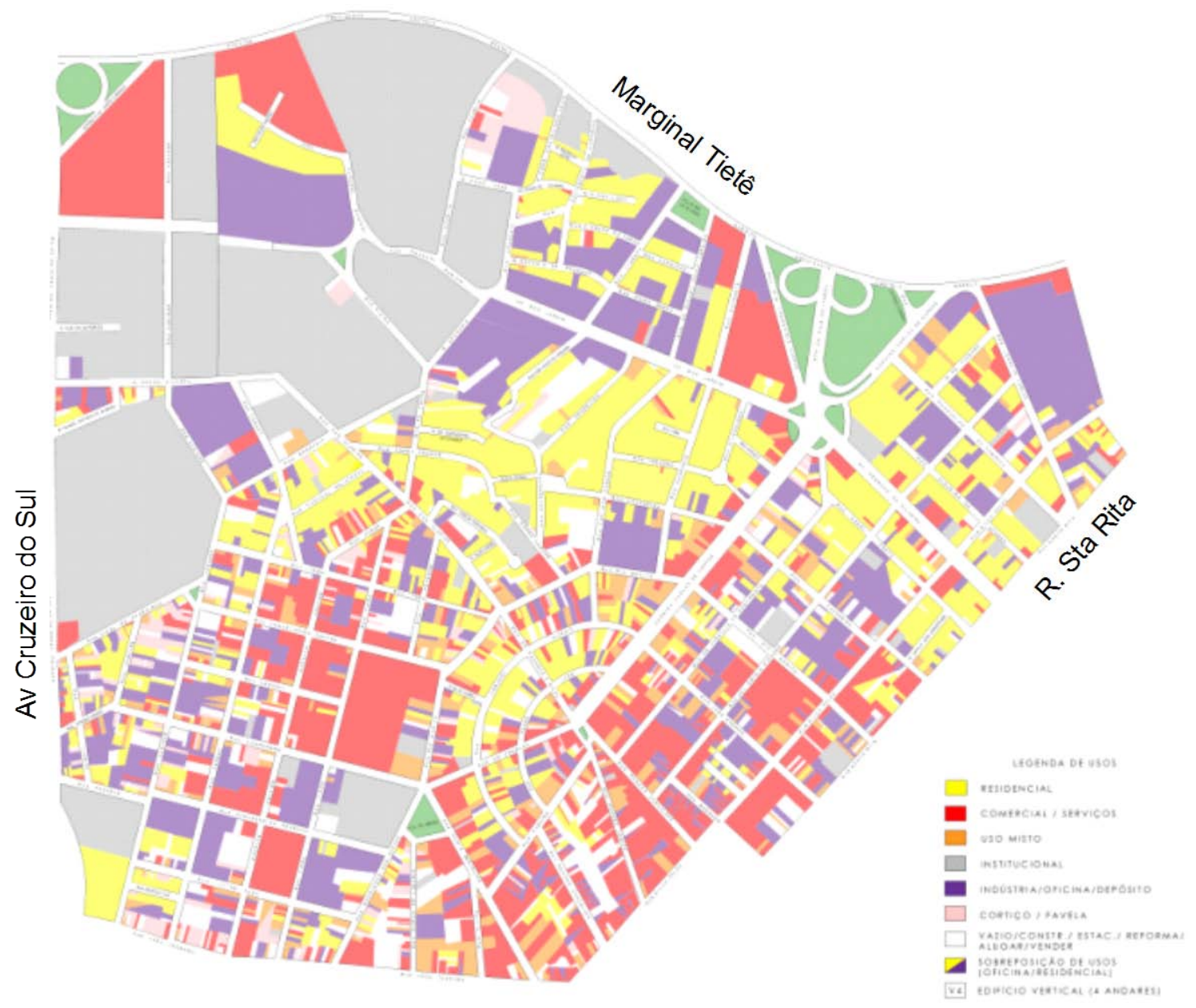

LEGENDA

Residencial

Comercial e serviço

Uso misto

Institucional

Indústria/ galpão / depósito

Cortiço/ Favela

Vazio / estacionamento / reforma/ vender ou alugar

Sobreposição de usos - indústria e residência

Edifício Vertical 
Procedemos a uma vistoria para checar os usos atuais do distrito do Pari, pois o TPCL identifica os usos que predominam em cada quadra, e não todos os realmente existentes, o que acarreta uma distorção da realidade. Além disso, o TPCL contém um fator subjetivo na distinção de alguns códigos, como o de cortiço, uma vez que pode estar associada a valores relativos às condições físicas do imóvel. Predomina a definição de uso misto, sem que se discrimine o tipo de atividade; e, para a definição, é considerada a declaração do proprietário do imóvel, sem que se realize uma vistoria. Desses dados podem ser definidos os tipos de cada código em detalhe. A evolução dos usos mostra como a ausência de detalhamento do TPCL dificulta à compreensão da leitura histórica dos usos, sendo a vistoria a única maneira de poder esclarecer esse processo.

Mapa 13 - Uso do Solo - Distrito do Pari - 1976

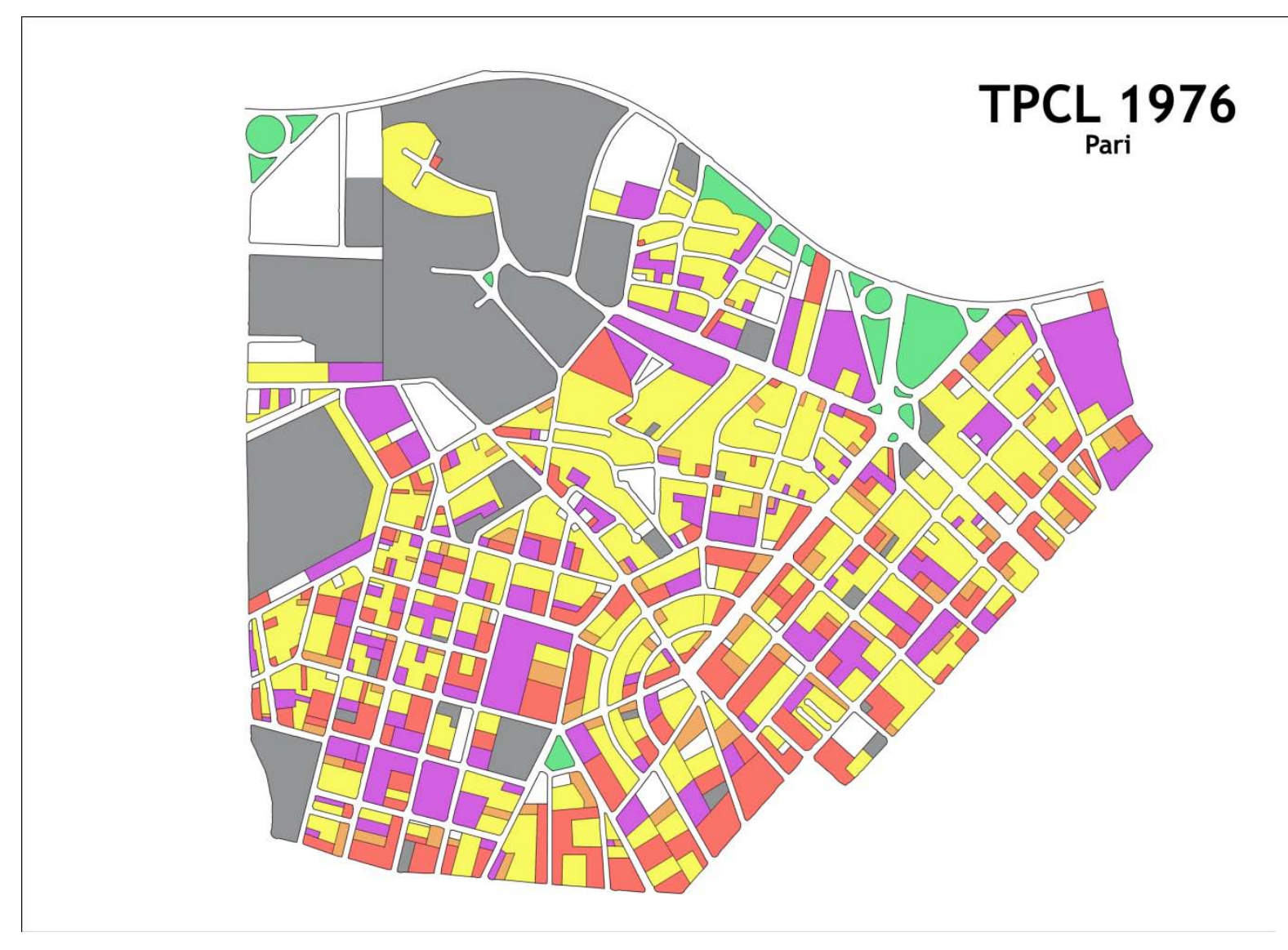

Legenda: página 85 
O mapa 13 mostra os dados do TPCL de 1976, com a predominância de usos do distrito. Podemos notar que a diversidade é muito menor do que o mapa de 2006 e que há dados equivocados, como os da quadra 104, do setor 17 (Foto 11), onde há muitos anos está instalada a fábrica de bolachas Bela Vista. Podemos observar, também, o vazio da quadra 98, do setor 18 (Mapa 14), que era de propriedade da municipalidade, antiga área devoluta da várzea do rio Tietê, constante, até hoje, no mapa de áreas públicas do GEOLOG/PMSP (Mapa 15), onde em 1980 foi instalado o Shopping D. O vazio da Rua Azurita é ocupado hoje, em uma parte, pelo Departamento de Limpeza da Prefeitura (LIMPURB/SIURB/PMSP) (Quadra 106, setor17), e em outra por cortiços e pelo famoso restaurante "Galinhada do Bahia" (Foto 12). Nota-se, também, que no uso habitação não se especifica se é vertical, horizontal ou cortiço, tudo é habitação. Porém, podese observar, principalmente, as mudanças ocorridas pelos imóveis adquiridos pelos coreanos que se tornaram igrejas e shoppings. É preciso salientar a diferença de uso da Rua Silva Telles, hoje muito mais comercial do que em 1976.

\section{Foto 11 - Fábrica de bolachas Bela Vista}
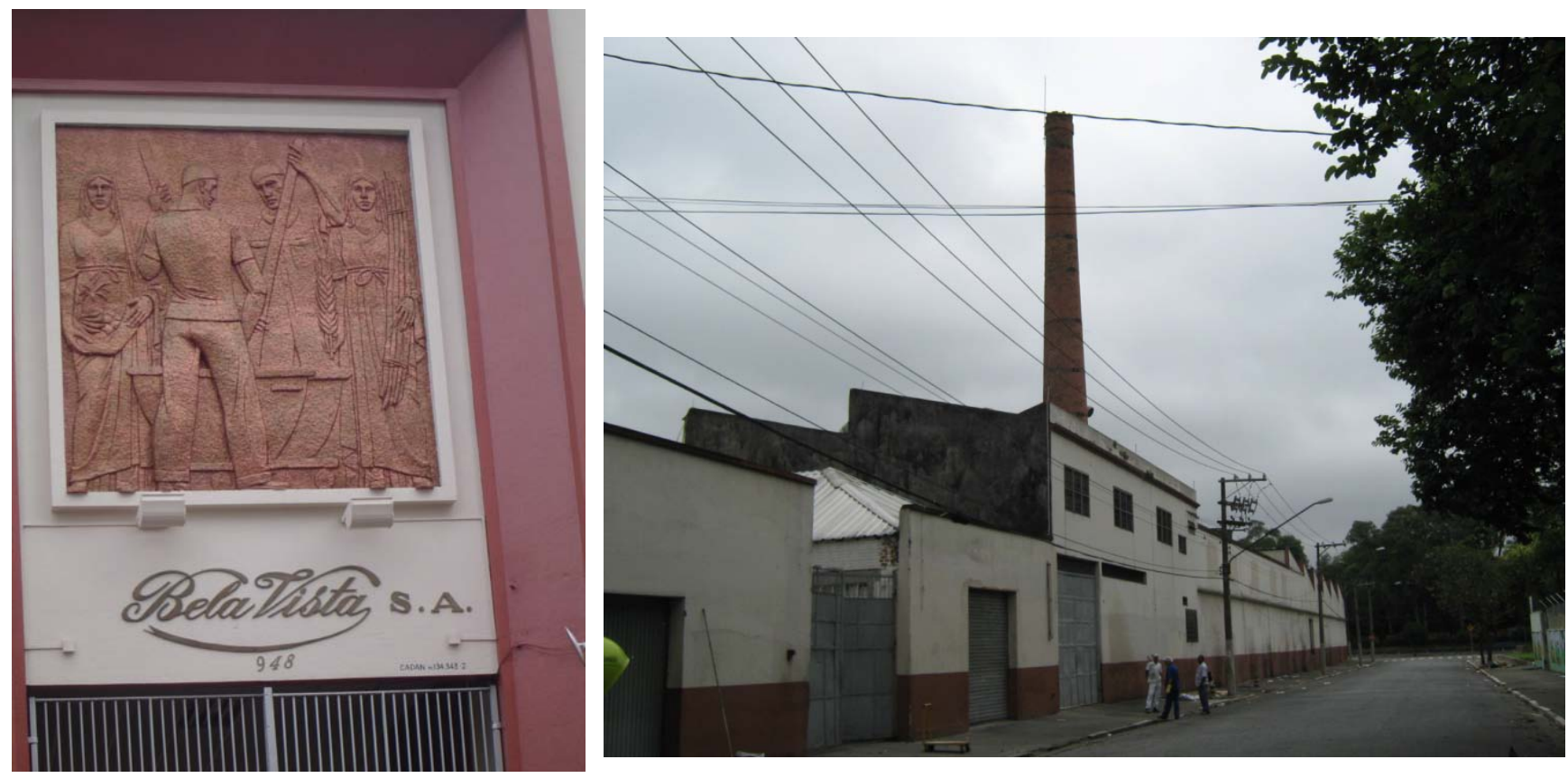
Mapa 14 - Quadras 91, 96, 98 e 99 do setor 18 e Quadra 101, 103 e 105 do setor 17
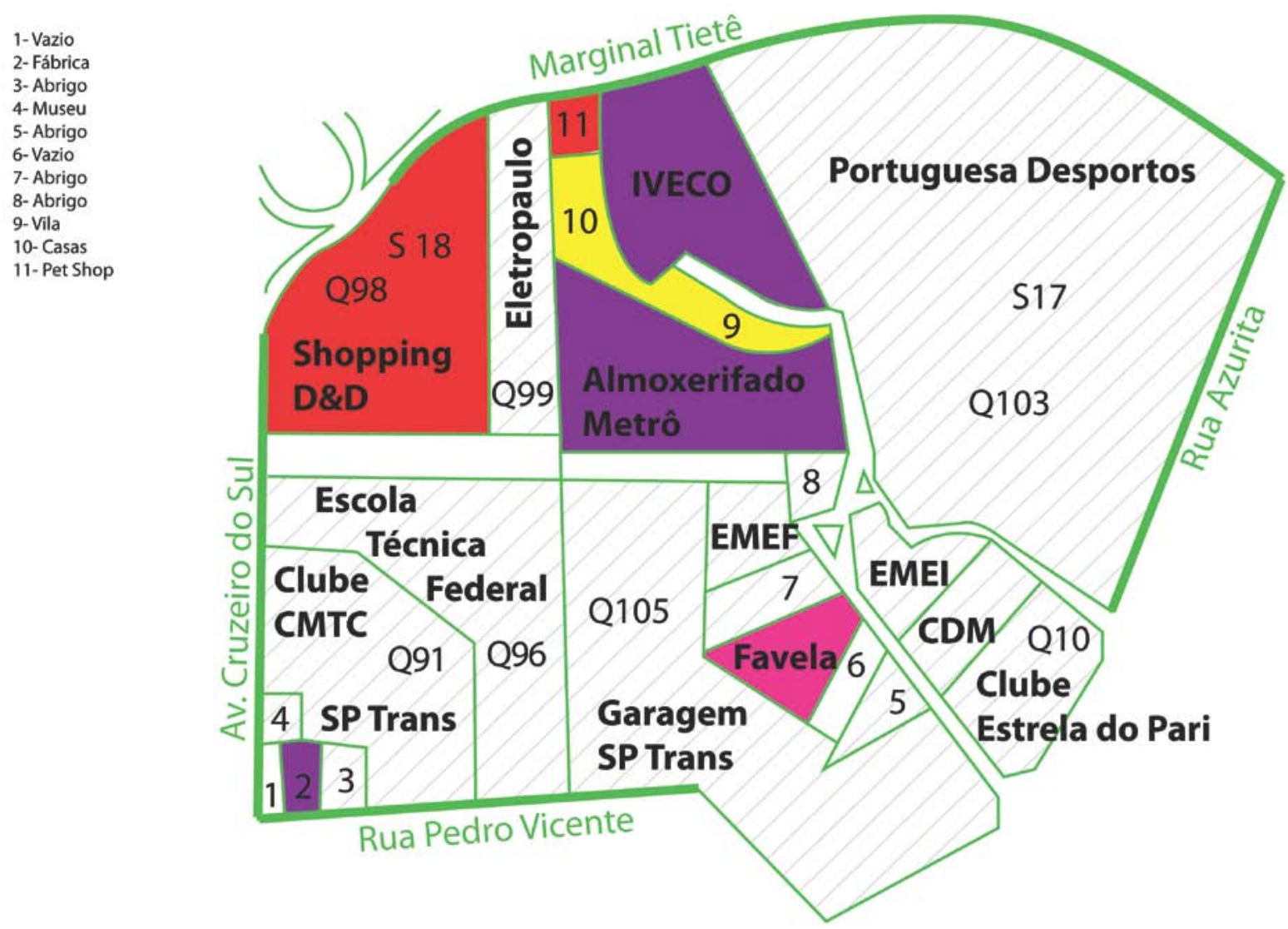

Foto 12 - Restaurante “Galinhada do Bahia”

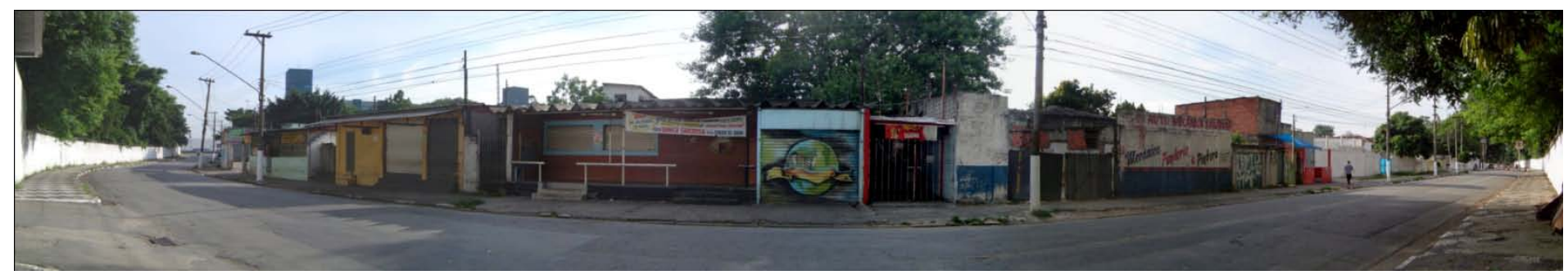


Mapa 15 - Áreas Públicas do Distrito do Pari - 2006

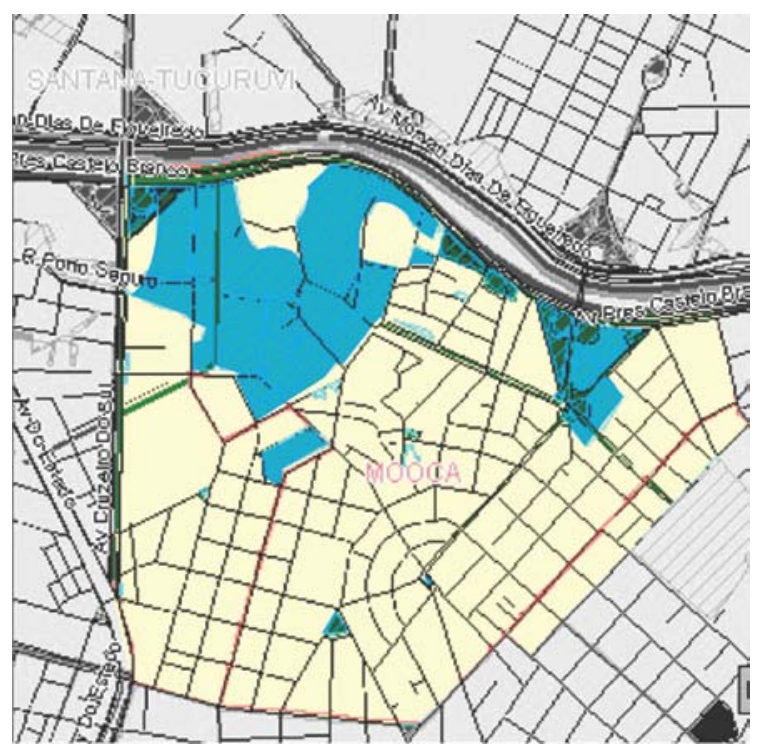

Fonte - (Geosp/ PMSP, 2006).

As quadras do Pari não são homogêneas, principalmente as localizadas no Canindé, muito irregulares e com dimensões bem grandes. As áreas próximas ao rio Tietê, por terem sido áreas devolutas, foram apropriadas de forma irregular, não obedecendo a padrões de loteamentos; por outro lado, muitas foram "doadas" a diversas instituições, tanto particulares como públicas.

Existem duas quadras atípicas quanto a seus formatos, completamente incomuns, e à apropriação possivelmente irregular, como as quadras 101 (Mapa 16) e 102 (Mapa 17), do setor 18. Já em 1952, elas eram quase totalmente ocupadas por pequenas habitações, tendo suas áreas vazias sido ocupadas, depois, por uma indústria e um depósito de materiais. Nessas quadras há vários cortiços e pequenas habitações junto a indústrias e galpões. Elas são contornadas por vias estreitas (de 8 metros de largura), exceção feita à abertura de nova avenida, em 1992 - Avenida Bom Jardim - , continuação da Avenida Pedroso da Silveira (que já existia em 1952). A formação do tecido dessas quadras resulta em uma malha difícil de ser 
percorrida e ultrapassada, trazendo aos moradores isolamento, segregação e dando pouca funcionalidade de integração entre as áreas. Essa configuração proporciona uma vivência monótona, não permitindo a interação de usos e da unidade funcional. Um bairro tem sua identificação criada pela interação de seus usos e de seus moradores e frequentadores, e sua dimensão física e limites formados por seus elementos naturais ou outros, criados pelo homem. Para atrair pessoas, precisa ter características e especialidades próprias.

\section{Mapa 16 - quadra 101, setor 17}

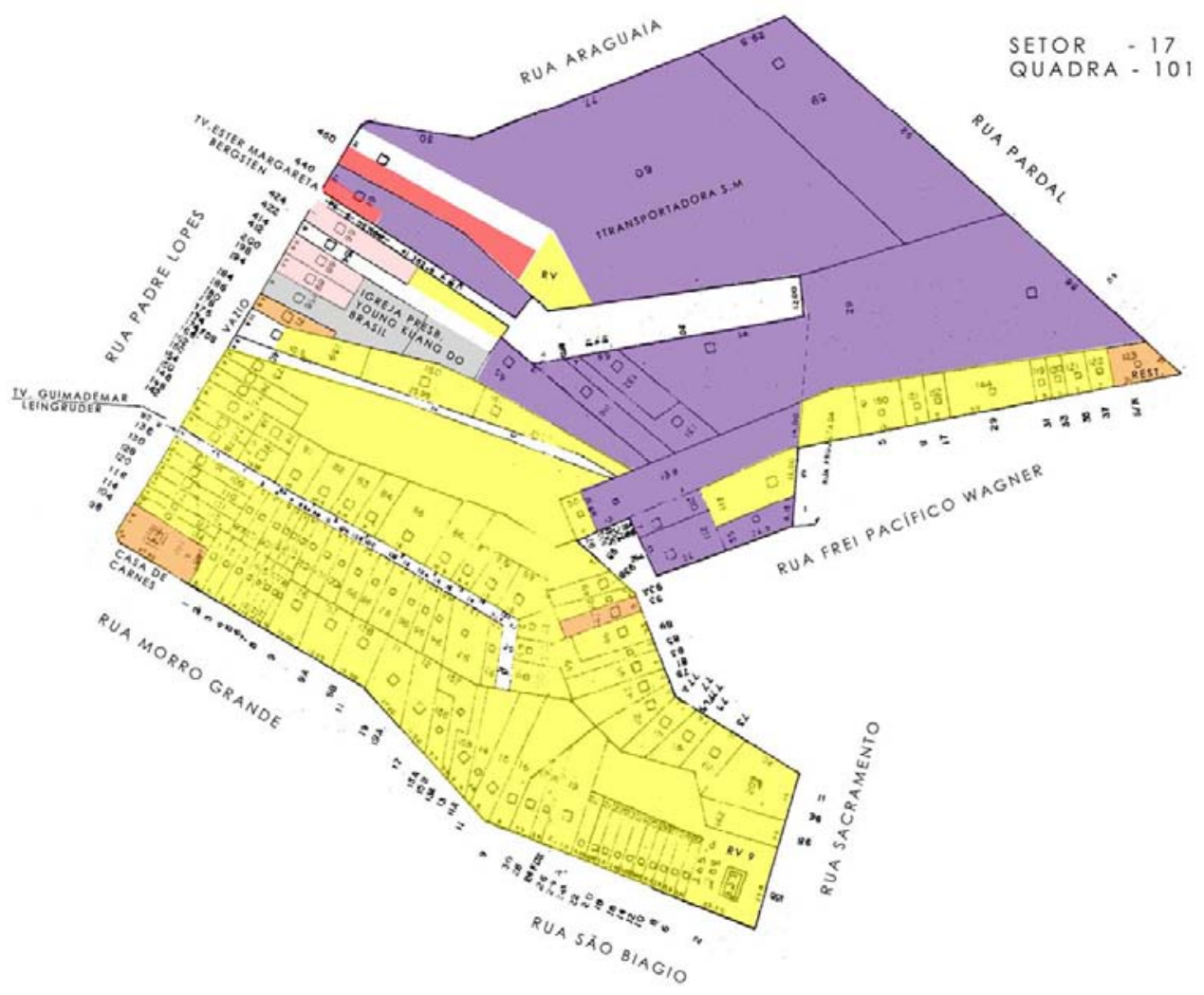

Legenda:

Residencial

Institucional

Cortiço

Misto

Comercial industrial 
Mapa 17 - quadra 102, setor 17

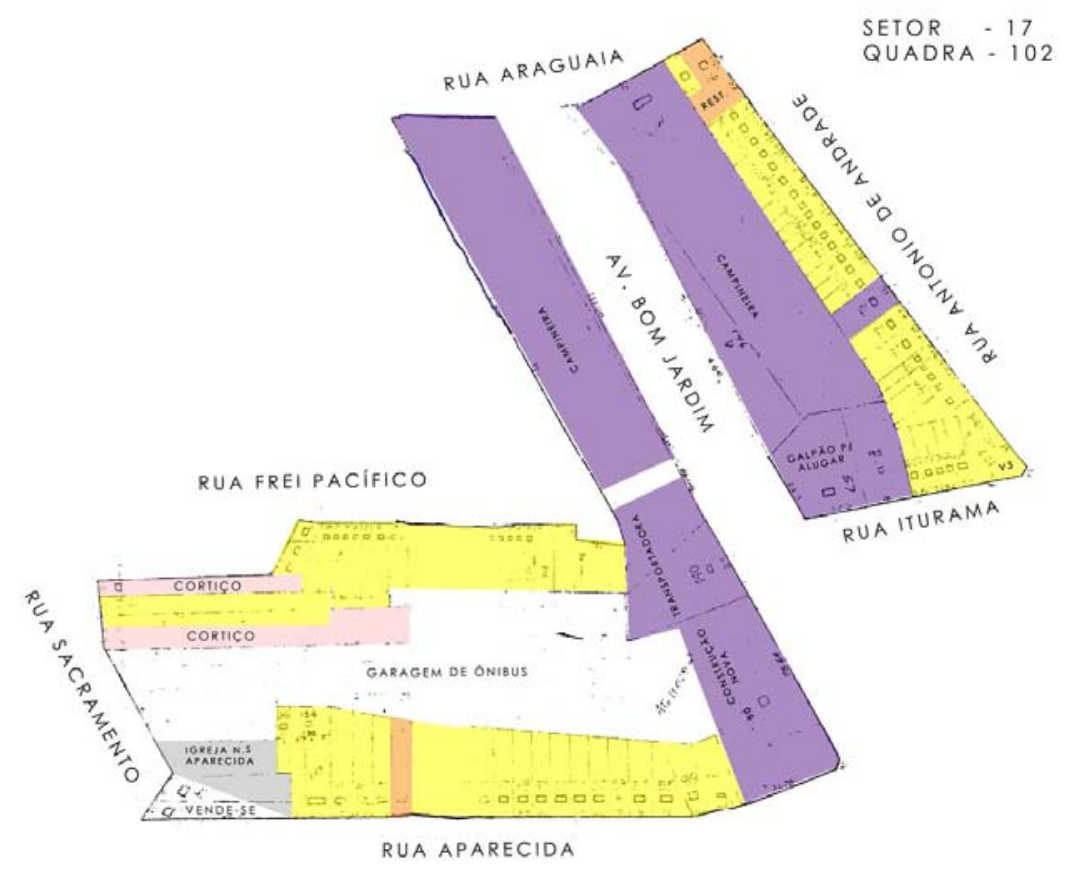

No Pari os usos são diversificados. Há 79 usos institucionais, 119 estabelecimentos comerciais, incluindo 2 shoppings e 71 bares, "botecos de esquina". É preciso ressaltar que na contagem por imóvel, conta-se um shopping por lote, assim como se conta também um bar por lote. É desproporcional, mas não há outra forma de quantificar, a não ser pelo imóvel; outra maneira seria indicar a área construída, o que só pode ser feito pelo dado do TPCL. Há, ainda: 390 imóveis com usos mistos; e 631 imóveis com indústria, galpão, depósito, almoxarifado - destes, 74 são oficinas.

Os imóveis com habitações são 2.151, sendo que há ainda 5 conjuntos da CDHU (Companhia de Desenvolvimento Habitacional e Urbano do Estado de São Paulo) e mais outro conjunto executados pela COHAB. Há 162 imóveis com cortiços (Foto 13), duas favelas e 4 abrigos. 


\section{Fotos 13 - Cortiços (Rua Canindé) e (Rua Vidal Negreiros)}
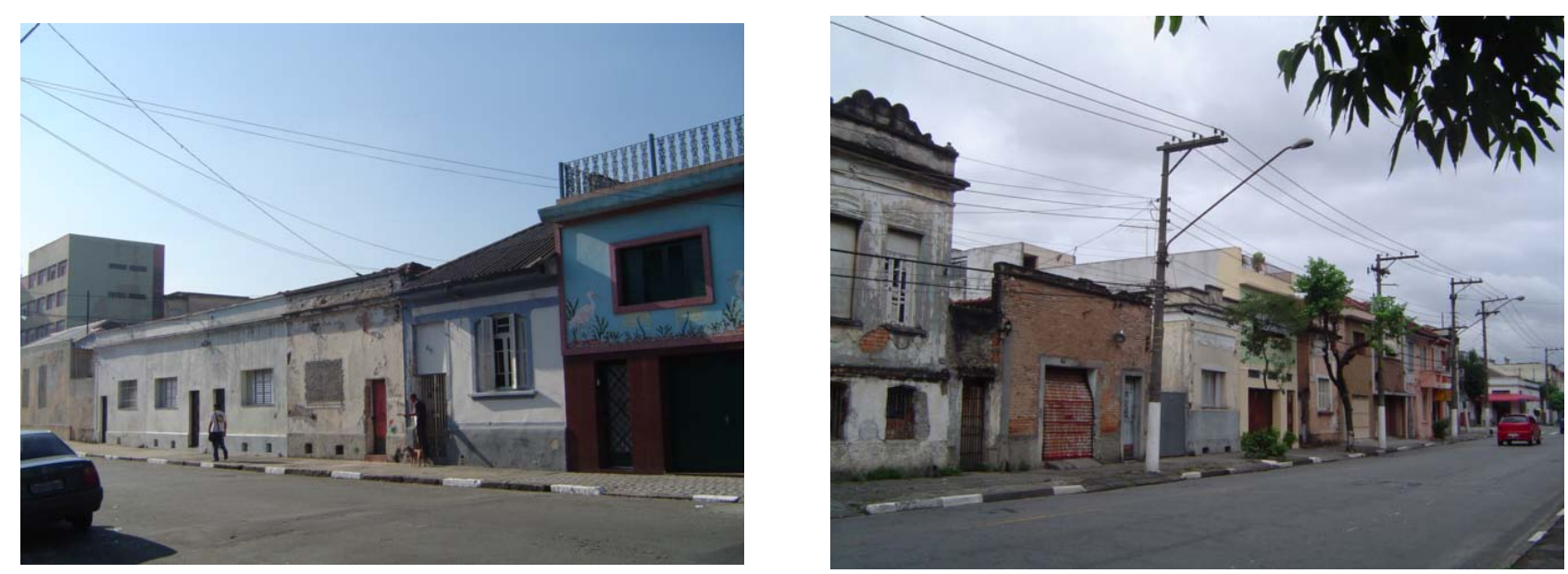

Há, ainda, 53 imóveis vazios; 88 para venda ou locação; 88 abandonados ou fechados; 60 estacionamentos; e 26 em construção, totalizando 315 imóveis praticamente sem atividade. Esse número de imóveis vazios, fechados ou abandonos, somado ainda a usos que não possuem uma ocupação efetiva e podem ser considerados como um uso para reservar o espaço para o futuro, como os estacionamentos apresentam uma situação onde o mercado imobiliário não possui interesse. É contraditória a condição do Pari, se por um lado o mercado imobiliário é fraco em comparação a bairros vizinhos, como o bairro da Casa Verde, o preço de compra e locação dos imóveis são altos dentro da mesma relação.

A Constituição de 1988 e o Estatuto da Cidade (10.247/01) estabelecem a necessidade de cumprimento da função social da propriedade urbana, o que tornaria inviável a permanência de vacância seguidamente durantes anos. Entretanto, é preciso a intervenção do Estado para declarar que um imóvel é subutilizado, e a prática no Brasil, fornece exemplos frequentes de que o patrimônio privado recebe maiores cuidados que o patrimônio público. Por essa razão é incompreensível o abandono de imóveis privados com tanta frequência nessa área. 
Foram adotadas as tipologias: residencial e não residencial, além dos terrenos vazios. Da tipologia residencial apresentam-se as seguintes categorias de uso: unifamiliar horizontal, unifamiliar vertical e multifamiliar (residência coletiva, incluindo o cortiço).

Da tipologia não residencial encontram-se: escritório, comércio, indústria, armazéns gerais e depósitos, serviços, uso coletivo (cinema, teatro, casa de diversão, clube, escola, templo) e uso especial (hotel, pensão ou hospedaria, hospital, ambulatório, casa de saúde, estação de radio, emissora de televisão ou jornal, asilo, orfanato, creche, seminário ou convento).

\section{Foto 14 - contrastes urbanos}

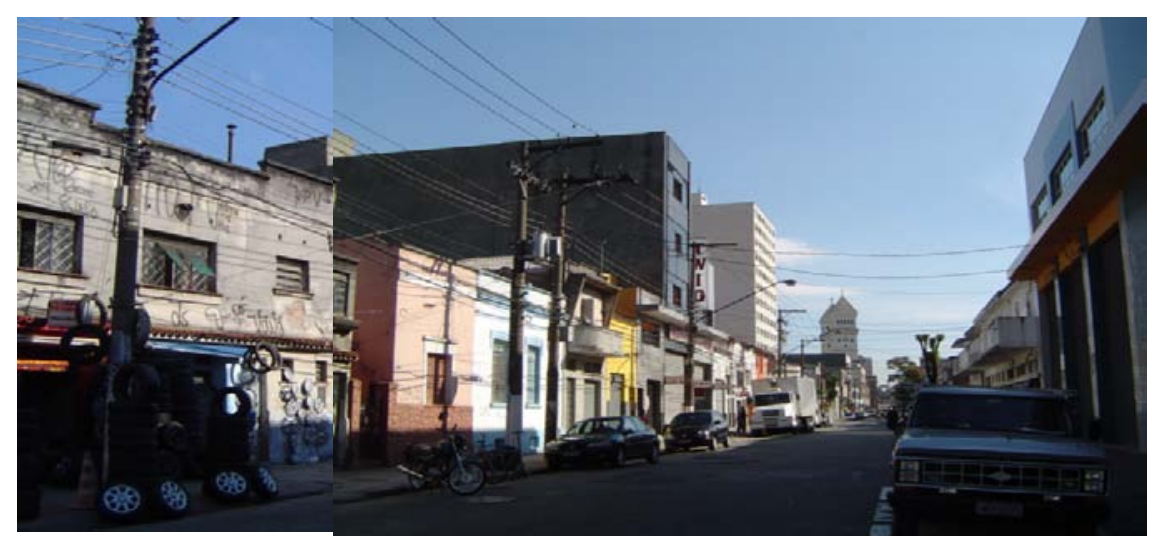

Foto 15 - I móvel abandonado - Fábrica de Leite União

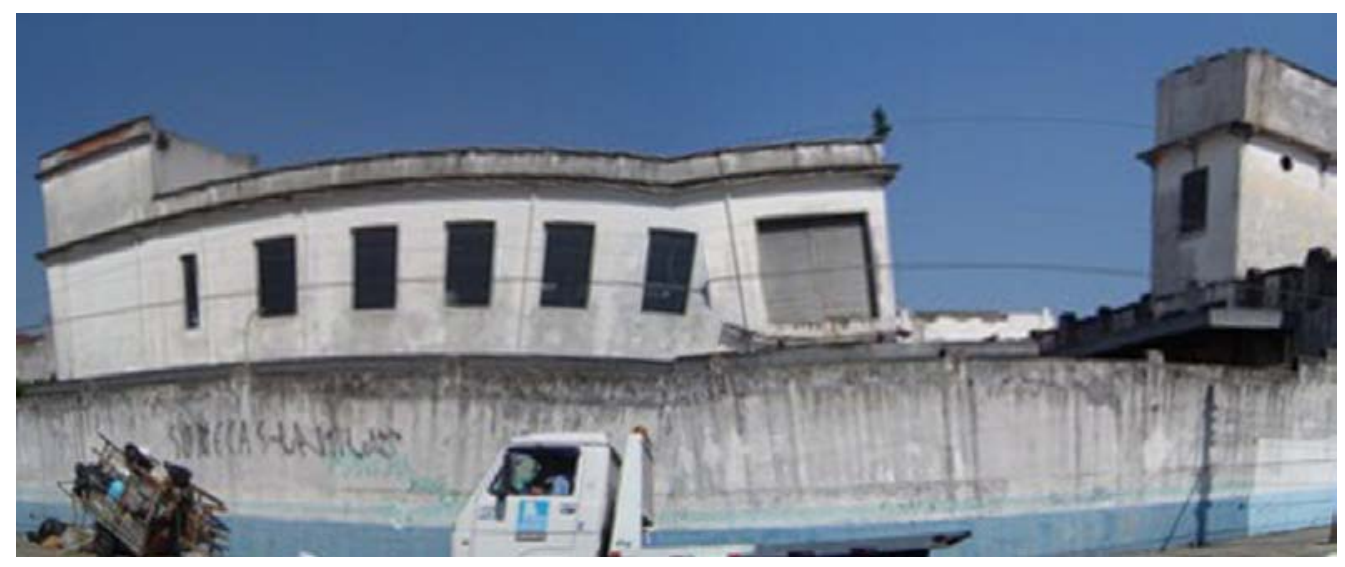




\section{Residencial}

As unidades habitacionais no Pari foram construídas, na maioria, por agentes privados que as vendiam diretamente ao consumidor. São casas simples e modestas, com poucas exceções. A ocorrência da tipologia residencial é basicamente horizontal e de baixo padrão. A presença de residência de classe média é relativamente escassa e a área é pouco verticalizada. Dos 4.408 domicílios, $68 \%$ são residências até dois pavimentos e $32 \%$ são apartamentos.

Tabela 11 - Domicílios por Tipo - Distrito do Pari - 2000

\begin{tabular}{|c|ccc|}
\hline \multicolumn{4}{c|}{ Domicílios por Tipo } \\
\hline Total & Casa & Apartamento & Coletivo \\
\hline $\mathbf{4 . 4 0 8}$ & 3.003 & 1.270 & 135 \\
\hline
\end{tabular}

Fonte: IBGE - Censo 2000

A produção de habitação popular promovida pelo Poder Público teve início a partir de 2000 pela Cohab/Sehab, para atender a Associação de Catadores de Papel, na Rua das Olarias com Rua Araguaia. O projeto arquitetônico do edifício foi bem resolvido e com apresentação diferente da maioria dos edifícios residenciais executados pelo Poder Público. O edifício fazia parte do Programa de Aluguel Social, instituído naquela gestão, o qual determina que os moradores paguem um aluguel de até R\$150,00 por mês, de acordo com a renda de cada um. Com o passar dos anos, as condições desse edifício atingiram um estado tão precário que até os cabos dos elevadores foram roubados, dificultando sensivelmente a locomoção dos moradores (Foto 16).

Foto 16 - Edifício Olarias
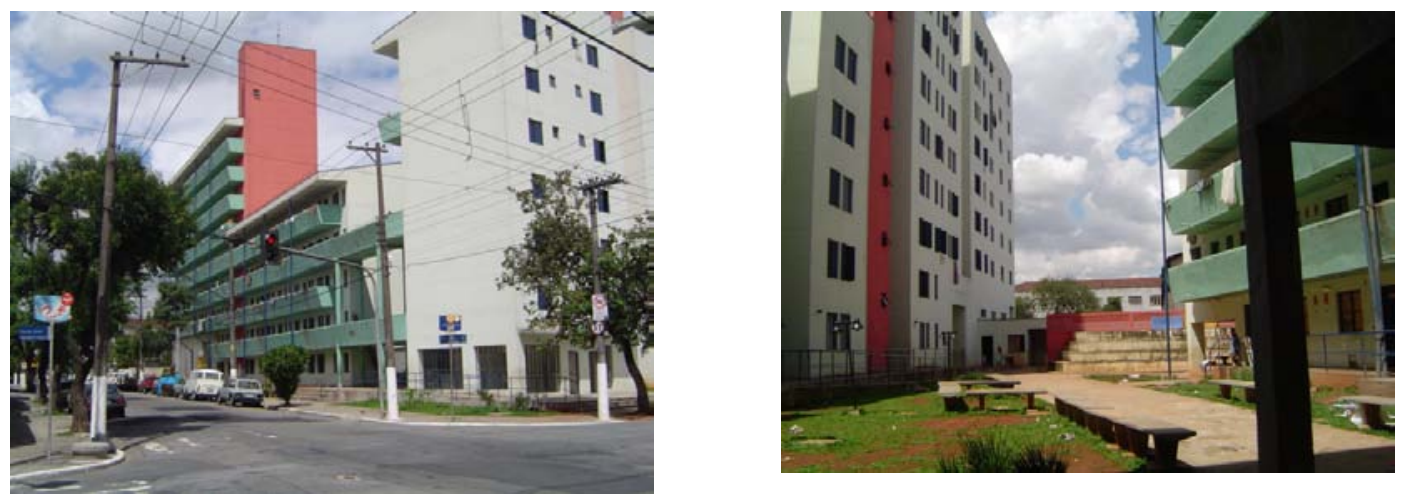
Além do Poder Municipal, há produção mais recente, da CDHU, que compreende cinco empreendimentos: o Pari A1, na Rua Canindé, 131, com 160 unidades habitacionais, entregues em 2002; Pari D, na Rua Canindé, 314, com 42 unidades habitacionais, entregues em 2008; Pari G, na Rua Canindé, 503/509, com 26 unidades habitacionais, entregues em 2008; Pari F, Rua Hannemann, 156, com 17 unidades habitacionais, entregues em 2008; e Pari A2, com 160 unidades habitacionais, sem previsão de data de comercialização (CDHU) (Foto 17).

Foto 17 - CDHU - Pari F, Rua Hanneman, 156, e Pari D, Rua

\section{Canindé, 306}
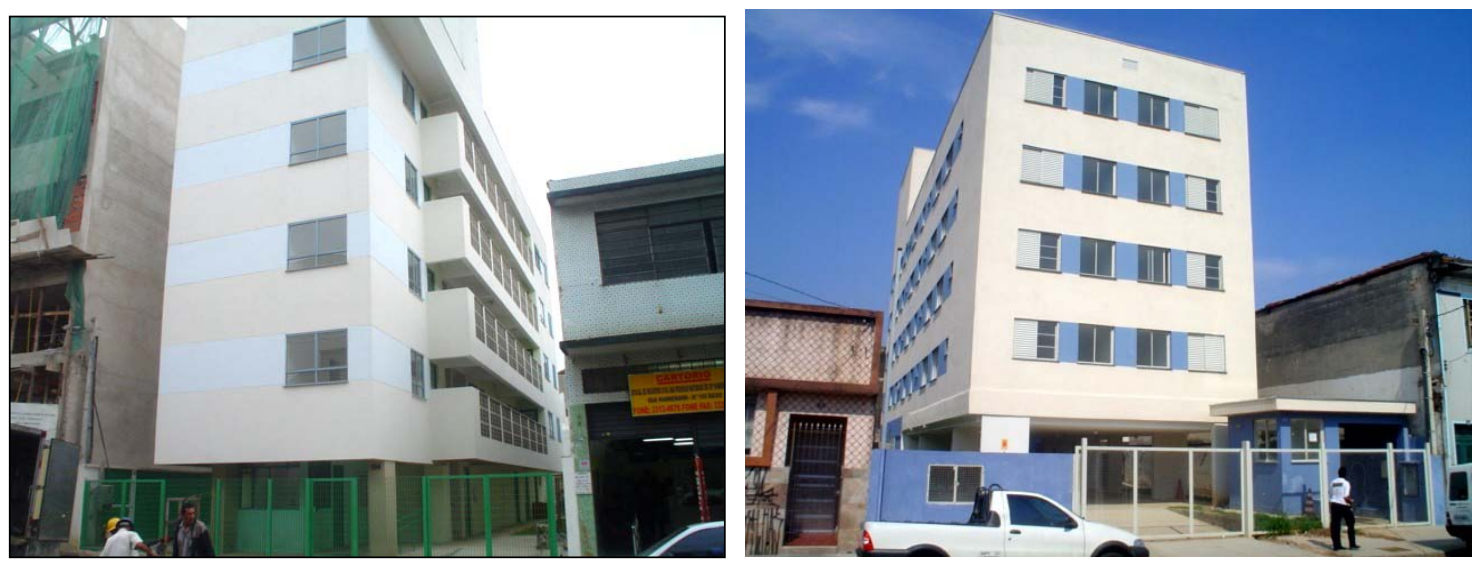

Fonte: CDHU, 2008

A tipologia residencial é encontrada por todo o distrito, mas cabe destacar todos os imóveis que se caracterizem dentro do conceito de cortiço, já que, aparentemente, muitos cortiços passam despercebidos pelos passantes da rua e pelos censos e pesquisas conhecidas (IBGE e FIPE), o distrito do Pari é um dos distritos do município com mais incidência de cortiço. 


\section{Foto 18 - habitações de mais alto padrão}
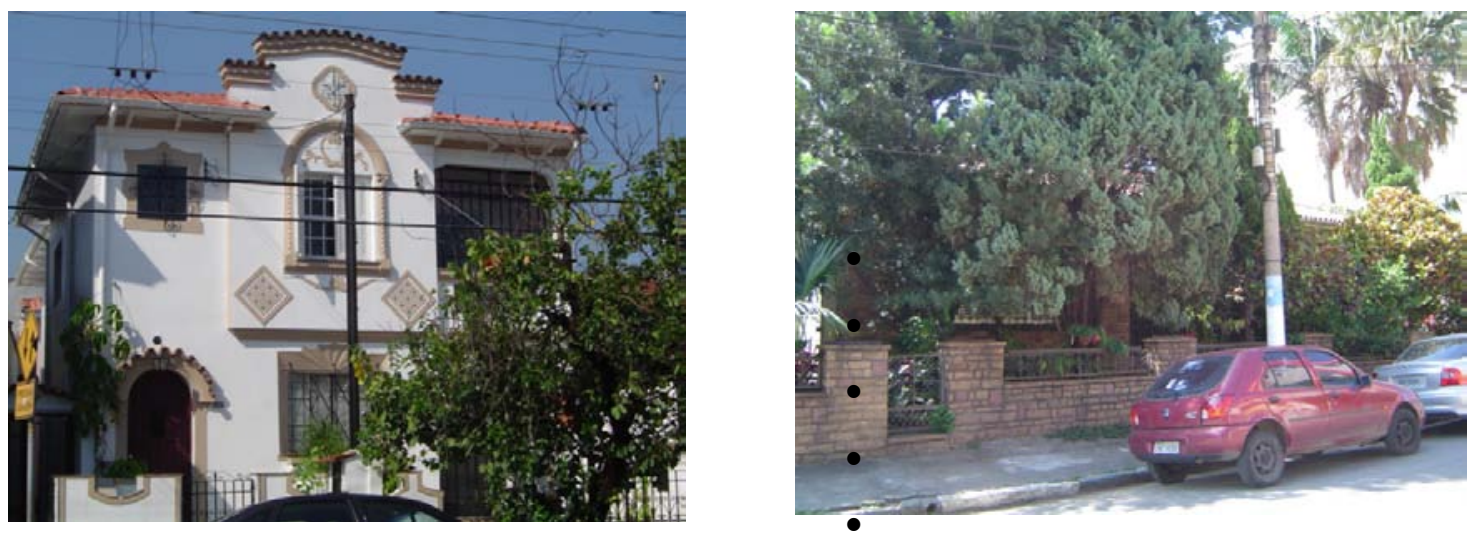

- $\quad$ Cortiço

Neste trabalho conceituamos cortiço como o imóvel originalmente unifamiliar ou multifamiliar, subdividido em cômodos, adaptados para alojamento coletivo de diversas famílias ou pessoas não pertencentes à mesma família, obrigatoriamente, com banheiros, áreas de serviços e, em alguns casos, cozinhas comuns. Em geral, as condições de habitabilidade são precárias e seus ocupantes pagam aluguel por cômodo ou vaga. O proprietário do imóvel, na maior parte das vezes, se utiliza de um intermediário, responsável pela cobrança do aluguel.

Nas pesquisas sobre cortiço há bastante controvérsia quanto ao número destes na cidade de São Paulo. A pesquisa da socióloga Suzana Tachner, de 1995, mostra uma porcentagem de $25 \%$ da população, ou seja, 2.500.000 moradores de cortiços, superando o número dos que vivem em favelas, que é de 1.000.000. A pesquisa da FIPE de 1996/97 diz que a porcentagem é de $6 \%$. A diferença entre uma pesquisa e outra é muito grande. A dificuldade para definir a existência de um cortiço, também, pois a aparência dessas habitações pode muitas vezes mostrar-se enganosa. Por outro lado, a pesquisa da Fipe foi feita por amostragem, podendo portanto ser bastante desvirtuada. Como a pesquisa do presente trabalho foi feita em campo, por 4 meses, de forma censitária, ou seja, conferindo casa por casa, acreditamos que os dados checados in loco sejam mais confiáveis. Acrescentamos, ainda, que as moradias originalmente construídas com a finalidade de serem cortiços são numerosas na área. 
O processo de deterioração que ocorre invariavelmente nos centros das grandes cidades brasileiras é fruto do abandono do Poder Público conjugado ao desinteresse do mercado imobiliário. O Estado não consegue ofertar HIS (Habitação de Interesse Social) para suprir a demanda. Por outro lado, as opções existentes, como um espaço em uma favela ou um pequeno lote na periferia, exigem a construção ou a compra do barraco. Todas essas opções requerem uma capacidade financeira para sua aquisição. Portanto, o cortiço é a saída que se apresenta às pessoas mais carentes financeiramente ou com indisponibilidade financeira imediata. Dois pontos principais são levantados: quem são esses moradores, como vivem e quais as suas condições de habitabilidade?

O problema dos moradores encortiçados está justamente na sua falta de condição financeira e na ausência de relações sociais efetivas. São pessoas, em geral, não especializadas profissionalmente e que recebem baixíssimos salários. A despersonalização e a solidão da metrópole possibilitam assim, cruelmente, que um proprietário explore várias pessoas sem condições de contratar um aluguel formal. Estudos mostram que o cortiço proporciona um rendimento muito maior que um aluguel formal, já que, nessas habitações coletivas, se cobra por cômodo ocupado, o que confere ao proprietário um rendimento muito vantajoso, face ao estado físico desses imóveis. Como a existência de cortiços obedece à finalidade precípua de máxima exploração, não há interesse de seus proprietários em mantê-los em condições adequadas, assim como os locatários não exigem melhorias. È uma troca entre necessidade e exploração que dá à cidade uma aparência de decadência e aos encortiçados um beco em saída.

As condições de habitabilidade dessas moradias são extremamente deterioradas, pois não há a menor preocupação dos proprietários com a manutenção, segurança ou salubridade. Com o objetivo de gerar o maior número possível de cômodos, eles os subdividem usando materiais sucateados, como tapumes, papelão e panos, impedindo a privacidade entre os moradores. As subdivisões são tantas que impedem o mínimo de ventilação e insolação. Os banheiros são sempre minúsculos, insalubres, mal cuidados, insuficientes e quase sempre com pouca ventilação. As instalações elétricas e hidráulicas são resolvidas com adaptações improvisadas e 
perigosas. Infiltrações e vazamentos são constantes. As roupas lavadas são penduradas em corredores internos, com os fios elétricos muitas vezes fazendo o papel de varais.

O tempo de permanência do morador no imóvel varia muito. Assim com há os recém-chegados a São Paulo, que não sabem quanto tempo ficarão e demonstram a intenção de sair rapidamente, há os que estão no mesmo cortiço há mais de 10 anos, chegando alguns a 30 anos.

A procedência da quase totalidade dos moradores de cortiços do distrito é o nordeste do país, a Bolívia e o Paraguai. A maioria exerce alguma atividade que Ihes garanta algum ganho, em geral um subemprego, muito comumente em oficinas de costura, sem registro legal, como os bolivianos que trabalham nas confecções de coreanos, bolivianos e brasileiros instalados ao redor da Rua Silva Telles. As atividades mais frequentes, além da costura, são: venda ambulante de milho, frutas ou outras mercadorias e, no caso das mulheres, o trabalho doméstico ou de faxina em escritórios. Grande parte não possui registro em carteira ou qualquer vínculo empregatício que Ihes assegure estabilidade ou tranquilidade para uma melhor qualidade de vida. No entanto, é comum o acesso a bens de consumo do cotidiano, como geladeira, fogão, TV, vídeo e aparelho de som.

Em conclusão, os moradores dessas habitações subnormais não são excluídos do mercado imobiliário e sim vítimas de um mercado informal perverso, no qual a forma como o dinheiro circula mostra a solidão do indivíduo. Ele é apenas um irrisório consumidor. 


\section{Foto 19 - cortiços}
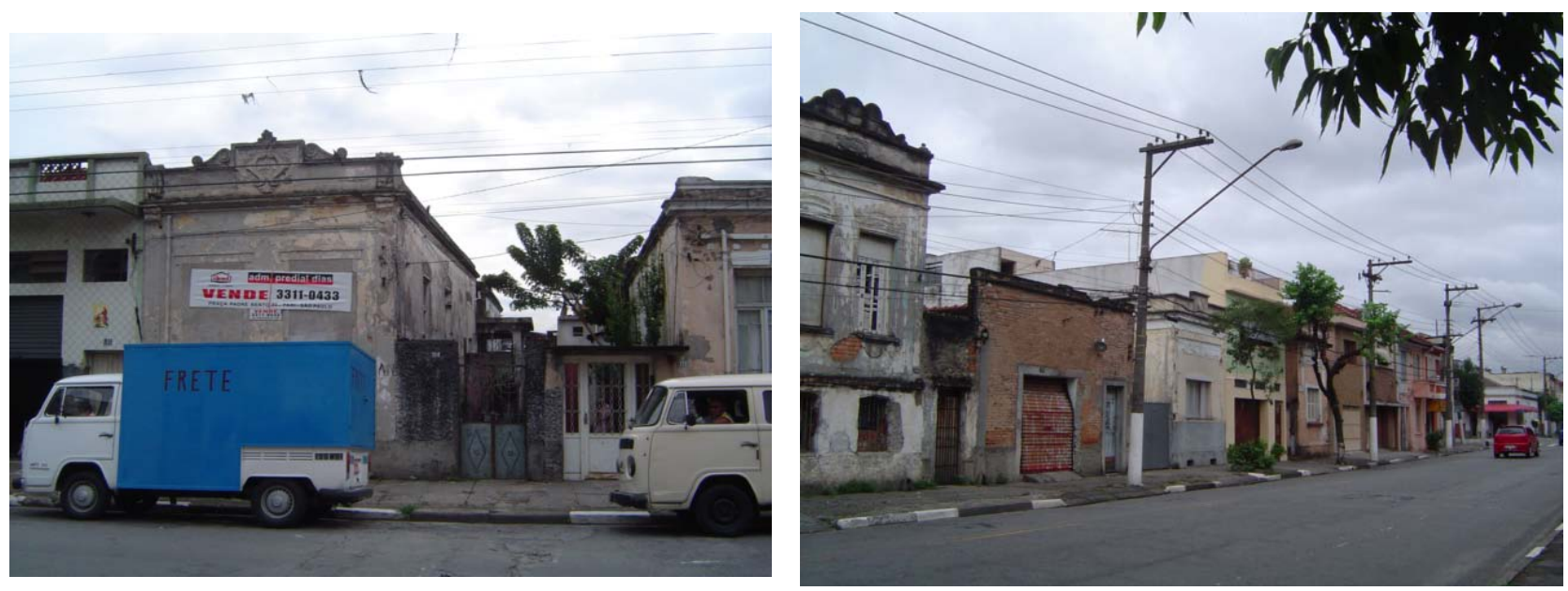

No Pari o número de cortiços encontrados foi de 162 e duas favelas. (lotes em cor rosa Mapa 12) O número de residências é de 4.408 (vertical ou horizontal) (idem). No entanto, é relevante o número de imóveis vazios e para vender ou alugar: 141. É quase a mesma quantidade de cortiços. É importante frisar que a porcentagem de imóveis alugados é de 49\%, para uma porcentagem no município de 21,6\% (Censo 2000, IBGE).

O número de cortiços é um dos maiores entre os distritos da cidade a pesquisa do IBGE (2000) contou 135 cortiços para 4.408 domicílios, ou seja, 3\%. Não é o bairro com mais cortiços: no Brás há 1.024 (12,5\%); no Bom Retiro, 876 (10,6\%); na Sé, 592 (7,7\%); na Liberdade, 974 (4,4\%). Em nossa pesquisa, realizada em 2006, foram identificados $162^{4}(3,6 \%)$ cortiços no distrito do Pari.

4 A diferença entre os números pode decorrer de como se conceitua o cortiço, e se a pesquisa é feita por amostragem, ou por contagem. 
- Favela

Em 1945 o Pari recebeu 904 pessoas que se instalaram numa área de $34.500 \mathrm{~m}^{2}$ situada na antiga várzea do rio Tietê e lá constituíram uma favela com 168 barracos que abrigavam 230 famílias (Foto 2 e 3, - 1940 - sem favela/ 1952 - com favela). Essa favela perdurou até 1960, quando 60\% desses moradores adquiriram casas próprias no bairro.

Hoje, há duas favelas no distrito que convivem com a população, não sendo explícita, entre os entrevistados, uma atitude de intolerância por elas estarem ali implantadas. Parece que, desde que a presença da favela não interfira diretamente no mercado de imóveis, nem na vida dos moradores, a convivência é aceita. E elas estão suficientemente escondidas para não desagradar os moradores ou compradores e locatários de imóveis.

\section{Foto 20 - Favela do bairro}

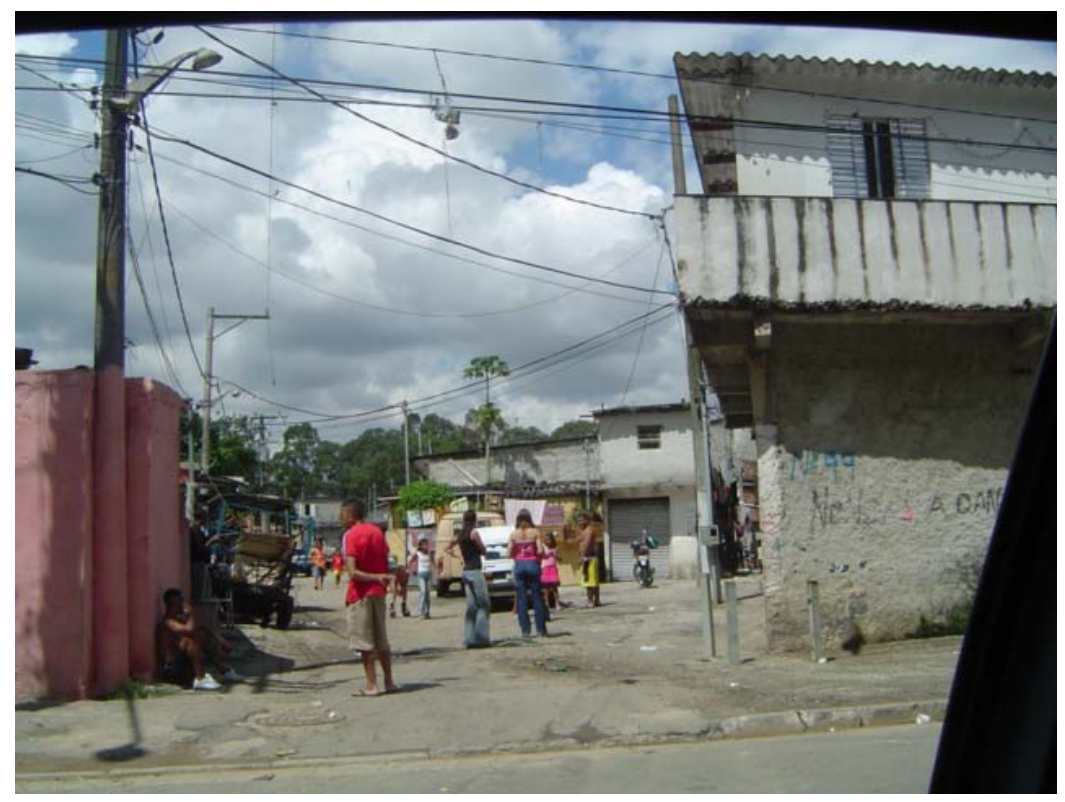

\section{I. Não Residencial}

A existência de um centro de comércio e serviço resulta da necessidade por essas atividades, que se localizam em local de maior acessibilidade. O Pari não dispõe de um eficiente serviço de transporte de 
massa, mas possui fácil acessibilidade por meio do transporte individual, o que facilita a mobilidade da população e faz do bairro um núcleo de comércio e de serviços.

Os primeiros usos não residenciais da região coincidem com o início da urbanização paulistana. Já em 1849, foi implantada a alfândega seca no Pátio do Pari, que, apesar de não pertencer ao distrito do Pari, mas ao distrito do Brás, assim como um conjunto de depósitos da São Paulo Railway, proporcionou o surgimento da atividade do comércio de exportação e importação, dando expansão e diversidade aos usos existentes e impulsionando a urbanização do distrito (AMADIO, 2004). Soma-se a isso o fato de que a primeira fábrica em São Paulo foi instalada no Brás, a uma quadra do atual distrito do Pari.

Até 1970, o comércio do Pari e algumas atividades de serviços prosperavam. A partir de 1973, o ritmo do comércio foi diminuindo e o aumento da população teve um decréscimo acentuado. Mesmo na área mais comercial, como nas ruas Barão de Ladário, Maria Marcolina e Muller, até 1970, ainda restavam algumas casas antigas, baixas e humildes, moradias de operários que foram transformadas em lojas ou até mesmo em indústrias de vestuário. E foi só com a chegada massiva de coreanos, em 1980, que o bairro tendeu a se recuperar.

O distrito do Pari é um local de aglutinação de atividades terciárias e secundárias que servem a distintas áreas de influência. O total de imóveis com atividade de comércio, de serviço ou atacadista (em vermelho no mapa 11 , pág.) e de indústria e oficinas (em roxo) é de 1.750 imóveis.

\section{- Industrial}

São Paulo foi um polo importante desde o início da industrialização brasileira, que se aprofundou na década de 1930. As fábricas da cidade, na sua instalação, privilegiaram a proximidade ao eixo ferroviário da Estrada de Ferro São Paulo Railway (Santos-Jundiaí e RFFSA), na região do Brás, Belenzinho, Pari e Moóca, e à margem do rio Tietê, na região da Barra Funda, ao longo da Estrada de Ferro Sorocabana.

Em relação à ocupação industrial, o Pari foi um prolongamento do Brás. As principais indústrias que se instalaram no bairro: alimentares, de 
confecções e gráficas, máquinas e radiadores. As indústrias alimentares, que hoje são poucas em relação a um passado recente, produziam principalmente biscoitos, balas, chocolates e doces. Entre elas encontravamse algumas das maiores do Brasil, como Tostines, Confiança, Bandeirantes, Neusa, Bravanus e Dizioli. Ficava lá também a antiga fábrica de panelas Panex (Foto 21).

Nas décadas de 1960 e 1970 diversas indústrias alimentícias e locais de revenda desses produtos se instalaram no distrito, e a partir de então o Pari tornou-se conhecido como o "bairro doce". Já na década de 1980 essas mesmas fábricas e comércios entraram em decadência, sendo substituídos pela atividade comercial de utilidades domésticas de baixo custo, que se tornou uma especialização do local (AMADIO, 2004:361).

No ramo da indústria do vestuário, as maiores confecções são as de coreanos, mas há também as de brasileiros e até de bolivianos, com a produção de roupas populares, nas quais são utilizadas fibras sintéticas (náilon, helanca e poliéster e alguns tecidos novos importados da Coreia). A indústria de confecção no Pari é mais popular, por exemplo, que as do distrito do Bom Retiro, que exportam moda para o resto do país e abastecem os shoppings do Brasil inteiro.

\section{Foto 21 - Metalúrgica e antiga Fábrica Panex, Rua Tiers}
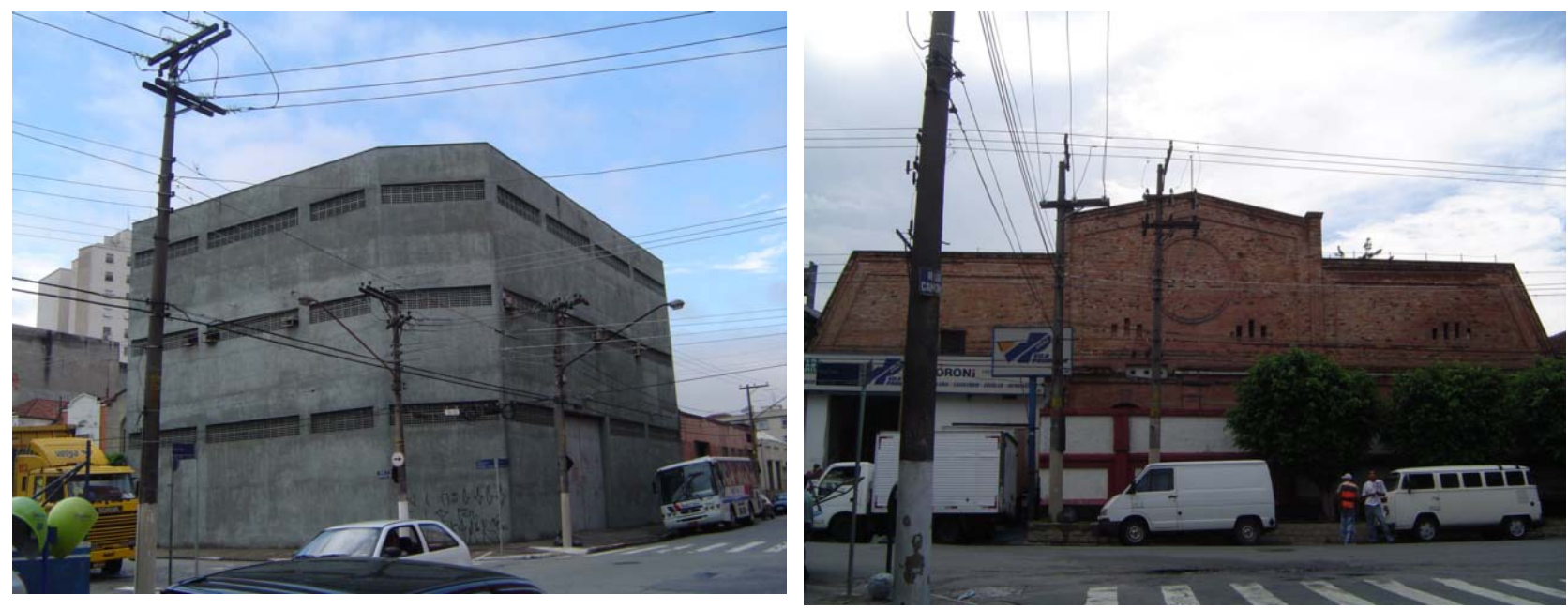
Hoje são poucas as indústrias que continuam no Pari; as que se destacam são as de confecções que não precisam de grandes áreas para se instalar e são permitidas praticamente em todas as zonas de uso do município, pois se enquadram na categoria de uso nR1 - não residencial / Grupo de atividades: Serviços Técnicos de Confecção ou manutenção, a categoria permitida em qualquer zona de uso.

As oficinas automotivas, que, por estarem instaladas em galpões, também são consideradas, dentro do TPCL, como indústrias, foram computadas na mesma tipologia. Para o decreto de uso $n^{\circ} 45.817 / 05$, elas são classificadas como nR2 / Grupo de atividades: Oficinas, e sua permissão é mais restrita entre as zonas de uso. Considera-se que esse uso é mais incômodo que o das confecções - estas geram tão pouco incômodo que mesmo para caracterizar um imóvel dentro desse uso, é muito difícil, pois elas podem, muitas vezes, passar por simples habitação. O reconhecimento é efetuado, apenas, quando há uma sinalização clara ou se, por acaso, se verificar o interior do imóvel e constatar o funcionamento da confecção.

Computamos também como indústrias grandes galpões que podem servir para armazenar materiais, independentemente de seu tamanho e sua utilização.

Assim, dentro desse contexto registramos 631 indústrias, das quais 74 são oficinas mecânicas e um (1) almoxarifado do Metrô.

- Comercial

O miolo comercial do bairro - ruas Silva Telles, Maria Marcolina, Bresser e João Teodoro (Mapa 18) - pode oferecer os preços mais excepcionais, especializado que é em venda de vestuário e acessórios de padrão popular. A agitação do Pari gira em torno da Rua Silva Telles (Foto 22), que atravessa o bairro na extremidade leste, se estendendo desde a Marginal Tietê ate a Praça República da Koreia, esquina com a Rua João Teodoro (sentido norte-sul), cruzando com as outras ruas comerciais citadas acima. A influência dessa via é ímpar e o seu movimento é um confronto com a quietude do resto do distrito. Não se pode tomar essa parte do bairro 
como o todo. Contudo, é possível até considerar essa via como uma referência eficaz para o reconhecimento do bairro como um centro comercial.

No comércio, além da especialidade em roupas, o Pari tem uma função atacadista essencial na cidade, de distribuição de materiais plásticos em geral, brinquedos, eletrodomésticos, materiais escolares e materiais utilizados em cozinhas domésticas, tanto de plástico como de alumínio. Os atacadistas se situam nas ruas Vautier, Tiers e transversais.

\section{Mapa 18 - Centro comercial do distrito do Pari}

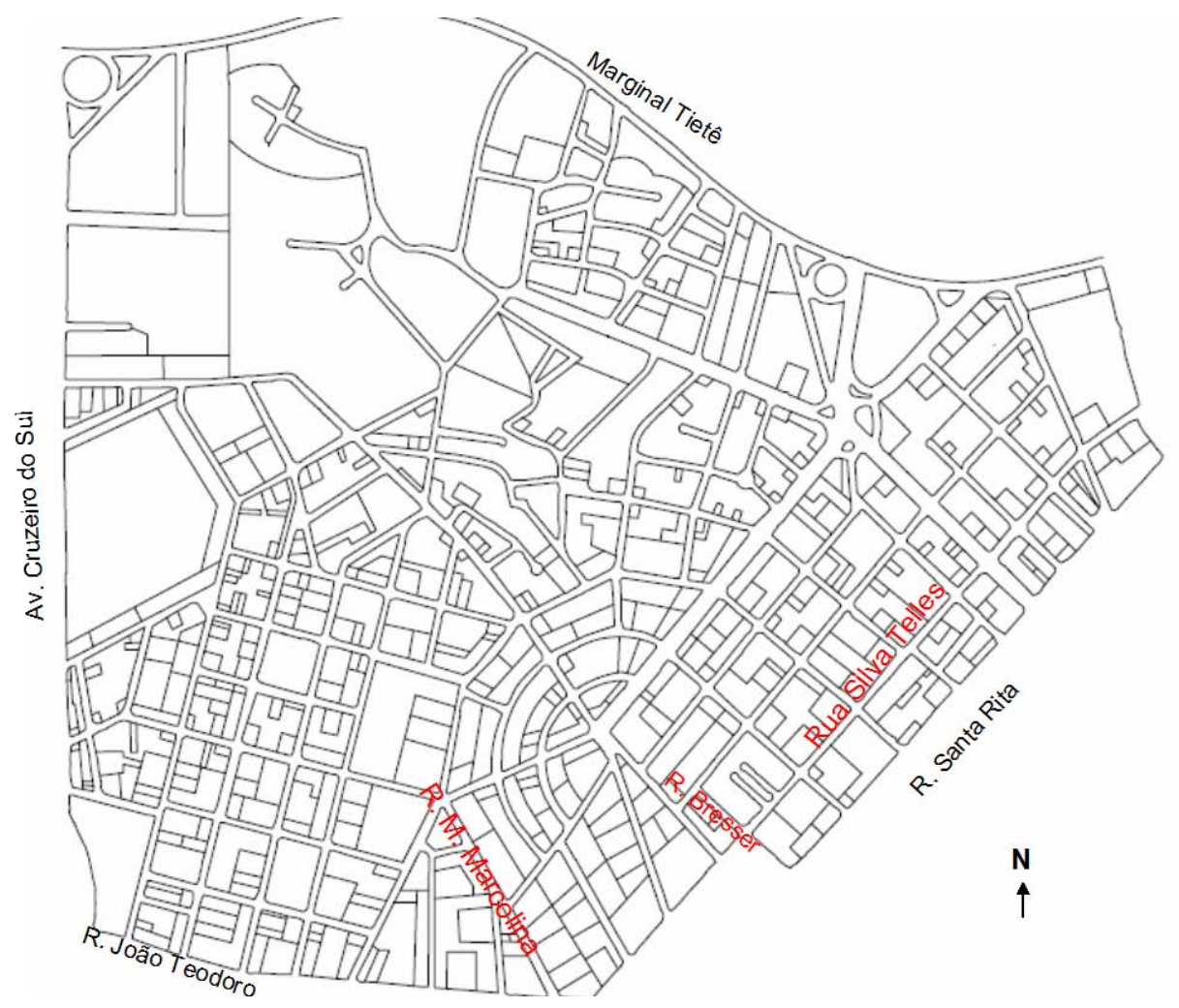




\section{Foto 22 - Rua Silva Telles}
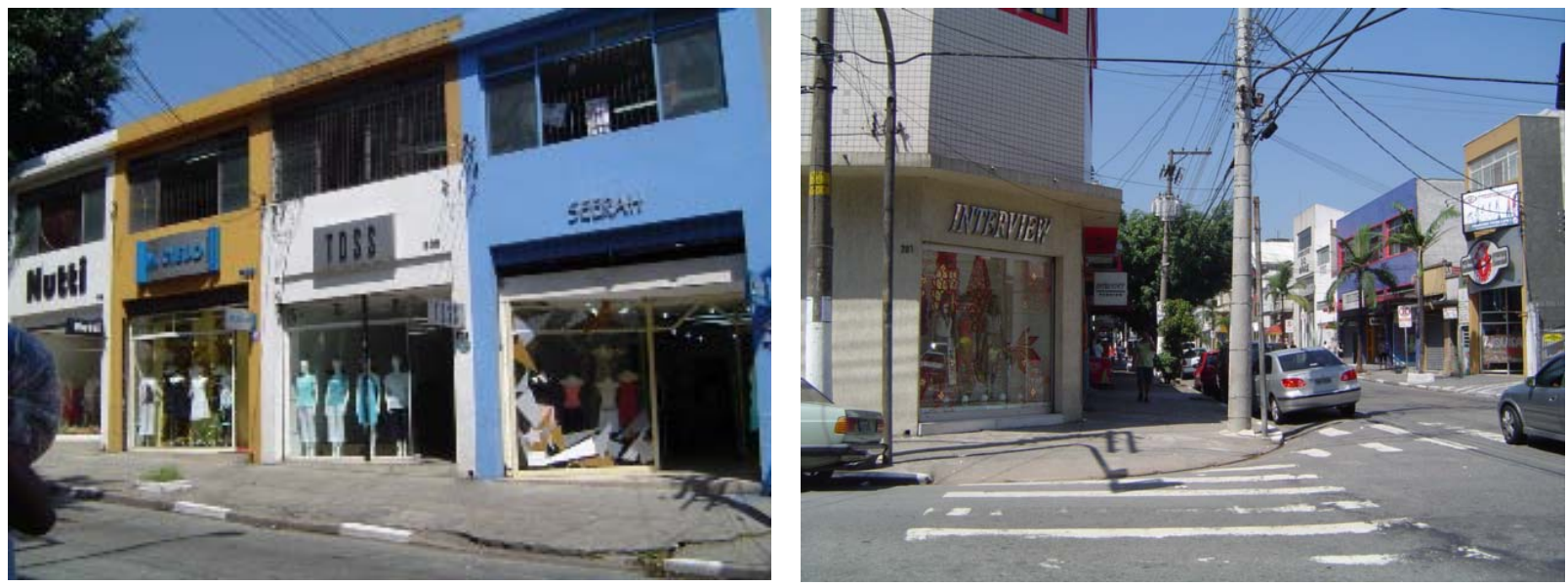

O bairro possui um shopping popular, o Shopping D (Foto 18), inaugurado em 1994, com 310 lojas, um grande número delas especializadas em roupas de festas. Mas também há cinemas, restaurantes e loja âncora. Há outro shopping de produtos "importados" - o Shopping Pari (Foto 23) - , localizado na antiga fábrica da Tostines, do chinês naturalizado brasileiro Law King Chong, sempre em apuros com as autoridades policiais, em razão de sua atividade ilegal.

\section{Foto 23 - Shopping D (popular) e Shopping Pari ("importados")}
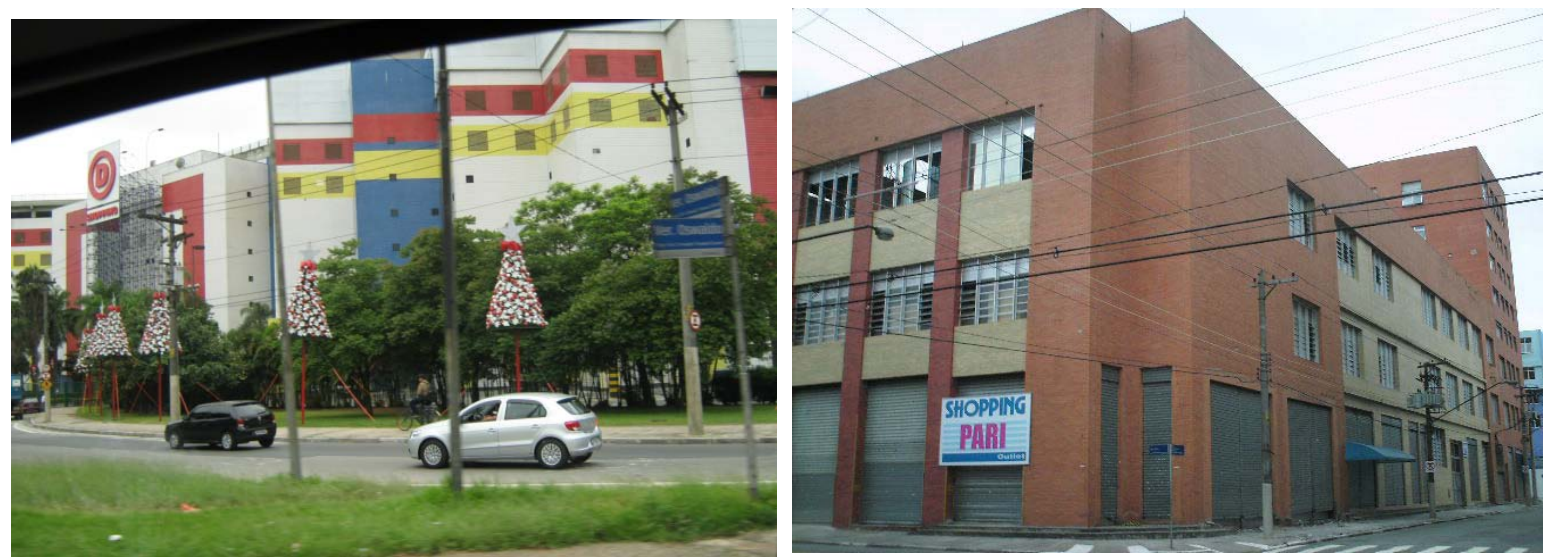
Há um número razoável de transportadoras, em terreno de grandes dimensões, que necessitam de área para estacionamento de veículos de grande porte, como caminhões e ônibus, localizadas na vizinhança da marginal Tietê (Foto 24).

\section{Foto 24 - Transportadora}

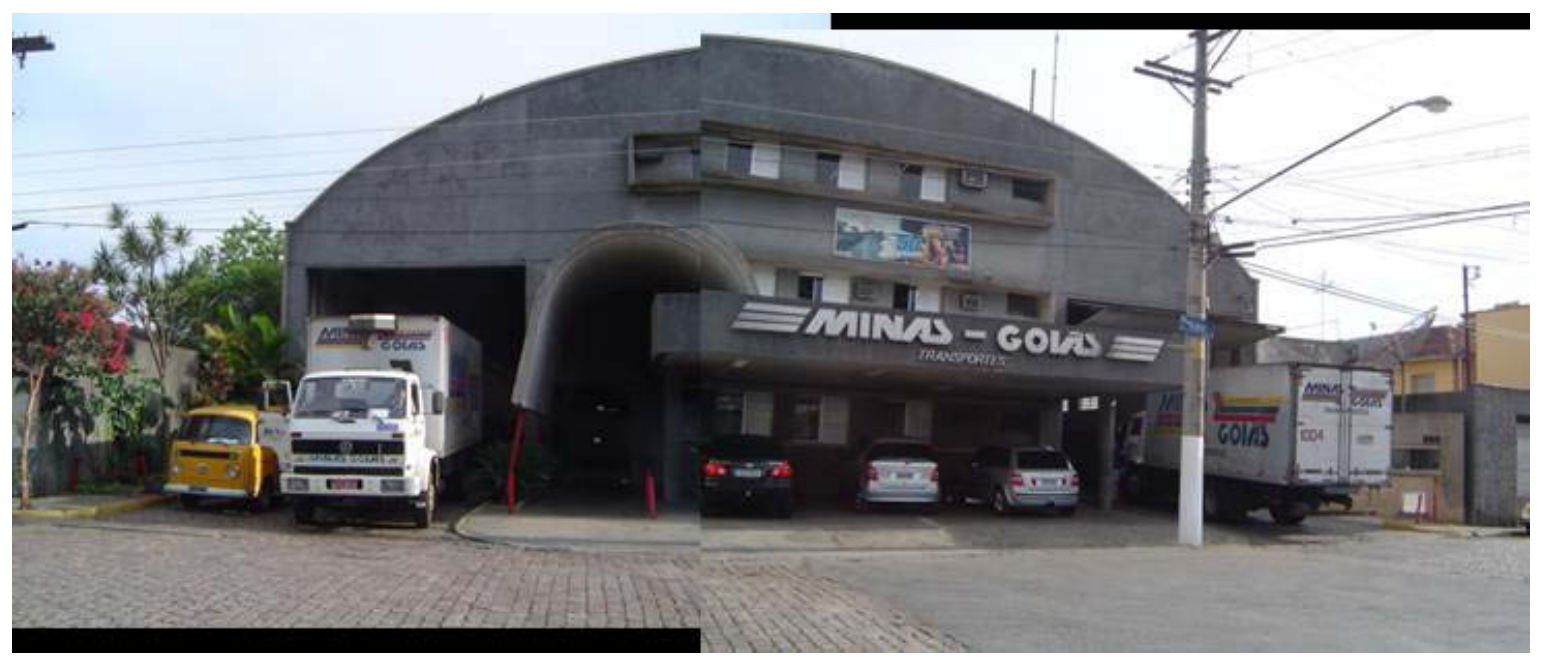

Há, ainda, no Pari aproximadamente 150 postos de gasolina (O Diário Popular, 1999). Chama a atenção o grande número de bares (71), cuja presença se revela em todas as quadras (Foto 25)

Em registro oficial do Sistema Unificado de Cadastro (SUC) da PMSP existem 103 empresas para 207 imóveis (SF/ PMSP, 2006). Na contagem manual há 1.112 imóveis na categoria comercial, serviço ou atacadista. 
Foto 25 - Bares
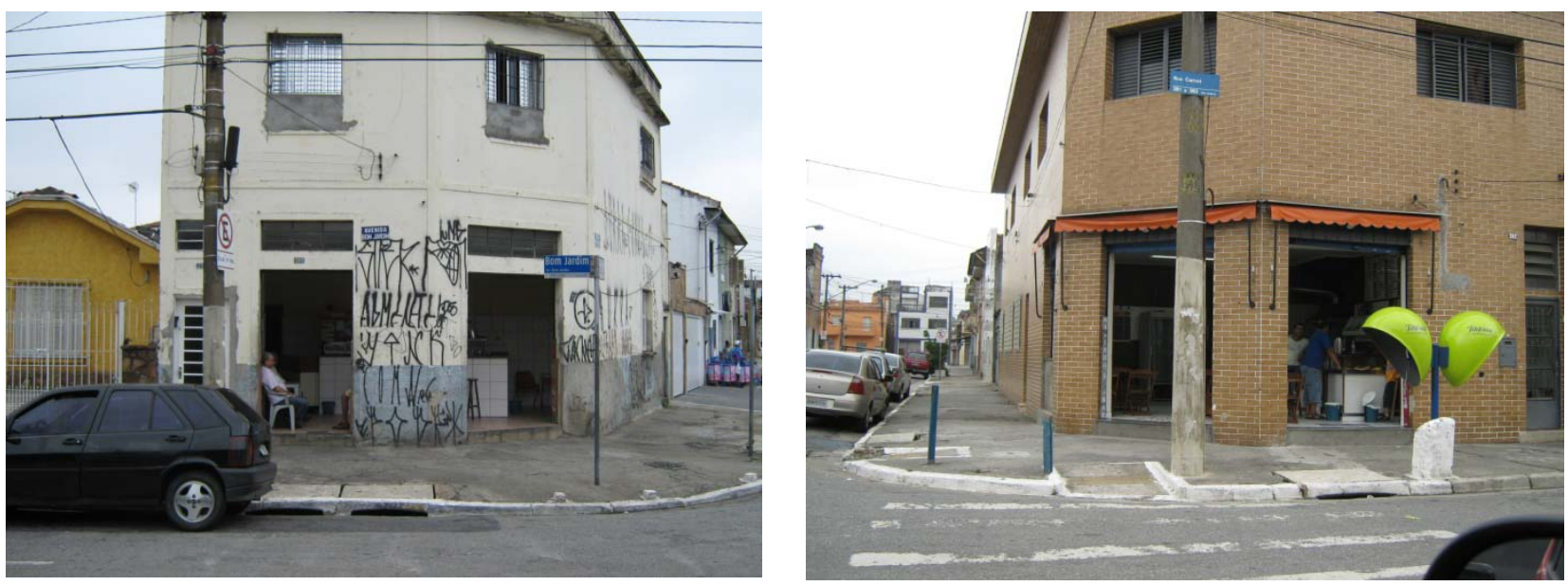

Foto 26 - Postos de gasolina
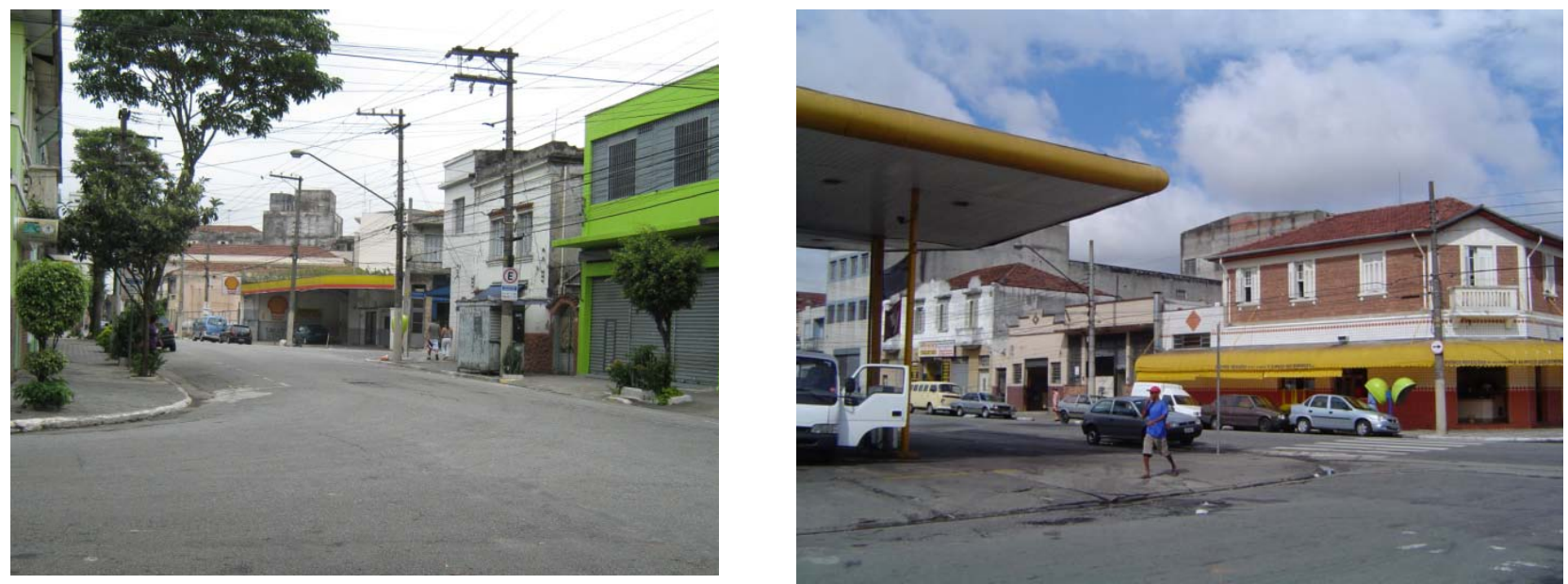

- Os usos institucionais - Equipamentos públicos

O potencial de urbanização, o conjunto de facilidades e as vantagens que os diversos terrenos - as localizações - do espaço urbano apresentam está também associado aos custos de urbanização envolvidos na produção de equipamentos coletivos e de infraestrutura. A produção do espaço urbano tem, por um lado no setor imobiliário privado e por outro nos órgãos públicos, a incumbência de implantar os equipamentos coletivos. O atendimento social dos equipamentos enfrenta os desajustes entre a 
dinâmica imobiliária e a produção e gestão dos equipamentos públicos coletivos urbanos.

A paisagem urbana do bairro do Pari reflete a sua forma de ocupação, com vários usos além dos comerciais e de serviços, como os institucionais: a área da Portuguesa de Desportos (foto 27), Academia da Polícia Militar (Foto 27), Escola Técnica Federal (quadra 105, Mapa 14), Clube da CMTC (idem), SPTrans, Museu do Transporte (idem), Clube Estrela do Pari (idem), CDMs, EMEI , EMEF, Eletropaulo, CET (setor 17, quadra 04), Clube Serra Morena (s17, quadra 04), SIURB (antiga SSO) PMSP (s17, q107), UBS (s17, q105, Mapa 14), SEMAB (idem), Grupo Escolar do Estado (s17, q82), além de abrigos de assistência social (Mapa 19).

\section{Foto 27 - Portuguesa de Desportos e Academia da Polícia Militar}
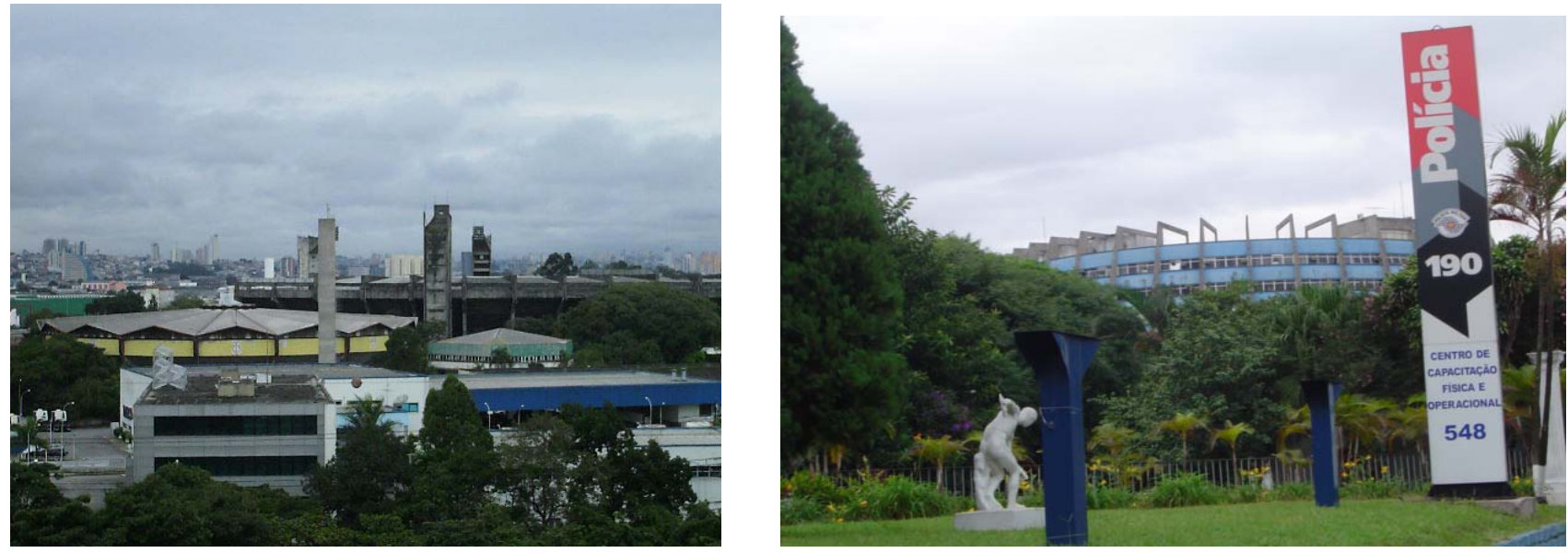
Mapa 19 - Quadras de áreas de usos institucionais

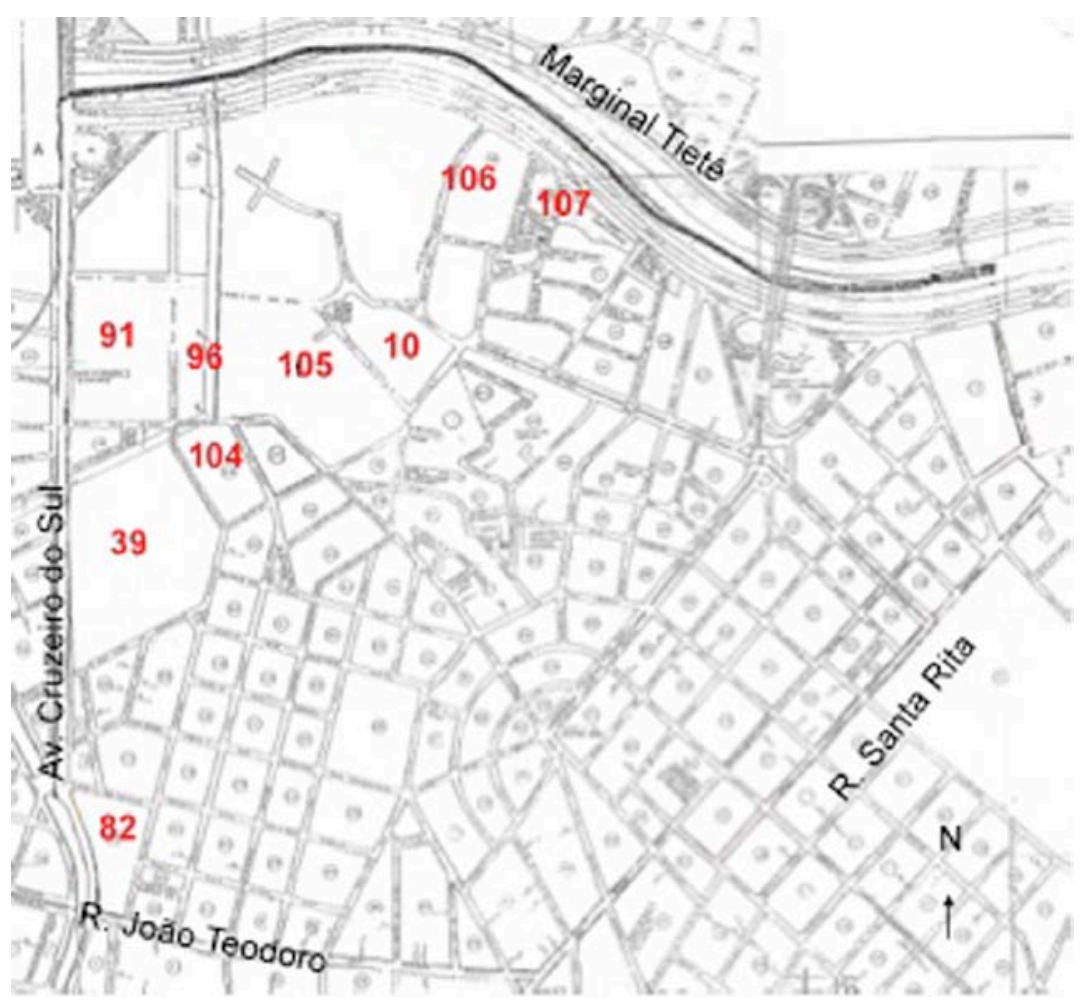

O almoxarifado do Metrô (quadra 105, Mapa 14 e 19) e a garagem da SPTrans na mesma quadra, apesar de serem usos integrantes do grupo indústria, como estão instalados em propriedades públicas, são considerados usos institucionais. Por sinal, essas eram áreas devolutas do antigo leito do rio Tietê. Dessa quadra toda, algumas áreas tornaram-se particulares, como o Shopping D e uma revendedora de caminhões localizada na marginal Tietê, ao lado da Portuguesa de Desportos, embora no mapa oficial de Bens Públicos do Geolog/PMSP constarem como áreas públicas (Mapa 15).

\section{Foto 28 - Praça Eduardo Rudge e Praça Psdre Bento}
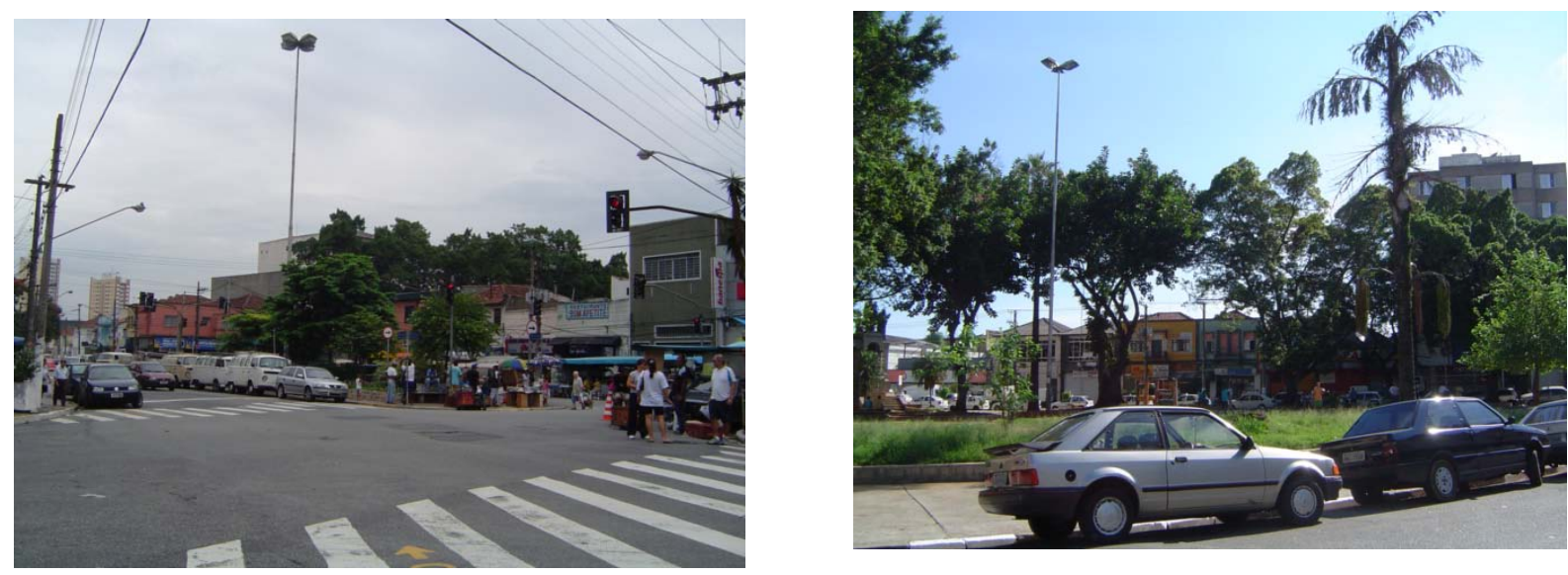
Apesar de vários clubes de várzea ainda persistirem no bairro, há poucas praças. No Canindé, das quatro praças, uma é usada pelos moradores de rua para fazerem sua higiene pessoal, o que inibe os moradores de utilizá-la; e à noite essa praça fica fechada. Outra praça, aberta de dia, é o lugar onde os catadores de lixo reciclável fazem a separação da coleta, e aos domingos é usada pelos bolivianos, que ali realizam a Feira Kantuta, onde se encontram, tocam músicas de seu país e colocam à venda comidas e artesanatos típicos (Foto 9). A terceira é a Praça República da Koreia, que fica na divisa do distrito com o Brás. E a última é a Praça Ilo Otonni, no entroncamento com a Ponte da Vila Guilherme, onde se localizam a Biblioteca e uma Escola Estadual.

Apesar de a diversidade de usos trazer dinamismo a um bairro, para que ele funcione como polo de atração, é preciso que haja uma densidade razoável da população e identificação entre os tipos de atividades e os tipos de moradores. Existem usos que dão mais dinamismo às ruas e aqueles que a fazem parecer um cemitério. É o caso de uma parte do Pari, o Canindé. Os usos ali implantados não dinamizam o bairro. Vejamos:

- a Portuguesa de Desportos foi implantada no início da década de 1960, numa antiga área de lagoas formadas pela extração de areia e argila, no fim da Rua Pascoal Ranieri, cuja continuação era denominada Estrada do Porto, limitada do outro lado pela Rua Azurita. Apesar de ser um clube, é particular e ali só entram os sócios, que em geral chegam de carro e não atuam no bairro, não andam pelo bairro, não consomem nada, enfim, não usam o bairro. Além disso, é uma área extremamente grande, voltada de um lado para a Marginal Tietê e segregada por um altíssimo muro que a isola do resto do bairro, apesar de ser um ponto de referência para a cidade.

Os outros dois clubes que são herança do futebol de várzea só funcionam aos sábados e domingos, nunca foram encontrados abertos nas visitas durante a semana. Como ocupam áreas grandes e também são isolados por muros altos, o ambiente criado é de isolamento, separação, vazio.

- Na Academia da Polícia Militar, que se localiza na Avenida Cruzeiro do Sul, o movimento é maior, mas como ele acontece dentro dos muros, o que se percebe do lado de fora é parecido com o que acontece na 
Portuguesa: um entra-e-sai de pessoas que não chega a alterar o dinamismo do lado exterior aos muros.

A repetição desse quadro nas outras áreas institucionais é nítida. Como são áreas sempre grandes e com horários de funcionamento restritos, sem movimentação a toda hora do dia, o resultado é uma falta de vitalidade na redondeza.

Além desses equipamentos, há:

O Colégio Santo Antônio do Pari, a escola mais tradicional do bairro, onde $20 \%$ dos estudantes, hoje, são de origem coreana.

1 escola de educação especial, 2 escolas de $1^{\circ}$ grau e 2 escolas de $2^{\circ}$ o grau.

Biblioteca Municipal Adelpha Figueiredo (Foto 29). Os edifícios da Biblioteca e do Colégio Estadual Frei Paulo Luigi são edifícios modernistas da década de 1960, localizados na Praça Ilo Otonni.

Pronto socorro, hospital, 2 creches, 2 Emeis.

1 faculdade Particular - Universidade São Francisco (Foto 30) e a FATEC (federal).

1 Delegacia de Polícia - 12aㅡ DP (foto 30). 


\section{Foto 29 - Biblioteca Adelpha Figueiredo}
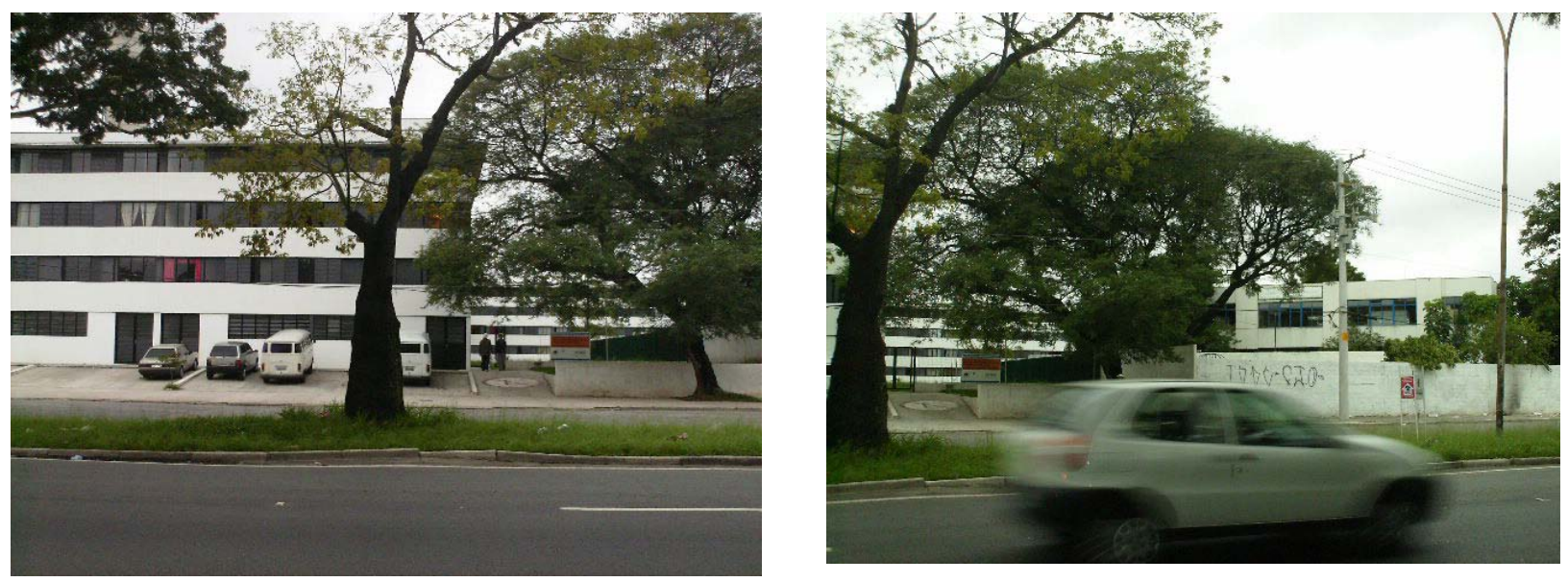

Foto 30 - Universidade São Francisco e Delegacia de Polícia - 12a DP
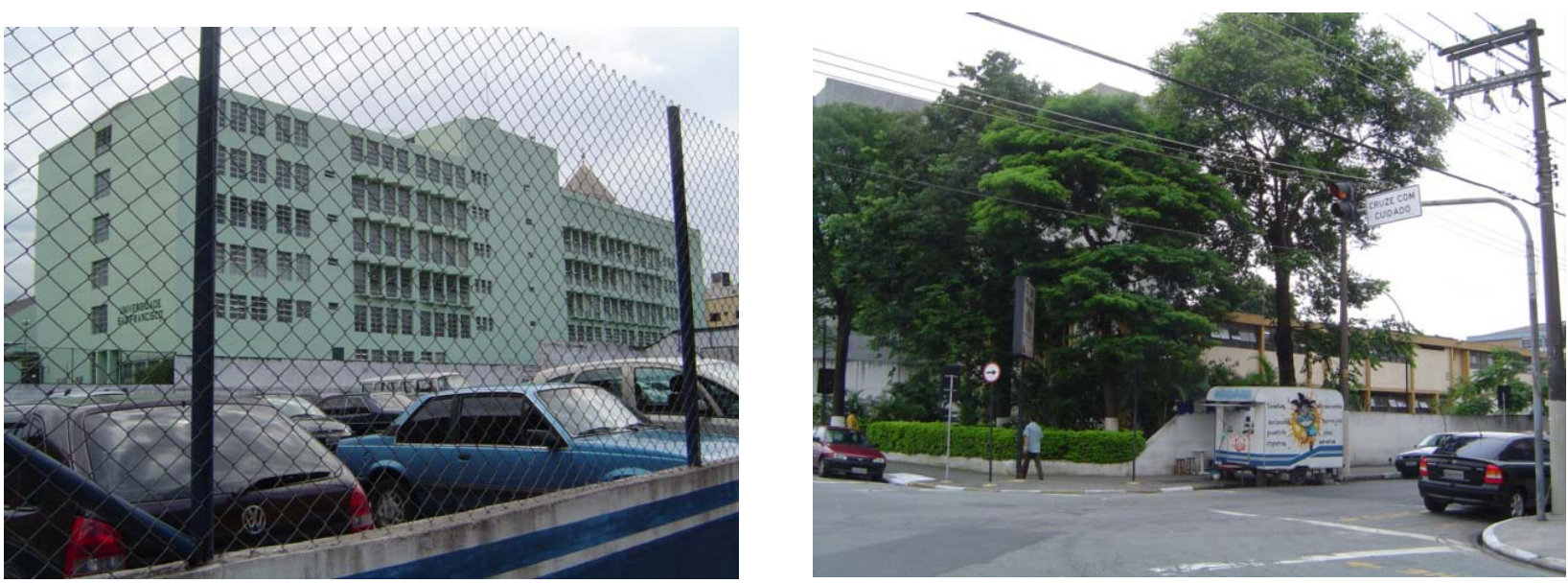

- A diversidade de uso do distrito

As práticas de cada lugar levam a diferentes ocupações e a diversas tipologias de usos do solo. Entre espaço privado (a casa) e espaço público (a rua) cria-se um espaço, um extrato peculiar que, depois das categorias "em casa" e "fora de casa", inscrevem as fronteiras do lugar. Não há nenhuma forma de enlace que liga, ao mesmo tempo, estruturalmente, o não familiar - fora de casa - ao familiar dentro do espaço privado. Um fragmento apresenta um contorno nítido, mas suas bordas são fluidas e não possuem delimitação territorial precisa. O bairro constitui aquele espaço intermediário entre o privado e o público, onde se desenvolve uma sociabilidade básica, mais ampla que a estabelecida pelo parentesco, porém mais densa, 
significativa e estável que as relações formais e individualizadas impostas pela sociedade.

A relação entre os diversos usos de uma região é determinada por uma diversidade que pode estimular ou atravancar a vitalidade urbana. 0 comportamento social da população, tanto moradora como frequentadora, está relacionado com essa vitalidade, assim como o desempenho econômico das atividades está condicionado à utilização do bairro. A relação da população entre os usos da área e a prática na vida real demonstra o grau de obsolescência ou vitalidade do bairro. Jane Jacobs, em seu livro Morte e vida de grandes cidades, enumera as condições para a diversidade urbana e ainda demonstra como a utilização de ruas, praças e calçadas dá um dinamismo especial ao bairro. Ela define:

Um bairro bem-sucedido é aquele que se mantém razoavelmente em dia com seus problemas, de modo que eles não o destruam. Um bairro malsucedido é aquele que se encontra sobrecarregado de deficiências e problemas e cada vez mais inerte diante deles (J acobs, 2003: 123).

Acrescenta, ainda, que as condições físicas das moradias não têm relação direta com o comportamento de seus moradores, mas relação com o espaço público. Mesmo quando vários urbanistas questionam a existência de bairros em metrópoles, há, ainda, muitos bairros com um dinamismo próprio, onde se pode reconhecer a mobilidade interna, como o trabalho, o dentista, os amigos, as lojas, as escolas etc. e que prendem os moradores. Os bairros da metrópole podem possuir a característica especial de atender pessoas de fora, atraindo-as com seus negócios e usos predominantes.

As combinações e misturas de usos são fundamentais para promover a vitalidade do bairro. A separação de usos, defendida por muitos urbanistas, segrega, fragmenta, isola as pessoas e traz monotonia. A mistura e interação de usos pode proporcionar mais segurança e contato entre as pessoas, trazendo vida e atratividade ao bairro.

A falta de comodidade e a falta de vida são apenas dois dos subprodutos da monotonia residencial (Jacobs, 2003: 158). 
É justamente a diversidade de usos que proporciona a uma metrópole a possibilidade de as pessoas, em contato umas com as outras, se manifestarem e desenvolverem atividades e habilidades diversas, expressarem necessidades e carências. E essa mesma diversidade traz uma dinâmica econômica importante para o bairro e também para a metrópole. Jacobs afirma que

Há quatro condições indispensáveis para gerar uma diversidade exuberante nas ruas e nos distritos: atender a mais de uma função principal; a maioria das quadras deve ser curta; deve ter uma combinação de edifício com idades e estados de conservação variados, e incluir boa porcentagem de prédios antigos, de modo a gerar rendimento econômico variado; deve haver densidade suficientemente alta de pessoas (Jacobs, 2003: 165).

Os usuários de um bairro consomem diversos produtos nesse espaço, como refeições, outros pequenos artigos e serviços em geral. A presença de pessoas ao longo de todo o dia proporciona uma vida estimulante ao bairro.

Outro aspecto importante é também conjugar os usos diurnos com os noturnos e os usos de fim de semana com os da semana. O uso principal é que dará ao bairro seu acento, mas as atividades que proporcionam diversidade no tempo e no espaço ajudarão a mantê-lo vivo e estimulado. Por exemplo, uma fábrica, mesmo funcionando no horário comercial, pode, nas horas de almoço ou de saída, provocar outras atividades, como o funcionamento de associações, igrejas ou outro tipo de agregação de pessoas.

O tempo transforma o espaço a todo instante. Os edifícios deteriorados podem ser atraentes para a geração seguinte. O espaço decadente sempre está à espera de uma oportunidade para se revitalizar. Muitas vezes, a falta de uniformidade de edifícios, com usos, alturas, padrões e idades diversas, recebe críticas que consideram essa falta de uniformidade como "bagunça". Essa crítica se fundamenta em um modelo criado por alguns urbanistas, que têm em vista que a cidade deve ser homogênea. Asseguram esses urbanistas que a aparência homogênea é 
mais agradável, mais esteticamente disciplinada. De outro ponto de vista, pode-se enxergar essa homogeneidade como monótona e entediante. A permissão e a diferença podem gerar um visual interessante, com características próprias. No entanto, existem alguns usos que dão a aparência de sujeira e desleixo, como ferros-velhos, oficinas descuidadas, bagunçadas, bares de esquina (que só vendem pinga), postos de gasolina, estacionamentos, garagens de caminhões grandes e ônibus, imóveis fechados e abandonados, favelas em condições deterioradas, cortiços e vazios urbanos. Esses usos dão a impressão de abandono ou de freqüência indesejada e transmitem um aspecto negativo do bairro. Os usos industriais também podem trazer uma impressão desgastante, impõem isolamento e seus espaços grandes quebram a continuidade da cidade.

Essas atividades podem ser forças negativas que contribuem para trazer ao bairro insegurança, monotonia, dispersão, prejudicando o fluxo de pessoas ao longo do dia e isolando os moradores. Além disso, contribui para não atrair a aplicação de recursos econômicos na área, impedindo a implantação de novos empreendimentos, pois o interesse por um espaço aumenta na razão direta de sua diversidade de usos, de vitalidade e do maior fluxo de pessoas.

Outro aspecto que traz desestímulo à vida urbana são os elementos que cortam o espaço, como linhas férreas, grandes rios e avenidas de tráfego pesado. Esse é o caso do Pari, próximo da linha férrea e que se confronta com o rio Tietê de um lado e com o Tamanduateí de outro. São três lados de uma forma praticamente quadrada, que isolam o bairro da cidade. Esses elementos interferem no espaço público, esvaziam-no, seccionam-no, impedem as pessoas de ultrapassá-los, segregam uma parte da outra e não interagem com o entorno.

Essa reflexão sobre a situação de um bairro inserido na metrópole pode ser espelhada nas palavras de Seabra, que discorre sobre o processo do bairro inserido na cidade que agora é metrópole:

É por isso que, quando os bairros já não eram enquanto tal, espaços de representação, começaram a vagar pela sociedade as representações sociais dos bairros. E, exatamente, porque foram 
eles (os bairros) na história urbana, uma realidade empírica vivida que experimentou a fragmentação do espaço e do tempo. A partir de tais indagações se pode constatar que o curso da urbanização entre nós foi dilacerante. Que a formação social e política da Cidade com seus bairros serviu aos desígnios de uma vida urbana em formação e que a urbanização de São Paulo, se encarada de um ponto de vista lógico, já mostrava os seus limites dada a impossibilidade de reproduzir, em sincronia, todos os elementos\momentos do seu próprio processo (SEABRA, 2005: 305).

O Pari se inscreveu na história da metrópole paulistana como um bairro operário, de moradias e usos múltiplos e hoje (2006) aprofunda-se essa relação, na luta contra o descaso e pela revitalização do lugar.

\section{I . I nfraestrutura e transporte}

A infraestrutura e o transporte estão conectados com o uso do solo e são elementos básicos da estrutura urbana de uma metrópole. O Pari, desde o início de sua formação, possuía uma quantidade considerável de atividades comerciais e industriais, no entanto em menor quantidade que seu bairro vizinho, o Brás. A estrutura da metrópole pode ser caracterizada por seus elementos bases: os subcentros de comércio e serviço e as áreas industriais (VILLAÇA, 1998: 12), elementos que têm destaque na área do Pari. Eles são unidos na metrópole por essa estrutura, tendo o transporte e as vias estruturais como bases imprescindíveis. O deslocamento das pessoas, enquanto portadoras da mercadoria força de trabalho ou enquanto consumidoras, é fundamental na estruturação do espaço intraurbano (VILLAÇA, 1998:23), que tem na localização um elemento essencial. A localização urbana é determinada por dois atributos:

- Uma rede de infraestrutura: vias, redes de água, esgoto, energia etc.

- Possibilidades de transporte de produtos de um ponto a outro, de pessoas e de comunicação. A necessidade de deslocamento de pessoas 
deve dominar a de comunicação na estruturação do espaço intraurbano (idem: 23).

A história do transporte no Pari começa em 1925, quando era contornado pelo trajeto do bonde denominado Canindé, que trafegava pelas ruas São Caetano, Monsenhor de Andrade e Oriente, mas não adentrava no bairro.

Em 1954, havia já uma garagem de bondes na Rua Padre Vieira esquina com Rua Araguaia, que depois passou a receber ônibus da CMTC e hoje é da SPTrans. Além dela, havia outra garagem de bondes que serviam o Brás, na Rua Santa Rita.

O Pari está localizado na proximidade da linha norte-sul do metrô, tendo a Estação Armênia a 300 metros (mapa 20). A área no entorno dessa estação sofre uma deterioração física muito acentuada, razão pela qual, talvez, ela não represente uma opção para o morador do Canindé - Pari. Outra razão pode ser o fato de a Avenida Cruzeiro do Sul ser uma barreira, uma via que decepa essa união entre o bairro e a Estação. O fluxo de veículos e a dificuldade em atravessar a avenida, devido à rapidez da troca de faróis, tornam-se um obstáculo para a conexão dos espaços - afinal, a distância de 300 metros é pequena como justificativa para o não-uso do metrô.

\section{Mapa 20 - Estação Armênia a $\mathbf{3 0 0}$ metros}




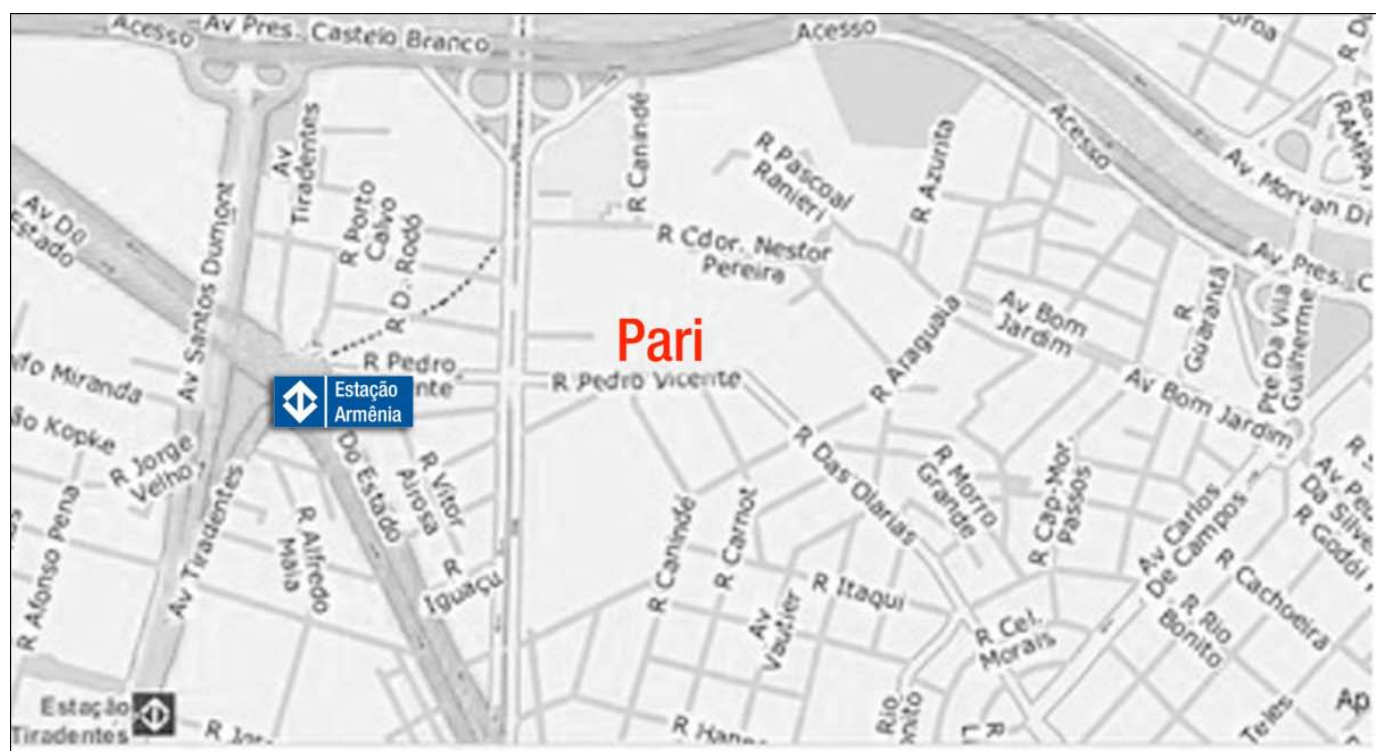

A localização do Pari, no entanto, pode ser considerada muito boa em se tratando de acessibilidade. E isso é muito importante, como diz Villaça no trecho que se segue:

A terra urbana só interessa enquanto "terra-localização" (Villaça, 1985:5), ou seja, enquanto meio de acesso a todo o sistema urbano, a toda a cidade. A acessibilidade é o valor de uso mais importante para a terra urbana, embora toda e qualquer terra o tenha em maior, ou menor grau. Os diferentes pontos do espaço urbano têm diferentes acessibilidades a todo o conjunto da cidade. A acessibilidade de um terreno ao conjunto urbano revela a quantidade de trabalho socialmente necessário despendido em sua produção (VILLAÇA, 1998: 74).

Ter vantagem de localização em relação a outros faz de um espaço um "ponto" de valor. O "ponto" é o lugar que se disputa para alocar um comércio, uma indústria ou residência, dependendo do lugar. A apropriação dessa vantagem domina a estrutura urbana. As transformações dos pontos alteram a estrutura espacial da cidade (VI LLAÇA, idem). 
O custo e o tempo de deslocamento do Pari até o centro antigo da cidade é muito pequeno. Qual então o motivo que o torna um bairro não atraente para o mercado imobiliário? O lugar social do Pari não é disputado por outras regiões, por isso não há razões para torná-lo mais valorizado? 0 Pari não polariza, então não há o valor simbólico ${ }^{5}$.

Harvey afirma que as camadas populares são mais prisioneiras do espaço do que as camadas de mais alta renda, pois a mobilidade destas é bem maior. Os ricos podem comandar o espaço, enquanto os pobres são prisioneiros dele (HARVEY, 1980:146). É claro que o próprio Shopping Center depende, para seu sucesso, de um bom "ponto", de uma boa "localização". A estruturação do espaço se dá na disputa dessas localizações, sob a ação do conflito de classes em torno das vantagens do espaço urbano, enquanto produto do trabalho.

Não basta que haja acessibilidade a um local apenas pelo transporte individual, é obrigatório que o transporte de massa chegue ao destino escolhido. A luta de classes pelo domínio do espaço, na estrutura urbana, não se esgota no transporte. Se a pior localização é aquela na qual há dependência em relação ao transporte público, torna-se maior, ainda, a dependência da estrutura territorial em relação às estruturas sociais, políticas e ideológicas. Os elementos da estrutura territorial urbana com os elementos invisíveis da estrutura social podem ser mais fortes e mais produtivos de "localizações".

Se o mercado imobiliário distribui as acessibilidades na cidade, onde não há interesse do mercado imobiliário elas não são criadas? A acessibilidade se produz em dois momentos: primeiro, durante a própria produção/consumo dos espaços, isto é, dos pontos a serem interligados. Depois, pela atuação sobre o sistema de transporte que interliga os pontos produzidos. O Pari não é "o" ponto. Não carrega a carga ideológica de "bom bairro", como a Vila Madalena ou Moema - logo, é descartado da atuação do mercado imobiliário.

O melhor meio de abreviar o tempo de circulação de pessoas e de mercadorias é investindo em transporte, atuando assim sobre o espaço para reduzir o tempo. As transformações em transporte e comunicação alteram a

\footnotetext{
${ }^{5}$ Entende-se por valor simbólico de um espaço o grau de representação que este possui perante a sociedade.
} 
posição relativa de cada ponto no espaço (VILLAÇA, 1998). Não existe equilíbrio espacial, portanto sempre se devem criar oportunidades de obter lucros extraordinários de localização.

A localização de um bairro desempenha papel fundamental nas relações estruturais e dinâmicas da formação e do crescimento da cidade. Ao abordar pelo ângulo da formação e evolução da cidade a localização de um bairro revela sua relação com a estrutura da cidade.

A expansão espacial da cidade de São Paulo se deu pela ocupação do solo ao longo das principais vias de penetração ligando a produção industrial à fonte das matérias-primas e aos mercados consumidores. Esse processo desencadeou nas vias estruturais mais centrais da cidade uma elevação dos preços do solo (SINGER, 1974).

O valor de um terreno é determinado em princípio, pela distância de sua localização ao centro da cidade e ao centro de bairro mais próximo (SINGER, 1974: 74).

O distrito do Pari, localizado no interstício da marginal Tietê e a Avenida Cruzeiro do Sul, tem como prolongamento a Avenida do Estado, que por meio das vias que dela saem atinge a cidade de São Caetano, dando acesso ao ABCD paulista. De outro lado, há a Marginal Tietê, que une o norte do país ao interior do estado, e as estradas de ferro, que por um tempo foram as principais transportadoras de mercadorias. Essa localização é muito especial para a metrópole, além de ser única.

O Pari se destaca por ser um bairro secundário do centro principal e sua localização, por um determinado período, levou a uma disputa por espaço, entre moradores e empresas, frente ao número de serviços ofertados: transporte, energia, água e comunicações. Em razão dessa oferta, criou-se a demanda por equipamentos públicos essenciais à vida cotidiana de seus moradores, como escolas, biblioteca e igrejas, que foram então instalados. E todo esse processo desencadeou também o surgimento de comércios varejistas e atacadistas e até de indústrias.

A divisão do trabalho condiciona determinadas relações entre os indivíduos e grupos da sociedade que são reproduzidas no espaço. A 
demanda por terrenos para a construção de indústrias é acompanhada por uma demanda suplementar para residências e estabelecimentos comerciais (SINGER, 1974). São Paulo integrou suas funções de centro comercial em sua economia industrial.

O primeiro subcentro a surgir no Brasil foi o Brás (VILLAÇA, 1998: 294), na década de 1920. E o Pari, como bairro vizinho, foi favorecido, pois os trabalhadores do Brás procuravam habitação nos locais mais próximos, e isso trouxe crescimento ao Pari. E os bairros passaram a competir entre si para acolher as atividades mais lucrativas. Em 1940 as lojas, os cinemas e os restaurantes do Brás se incluíam entre os maiores da cidade, e nos anos 50, suas lojas abriram filiais no centro da cidade (idem).

Infere-se, então, que a localização do Pari pode ser considerada importante na estrutura da metrópole; seu desempenho nas funções urbanas é intenso, as principais vias estruturais da cidade passam junto ao distrito e o principal meio de transporte de massa tem estação próximo ao Pari. Mas, paradoxalmente o bairro não é "o" ponto.

À medida que o processo de produção do espaço urbano estende suas atividades econômicas e distribui sua população, vão-se ampliando também as redes de transporte e de infraestrutura, alterando as vantagens relativas das diferentes parcelas do tecido urbano. Mas todas essas mudanças não afetaram o valor simbólico do Pari.

Se por um lado a localização do Pari é privilegiada na estrutura da metrópole, por outro o sistema de transporte de São Paulo tem uma configuração fortemente rádio-concêntrica e uma parca rede de transporte de massa. Assim, uma das vias que formam o perímetro que envolve a coroa central do município, a Marginal Tietê, contorna o Pari ao norte. Ela é elemento fundamental na estrutura da metrópole, ligando as rodovias que vêm do interior do Estado às que se direcionam ao nordeste do país. Ao sul do distrito, a Rua J oão Teodoro funciona como uma via radial que liga a Zona Leste ao Centro. Esse modelo reforçou e consolidou o uso de veículos privados. E elementos que cortam o espaço, como linhas férreas, grandes rios e avenidas pesadas trazem desestímulo à circulação e aridez à paisagem urbana. Esse é o caso do Pari, próximo da linha férrea e se confrontando com rio Tietê de um lado, de outro com o Tamanduateí. São três lados de 
uma forma praticamente quadrada que isolam sua área. Esses elementos interferem no espaço público, esvaziam-no, seccionam-no, impedem as pessoas de ultrapassá-los, segregam uma parte da outra e não interagem com a redondeza.

As ruas têm intenso tráfego de caminhões, tanto em razão do grande número de transportadoras, quanto pelas indústrias e depósitos de materiais em geral. Isso dificulta o movimento de pedestres, que atravessam as ruas com a máxima cautela. Os moradores em geral se locomovem a pé pelo bairro, pois não existe ônibus de circulação interna (Mapa 21).

\section{Mapa 21 - Linhas de ônibus - Distrito do Pari, 2006}

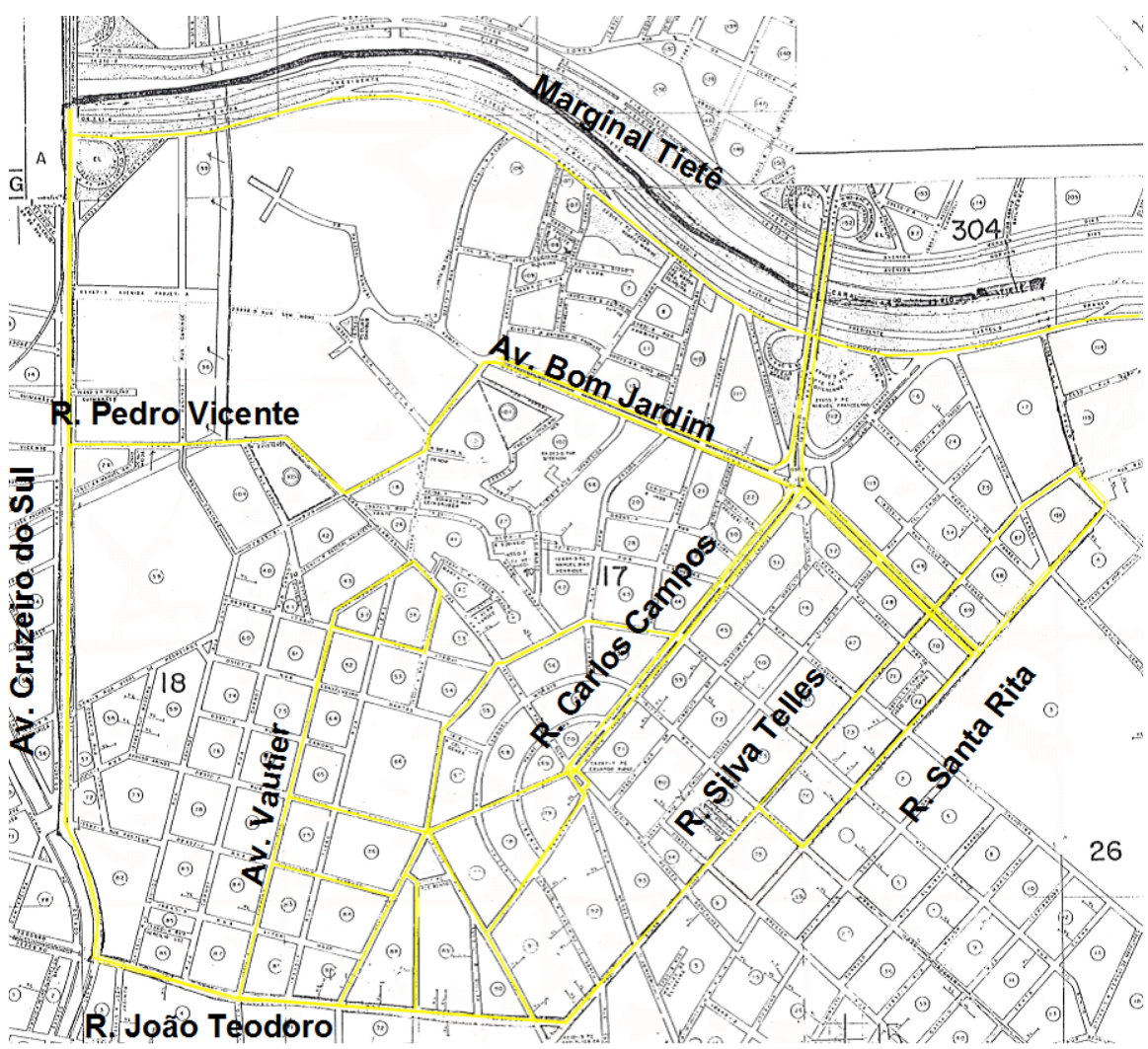

O distrito do Pari fica a $3 \mathrm{~km}$ do Centro e seu centro nevrálgico, a Rua Silva Telles, a 1.500 metros da Estação Armênia. Mesmo assim o principal meio de deslocamento é o transporte individual. As linhas de ônibus (Mapa 22) que penetram no bairro são apenas duas: Vila Sabrina e Jardim Japão. As outras passam nas extremidades do distrito, ou pela Avenida Cruzeiro do 
Sul, ou margeando o Tietê, pela Rua Silva Telles e Rua João Teodoro. Existem diversos meios de transporte públicos para se alcançar o Pari, além do transporte individual; no entanto, esses meios parecem não ser eficientes. E isso se deve mais a uma questão de comodismo da população que à falta de informação sobre as distâncias entre o bairro e a estação de metrô ou linhas de ônibus. Pode-se afirmar que a distância a ser percorrida, apesar de numericamente baixa, ou seja de 300m (até a avenida Cruzeiro do Sul), $700 \mathrm{~m}$ (ao centro do distrito) e 1.500m ( até a rua Silva Telles), do início do distrito até considerada pelos moradores como demasiada para se caminhar. Fica uma controvérsia: até que ponto essa ideia pode ser considerada como cultural e não realmente prática? Os deslocamentos no bairro são preferencialmente a pé, $71,3 \%$ da população vai trabalhar à pé (Pesquisa OD ano). Para a população de menor nível de renda, os deslocamentos são condicionados pelos transportes e pelas viagens trabalhoresidência.

O Pari não possui vias estruturais internas, o que o configura como uma ilha entre os bairros ao norte do rio Tietê e a leste do núcleo central. A pavimentação cobre $100 \%$ das vias existentes. $85 \%$ tem coleta de esgoto e $100 \%$, água encanada.

Um dos problemas mais graves do distrito são as enchentes, que trazem prejuízos e grandes dificuldades à população moradora. Mas o Pari ainda guarda hábitos de um bairro em que os moradores exercitam a solidariedade, socorrendo seus vizinhos das enchentes e se reunindo na Igreja. 


\section{2.f. História da atividade imobiliária}

\section{I - I ntrodução}

O objetivo deste item é verificar a distribuição da propriedade imobiliária e a evolução do valor venal do terreno, no período entre 1953 a 2006, no distrito do Pari. Compreende duas pesquisas de campo: a primeira levantou o número de imóveis do Pari e seus proprietários (anexo 1) e a segunda, os valores venais dos lotes em 1953, 1966, 1978, 1990, 2000 e 2006, e sua correção monetária para o ano de 2006 (anexo 2).

O diagnóstico efetuado a partir dos referidos dados demonstra como a evolução histórica permite marcar momentos de estagnação urbana no Pari. Nossa hipótese é que um dos fatores que causaram a estagnação no Pari foi a existência de concentração de propriedades imobiliárias em mãos de poucos. Acreditamos que a concentração de imóveis nas mãos de poucos impede o acesso democrático à propriedade da terra, criando um monopólio de controle sobre os preços de venda e de locação. Essa situação atrofia a liberdade do mercado imobiliário, já que sua dinâmica é dominada por poucos. Procuraremos verificar, a partir da análise da concentração de propriedade da terra urbana e a evolução de seus preços, se esses elementos são - ou não - constitutivos da existência da renda fundiária urbana.

Embora este trabalho se apoie em dados reais, sua elaboração resultou, também, do debate teórico sobre a existência ou não da renda da terra urbana, tema sobre o qual há controvérsias. Entendemos que a análise feita por Harvey (1990), a ser explicitada mais adiante, pode ser assumida, mas há autores, como Deak (2001), que afirmam não existir renda da terra urbana, que seria uma categoria relativa do modo de produção feudal, fenômeno essencialmente rural. Há autores que consideram a ocorrência de valorização urbana, mas não renda da terra urbana:

A maioria das pessoas concordaria que a valorização da terra urbana seria oriunda de investimentos públicos realizados no entorno, seja pavimentação de vias, execução de infraestrutura de saneamento, equipamentos social e 
especialmente a infra-estrutura de transporte. Isso é verdade, mas não é toda verdade. Outros acrescentariam “o crescimento de cidade" como uma explicação adicional para a valorização. Isso já parece mais interessante mas resta compreender em que e por que o "crescimento da cidade" valorizaria seus terrenos e, principalmente, por que valoriza uns mais que outros (já que todos foram equalizados quanto a investimentos públicos). Também fica por investigar e entender por que o trabalho realizado fora de um lote cria valor nesse lote (VILLAÇA, 1985: 9).

A retenção de propriedades imobiliárias por poucos é, também, a base para a presença da especulação imobiliária, que assegura ou extrapola o valor da propriedade. Porém, essa especulação é vista pela sociedade como um fenômeno natural. Negar o "direito" (privilégio) de possuir o número de propriedades ao alcance do capital é interpretado, pelo senso comum, como uma ameaça aos interesses capitalistas.

A mão de obra sub-remunerada não tem condições de adquirir ou alugar uma casa, pois o custo da mercadoria habitação transcende em muito o preço da força de trabalho (KOWARICK, 1994: 74).

...A maior parcela dos ganhos dos trabalhadores precisava ser canalizada para gastos com alimentação e assim muito pouco sobrava para dispêndios com moradia. (...) Isto porque o aluguel de habitações adequadas correspondia, na melhor das hipóteses, a mais da metade da remuneração auferida pelos trabalhadores (idem: 75).

O apego aos privilégios é fruto de uma herança escravocrata nos quais os senhores determinavam os valores sociais e espirituais, moldando a futura burguesia em ascensão.

Daí o caráter que a urbanização iria assumir (de disseminação de privilégios em áreas cada vez maiores) e o aparecimento de formas agressivas de "dualidade ética", nas quais o nosso grupo com freqüência se reduzia à família dos interessados e o grupo dos outros acabava sendo a coletividade como um todo (FERNANDES, 2006:46). 
A propriedade é o poder, a capacidade de controlar e de impor a própria vontade, com uma característica de exclusividade (MARX, 1985) ${ }^{1}$. A propriedade configura-se como uma estrutura e instrumento de poder econômico e a especulação imobiliária é cada vez mais fortalecida em virtude da enorme demanda por moradias e pode, até, ser estimulada nos bairros operários. Contudo, o acaso e a necessidade são dois aspectos igualmente objetivos, contraditórios e dialeticamente unidos, na sociedade. E a propriedade imobiliária é, sobretudo, uma questão social porque, ao se acumular riqueza com a concentração de propriedades, aumenta a desigualdade social e negam-se direitos aos não-proprietários, de forma igualitária.

O valor de uso na sociedade capitalista é secundário, mas, para aqueles que não possuem uma moradia digna, a propriedade é essencial para a sobrevivência. Com o acirramento do capitalismo e as permanentes crises cíclicas, o valor de troca se sobrepõe cada vez mais ao valor de uso. Isso significa que, para usufruir determinados atributos do lugar, é preciso realizar, antes de tudo, seu valor de troca. Assim, os processos de valorização do espaço passam, necessariamente, pela mercantilização do próprio espaço, concretamente pela mercantilização dos lugares (SEABRA, 1988: 101).

No capitalismo a propriedade imobiliária geralmente é entendida como uma mercadoria como outra qualquer, não se levando em conta seu valor de uso e sua circunstância social.

\begin{abstract}
As necessidades sociais são tratadas pelo Estado capitalista somente em função das necessidades da burguesia. O sistema contratual (jurídico), que o Estado mantém e aperfeiçoa enquanto poder (político) repousa na propriedade privada, a da terra (propriedade imobiliária) e a do dinheiro (propriedade mobiliária) (Lefèbvre, 1999: 138).
\end{abstract}

O setor imobiliário paulistano é composto de setores capitalistas de produção de moradias para as camadas abastada e média da população e de imóveis para o setor de negócios. O setor de construção de moradia

\footnotetext{
${ }^{1}$ Marx afirma: ... “o poder descomunal a que essa propriedade fundiária dá origem, quando reunida na mesma mão com o capital industrial, habilita esta a praticamente excluir da Terra, enquanto sua moradia, os trabalhadores em luta pelo salário". (citando Engels em A greve de Crowlington). Lage der arbeitenden Klasse in England, p.307. (1892) (MARX, 1985:237).
} 
realizado pelo Poder Público é para atendimento de uma faixa de salário mais baixa, muitas vezes em loteamentos clandestinos ou áreas de ocupação. Há, ainda, um mercado imobiliário de locação formal e para sublocação de cômodos ou casas apropriadas à habitação coletiva, que em São Paulo não é pequeno.

O papel da habitação popular enquanto elemento fundamental para rebaixar os custos de reprodução da força de trabalho, malgrado suas semelhanças aparentes nos primórdios da industrialização e nos momentos atuais, esconde mecanismos extremamente diversos que são ligados à modalidade de exploração do trabalho, ao papel do Estado e à própria forma de estruturação da cidade, antes concentrada e agora dispersa em amplas e rarefeitas áreas de uma Metrópole, que a partir de 1950 ampliou seu padrão periférico de crescimento urbano (KOWARICK, 1994:50).

Hoje, um imóvel não é apenas um patrimônio, tornou-se um papel negociável no mercado de ações. A crescente tendência de tratar um imóvel como um bem puramente financeiro é o ponto crucial para encontrar sua transição à forma puramente capitalista da propriedade privada.

Sem crescimento, a cidade desvaloriza-se e, junto com ela, desvalorizam-se os ativos nela imobilizadas - propriedades, comércio, serviço às empresas e às pessoas, anúncios no jornal, rádio e TV, salários -, enfim, a cidade perde valor como qualquer outra mercadoria, quando não encontra demanda no mercado e não consegue passar adiante os efeitos da crise de sobre-acumulação (FERNANDES, 2001: 36).

$\mathrm{Na}$ pesquisa que realizamos no distrito do Pari, as informações sobre as propriedades indicam que sua concentração em mãos de poucos é uma realidade. A imobilidade de propriedades não faz o mercado girar, produzindo poucos negócios no bairro e deteriorando os imóveis fisicamente. Uma das principais bases estruturais do capitalismo se encontra na concentração da propriedade porque concentrar propriedades traz poder aos proprietários e expande seu capital. O capitalismo é 
expansionista, concentrador e centralizador. E, a cada estágio, a história do modo de produção capitalista se territorializa pelo mundo, dominando os lugares e a sociedade, gerando características peculiares, que desembocam em transformações contínuas. Cada lugar cumpre uma função determinada na divisão territorial e se diferencia por suas funções. O urbano é um retrato que expressa essa condição mais geral da economia e da sociedade.

O urbano, de certa forma, é hoje a expressão da forma de organização da atividade econômica, de um lado, que cria uma certa estrutura de classes, e, do lado do regime político, da falta de voz das classes populares, direcionando, portanto os gastos do Estado, todo seu poder, desse ponto de vista de investimento, para atender, sobretudo aos reclamos advindos das demandas das classes médias (OLIVEIRA, 1982:51).

Consideramos que para poder demonstrar pelo menos um dos fatores indicados como causa da estagnação do Pari, é fundamental tentar compreender mais estritamente a valorização imobiliária ou/e a renda auferida pelos proprietários. A questão é colocada no presente trabalho de forma prática, no entanto ela é antes de tudo teórica.

No Pari, a atividade imobiliária se restringe àqueles que detêm e acumulam propriedades imobiliárias para obter renda ou para simplesmente especular, ou seja, esperar a valorização dos imóveis; e aos que retêm propriedades sem colocá-los em uso (para alugar ou vender), sem a preocupação de reformar ou restaurar ou mesmo manter seus imóveis em boas condições de habitabilidade. O mercado imobiliário - de novas edificações para atividades não residenciais e a construção de infraestrutura - é bastante insignificante.

Para iniciar a análise da questão sobre a valorização e a concentração de propriedades imobiliárias é importante conhecer como se deu a realização da propriedade privada na metrópole paulistana

A história da sociedade urbana indica que a propriedade da terra cria uma desigualdade crescente entre os proprietários e os nãoproprietários, apresentando-se como a oposição irredutível entre a liberdade e a igualdade. O processo de realização da propriedade privada fundiária e imobiliária em São Paulo é a expressão concreta dessa 
afirmação. O domínio da propriedade do solo, em primeiro lugar, e em seguida, da imobiliária, no desenvolvimento do capitalismo, fortalece-se na desigualdade da sociedade e cria novas formas para acentuar as diferenças entre as classes.

O processo de acesso à propriedade privada se deu dentro de especificidades singulares em cada país capitalista. Cada país teve seu viés cultural, social, econômico e político, os quais deram conformação ao acesso à propriedade. Essa conjuntura histórica particularizou a forma de realização da propriedade privada da terra ou imobiliária.

A partir do momento em que a terra se transformou em mercadoria particular no mercado imobiliário, a aquisição desse bem passa a ter um valor especial a cada estágio do capitalismo, até tomar sua última forma em título de propriedade por um ato negociável no mercado (financeiro), assumindo-se como um papel fictício na circulação capitalista, sendo a garantia contratual de troca entre compradores e vendedores. Do início do processo até hoje, houve várias alterações dessa mercadoria essencial para a vida humana.

A história da propriedade da terra no Brasil e em particular em São Paulo teve sempre a participação especial da classe dominante. As elites brasileiras sempre encararam o Estado como um meio para realizar e promover seus interesses internos, para atingir seus fins; e com a institucionalização da propriedade da terra não foi diferente.

A cidade de São Paulo possui uma localização diferente da maioria das primeiras cidades do Brasil. Não se situa em área litorânea, como outras cidades com maior atividade econômica na época de sua fundação. Desde então, constituiu exceção às regras de ocupação do território brasileiro, tratando-se de uma área de planalto, que era um ponto de encontro do sistema viário que levava às outras regiões mais ricas economicamente. Sua situação geográfica privilegiada possibilitou a circulação dos capitais ligados à exportação e adquiriu condições vantajosas de suporte físico da produção industrial. Antes mesmo que a intensa produção cafeeira no oeste paulista tivesse início, o crescimento econômico de São Paulo teve um avanço em consequência da vinda da Família Real. Pois, com o fechamento dos portos da capitania, as atividades exportadoras se concentraram no porto de Santos, elevando o giro de capitais na região e fazendo com que se instalasse no planalto 
uma burguesia comercial ligada ao açúcar e que participou ativamente do processo da Independência (MARTINS, 1998).

O reflexo desse crescimento econômico inicial, na formação espacial paulistana, resultou na expansão para além do núcleo histórico no sentido oeste, transpondo o Vale do Anhangabaú. Começou, então, a farta distribuição das terras do rossio a um conjunto de beneficiados.

O processo de apropriação das terras devolutas no Brasil e em particular em São Paulo foi historicamente excludente, de acordo com a relação de poder, de apadrinhamento, amizades e favores. No Pari, podese observar que esse processo também aconteceu.

A realização da propriedade de terras em São Paulo se formou assim que o mercado de terras foi impulsionado, a partir da metade do século XIX, quando ocorreram as grandes transformações relacionadas à expansão cafeeira. Até 1890, a cidade de São Paulo era circundada por um cinturão de chácaras para fins agrícolas principalmente, além de guardar importante função residencial para as famílias de classes abastadas (LANGUENBUCH, 1971).

\begin{abstract}
Em são Paulo, os fazendeiros eram duros aventureiros. Invadiam terras, subjugavam ou destruíam pessoas, esmagavam obstáculos e colhiam avidamente os frutos dessa manifestação de pioneirismo, que combinavam audácia, aventura e espírito empreendedor com móveis do capitalismo comercial, presentes no processo através das relações com as companhias que operavam com a venda de terras, com o financiamento da produção do café, etc. (FERNANDES, 2001: 148)
\end{abstract}

O crescimento da cidade se deu pela ocupação de terras. A maioria eram terras devolutas pertencentes ao Estado, e para se apropriar era necessário legalizá-las (Mapa 22). A maior parte foi legitimada no município paulistano por determinação de lei municipal. Para pedir a legitimação da terra pleiteada, solicitava-a por meio de um requerimento à Câmara, no qual se justificava o pedido e se especificava o local requerido.

Outra maneira, ainda, de legalizar as terras foi por comprovação de posse. Por meio da conferência de posse por um fiscal da Câmara, a 
terra era liberada para seu registro em cartório. É importante relatar que - cartório é uma invenção portuguesa, e que em outros países a efetivação da propriedade é executada por órgãos municipais, que não cobram taxas, ou cobram taxas condizentes com a situação municipal e a condição econômica do futuro proprietário. Esse dado pode parecer secundário, mas não o é, pois, sem fiscalização efetiva e regular pelo poder público e sem a gratuidade ou uma taxa simbólica para validar as terras, o mercado de terra foi sempre um negócio entre particulares, com visão usurária e nunca social.

Os limites sobre os quais poderiam ser efetuadas as transações de terras eram definidos pela administração municipal, e eram denominados de rossio. No caso de São Paulo eram determinados por um círculo em quilômetros que tinha como centro a Praça da Sé. Esse círculo ia se modificando à medida que houvesse demanda de pedidos.

Mapa 22 - Os limites para expansão da legalização de terras no Município de São Paulo

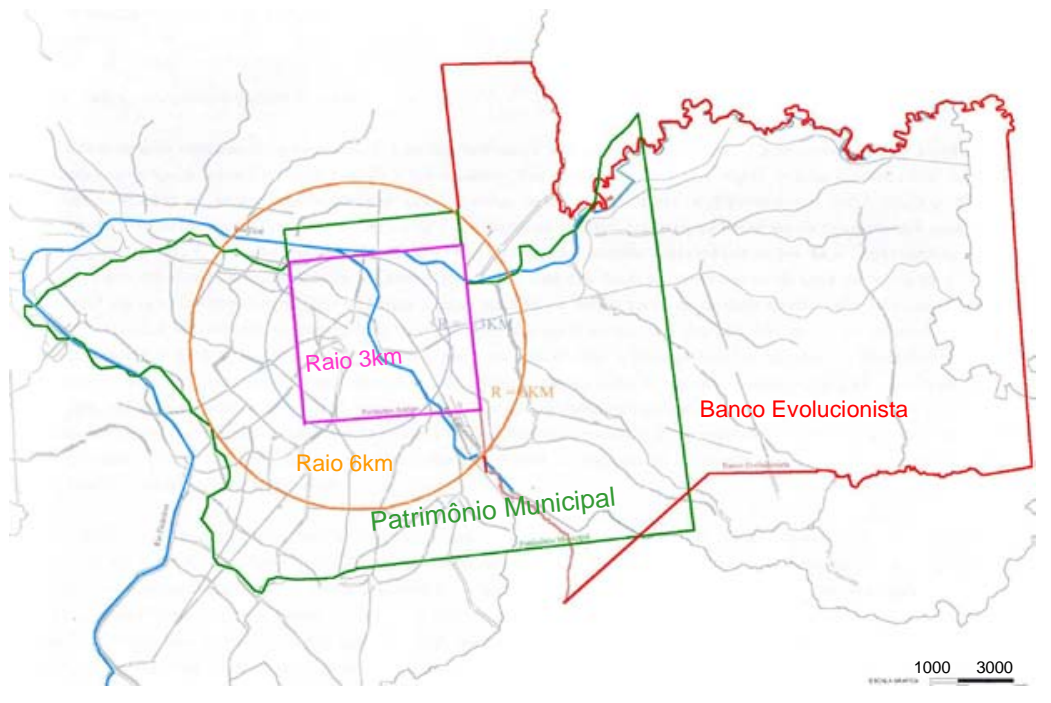

Planta 1897 - Base Geolog - Fonte: MÔNACO (2004:58)

A lei de terras estabeleceu um prazo de cem (100) anos para efetuar as legitimações, e nesse período a ocupação do território paulista 
se deu pela criação de títulos de terras de acordo com a relação de poder, de apadrinhamento, de amizades e favores. Ou até para aliviar a consciência de alguns senhores que conseguiam títulos para seus exescravos (bem longe de suas terras e do centro, obviamente).

A propriedade privada de terra ou a posse de terra no Brasil se consolidou por meio de três (3) regimes a partir do século XVI:

Regime de sesmaria - até $1822^{2}$;

Regime de posse de terras devolutas - 1822 a $1850^{3}$;

Lei de Terras a partir de $1850^{4}$ (CASTILHO, 1993:45).

Com a Proclamação da República, o Governo Provisório criou o sistema de propriedades baseado no "Registro Torrens", o qual estabelecia a forma de registro das terras brasileiras, permitindo mais uma vez a apropriação de terras de posseiros e do patrimônio público.

Com o Encilhamento ${ }^{5}$ (1889-1891), São Paulo teve a criação de 15 bancos e muitas empresas de construção civil, dando início a uma cultura de apropriação de terras e grande especulação com terrenos urbanos (BOTELHO, 2005), que permanece até os dias de hoje.

A criação de títulos e o parcelamento de terras não poderiam ser efetuados sem um intermediário, em geral um advogado; e sem uma empresa que a urbanizasse, ou seja, convertesse a gleba em partes alienáveis. Portanto, a presença do empresário sempre foi de grande importância na legalização das terras da capital, já que a diversificação de seus negócios passava por especular com terrenos, além do comércio de materiais de construção, serrarias, olarias. Eles também exerciam atividades como fazendeiros, deputados ou tinham algum cargo público.

\footnotetext{
${ }^{2}$ Sesmarias eram lotes incultos ou abandonados que os reis de Portugal cediam a sesmeiros que se dispusessem a cultivá-los.

${ }^{3}$ O apossamento de terras era efetuado por latifundiários e pequenos ocupantes, que as consideravam propriedades particulares, diante da ausência do estado na regulamentação da propriedade.

${ }^{4}$ A Lei de Terras diz no seu artigo primeiro: “Ficam proibidas as aquisições de terras devolutas que não seja pela compra".

"A lei de terras se constituiu no estatuto fundamental do disciplinamento da propriedade da terra no Brasil, porque a partir daí é que se estruturariam as bases através do qual o Estado conferiria legitimidade à propriedade da terra, e tentaria objetivar a separação entre as esferas do público e do privado." (SMITH, R., 1989:360).

${ }^{5}$ Encilhamento: O Ministro da Fazenda Rui Barbosa, do Governo de Deodoro da Fonseca, estabeleceu uma política monetária baseado no sistema bancário norte-americano, que se fundamentava na livre emissão de créditos monetários. Para estimular a industrialização e o desenvolvimento de novos negócios, os bancos passariam a liberar empréstimos às pessoas, sem mesmo saber das reais condições de pagamento das mesmas. Foi o primeiro "pacote" econômico da história brasileira.
} 
O acesso à terra foi produzido por um mercado fundiário marcado por profunda especulação e que permitiu que o patrimônio público fosse transformado em um estoque privado das terras por onde a cidade podia estender-se, de forma que o controle desse processo de expansão acabava por concentrar-se muito mais no domínio privado que no propriamente público (BRITO, 2000).

Não há clareza sobre como muitas terras foram legalizadas no município de São Paulo. Nota-se que as grandes empresas urbanizadoras, bancos e comerciantes de peso conseguiam legalizar as terras que denominavam como "suas", por meio do processo acima relatado. Em lugares menos valorizados, pressupõe-se que a legalização da posse tenha sido feita pelos próprios posseiros que aí estavam havia gerações ${ }^{6}$.

Esse processo de apropriação de terras conjugada ao de concentração da propriedade da terra teve nos empresários do setor imobiliário Victor Nothmann, Joaquim Eugênio de Lima, os Paes de Barros, Antônio Proost Rodovalho um papel destacado (BOTELHO, 2005: 127).

A cidade de São Paulo, localizada no planalto, era cercada pelos rios Pinheiros e Tietê, tendo o rio Tamanduateí como divisor das áreas leste-oeste. Na década de 1880, com o processo de implementação da propriedade privada da terra e com o florescimento das atividades provenientes do café, a cidade expandiu seu número de trabalhadores e sua demanda por habitação. A chegada da ferrovia e o grande aumento de atividades econômicas em função do café propiciou à cidade um ritmo de crescimento sem precedentes.

Em 1867, quando foi inaugurada, a Estrada de Ferro São Paulo Railway veio acentuar ainda mais a bipartição do espaço disponível para a expansão de São Paulo. Implantada no vale do Tamanduateí, a ferrovia aumentou a barreira representada não só pelo rio, mas também por sua ampla várzea inundável (VILLAÇA, 1998: 116).

Com o desenvolvimento da cultura cafeeira, que desencadeou diversas outras atividades econômicas na cidade, e o arranque da industrialização, teve início a imigração. A Lei de Terras, também, foi

\footnotetext{
${ }^{6}$ Essa hipótese é aventada na pesquisa do Pari.
} 
concebida como uma forma de evitar o acesso à propriedade por parte dos recém-chegados imigrantes. Ela estabelecia, por exemplo, que as terras públicas deveriam ser vendidas por um preço suficientemente elevado para afastar posseiros e imigrantes pobres. E os estrangeiros que tivessem passagens financiadas para vir ao Brasil ficavam proibidos de adquirir terras, antes de três anos após sua chegada.

A imigração de trabalhadores livres para a lavoura do café substituiu a utilização da mão-de-obra escrava. Com o fim da escravidão, a mudança na economia aumentou o fluxo de rendimento dos trabalhadores e ampliou as margens de seus gastos. A contínua chegada de imigrantes fez a cidade necessitar de um número muito maior de habitações para atender à demanda.

Os imigrantes que se dirigiam à cidade eram, alguns, trabalhadores especializados, como artesãos ou operários da indústria que estava nascendo. Muitos se instalaram no lado leste da cidade, começando aí uma demarcação nítida entre trabalhadores e classe média e alta. A vinda de um número muito grande de imigrantes alterou a vida da cidade em sua forma e conteúdo, como bem lembra Florestan Fernandes:

O imigrante representa mais que uma ruptura com a tradição senhorial e com a dominação patrimonialista, apesar das acomodações que o levaram a compartilhar, de modos mais ou menos profundos, conforme as variações da situação de contato, interesses, valores e ideologias das elites nativas do poder. O imigrante introduziu no Brasil maneiras de ser, de pensar e de agir em que o "cálculo econômico" e a "mentalidade racional com relação a fins" acabaram alcançando, pela primeira vez em nosso país, a consistência estrutural e funcional requerida pelo padrão capitalista de organização da personalidade, da economia e da sociedade (FERNANDES, 2006: 169).

Com o crescimento vertiginoso da cidade, a questão da habitação tornou-se objeto da urbanização paulistana. A habitação no capitalismo é considerada uma mercadoria como outra qualquer, entretanto esta é uma mercadoria que não existe sem a outra, o solo. A aquisição da terra é 
uma condição anterior à edificação de habitações. Portanto, é uma mercadoria com um atributo especial.

Diante dessa nova situação, no fim do século XIX já existia um mercado imobiliário considerável, constituído de um lado por habitações para a alta classe e de outro por casas operárias, habitações coletivas, quartos para aluguel e loteamentos de antigas chácaras.

Somente as classes altas e médias chegam a participar
efetivamente das vantagens proporcionadas pelo
desenvolvimento capitalista. Essa participação é em si mesma,
um privilégio e só se pode manter na medida em que
privilégios, vitais para as situações de classe alta e média, são
intocáveis (idem: 311 ).

A segregação espacial da cidade foi, já na sua origem, produzida na cidade de forma a depositar a classe trabalhadora nas várzeas alagadiças, sujeitas às enchentes e, portanto, insalubres, e ao longo da ferrovia. Fez-se, então, um corte bastante acentuado entre os rios Tietê e o Tamanduateí: a Zona Leste para os mais pobres e a Zona Oeste e as áreas mais altas para os patrões e funcionários públicos (classe média).

Os espaços da cidade são política e socialmente diferenciados de acordo com os grupos sociais que nela habitam, de tal modo a definir "territórios" distintos. Grosso modo, os pobres amontoam-se em bairros precários e os ricos espalham-se em espaços monumentais (KOWARICK, 1994: 97).

O avanço industrial em São Paulo após 1930 acelerou a urbanização, fazendo diminuir a cada dia a zona rural. A tendência à metropolização se firmou em 1940 e já em 1950 a metrópole estava consolidada. No entanto, o problema de oferta de habitações para a classe trabalhadora não foi solucionado; ao contrário, se agravou mais, na medida em que a metrópole se tornou mais populosa.

Era um círculo vicioso: o poder público não investia em habitações populares para não desfazer o mercado privado, que por sua vez construía habitações para a população de baixa renda de péssima qualidade e em quantidade insuficiente ou a preços que impossibilitavam a compra. A preocupação com a precariedade das condições habitacionais 
resultava quase sempre em medidas favoráveis ao setor imobiliário rentista, como a isenção de impostos para a construção de moradias, adotada em todos os níveis de governo. Essas iniciativas só aumentavam os ganhos dos proprietários, pois, em um mercado de oferta escassa, regulado pela oferta e a procura, o subsídio sob forma de isenção fiscal acabava não sendo transferido para o inquilino (BONDUKI, 2000).

A retenção de imóveis na expectativa de sua valorização, a disposição desses imóveis a preços acima dos praticados no mercado ou ainda a construção com a finalidade de alugar era uma prática evidente desse início de século XX. Assim, a especulação imobiliária era fortalecida, aproveitando-se da enorme demanda por moradias, e os bairros operários foram se estruturando de maneira fragmentada. Essa evolução, que resultou na ocupação caótica da cidade, não foi fruto do acaso e da falta de planejamento urbano, e sim a forma de implantação de uma metrópole cuja construção se deu de acordo com a lógica do capital imobiliário conjugado ao capital industrial e mais tarde ao capital financeiro. Somando-se a isso, o poder público ajudou de forma velada a concretizar a situação, por omissão ou por desconsiderar o mercado de terras informal, que já era bastante atuante na época (PACCA, 2004).

Foi neste contexto que em 1942, o governo interferiu no mercado de locação, congelando os aluguéis por meio da lei do inquilinato. A medida adotada, à primeira vista, pareceu ser um golpe contra os proprietários de casa de aluguel. Mas a legislação, ao mesmo tempo em que parecia querer proteger os trabalhadores contra o abuso dos proprietários, também provocava distorções, afetando o mercado de construção de habitações populares e permitindo que a lei fosse burlada com frequência.

\footnotetext{
A lei do inquilinato não foi nenhuma medida "social", nem de proteção aos interesses dos inquilinos como alardeava o Estado Novo, mas sim, uma intervenção do Estado que contribuía para destruir o modelo da casa alugada e implantar o da casa própria (VILLAÇA, 1986:51).
}

Em 1963, foram apresentadas por Jango reformas de base através das quais propunham-se transformações legais substantivas no sentido de combater a especulação imobiliária e equacionar a questão urbana e 
habitacional. Esse foi um momento de muita discussão sobre o significado da propriedade privada da terra e imobiliária. Mas as reformas não se concretizaram e a metrópole tomou outro rumo sem discutir a dominação da propriedade privada da terra e a interferência desta no cotidiano da vida urbana, como um processo hegemônico.

Em São Paulo, a atitude do Estado e da classe dominante foi muito eficiente em promover a segregação e a exclusão espacial. A cidade era considerada só o centro histórico de hoje, e na área ocupada pela classe mais abastada, os dogmas do urbanismo eram implantados, submetendose às regras e a preceitos da higiene e da estética. Os trabalhadores ocupavam as áreas que não obedeciam a essas regras, lugares em condições de habitabilidade difíceis e cada vez mais na periferia, ou seja, distantes do centro e dos ricos. Os grandes negócios imobiliários possibilitaram que na área periférica da cidade, antes de ela tornar-se metrópole, fossem criados espaços vazios, não regulados pela legislação, que com certeza seriam rentáveis num futuro mais próximo ou mais distante, dependendo do ritmo de investimentos dos melhoramentos urbanos providenciados pelo poder público. Esse processo de desenvolvimento da metrópole foi reproduzido no desenvolvimento do seu crescimento em todas as direções.

No período de 1964 a 1985, a metrópole paulistana foi marcada por grandes obras viárias, que privilegiavam os automóveis e acentuavam seu crescimento desordenado, grande verticalização e expansão da periferia. A metropolização de São Paulo concretizou-se assim, com uma estrutura rádio-concêntrica, constituindo um organismo político administrativo altamente centralizado. O arranjo espacial da metrópole, apoiado na infraestrutura viária, na rede de transporte, além de oferecer eixos à expansão metropolitana, provocou a estruturação de polos cristalizadores do desenvolvimento em escala local.

A produção do espaço numa metrópole se modifica em consonância com a implantação da infraestrutura viária e de transportes de massa e, assim, sua estrutura passa por um processo de reestruturação que não se dá de forma homogênea. Há bairros onde a dinâmica urbana é bem menor do que em outros. O urbano perpetuamente em movimento está diretamente ligado aos interesses do mercado imobiliário e do Estado, que por sua vez acatam exigências da 
classe dominante. A metrópole de São Paulo é o próprio reflexo da sua forma de ocupação, que mostra nitidamente esse processo, pois a concentração da propriedade privada da terra nas mãos do poder dominante revela a separação entre ricos e pobres, os quais são empilhados em áreas de pouco interesse imobiliário.

Compreender o processo de produção da cidade como um processo calcado no valor denuncia a dualidade do modelo implantado de cidade legal/ilegal, centro/periferia, verticalização/autoconstrução. No entanto, a integração desse espaço dual se faz com partes da cidade que possuem uma dinâmica própria e não se inserem nessa dualidade, como o Pari, que não é centro nem periferia, é legal e ilegal, não é verticalizado e nem apresenta autoconstrução.

\section{I - A renda da terra}

A propriedade privada fundiária ou imobiliária é uma mercadoria viabilizada em função do espaço, e como produto social no espaço urbano cria seu valor de acordo com sua localização (VILLAÇA, 1985:9). A aquisição de propriedades imobiliárias é um meio de acumular riqueza na sociedade moderna capitalista e o espaço urbano, como produto social, não pode ser separado das forças econômicas, políticas e culturais. O espaço construído é um produto social, é um momento da reprodução da sociedade, uma síntese da soma de trabalhos privados.

Portanto, ao partir do pressuposto que a existência da concentração de imóveis sob o domínio de poucos proprietários desempenha no capitalismo a função pela qual a renda da terra se realiza (HARVEY, 1990), é necessário discorrer sobre a compreensão da renda da terra urbana. É posto que a acumulação da propriedade privada imobiliária seja o ponto chave tanto para auferir a renda da terra, como para excluir muitos de seu acesso. O fenômeno da concentração de propriedades imobiliárias é uma forma de assegurar valorização, como foi afirmado pelos proprietários pesquisados, já que os imóveis, numa metrópole como São Paulo, mesmo em tempo de estagnação econômica e de grande inflação, não diminuem seus valores. 
A terra e o homem constituem "as duas fontes originais de toda a natureza" (MARX, 1985). Em estado virgem, a terra é o objeto sobre o qual versa o trabalho humano, a "condição original" de toda produção e a depositária de uma variedade aparentemente infinita de valores de usos potenciais que a natureza presenteia ao homem.

Marx, no livro: “Capítulo VI inédito de O Capital”, diz:

O capital só se torna verdadeiramente capital quando se torna "valor em processo"; só se, no interior do processo de produção, o toque mágico do trabalho humano o transformar de grandeza constante em grandeza variável. (MARX, 1969: 19).

Segundo Marx, o Valor $^{7}$ na sociedade capitalista se distribui em forma de salários, renda, juros, lucro e impostos. As categorias juros, renda e lucro estão mesclados e é difícil a identificação de cada uma delas em separado. Os juros, a renda e o lucro

\footnotetext{
nada mais são que nomes diferentes para exprimir diferentes partes da mais valia ${ }^{8}$ de um mercadoria ou do trabalho não remunerado que nela se materializa, e todos provêm por igual desta e só desta fonte (MARX, 1974:92).
}

A fonte a que Marx se refere, é a relação entre capital e solo, é o processo de valorização do capital que permite ao proprietário da terra obter a mais-valia. A valorização do espaço se dá porque o espaço na sociedade capitalista é uma mercadoria. Uma mercadoria com características especiais, pois é condição e meio de produção. O solo e as benfeitorias são mercadorias que nenhum indivíduo pode dispensar. Não se pode existir sem ocupar espaço; não se pode trabalhar sem ocupar um lugar e fazer uso de objetos materiais aí localizados; e não se pode viver sem moradia de alguma espécie.

$$
\begin{aligned}
& \text { Os processos de valorização do espaço passam, } \\
& \text { necessariamente, pela mercantilização do próprio espaço, }
\end{aligned}
$$

\footnotetext{
7 Marx definiu o valor pelo tempo de trabalho socialmente necessário à produção de uma mercadoria (MARX, 1975:617).

${ }^{8}$ Grifo da autora.
} 
concretamente pela mercantilização dos lugares (SEABRA, 1988: 101).

A renda é uma parte dessa valorização (da mais-valia) recebida como resultado de atividade produtiva individual ou coletiva, devido à inelasticidade (escassez e necessidade) do solo. A renda é a parte do valor de troca que se destina ao proprietário do solo (HARVEY, 1980). A valorização, como concorda Villaça, no texto, "A Terra como Capital",

a renda é sempre uma parcela da mais valia criada, por alguma atividade produtiva exercida sobre a terra (VI LLAÇA, 1985: 8).

A renda é o pagamento feito aos proprietários pelo direito de possuir e de usar a terra. A terra neste sentido tem um valor de uso e um valor de troca. O pagamento feito aos proprietários seria impossível sem a troca geral de mercadorias, sem a plena monetarização da economia e todos os acréscimos legais e jurídicos da propriedade privada da terra.

Marx construiu no volume III de O Capital, uma teoria sobre a renda, e estabeleceu três formas de renda:

A renda de monopólio - é a renda baseada no poder monopolista de deter privadamente certas porções do planeta. Os proprietários que dispõem de terra com alguma qualidade ou situação especial relacionada com um tipo de atividade estão em posição privilegiada de cobrar renda de monopólio aos que desejam usar essa terra. Os lugares elegantes e de prestígio criam todo tipo de possibilidade de cobrar rendas de monopólio a outros grupos da burguesia. A renda de monopólio depende da capacidade para realizar um preço de monopólio para o produto.

A renda diferencial - é a renda criada por características específicas de vantagem. A localização é uma variável peculiar que pode caracterizar uma situação de vantagem (e é renda de monopólio porque é única). A localização é socialmente produzida. Como diz Villaça,

A terra-localização - da qual a terra urbana é a mais óbvia manifestação - enquanto produto humano, tem tanto valor de uso como valor de troca. Tal como qualquer outro, seu valor é 
determinado pelo tempo de trabalho socialmente necessário para produzi-la (VILLAÇA, 1985: 10).

Dois imóveis iguais (mesma área, estrutura física, declividade) localizados em pontos diferentes de uma cidade quase sempre possuem preços diferentes. Os agentes imobiliários estabelecem preços diferenciados por metro quadrado para cada área da cidade e criam um mapa de valores urbanos específicos.

A localização privilegiada no espaço urbano é praticamente irreprodutível. As áreas com características exclusivas são criadas para determinados consumidores, os quais estão dispostos a pagar uma renda de monopólio para poderem aí se localizar, seja em função do status que tal localização traz, seja em função de um acesso privilegiado (HARVEY, 1980). A faculdade do solo em conseguir vantagens e amortizar custos depende de sua rigidez de localização em relação a todos os custos e benefícios externos que estão sendo gerados pela atividade social no sistema urbano.

Portanto, a propriedade "natural" de não-reprodutibilidade do solo contribui para a afirmação de um grupo social como detentor do monopólio fundiário A escassez é socialmente determinada. As relações sociais que sustentam a propriedade privada da terra transformam o solo em uma raridade, em dado momento, e por certo tempo, para o capital privado.

A renda absoluta - como a terra é um bem finito, a propriedade privada da terra proporciona uma renda absoluta. A renda absoluta depende das condições de oferta e demanda. A capacidade para apropriar-se da renda é fruto de um conflito potencial provocado pela necessidade social da propriedade privada criada pelo capitalismo e da acumulação desenfreada. A renda diferencial: fertilidade do solo (rural) ou o potencial construtivo no solo (urbano) é outra vantagem a qual produz renda (e é renda absoluta porque é finita).

A renda é determinada em relação a todas as esferas de produção, em todas as localizações, com as expectativas futuras também incorporadas no cálculo (HARVEY, 1980).

Marx se pergunta como o proprietário fundiário, sem dispor de capitais, sem investir, pode captar uma parte da mais-valia. Resposta: o caráter formal da propriedade (o direito de propriedade) permite-Ihe isso. 
Ele extrai da terra, sem mesmo explorá-la, sem tocá-la, a renda dita absoluta e uma grande parte das rendas ditas diferenciais, vindo da diversidade das terras, de sua fertilidade variável, da localização mais ou menos favorável, dos trabalhos de infraestrutura efetuados e dos capitais investidos socialmente (LEFÈBVRE, 1999).

O monopólio da propriedade privada territorial, além de ser uma premissa histórica, é também uma base constante no modo de produção capitalista. A implicação é que a apropriação da renda e a existência de propriedade privada de terras são condições socialmente necessárias para a perpetuação do capitalismo.

O processo de circulação do capital reproduz uma organização espacial cheia de contradições e estreitamente ligada ao funcionamento dos mercados de terra, que por sua vez apoia-se na capacidade para apropriar-se da renda. A circulação do capital a juros dos mercados de terras organiza o uso da terra com o da produção de mais-valia da mesma forma que ajuda a recompor as atribuições da força de trabalho e a igualar a taxa de lucro através das diferentes linhas de produção.

A renda da terra capitalizada como juros sobre algum capital imaginário constitui o valor da terra. O que se compra e se vende não é a terra, mas o direito à renda que produz. O dinheiro que se desembolsa equivale a uma inversão que produz juros. O comprador adquire um direito sobre as entradas futuras previstas, um dinheiro sobre os frutos futuros do trabalho.

As trocas previstas nas rendas futuras ligadas aos investimentos do Capital e ao trabalho afetam igualmente os preços da terra e da propriedade. O elemento especulativo sempre estará presente no comércio de terras.

No caso da cidade, onde as construções crescem rapidamente, diz Marx:

o lucro que se obtém ao construir é sumamente pequeno, o lucro principal surge do crescimento das rendas, de tal forma que a renda da terra é o objeto real dos especuladores da construção e não a moradia (apud HARVEY, 1990).

Os proprietários de terrenos desempenham o papel de criar condições que Ihes permitam apropriar-se de rendas futuras. 
Para Lipietz (1974: 37 e 39), existiria uma hierarquia de usos do solo determinada pelo valor de uso da centralidade (ou qualquer outra particularidade do lugar) e pela capacidade dos usuários de pagar, sendo que o mecanismo da renda da terra estabilizaria e reproduziria essa hierarquia em sua coincidência com uma Divisão Social e Econômica do Espaço (apud BOTELHO, 2005:21).

A união do capitalista com o proprietário é uma forma de a renda fundiária se incorporar na acumulação capitalista. Outra maneira de incorporar a renda fundiária à circulação capitalista se dá através do mercado financeiro, com a transformação da propriedade da terra em um título comercializável e alienável através de empréstimos e hipotecas. A terra passa a ser um bem puramente financeiro. Vira capital fictício, pois o proprietário tem direito sobre utilidades futuras sobre o uso da terra, um direito à mais-valia gerada por um trabalho futuro.

Ou seja, a propriedade fundiária e a renda que seu proprietário tem o direito de extrair da mais-valia global tornam-se elementos constituintes da acumulação capitalista, seja através da especulação e da incorporação imobiliária, seja através da circulação da renda capitalizada no mercado financeiro (hipotecas e títulos imobiliários) (BOTELHO, 2005).

A renda fundiária e a propriedade contribuem para a contínua reprodução da classe dos que não possuem os meios de subsistência e que têm de vender sua força de trabalho para reproduzir-se, sendo também uma das condições para a reprodução das relações de produção capitalista. O capital financeiro tornou-se um elemento muito presente nas estratégias de reprodução do capital a partir da década de 1970 (CHESNAIS, 1999).

Portanto, da análise feita acima podemos tirar três conclusões:

I - O preço da terra não pode existir sem o poder de monopólio da propriedade privada da terra e a capacidade de apropriação das rendas. A renda e a propriedade privada da terra são socialmente necessárias para permanência do capitalismo. E o preço da terra, como uma expressão do valor, diz Villaça,

é um preço composto ou complexo, determinado pela combinação de três componentes: 
1. O componente oriundo da renda absoluta (renda capitalizada).

2. O componente oriundo do valor da terra (localização).

3. o componente que exprime um preço de monopólio (renda de monopólio) (VILLAÇA, 1985: 13).

II - O preço da terra capta simultaneamente o caráter temporal da acumulação (registrada por movimentos na taxa de juros) e o caráter específico dos valores de usos materiais distribuídos no espaço e, portanto, une as considerações temporais e espaciais dentro de uma só estrutura definida pela lei do valor.

III - A circulação em títulos da terra do capital a juros desempenha um papel análogo ao do capital fictício. Indica o caminho a se tomar para uma acumulação futura e atua como um catalisador que reorganiza a configuração espacial da acumulação de acordo com os imperativos fundamentais da acumulação.

Para melhor compreender como se realiza a renda no espaço no distrito do Pari, ou se ela se realiza, realizamos uma pesquisa que pretende interpretar a realidade desse fragmento da cidade, e tentar vislumbrar se há renda da terra urbana. Como trabalhar essa relação da teoria com a prática?

A classe proprietária dita a conduta e a moralidade da sociedade. Não enriquece do trabalho, desfruta rendas, representadas por aluguéis, juros, dividendos e prestações. A fortuna já vem pronta de uma geração a outra. Bastará, apenas, se necessário, convertê-la em bens de desfrute seguro, nada mais. A renda assegura vida estável, luxuosa e, sobretudo, ociosa. (Raymundo Faoro, 1971, apud Pochmann, 2009:5)

É um desafio entender e encontrar um meio de demonstrar que há renda da terra urbana. A renda é um meio pelo qual o capitalismo pode se expandir e criar espaços globalizados ${ }^{9}$ - espaços preferenciais de

\footnotetext{
${ }^{9}$ Entende-se por globalização o conceito definido pelo professor Csaba: "No caso da globalização, o termo é usado a torto e a direita, para explicar fenômenos do capitalismo contemporâneo, para justificar medidas econômicas de governos nacionais e até políticas urbanas de governos locais. O que é geral é que na maioria dos casos a palavra 'globalização' vem com uma conotação de inexorável,
} 
atuação do mercado imobiliário e de intervenções públicas - que, por sua vez, também podem criar espaços com escassez de dinamismo - fruto da contradição do mesmo fenômeno - , para os quais, no presente trabalho, adotamos o nome de áreas estagnadas ${ }^{10}$.

A ideia de "cidade global" está fortemente ligada à noção de globalização da economia, da reestruturação econômica iniciada na década de 1970 (HARVEY, 1993). Contudo, por trás da ideologia de "cidade global", o que realmente ocorre é a manipulação do imaginário social, provocando uma visão de que é impossível outra opção, de que não há outro caminho nem outra saída. Esse movimento foi descrito por Harvey como o movimento pelo qual o capital intervém no espaço urbano, ao buscar novas formas de obtenção de lucro, intervenção caracterizada por um maciço investimento territorial, que provoca forte expansão urbana e inaugura nova fase na economia. Mas, se dentro da "cidade global" acontecem investimentos, as áreas sem investimentos prosseguem por quais caminhos? Ou estacionam? Aliás, sempre há uma evolução. Maior ou menor. Mas essas áreas não acompanham o dinamismo da "cidade global". Elas possuem um ritmo mais lento, inerente à sua dinâmica no espaço urbano.

O estudo do Pari revela essa outra face da globalização. A preocupação de muitos estudos é destacar o aspecto global da cidade paulistana, ou aquilo que é diferente ou importante para a classe dominante, as áreas da elite, por apresentar o universo de atuação dessa classe. Também se manifesta uma apreensão com as áreas dos mais pobres, como as favelas, que incomodam a mesma classe. Essas análises são procedentes para a compreensão da cidade. Porém, a maioria, o comum, o ordinário é ignorado, essas áreas são desprezadas pela mídia, pelo poder ou pela academia, e passam dissimuladas nos estudos sobre a cidade. São os lugares da metrópole onde vive e habita a maioria da população. Tanto a parcela mais rica está inserida na cidade, como o Pari também. A totalidade da cidade é a expressão da soma das partes que se

acompanhante inevitável do rolo compressor da modernidade" (Csaba, Globalização ou crise global? FAUUSP, 2000).

10 Entende-se por estagnação, resumidamente, o processo por meio do qual algumas áreas produzem um movimento mais lento do que outras, ou até permanecem imobilizadas na evolução da produção do espaço urbano. 
conflitam, disputam e se movimentam no processo de desenvolvimento urbano.

As histórias dos bairros da cidade de São Paulo pouco esclarecem sobre os bairros e loteamentos populares, enquanto há abundantes estudos sobre os de alta renda (VILLAÇA, 1998: 117).

Já foi demonstrada, no presente trabalho, a localização privilegiada do distrito do Pari. Encontra-se ao lado do centro histórico da cidade, limita-se com a Marginal Tietê, de acesso fundamental para muitas rodovias importantes que levam ao interior do Estado e ao norte do país. É ladeado pelo rio Tamanduateí, cujas vias marginais integram-se com os municípios do $A B C D$ paulista. O bairro está situado próximo à linha nortesul do metrô e da linha férrea da CPTM, que liga o oeste ao leste da cidade. Essa localização privilegia o acesso a todas as direções da cidade com facilidade. E localização é um elemento de peso para valorizar a terra urbana. Como conceituou Villaça: a localização é um valor de uso produzido, não é um dom gratuito da natureza (VILLAÇA, 1985: 7).

Todavia, mesmo com essa posição singular, não há interesse do mercado imobiliário de investir e dinamizar a área. Essa afirmação não é um julgamento de valor, é uma constatação. A falta de interesse por parte dos investidores urbanos (empresas imobiliárias ou construtoras de infraestrutura) tem como razão principal o fato de o bairro não estar inserido no vetor tradicional de atuação da classe dominante, ou seja, não pertence ao quadrante sudoeste da cidade. $E$ também porque, historicamente, o Pari é parte integrante das áreas destinadas à população trabalhadora do município - logo, excluído dos grandes empreendimentos. Apesar disso, o desprezo do mercado não traz problemas à vida dos moradores, e a própria negligência do Estado abre espaço, no bairro, a um convívio sem grandes disputas entre moradores, frequentadores, trabalhadores e proprietários.

O monopólio da propriedade privada territorial e imobiliária, além de ser uma premissa histórica, está na base de todas as formas que pode tomar o modo de produção capitalista. A apropriação da renda e a existência de propriedade privada de terras são condições socialmente necessárias para a perpetuação do capitalismo. É necessário estabelecer 
a base dessa necessidade social, pois o capital integra a propriedade pelo seu valor de troca, e o uso, o social, não é integrado. A propriedade da terra e de imóveis também desempenha um papel para obrigar a fixar o capital na terra, isto é um dos efeitos das apropriações da renda sobre a acumulação.

A análise dos registros de compra e venda, antes de 1850, demonstra que 37\% das transações foram efetuadas na Freguesia da Sé, ou seja, a área na qual o distrito do Pari fazia parte. Esse índice é maior ainda no Brás (44\%) (CASTILHO, R., 1993:64). Cerca de 20\% das propriedades analisadas por Castilho foram legalizadas por meio de herança ou transmissão de posse. Mas, também, houve um grande processo de efetivação de registro de imóveis em áreas devolutas, ou seja, sem compra e venda. Esse processo não foi exclusivo da área central, ocorreu indiscriminadamente por toda a metrópole.

A pesquisa sobre a propriedade imobiliária do distrito do Pari lança uma luz sobre o que ocorre no universo da metrópole paulistana. Tentamos, aqui, analisar uma parte para compreender o todo. A escolha desse campo empírico se deu pela dificuldade de abarcar toda a cidade. Procuramos fazer uma reflexão teórica e empírica por acreditarmos que a concentração da propriedade é um fato inerente à especulação imobiliária, que por sua vez é resultado necessário das formas pelas quais se realiza a acumulação do capital na produção imobiliária.

\section{III - A propriedade imobiliária}

$\mathrm{Na}$ pesquisa inicial do presente trabalho agregamos todas as propriedades imobiliárias, que somam 6.345 imóveis (SF/PMSP, 2006) distribuídos em 130 quadras, com uma população residente de 14.824 pessoas (IBGE, 2000) ${ }^{11}$, ocupando 4.408 domicílios, dos quais 2.082 são próprios e 2.155 alugados - quase 50\% - e 171 são cedidos (IBGE/ SEMPLA 2000). De 6.345 imóveis tem-se 4.408 domicílios (70\%). Ou

\footnotetext{
${ }^{11}$ Não há censo demográfico mais recente, apenas estimativa. Então, optamos por um número concreto. A estimativa para 2006 é de 15.417 habitantes (SEMPLA/DIPRO).
} 
seja, 1.037 imóveis são: não residenciais, terrenos vazios, estacionamentos, empresas (comércio, serviço, indústria) e instituições.

No Pari, existem duas favelas, 162 cortiços (tabela 10) e 167 imóveis vagos perceptíveis (contados a partir de pesquisa efetuada em campo). O mercado informal de aluguel é frequentemente explorado, no Pari, por proprietários que muitas vezes compram imóvel de espólio em litígio a preço irrisório e, por meio de um "gato", exploram os mais carentes, alugando por cômodo, isto é, transformando-o em cortiço. Mesmo fazendo uma pesquisa rua a rua e conversando com moradores para identificar os cortiços, é difícil ter certeza do número correto deles, porque muitas vezes não é possível distinguir um cortiço de uma pensão ou mesmo de uma habitação deteriorada, com vários moradores.

As propriedades foram classificadas em: propriedades "Pessoa Física" e propriedades "Pessoa J urídica".

As propriedades Pessoa Física foram classificadas por nacionalidades, já que há uma grande incidência de descendentes de imigrantes e mesmo de imigrantes recentes. O Pari é um bairro que se formou no início do século XX, local de implantação de algumas antigas indústrias e próximo ao Brás - bairro de grandes indústrias têxteis. Cresceu como o lugar de moradia de grande número de operários.

As propriedades Pessoa Jurídica são: empresas, imobiliárias, institucionais e públicas.

Dos imóveis registrados em nome de Pessoa Física, computamos os proprietários com 2 imóveis ou mais e descartamos os que possuem apenas um. Como a finalidade é analisar a concentração de imóveis, optamos por excluir os proprietários de um imóvel só - mesmo levando em conta que ele possa ter um segundo imóvel em outra área da cidade - por deduzir que esse imóvel seja para uso próprio. Essa foi a forma encontrada para analisar um bairro da cidade, considerando que essa análise possa ser extrapolada para a cidade toda. Pode parecer que computar apenas dois imóveis por proprietário seja pouco para definir como concentração. Contudo, consideramos esse número razoável se se levar em conta que ele é proporcional à pequena área do município, ou seja, um distrito com $2,9 \mathrm{~km}^{2}$. Ademais, se tomássemos como parâmetro 5 ou 6 imóveis, grande parte dos maiores proprietários - os portugueses - seria eliminada, como será demonstrado. 
Antes de enfocar os dados que demonstram a concentração de propriedades no Pari, vale destacar que a metade de seus domicílios é alugada, proporção muito maior que a da média do município, que é de 21\% (IBGE, 2000; SEHAB, 2004). Essa constatação confirma a importância da renda dos proprietários desses imóveis.

1. Os proprietários Pessoa Física com 2 imóveis ou mais foram classificados por nacionalidades:

Portugueses

Italianos

Árabes

Outros $^{12}$

Coreanos $^{13}$

2. As propriedades de Pessoa Jurídica foram assim classificadas:

Imobiliárias

empresas

públicas

Entidades religiosas.

O total de imóveis no Pari é: $\mathbf{6 . 3 4 5}$

1. O número de imóveis em nome de Pessoa Física é: 5.768

2. O total de imóveis em nome de Pessoa Jurídica é: 577

O número de imóveis em nome de Imobiliárias é: 229

O número de imóveis em nome de Empresas é: 207

O número de imóveis em nome de entidade pública é: 85

O número de imóveis em nome de entidades religiosas é: 56

- $\quad$ Propriedades de Pessoa Física

Das Pessoas Físicas, 5.768, foram destacados os proprietários com 2 imóveis ou mais, totalizando 2.140. Além desses proprietários, computamos o número de imóveis por nacionalidades, destacando a titularidade em nome de todos os coreanos, independentemente do número de imóveis de cada um, por serem um grupo de estrangeiros como muita atividade econômica e

\footnotetext{
${ }^{12}$ Dentro destes existem: espanhóis, judeus, chineses e armênios, basicamente.

${ }^{13}$ Os imóveis dos coreanos foram todos computados primeiramente. E depois foram separados os que possuem dois imóveis ou mais, para serem agregados com os restantes proprietários.
} 
acentuada atuação na paisagem urbana do bairro, pela disposição em reformar e modernizar seus imóveis.

Tabela 12 - Quantidade de Imóveis por Proprietários (Pessoa Física) - Distrito do Pari - 2006

\begin{tabular}{|c|c|c|c|c|}
\hline $\begin{array}{l}\text { Imóveis por } \\
\text { proprietário }\end{array}$ & \multicolumn{2}{|c|}{ Imóveis } & \multicolumn{2}{|c|}{ Proprietários } \\
\hline 20 ou mais & 341 & $5,90 \%$ & 13 & $0,30 \%$ \\
\hline 11 a 19 & 208 & $3,60 \%$ & 15 & $0,40 \%$ \\
\hline 6 a 10 & 443 & $7,70 \%$ & 61 & $1,50 \%$ \\
\hline 3 a 5 & 721 & $12,50 \%$ & 200 & $4,80 \%$ \\
\hline 2 & 422 & $7,30 \%$ & 211 & $5,10 \%$ \\
\hline $1^{(1)}$ & 5 & $0,10 \%$ & 5 & $0,10 \%$ \\
\hline Sub Total & 2140 & $37,10 \%$ & 505 & $12,20 \%$ \\
\hline Total & 5768 & $100,00 \%$ & 4133 & $100,00 \%$ \\
\hline
\end{tabular}

Os imóveis do distrito do Pari com titularidade em nome de pessoas físicas somam 5.768 (tabela 13) para uma população residente estimada em 15.417 habitantes (SEMPLA/DIPRO, 2006). Desses imóveis 2.140 (37,1\% do total) (tabela 14) estão concentradas em mãos de 505 titulares (12,2\% dos proprietários), possuidores de grandes glebas ou de duas propriedades, que representam apenas $3, \mathbf{3} \%$ da população residente. É importante frisar que, como a população estimada para 2006 é de 15.417, significa que os proprietários representam 3,3\% da população, sendo que $51 \%$ dos imóveis são alugados. 
Tabela 13 - Quantidade de Imóveis por Proprietários Pessoa Física com 2 Imóveis ou Mais. Distrito do Pari - 2006

\begin{tabular}{|c|c|c|}
\hline $\begin{array}{l}\text { Quantidade } \\
\text { de imóveis }\end{array}$ & $\begin{array}{l}\mathrm{N}^{\circ} \text { de pro- } \\
\text { prietários }\end{array}$ & $\begin{array}{l}\text { Total de } \\
\text { imóveis }\end{array}$ \\
\hline $1^{(1)}$ & 5 & 5 \\
\hline 2 & 211 & 422 \\
\hline 3 & 113 & 339 \\
\hline 4 & 53 & 212 \\
\hline 5 & 34 & 170 \\
\hline 6 & 22 & 132 \\
\hline 7 & 19 & 133 \\
\hline 8 & 8 & 64 \\
\hline 9 & 6 & 54 \\
\hline 10 & 6 & 60 \\
\hline 11 & 5 & 55 \\
\hline 12 & 1 & 12 \\
\hline 13 & 1 & 13 \\
\hline 14 & 4 & 56 \\
\hline 16 & 1 & 16 \\
\hline 18 & 1 & 18 \\
\hline 19 & 2 & 38 \\
\hline 20 & 1 & 20 \\
\hline 21 & 3 & 63 \\
\hline 24 & 1 & 24 \\
\hline 25 & 2 & 50 \\
\hline 26 & 2 & 52 \\
\hline 29 & 2 & 58 \\
\hline 34 & 1 & 34 \\
\hline 40 & 1 & 40 \\
\hline Total & 505 & 2140 \\
\hline
\end{tabular}

A tabela acima informa que 505 pessoas são proprietárias de 2.140 imóveis $(37,1 \%)$. Desses proprietários, 5 possuem apenas 1 imóvel, mas dada suas dimensões - mais de $5.000 \mathrm{~m}^{2}$ - optamos por registrá-los.

211 pessoas possuem 2 imóveis cada $=422$ imóveis $(7,3 \%)$.

200 pessoas possuem de 3 a 5 imóveis $=721$ imóveis $(12,5 \%)$.

61 pessoas possuem de 6 a 10 imóveis $=443$ imóveis $(7,7 \%)$.

15 pessoas possuem de 11 a 19 imóveis $=208$ imóveis $(3,6 \%)$.

E 13 possuem 20 ou mais imóveis cada = 341 imóveis $(5,9 \%)$.

Mostra-se, aqui, a representação do número de proprietários frente à população residente. Isso é uma demonstração simbólica, porque nunca 
pode existir uma propriedade para cada habitante. Assim é mais significativo fazer a comparação entre os proprietários com o número de domicílios, já que pode haver a possibilidade de cada domicílio ter um proprietário. Não é o que acontece, mas faz-se, então uma simulação. O número de domicílios do Pari é de 4.408 .

Total de domicílios do Pari: 4.408 - 100\%

Total de imóveis concentrados $\geq 2: 2.140-48,5 \%$

Proprietários com mais de 2 imóveis: 505 - 11,4\%

Ou seja, no Pari $11,4 \%$ dos proprietários detêm $48,5 \%$ dos imóveis existentes.

De qualquer forma, a comparação feita entre domicílios e população residente sempre resulta numa porcentagem de muitos imóveis para poucos proprietários. A concentração de imóveis no Pari é um fato.

Tabela 14 - Domicílios por Condiçáo de Ocupação Distrito do Pari - 2000

\begin{tabular}{|c|c|c|c|c|}
\hline \multicolumn{5}{|c|}{ Domicílios por condição de ocupação } \\
\hline Total & Próprio & Alugado & Cedido & $\begin{array}{c}\text { Outra } \\
\text { condição }\end{array}$ \\
\hline 4.408 & 2.083 & 2.155 & 148 & 23 \\
\hline $100 \%$ & $47,30 \%$ & $49 \%$ & $3,40 \%$ & $0,06 \%$ \\
\hline
\end{tabular}

O importante é mostrar a evidência da concentração de imóveis nas mãos de poucos e que a população locatária é o dobro da média da cidade. No distrito do Pari há uma situação incomum sobre a média do município e os proprietários encontram aí condição de auferir rendimento. A concentração significa que existem imóveis disponíveis para a população moradora e existe demanda porque há uma incidência grande de imóveis alugados. Se há proprietários que investem em imóveis na área, eles têm uma expectativa de valorização futura e obtêm rendimentos já. 
- Nacionalidades

Das pessoas físicas que possuem mais de 2 imóveis, o número de imóveis por nacionalidade é:

Tabela 15 - Propriedades por Nacionalidade ${ }^{(1)}$

\begin{tabular}{|c|c|c|}
\hline Nacionalidade & $N^{0}$ de Imovéis & 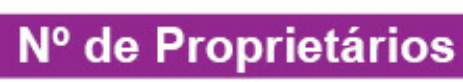 \\
\hline Portugueses & 1104 & 236 \\
\hline Italianos & 464 & 98 \\
\hline Arabes & 229 & 54 \\
\hline Outros: & 257 & 81 \\
\hline Subtotal & 2054 & 469 \\
\hline Coreanos +2 & 86 & 36 \\
\hline Total & 2140 & 505 \\
\hline
\end{tabular}

(1)Foi incluído, também, 5 (cinco) imóveis pertencentes, cada um, a uma pessoa, porque se tratava de ímóvel de grande dimensão

Os proprietários Pessoa Física são os que possuem o maior número de imóveis. Foram escolhidas as nacionalidades com maior influência na produção do espaço urbano e que possuem 2 ou mais imóveis. Cada nacionalidade tem sua representatividade mapeada.

O critério de importância para apresentar as nacionalidades dos proprietários foi quanto:

1. a relação da nacionalidade com o zelo do ambiente construído.

2. a importância e a influência na produção do espaço urbano.

3. ao número de imóveis de cada nacionalidade de proprietários.

Convém ressaltar que no Pari existe um número muito grande de bolivianos, mas não foi possível identificar se possuem propriedades. Sabe-se que a condição da maioria dos bolivianos que moram e trabalham no Pari é de extrema exploração. Fazemos referência a essa questão no item sobre a história social do Pari. 
Retomando a classificação dos imóveis por nacionalidade:

a - Coreanos

Dos proprietários estrangeiros, os mais relevantes são os coreanos, por sua participação efetiva na reprodução do espaço urbano no Pari nas duas últimas décadas. Se há alguma mudança na paisagem, isso se deve particularmente a eles. Chegaram no final da década de 80 , com intenção clara de se instalar e tornar São Paulo sua cidade, desenvolvendo toda uma prática cotidiana inserida no bairro, como as atividades religiosas e comerciais. Investiram na melhoria de seus imóveis com diversas reformas arquitetônicas, transformando o aspecto de alguns pontos do bairro. Numa paisagem em que a grande maioria das edificações continua sem conservação, em estado precário, dando à área uma feição deteriorada, destacam-se com nitidez a qualidade e a conservação dos imóveis dos coreanos.

O investimento de capital não se limitou à aparência dos imóveis, mas também se fez presente na produção do setor de confecções, principalmente. Os coreanos, mesmo em seu país de origem, revelam aptidão, ou preferência, em lidar com indústrias têxteis e atividades derivadas. E, em São Paulo, essa atividade se expandiu.

No bairro, 203 imóveis (Mapa 23) pertencem a 146 coreanos (3,9\% dos imóveis). Destes, 14 são Igrejas Presbiterianas Coreanas (SF/ PMSP, 2006). 
Mapa 23 - Número de propriedades de coreanos por quadra

- Distrito do Pari - 2006

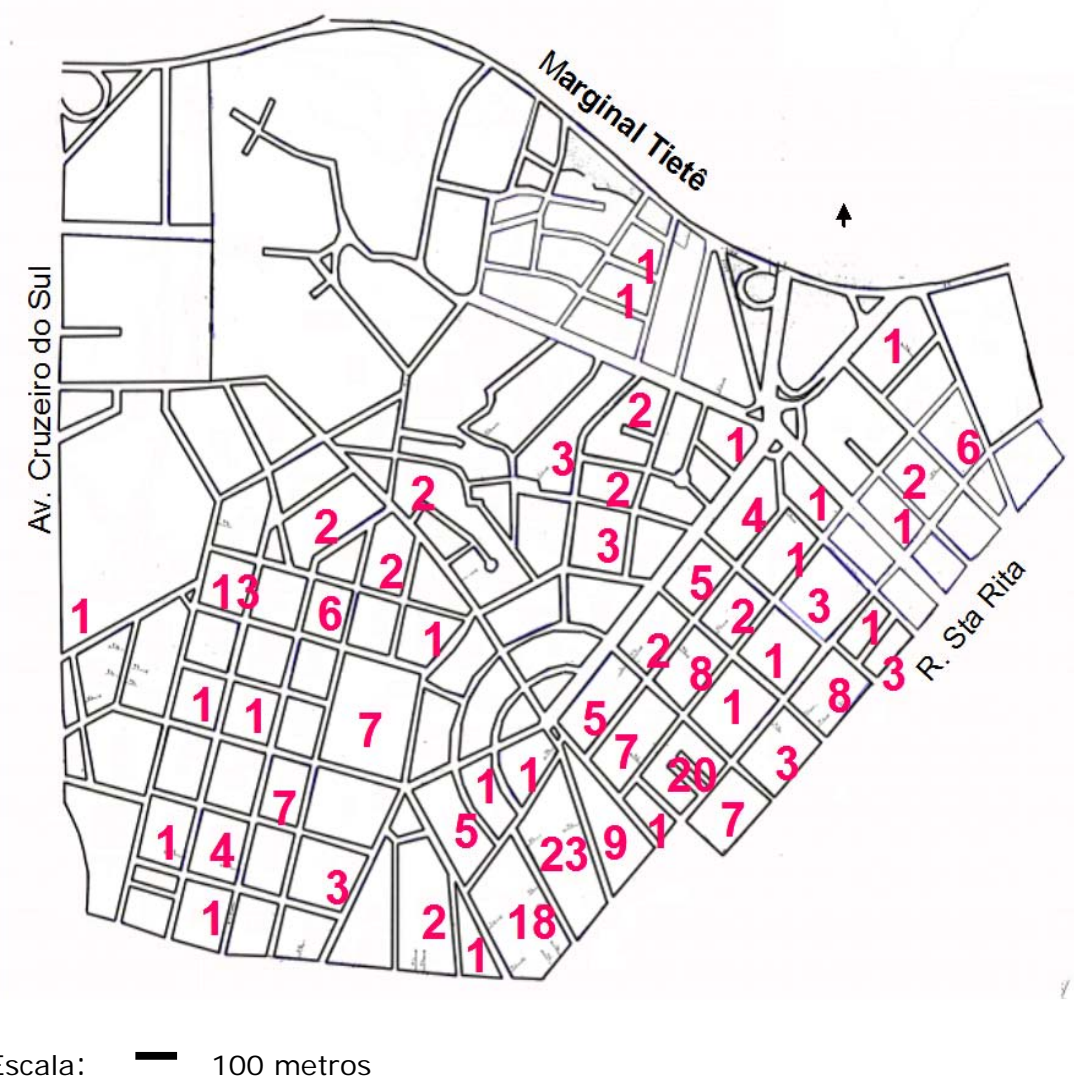

Fonte SF/PMSP, 2006

Foto 31 - I grejas Presbiterianas Coreanas
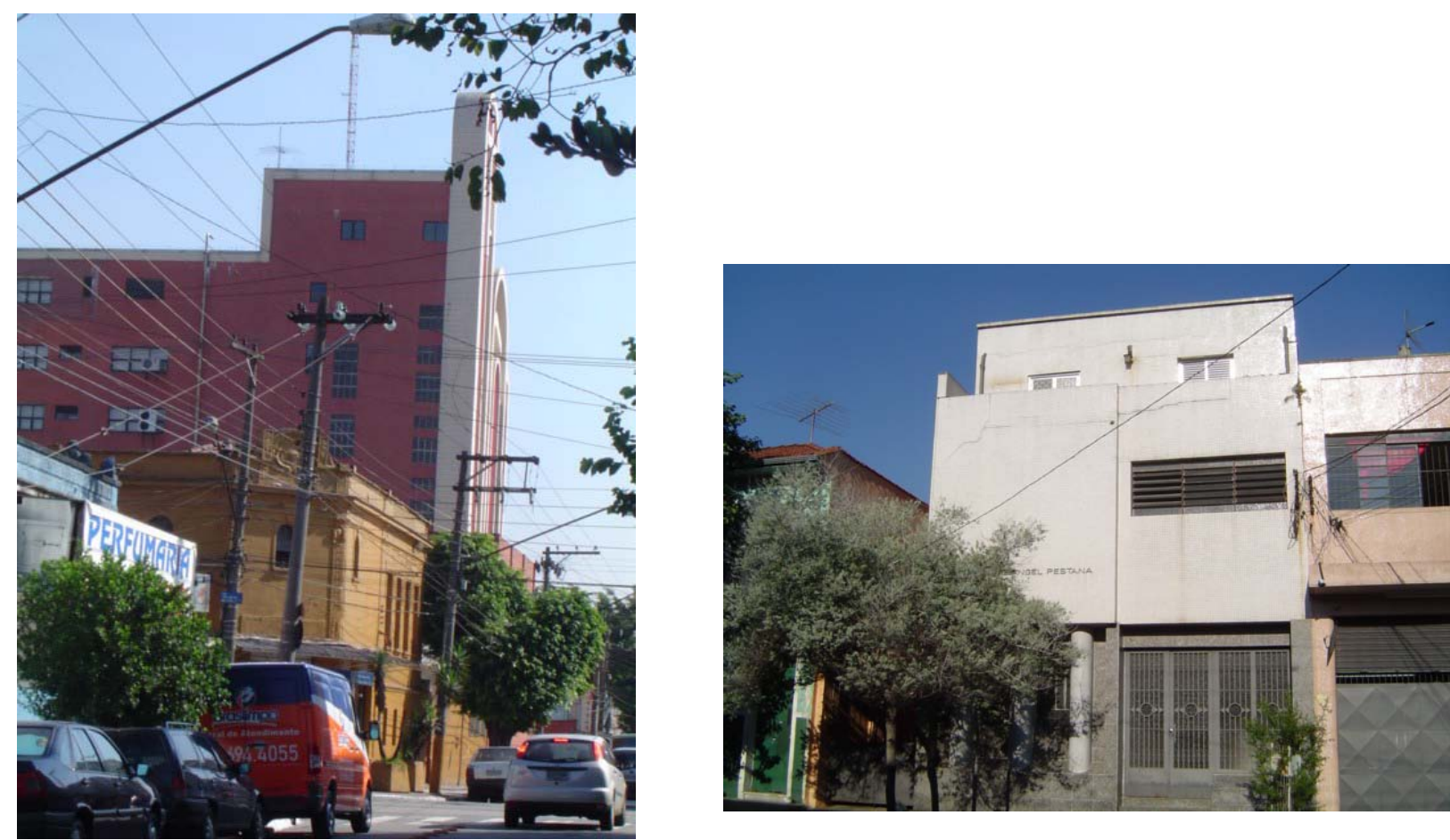


\section{b - Portugueses}

Os portugueses, os primeiros habitantes do distrito do Pari, são os maiores proprietários de imóveis (Mapa 24), desde o início, quando eram donos das antigas chácaras, que posteriormente foram loteadas.

A aplicação de questionários na área possibilitou dialogar, também, com os entrevistados. Dessa conversa informal, os habitantes e frequentadores contaram muito da história do Pari e do comportamento de seus habitantes. Destaca-se a opinião comum sobre os portugueses: “Eles não vendem seus imóveis de jeito nenhum e, ao colocar para alugar, não rebaixam o preço. Preferem deixar o imóvel fechado a ter de alugar com preço menor que o desejado". Conclui-se que muitos imóveis estejam fechados em virtude dessa postura. Apesar do fato de que o direito de propriedade significa ter direitos individuais de usar, gozar e dispor da propriedade, a Constituição Federal reza em seu artigo 182, $\S 2^{\circ}$ : “A propriedade urbana cumpre sua função social quando atende às exigências fundamentais de ordenação da cidade expressas no Plano diretor". Logo, o direito de propriedade é limitado pelo interesse social e deve cumprir a função social, qual seja, dar uso ao imóvel e não guardálo para garantir valorizações futuras. A atitude dos portugueses caracteriza uma herança patrimonialista, de cunho individualista, civilista, no sentido de afirmar o patrimônio individual contra os interesses sociais, ambientais e culturais. Outras nacionalidades se comportam de forma diferente, como se verá mais adiante. 


\section{Mapas 24 - Número de propriedades de portugueses por quadra - Distrito do Pari - 2006}

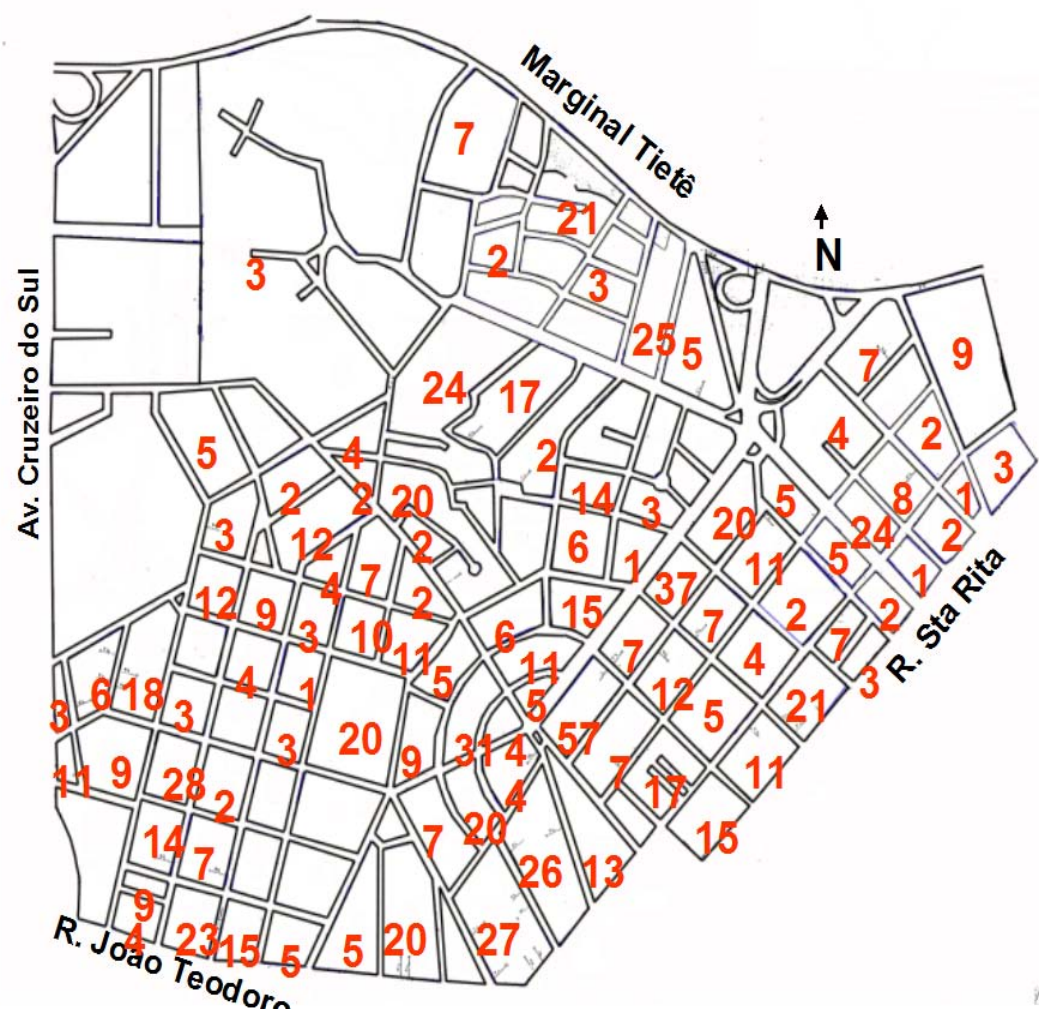

Escala: $\quad 100$ metros

Fonte SF/PMSP, 2006

C - Italianos

Os italianos estão posicionados em segundo lugar na hierarquia de proprietários por número de imóveis no Pari (Mapa 25). Sabe-se muito pouco da característica típica do italiano do bairro quanto à relação com seus imóveis. Nas entrevistas, nada ficou explícito, ou seja, eles não foram mencionados de forma peculiar. Sabe-se apenas que, assim como os portugueses, foram proprietários das antigas chácaras, sendo portanto moradores antigos do local.

A descrição histórica da inserção dos imigrantes italianos em São Paulo sempre dá grande destaque ao bairro do Brás - o mais italiano dos bairros paulistanos -, além do Bom Retiro, Bexiga, Barra funda e Moóca. O Pari não costuma ser mencionado, não sabemos se por uma atitude 
negligente em relação ao bairro ou se devido a sua proximidade com o Brás, considerando-os, assim, um bairro único.

No entanto, as características marcantes do ambiente típico dos trabalhadores do Brás, Moóca, Belenzinho e Barra Funda são visíveis no distrito do Pari. As habitações se sucedem, uma após a uma, todas mais ou menos iguais, de estilo pobre, em filas intermináveis, numa monotonia e humildade sem fim. Ladeando as habitações pobres, uma fábrica ou pequenas oficinas (Foto $\mathbf{2 3}$ ).

\section{Mapa 25 - Número de propriedades de italianos por quadra - Distrito do Pari - 2006}

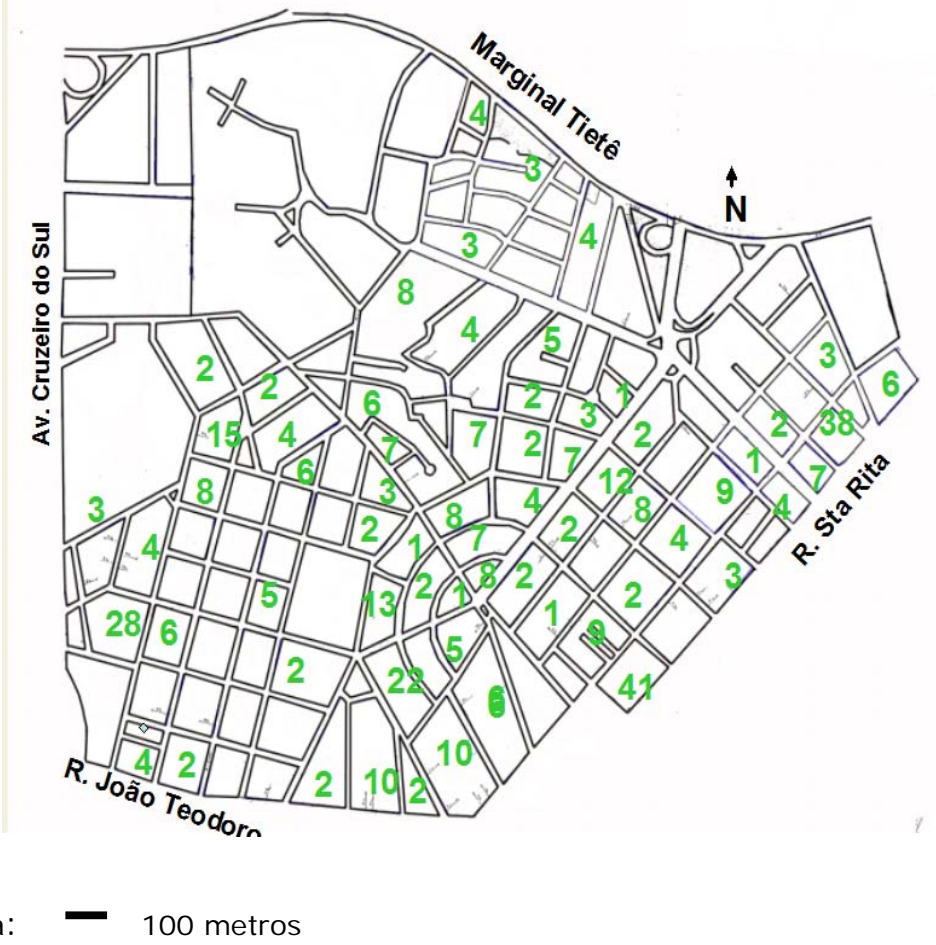

Fonte SF/PMSP, 2006 
Foto 32 - casas enfileiradas e indústria ao fundo
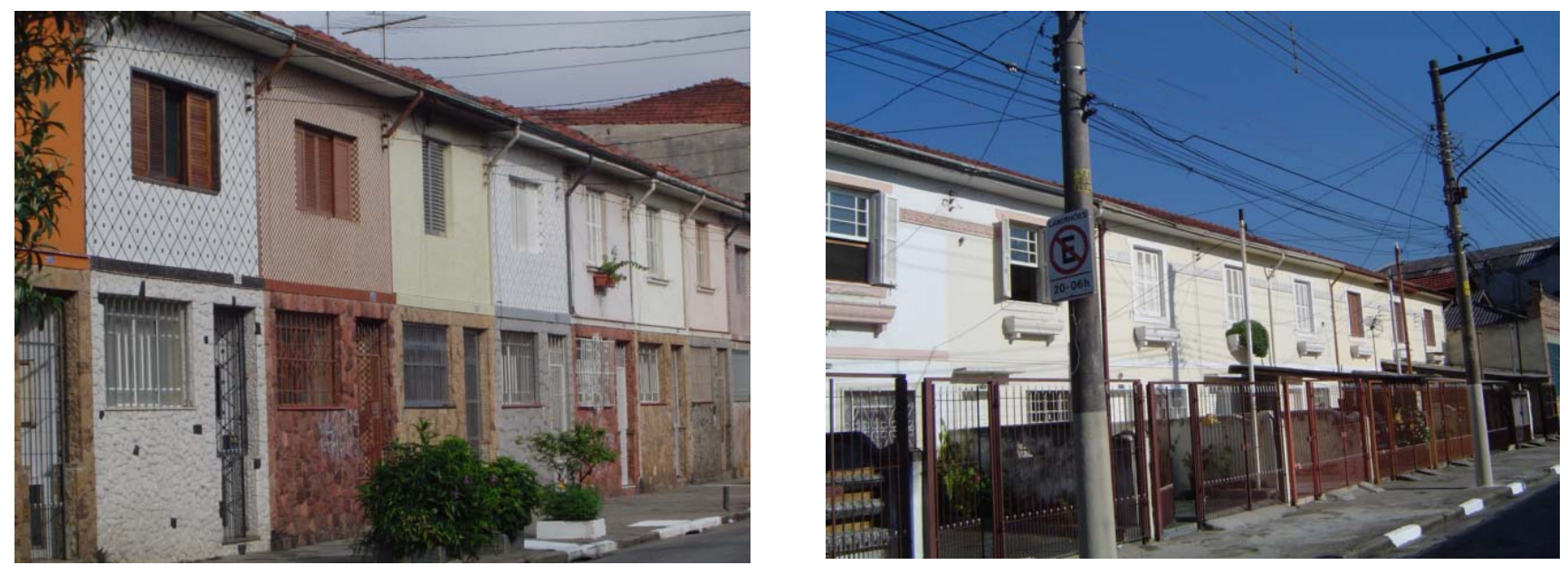

d - Os árabes

Os árabes chegaram depois de 1950, mas são os maiores proprietários individuais de imóveis do bairro (Mapa 26), e formam uma comunidade muito forte, e atuante. Há duas mesquitas, uma associação beneficente e uma liga da Juventude Islâmica. Existem, também, vários restaurantes de comida árabe.

O proprietário do Pari com maior número de imóveis, individualmente, é árabe e possui 40 imóveis. É um grande comerciante, possui um prédio (Foto 33), além de vários outros imóveis residenciais e comerciais. Nas entrevistas comentou-se muito que os árabes, ao contrário dos portugueses, não deixam seus imóveis vazios. Sempre alugam, mesmo que tenham que baixar o preço do aluguel, e assim seus imóveis estão sempre ocupados. É importante ressaltar que um imóvel ocupado deteriora-se, em geral, menos do que um vazio. 
Mapa 26 - Número de propriedades de árabes por quadra Distrito do Pari - 2006

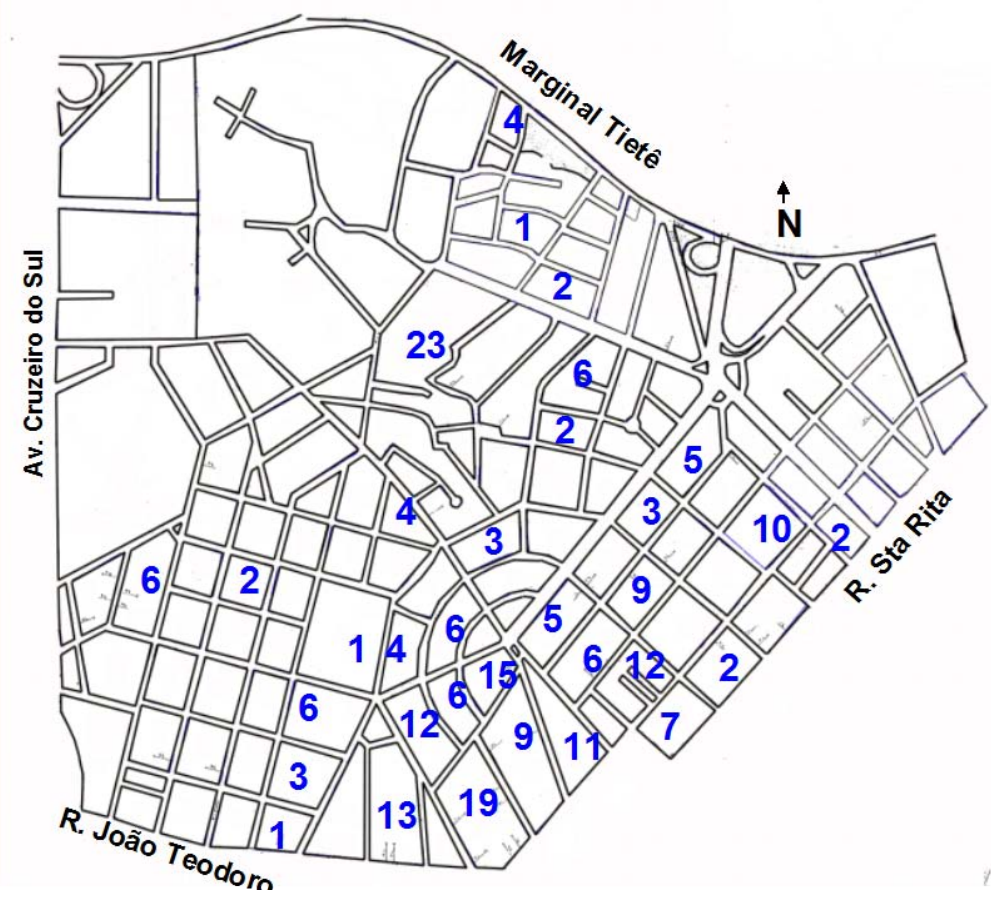

Escala: - 100 metros

Fonte SF/PMSP, 2006 
Foto 33 - Edifício de uma família árabe - Alto do Pari - 2006

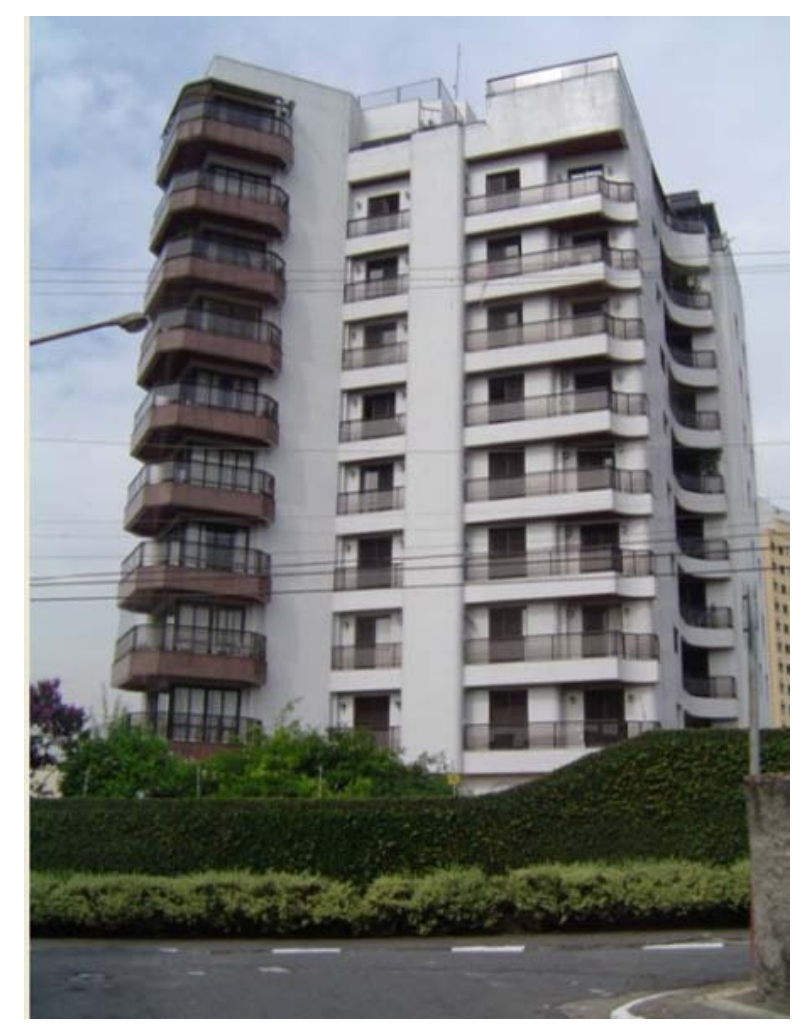

e - Os outros

As outras nacionalidades com incidência forte no bairro são principalmente espanhóis, judeus, armênios, gregos, chineses e japoneses (Mapa 27). Há pouco a destacar sobre esses estrangeiros e seus descendentes, apenas pode-se afirmar que, assim como os árabes, os judeus não deixam seus imóveis vazios - comentário dos entrevistados. Dos chineses salientou-se que são na grande maioria comerciantes. Aliás, todos os proprietários estrangeiros do Pari são, em geral, comerciantes ou industriais. 


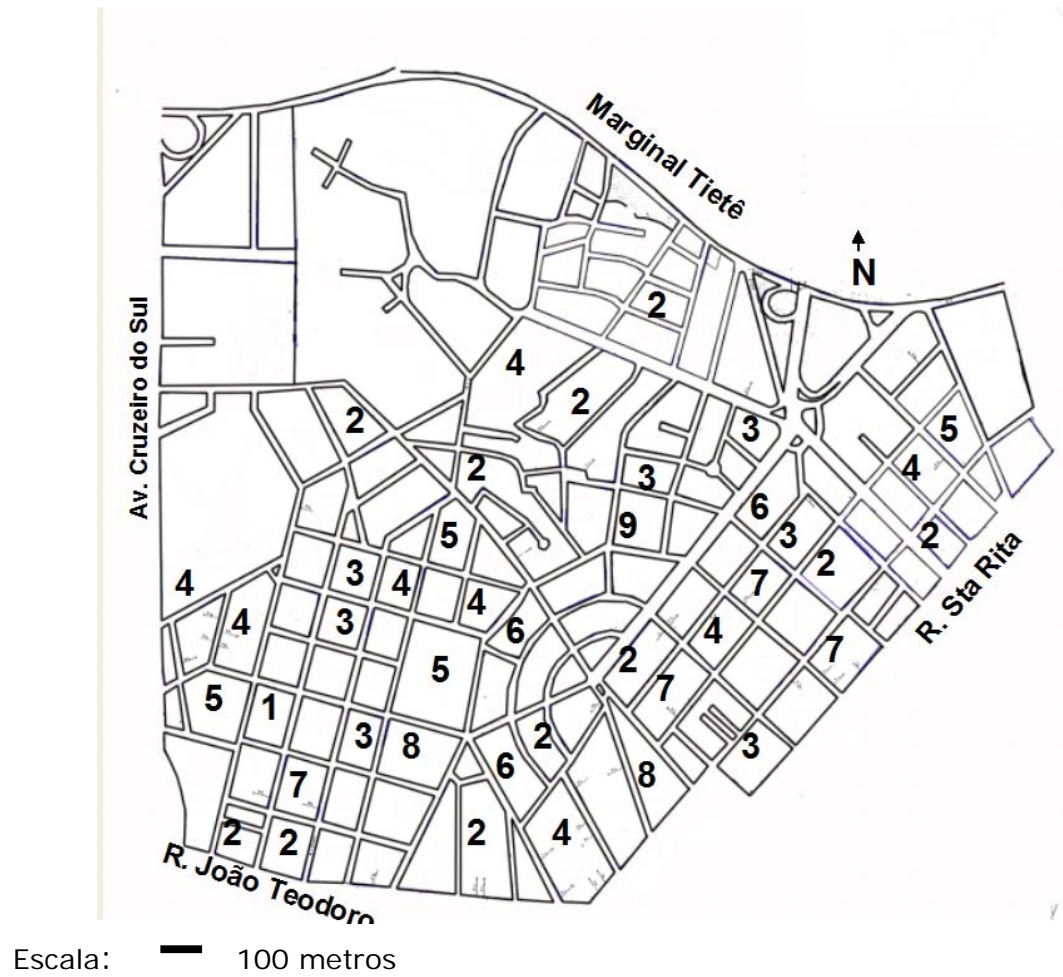

Fonte SF/PMSP, 2006

Percebe-se que a distribuição dos imóveis por nacionalidade é bastante homogênea. Os portugueses praticamente possuem dois imóveis ou mais no distrito todo. Não há uma parte do bairro onde uma nacionalidade pesa mais que outras. Podemos até dizer que os coreanos, como os árabes, possuem imóveis predominantemente na parte leste do distrito e os portugueses, mais acentuadamente, na parte oeste.

Sobre essa questão de nacionalidades caberia um estudo mais aprofundado, com um viés antropológico, que nesse estudo não procede. Porém, é muito interessante perceber como se dá o entrosamento dos imigrantes na cidade. É nítido o sentimento de pertencimento ao bairro e à cidade. É comum ouvir relatos contundentes sobre a escolha pelo Brasil em que o imigrante se mostra totalmente satisfeito e integrado.

A concentração de imóveis nas mãos de poucos também é um fato comum, que não nos surpreende, diante da porcentagem de imóveis 
alugados. Pode-se afirmar que a concentração de propriedades justifica o grande número de imóveis de aluguel.

Diante desses resultados, nos fazemos a pergunta: esse processo pode ser extrapolado para outras áreas semelhantes no município? Ou seja, o que acontece numa parte da cidade se reproduz em um universo maior?

Ao analisar o movimento dos dados sobre demografia, empregos ou situação financeira da população residente no Pari notamos semelhanças com outras áreas estagnadas. Pode-se, então, conceber que a mesma dinâmica - a concentração de propriedades - ocorra em outras partes da cidade. Há uma curiosidade a ser relatada: como os nomes dos proprietários foram lidos e relidos, acabamos por perceber que pelo menos três deles aparecem como proprietários de imóveis em outras áreas da cidade.

- $\quad$ Propriedades de Pessoas Jurídicas

O total de imóveis em nome de Pessoas Jurídicas é de 577. Constatamos que 229 pertencem a imobiliárias, 207 a empresas, 85 a entidades públicas, municipais, estaduais e federais, e 56 a entidades religiosas.

Tabela 16 - Propriedades Pessoa Jurídica

\begin{tabular}{|l|c|}
\hline Nacionalidade & $\mathbf{N}^{0}$ de Imovéis \\
\hline Imobiliárias & 229 \\
Empresas & 207 \\
Públicas & 85 \\
Entidades Religiosas & 56 \\
& Total
\end{tabular}

Fonte: SF/PMSP, 2006 


\section{a - Imobiliárias}

Os dados relativos às imobiliários recaem também sobre terrenos (propriedade fundiária) e não apenas sobre imóveis construídos. Essa diferença com os outros proprietários é importante, sobretudo porque as imobiliárias são quase os únicos a imobilizarem propriedade fundiária, por terem sempre necessidade de reter terrenos para incorporação, com intenção especulativa ou não. É preciso, portanto, compreender se acontece o fenômeno de retenção especulativa no bairro. Apesar de o setor imobiliário envolver a indústria da construção civil e as atividades terciárias ligadas a ele, é importante destacar se há atividade imobiliária incorporadora que detém e acumula propriedades para produzir edifícios residenciais ou não residenciais. Mesmo que não seja propriedade de imobiliárias, existem proprietários que não têm a preocupação em produzir, usar ou mesmo conservar seus imóveis em boas condições de habitabilidade, e os guardam na expectativa de uma valorização futura.

No Pari, entre 1992 e 2007, o número de lançamentos de edificações residenciais verticais foi de apenas 2 edifícios (SEMPLA/DIPRO, 2008) e não houve lançamentos verticais não residenciais. Parece que o número de imóveis em nome de imobiliárias se dá, muita vezes, em razão do financiamento do imóvel. Nos casos de financiamentos ainda não concluídos, a titularidade do imóvel recai sobre a imobiliária até o final do financiamento.

As construções de novas edificações nas diversas atividades e usos e a construção de infraestrutura são atividades geradoras de melhorias importantes para um processo ativo do bairro. No entanto, essas atividades não foram percebidas com nitidez na pesquisa, por isso fazemos referência apenas a retenção de imóveis sob titularidade das imobiliárias.

No Pari, são 43 imobiliárias que possuem 229 imóveis (3,6\%). (SF /PMSP, 2006) A foto 5 mostra edifícios nos quais mais de $70 \%$ das unidades estão em nome de uma imobiliária. 
Foto 34 - Edifícios com $70 \%$ das unidades em nome de uma imobiliária

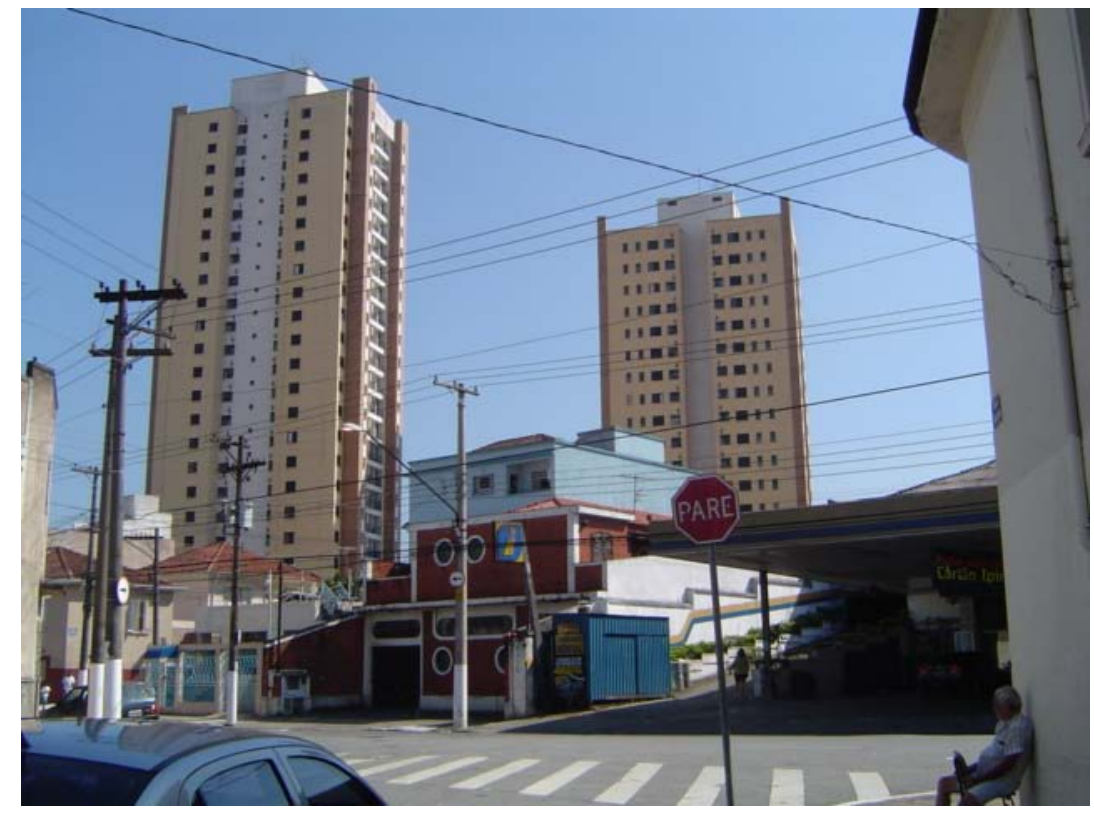

Rua Padre Vieira - Pari - 2006

\section{b - Empresas}

Outro tipo de propriedade Pessoa Jurídica identificado na pesquisa são os imóveis que pertencem a empresas. As empresas têm grande visibilidade no bairro, não apenas pelo seu número, mas também pela dimensão e, consequentemente, pelo espaço que ocupa no bairro. Os imóveis de empresas não surpreendem pela quantidade (Foto 35), mas porque, assim como os terrenos públicos e entidades religiosas, são áreas grandes, muitas delas indústrias de doces ou atacadistas de mercadorias que necessitam de terrenos amplos para estacionamento de veículos de grande porte, como caminhões e ônibus.

Há 1.740 imóveis $(24,4 \%)$ com destinação de comércio (varejo e atacadista), serviço, indústria e oficinas, mesmo que nem todos estejam registrados em nome de pessoa jurídica. Merece destaque o grande número de oficinas e bares (74 e 71 respectivamente), cuja presença se revela em todas as quadras. Em registro oficial pelo Sistema Unificado de Cadastro (SUC) da PMSP, existem 103 empresas para 207 imóveis (SF/ PMSP, 2006). Nota-se então que a maioria das empresas possui registro 
como Pessoa Física. Isso ocorre provavelmente por dois motivos: a titularidade está no nome de pessoa física e o licenciamento da atividade está no nome da empresa ou a atividade possui funcionamento irregular. Fato corriqueiro da vida cotidiana paulistana.

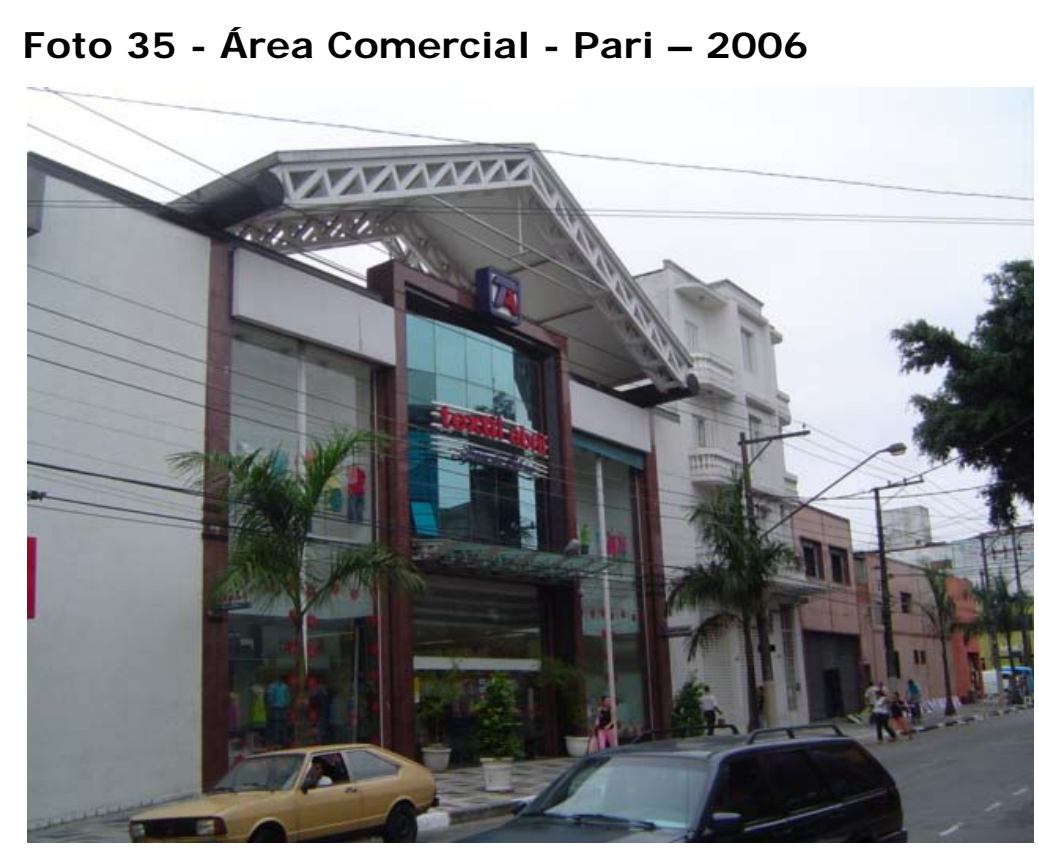

c - Áreas públicas

O Pari foi formado abarcando o antigo leito do rio Tietê (mapa 28). Grande parte desses terrenos, que eram terras devolutas, pertence, ainda, ao Estado ou à Prefeitura; outros foram apropriados por particulares ou instituições privadas.

Até 1958, não havia inventário sobre os terrenos do município advindos da retificação do rio Tietê. A transferência de domínio das terras públicas representou a um só tempo a ampliação da arrecadação, tanto imediata, através da Taxa de Legitimação, quanto em longo prazo, através do IPTU e pela possibilidade de atendimento de parte das reivindicações populares referentes à regularização dominial das terras ocupadas. 


\section{Mapa 28 - Distrito do Pari em 1942 destacando a várzea do Tietê, então áreas devolutas}

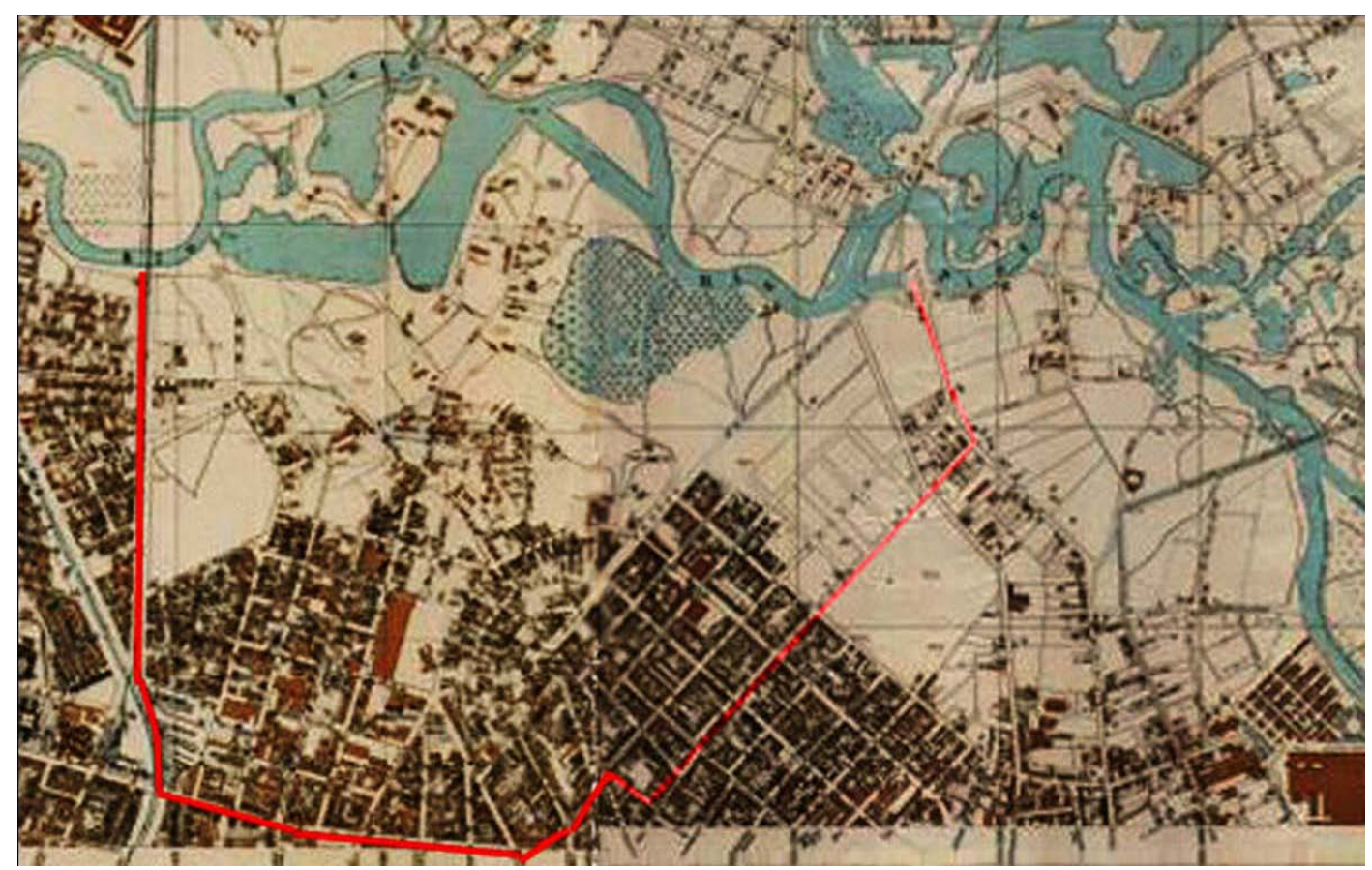

Fonte: Sara Brasil (SEMPLA?PMSP)

Das terras devolutas, muitas foram legalizadas pelos posseiros que viviam na área geração após geração e que continuam presentes nos nomes de ruas do bairro que ficaram impressos e se perpetuam até hoje. Poucos herdeiros possuem os imóveis transmitidos. Houve acentuada alienação dos imóveis de antigos para novos proprietários.

Os imóveis públicos não são numerosos, mas, na maioria, possuem grandes extensões. Como na pesquisa a contagem foi por número de terrenos, e esse número não é significativo, consideramos importante visualizar o mapa da área, para perceber a grande expressão que a propriedade pública possui no ambiente do bairro como um todo (mapa 15, pg. 81 ).

Os imóveis pertencentes ao poder público - Prefeitura, Estado e empresas estatais - somam 79 lotes.

d. Instituição religiosa 
Em outros trabalhos ${ }^{1}$ demonstrou-se que a Igreja (católica) foi a proprietária de freguesias inteiras em São Paulo. No “Registros de Terras de São Paulo" encontra-se a escrituração referente às freguesias. No caso do Pari, a área pertencia à Freguesia da Sé ${ }^{2}$. O registro de terras instituído pelo Regulamento de 1854 - denominado Registro do Vigário ficava sob o controle das paróquias da Igreja e tinha efeito prático para conferir legitimidade pública às terras privadas, apesar da imprecisão das demarcações. Em especial, garantia à propriedade o cumprimento de sua função absoluta e tentava criar uma nova mentalidade no que concerne ao direito da propriedade e ao acesso à terra. (CASTILHO, 1993).

Em todo esse processo, ao longo da segunda metade do século XIX, o Estado manteve posição dúbia e indefinida, perpetuando até os dias de hoje a dificuldade na discriminação e legitimidade da propriedade da terra. Somente em 1890, seria instituído, facultativamente, o registro de terras, conhecido como Registro Torrens ${ }^{3}$. As propriedades passaram a ser registradas em cartórios, com demarcação correta, comprovação e justificativa de posse. Assim, o Estado assegurava a propriedade, indicando seu lugar na estrutura espacial, a partir do que surgiu uma nova lógica de produzir e apropriar o espaço, e dando-Ihe a qualidade de mercadoria.

No distrito do Pari, os imóveis pertencentes a entidades religiosas (Mapa 29) não são em grande número, mas são, na maioria, áreas de grandes dimensões, principalmente os terrenos de propriedade da Igreja Católica. Destaca-se, nesse contexto, também, o grande número de igrejas coreanas, proporcionalmente em maior número que todas as outras religiões. Assim, por meio da pesquisa, pudemos conhecer a religião dos moradores e frequentadores do bairro.

São 29 entidades religiosas que ocupam 56 imóveis distribuídos da seguinte forma:

\footnotetext{
${ }^{1}$ Botelho, Adriano; Castilho, Ricardo e Seabra, Odette

2 “A paróquia da Sé, logo após a independência (já então sé ou sede do bispado), desdobra-se em Santa Ifigênia, e depois Brás, formando três paróquias" (MARX, M. 1988: 113; apud

CASTILHO, R. 1993:56)

${ }^{3}$ Conceituado na página 124
} 
Tabela 17 - Entidades Religiosas - Distrito do Pari - 2006

\begin{tabular}{|lcc|}
\hline Entidades & Quantidade & $\begin{array}{c}\text { Número de } \\
\text { Imóveis }\end{array}$ \\
\hline Islâmicas & 2 & 2 \\
Judaicas & 3 & 5 \\
Coreanas & 8 & 15 \\
Católicas & 9 & 24 \\
Evangélicas & 3 & 6 \\
Espíritas & 3 & 3 \\
Outros & 1 & 1 \\
\hline \multicolumn{1}{|c}{ Total } & $\mathbf{2 9}$ & $\mathbf{5 6}$ \\
\hline
\end{tabular}

Mapa 29 - Entidades religiosas - Distrito do Pari - 2006

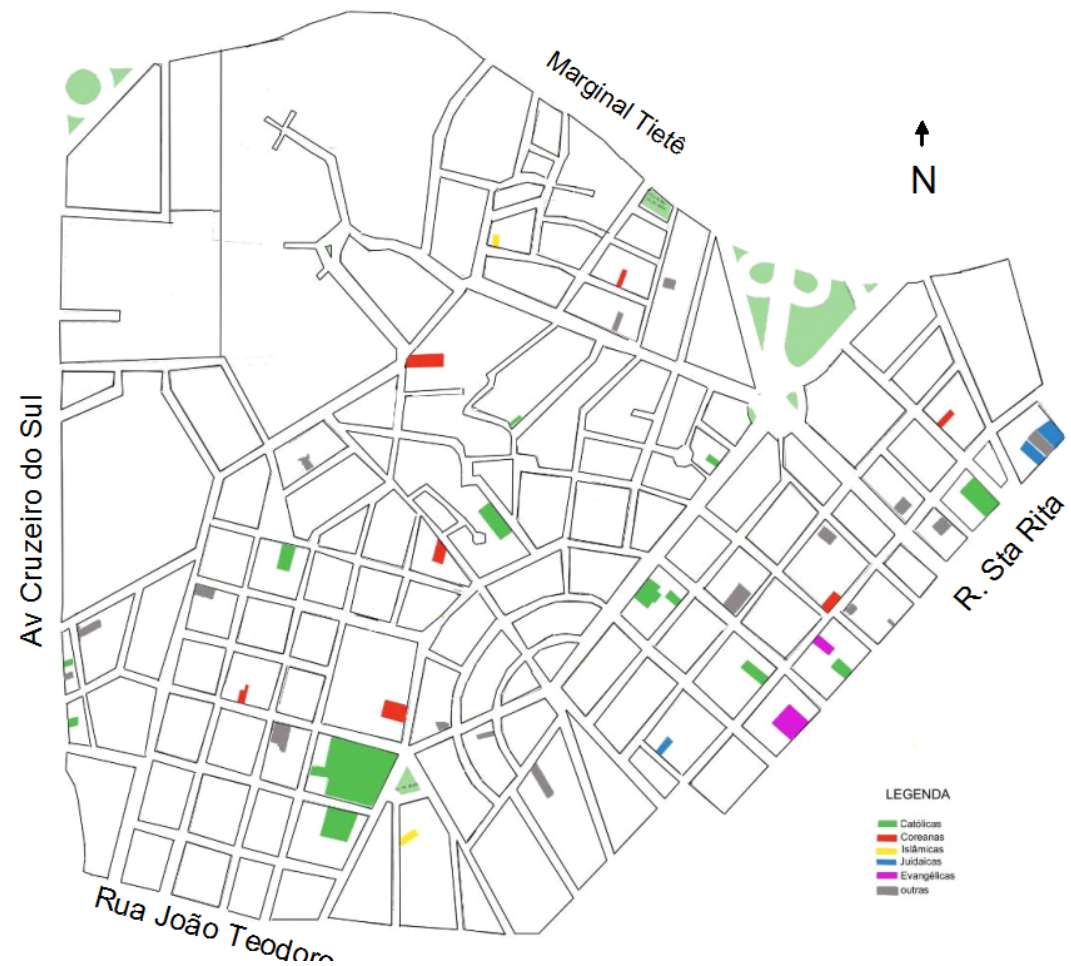

Escala: - 100 metros

Fonte : contagem in loco, 2006 
Cabe enfatizar que a propriedade imobiliária no Pari tem relação estreita com o modo de vida da população, com a comercialização de seus imóveis, com a expectativa de vida dos habitantes e também com a propensão dos jovens em criar (ou não) raízes no bairro. A concentração de imóveis pode ser medida em função dos domicílios existentes em relação ao número de 2 imóveis ou mais $(2.140,37,1 \%$ do total) em nome de 505 titulares (12,2\% dos proprietários), que representam apenas 3,3\% da população residente (15.417). É importante frisar que a porcentagem de imóveis alugados é de $49 \%$, para uma porcentagem média no município de 21,6\% (Censo 2000, IBGE) .

Esses dados mostram a concentração da propriedade em nome de poucos. Infere-se então que a retenção de imóveis e a alta porcentagem de locatários são fruto da falta de interesse de investidores, da carência de manutenção e conservação das construções, o que dá ao bairro uma aparência de área abandonada e sem vida.

\section{IV - O preço da terra}

As considerações feitas a seguir tiveram como base os dados de imóveis do Departamento de Rendas Imobiliárias - RI - da Secretaria Municipal de Finanças. Recolhemos os dados do valor venal anual entre 1953 a 2006, por meio do mapa da PGV (Planta Genérica de Valores), na Biblioteca da Secretária de Finanças. O mapa registra o valor venal por frente de lote de cada quadra do município, valor reajustado anualmente por alíquotas diferenciadas em função do uso do imóvel (residencial, não residencial e terrenos) e progressivas em relação ao valor venal anterior. Para encontrar os valores venais dos anos anteriores a 1970, foi preciso recorrer à microfilmagem de arquivos no Departamento de Rendas Imobiliárias da Secretaria de Finanças.

A finalidade dessa pesquisa era encontrar a evolução do valor venal anual do distrito do Pari, entre 1953 e 2006, para verificar como foi o processo de valorização da área, pelo menos do ponto de vista do Estado, a fim de fazer uma comparação com os valores do mercado imobiliário. 
Entende-se que o preço da terra não pode existir sem o poder de monopólio da propriedade privada da terra e da capacidade de apropriação das rendas. Tanto a renda como a propriedade privada da terra são socialmente necessárias para a permanência do capitalismo. O preço da terra capta simultaneamente o caráter temporal da acumulação (registrada por movimentos na taxa de juros) e o caráter específico dos valores de usos materiais distribuídos no espaço e, portanto, une as considerações temporais e espaciais dentro de uma só estrutura definida pela lei do valor.

A propriedade é uma abstração concreta, é um processo de valor. O espaço-mercadoria é uma abstração que se materializa numa quantidade de dinheiro. Todo processo econômico contém uma quantidade de espaço que é uma quantidade de valor. Para compreender a segregação socioespacial no presente é preciso compreender que a propriedade é um equivalente de valor da riqueza social. O preço da terra urbana decorre de dois fatores conjuntos: de sua localização, enquanto acessibilidade socialmente produzida, e dos serviços de que dispõe (VILLAÇA, 1986).

Vimos como, no distrito do Pari, a propriedade de terra urbana se concentra nas mãos de poucos proprietários. Agora tentaremos analisar como tem sido, historicamente, o comportamento do valor venal $/ \mathrm{m}^{2}$ dos imóveis. Mesmo que não seja igual ao valor do preço, ele é uma medida que se modifica ao longo do tempo, determinada pelos investimentos públicos e por melhoramentos privados. Os dados foram corrigidos para uma mesma base, ou seja, todos estão no valor de 2006. O valor de 2006 tem como base o valor de dezembro de 2005 - assim é feita a atualização do valor venal pela Secretaria de Finanças para o cálculo do IPTU do ano seguinte. No estudo destacamos a localização dos maiores e menores valores de cada ano e os desenhamos no mapa do Pari para poder perceber sua evolução ano a ano. E também calculamos a média do valor por quadra porque esse é o dado que a Secretaria de Finanças e a Secretaria de Planejamento dispõem ao público. No entanto essa média pode ser distorcida em muitos pontos da cidade. No Pari pudemos verificar essa distorção nas quadras com frente para as ruas Silva Telles e Bresser - as frentes dessas ruas possuem valor muito mais alto que o das ruas de trás, quase o dobro. Nesse caso, a média distorce o real. 
Em 1953 (Mapa 30 e 31), os valores mais baixos eram os das áreas centradas na parte baixa, correspondente aos antigos leitos dos rios Tietê e Tamanduateí, e, portanto passível de enchentes. Mas, também, há algumas frentes de lote no Alto Pari, que apesar de ser apenas um pouco mais alto do que a várzea, estão em quadras com grande número de ocupação antiga, com lotes pequenos e que hoje são cortiços e habitações de baixo padrão. Com exceção, justamente, de um edifício de alto padrão, da família do maior proprietário do bairro, de construção recente (Foto $\mathbf{3 3}$ ).

Os valores mais altos desse ano se encontram na Rua João Teodoro e em suas transversais, ocupadas na época por comércio.

Mapa 30 - Valores venais mais baixos e mais altos de 1953 Pari

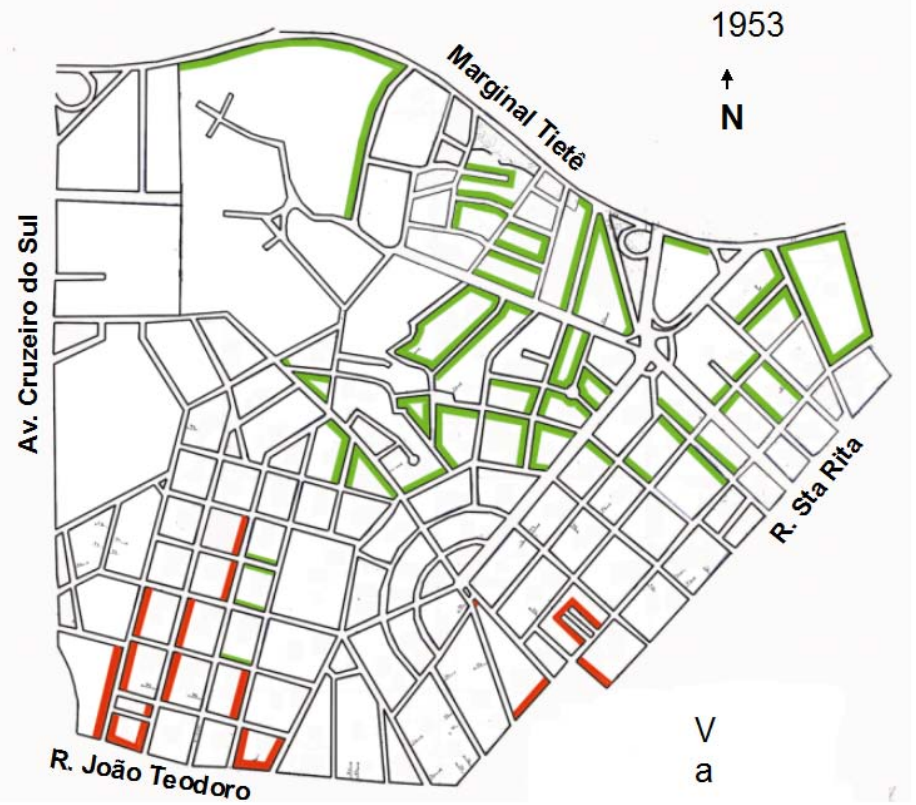

_ - Valores mais altos

_ - Valores mais baixos

Escala : _ _ 100 metros 


\section{Mapa 31 - Distrito do Pari}

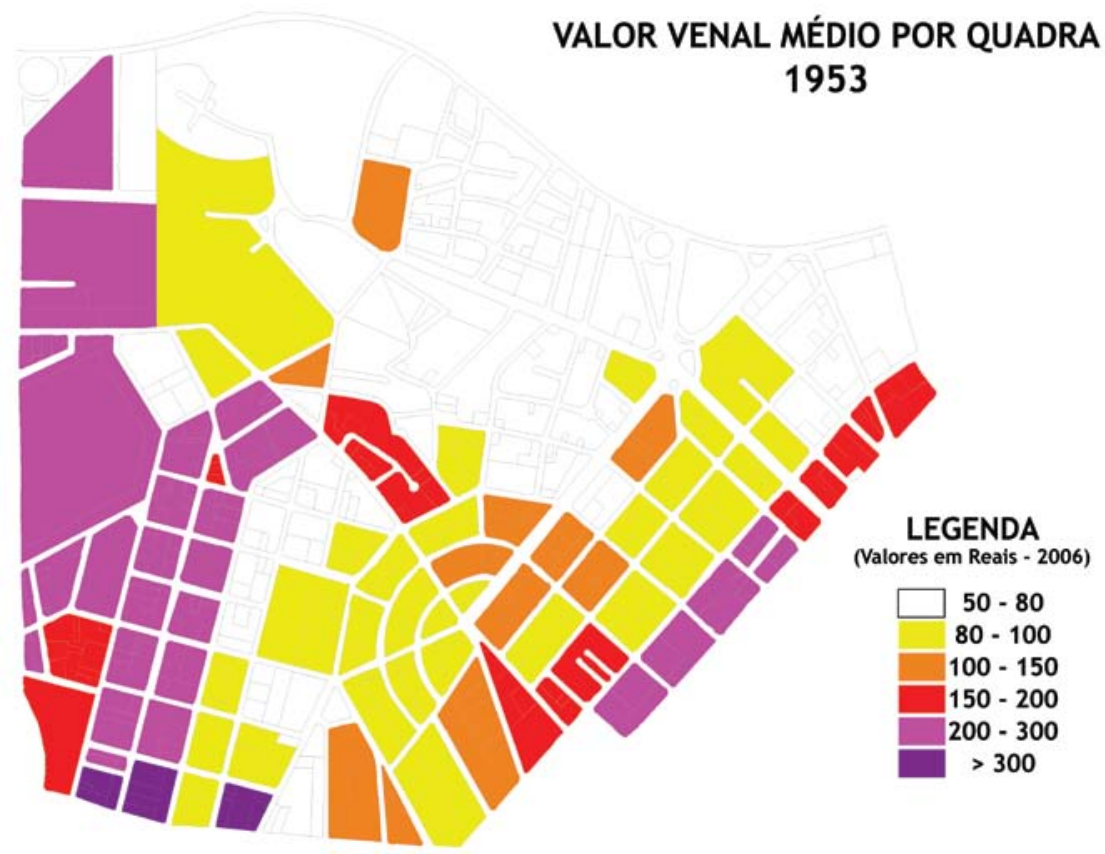

Em 1966 (Mapa 30 e 31), as áreas menos valorizadas se concentravam mais na área chamada Canindé, onde havia ainda enchente. Os valores mais altos se dispersaram em direção ao Brás, Rua Silva Telles e alguns pontos isolados.

Mapa 32 - Valores venais mais baixos e mais altos de 1966

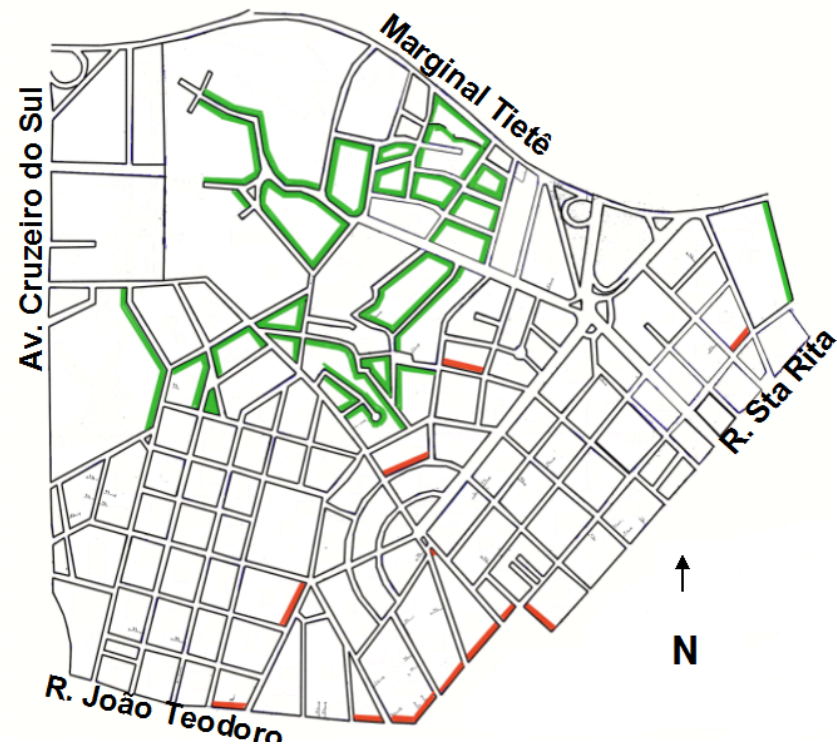

_ - Valores mais altos

_ Valores mais baixos

Escala : _ _ 100 metros 


\section{Mapa 33 - Distrito do Pari}

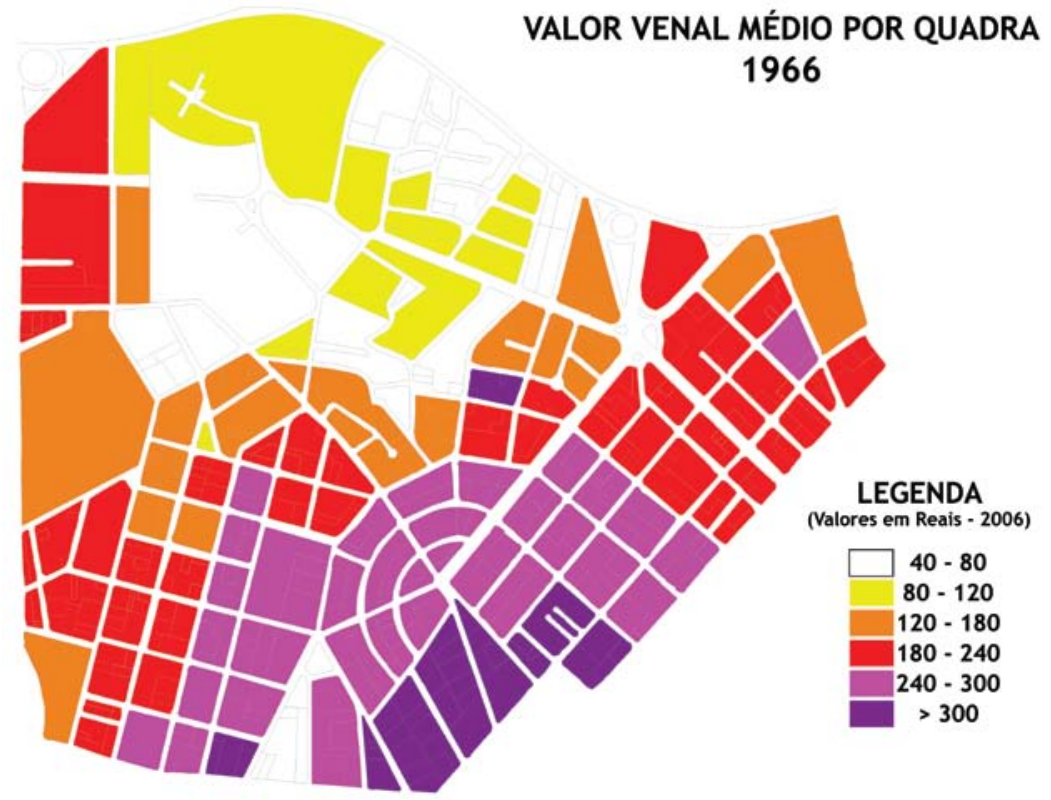

Em 1978 (Mapa 34), basicamente não houve quase alteração - os valores baixos continuavam na área do Canindé; os altos se concentraram nas áreas mais comerciais, a saber, Ruas João Teodoro, Silva Telles e Carlos Campos; e os médios repetiram a mesma situação anterior de 1966.

Mapa 34 - Valores venais mais baixos e mais altos de 1978

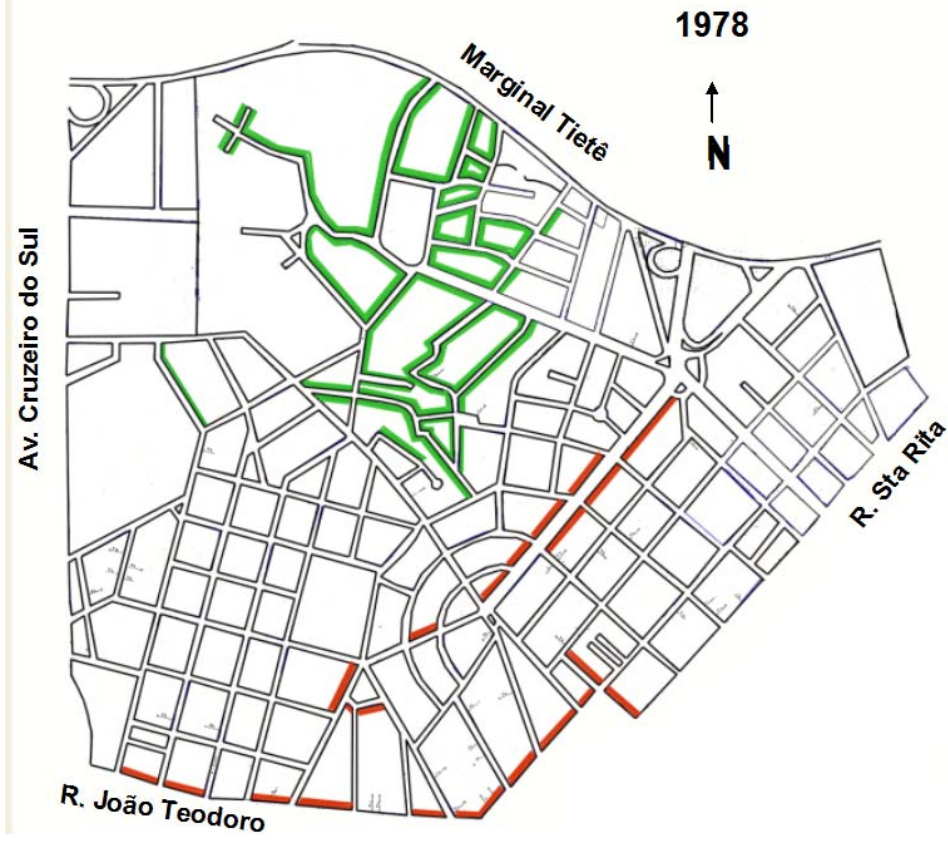

$$
\begin{aligned}
& \text { _ Valores mais altos } \\
& \text { _- Valores mais baixos } \\
& \text { Escala : _ _ } 100 \text { metros }
\end{aligned}
$$


Em 1990 (Mapa 35 e 36), os valores mais baixos se alteraram. A partir desse ano, as enchentes na várzea do rio Tietê diminuíram; por isso os valores venais mais baixos nessa área abrangeram uma superfície menor. A desvalorização, então, se direcionou para a área na qual há muitos imóveis abandonados e encortiçados - na Rua Canindé, Rua Madeira, Rua Afonso Arinos e sua continuação, Rua Hanemann e a Rua João Teodoro. Os valores mais altos se encontram nas áreas de maior ocorrência de usos comerciais, limítrofes ao distrito do Brás, basicamente nas ruas Silvia Telles e Bresser.

\section{Mapa 35 - Valores venais mais baixos e mais altos de 1990}

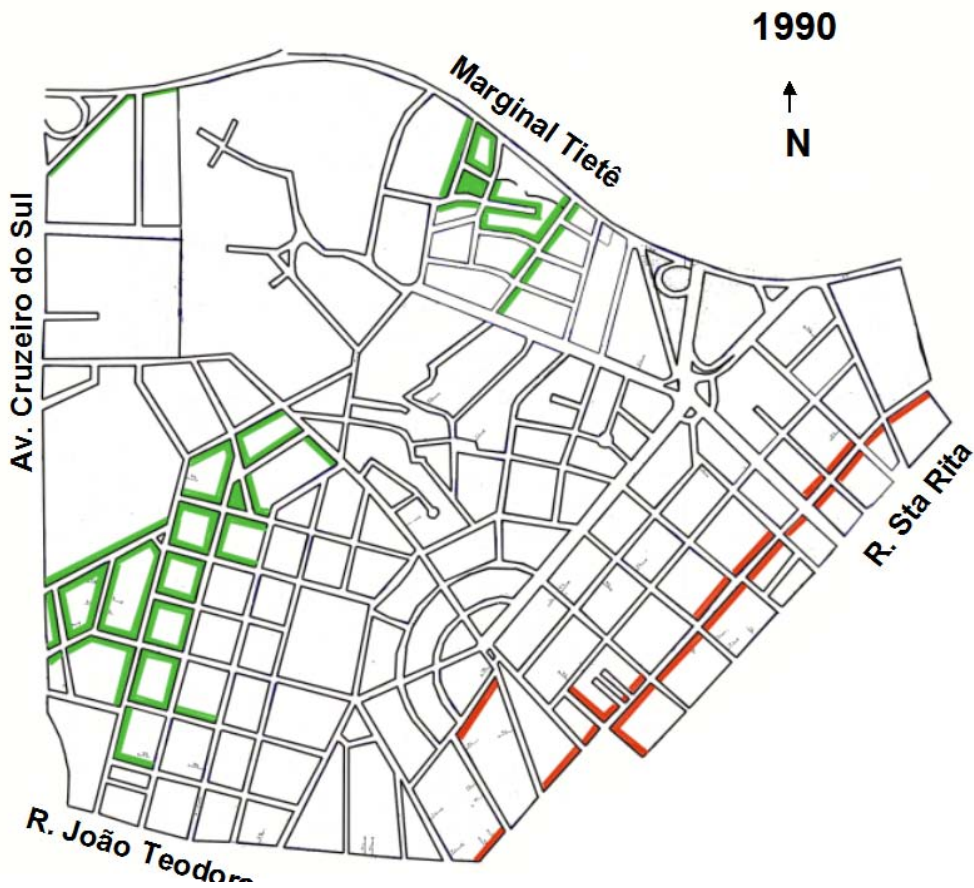

_ - Valores mais altos

_ - Valores mais baixos

Escala : _ _ 100 metros 


\section{Mapa 36 - Distrito do Pari}

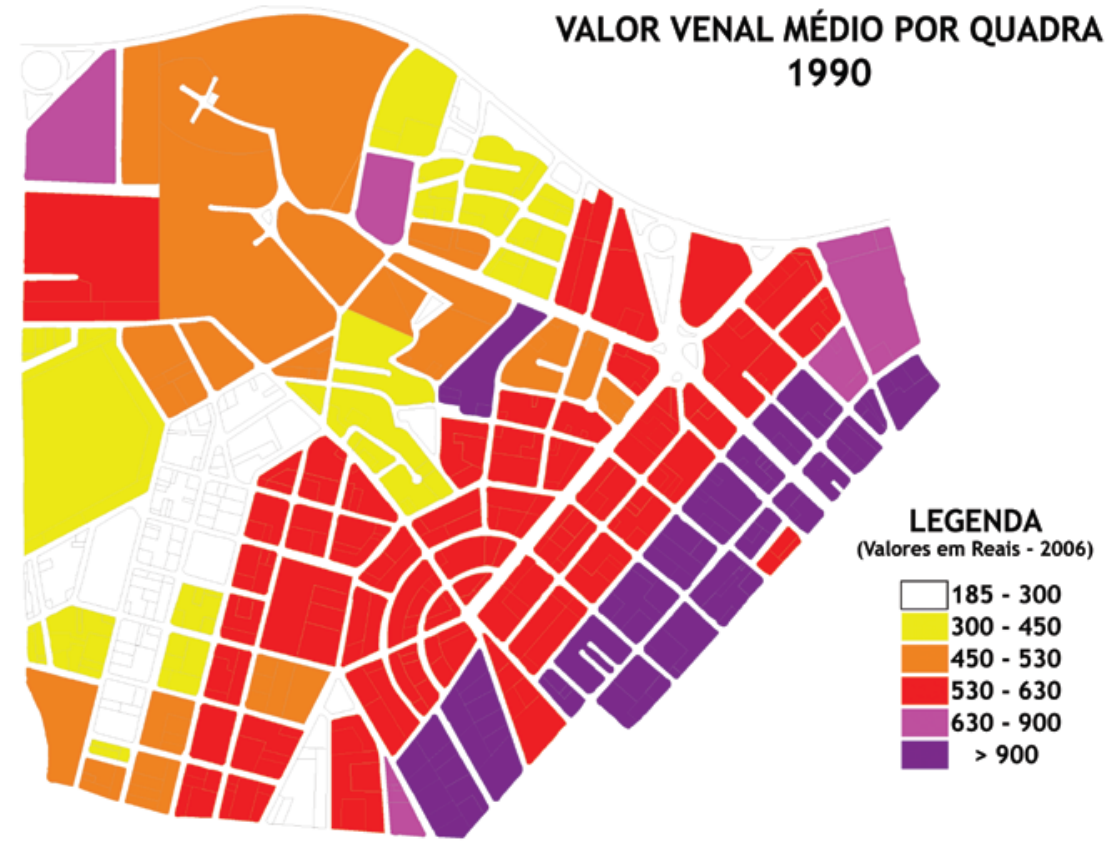

Em 2000, não houve mudanças nos valores mais baixos e mais altos das frentes de quadras. E em 2002 (Mapa 37) os valores médios pouco se alteraram.

\section{Mapa 37 - Distrito do Pari}

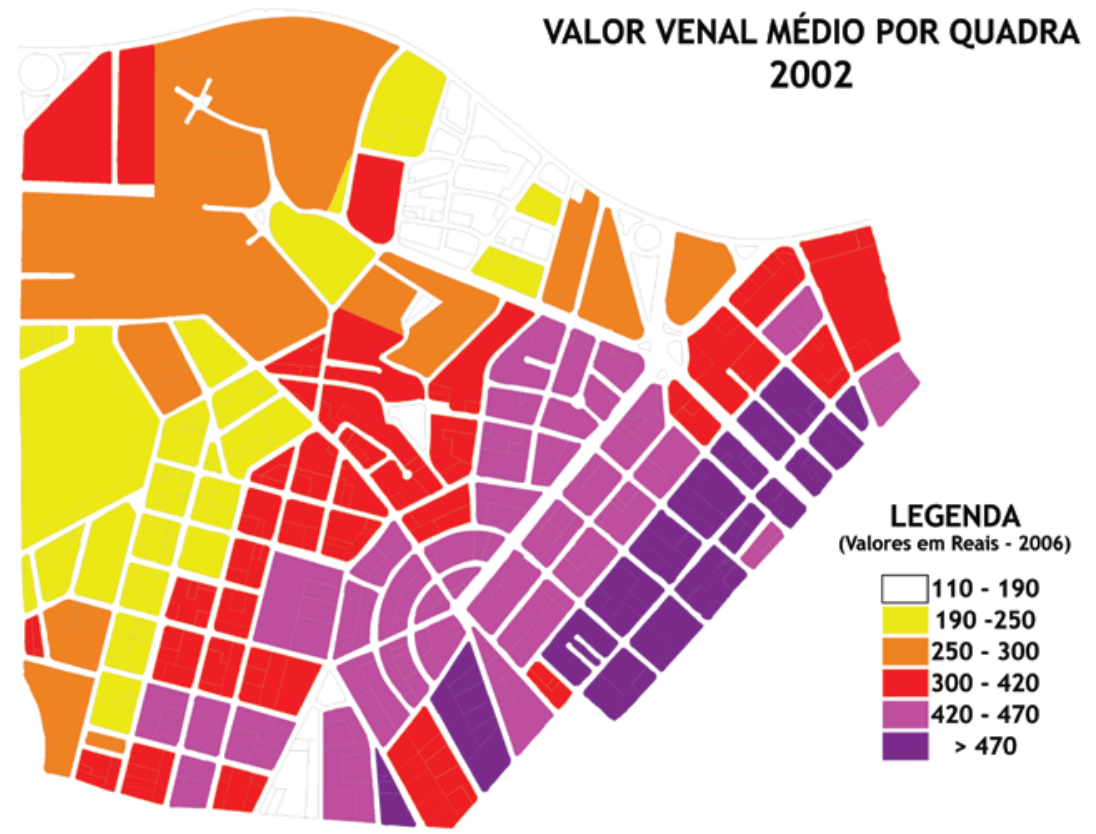


Em 2006 (Mapa 38) os valores continuaram quase iguais. As áreas baixas do Canindé, sobre as quais as cheias do rio Tietê se estendem, apresentavam as frentes de quadras com valores venais mais baixos, e a Rua Silva Telles e os dois quarteirões da Rua Bresser tinham os valores mais altos. Os valores médios se homogeneizaram mais.

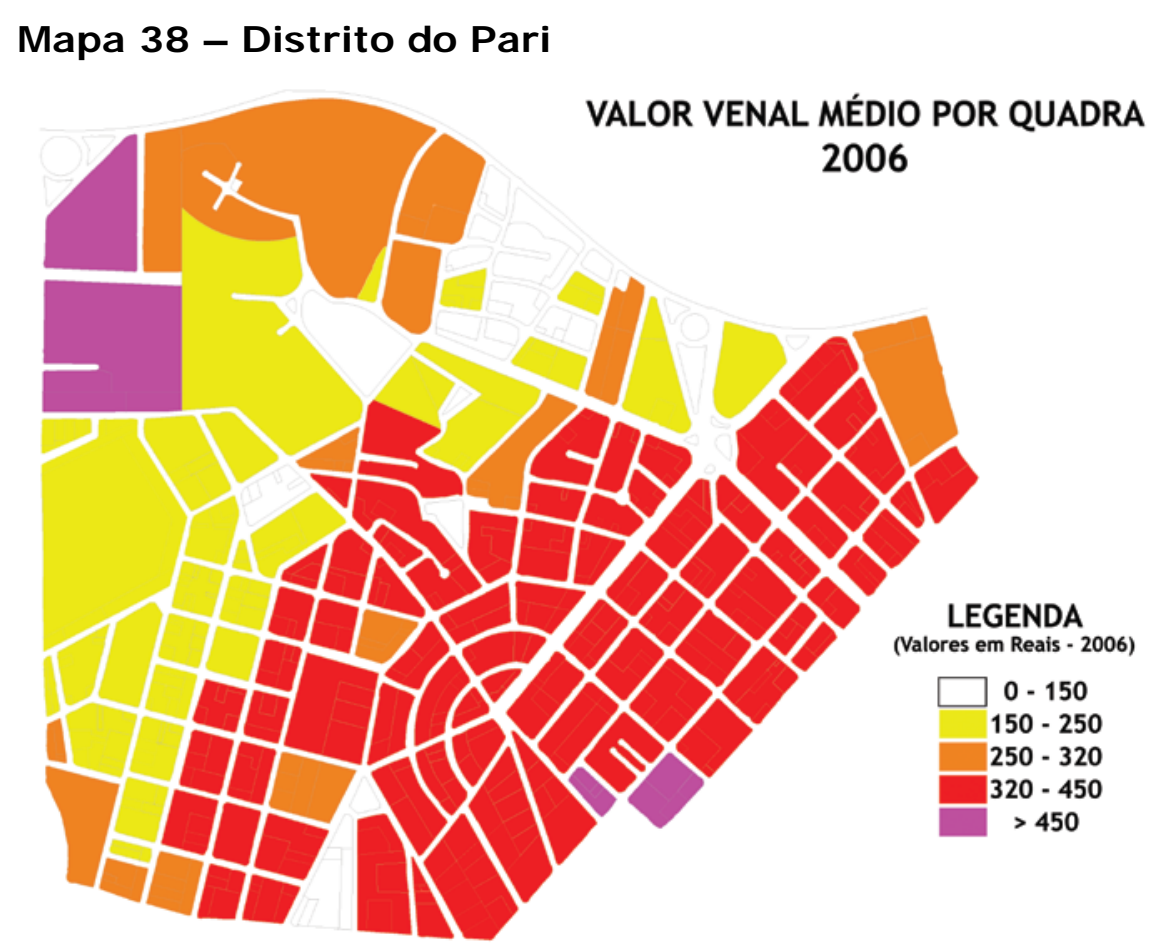

Podemos assegurar, depois da análise dos valores venais $/ \mathrm{m}^{2}$, que no distrito do Pari não houve mudanças significativas ou inesperadas, desde o estabelecimento da planta genérica de valores. Mesmo com a proximidade da Estação Armênia do metrô, não houve alteração diferencial do valor da terra na área, o que não era de se esperar, já que seria natural que a maior oferta de pontos, mais circulação de pessoas e de mercadoria trouxessem valorização aos imóveis da área.

Daí pode-se tirar três conjecturas:

1. O valor venal/ $m^{2}$ não teve grande alteração no período analisado que pudesse significar um dinamismo real da área. $O$ comportamento se manteve o mesmo durante 53 anos. 
2. As poucas mudanças ocorridas no Pari confirmam a tese de estagnação da área, ou seja, houve pouca valorização da terra entre 1953 e 2006.

3. Os mais altos e os mais baixos valores venais das diversas áreas são proporcionais aos praticados pelo mercado imobiliário. A Rua Silva Telles possui o preço do mercado imobiliário maior e o Canindé é a área mais desvalorizada.

Considera-se o período de 53 anos bastante significativo, já que durante o mesmo pôde-se assistir a metropolização da cidade e a implantação do capitalismo no Brasil, passando por fases políticas e estágios econômicos bem diversos.

As terras, no Pari, foram legalizadas num primeiro momento por antigos posseiros, moradores de chácaras - um modelo de ocupação muito comum ao redor do núcleo central do município - que posteriormente foram loteadas pelos herdeiros. Alguns desses deram nomes a várias ruas do bairro, como Pascoal Ranieri e Pascoal Malatesta, entre outros. Existem ainda herdeiros que mantêm a propriedade de vários imóveis, como Gustavo Bresser, João Boemer, Rodrigues dos Santos e Rodovalho da Fonseca. Desconhecemos, no entanto, a origem da posse, se por compra, por herança ou se eram empresários legitimadores de terras.

A história brasileira é a história da concentração de renda em mãos de uma pequena parcela da população e, consequentemente, da concentração da propriedade imobiliária e fundiária. E essa concentração pode ser confirmada e visualizada tanto em uma pequena parte da metrópole - como atestam os dados demonstrados neste trabalho quanto na maior parte da cidade.

A metrópole de São Paulo é o próprio reflexo da sua forma de ocupação, pois mostra nitidamente esse processo: a concentração da propriedade privada da terra nas mãos da classe dominante revela a separação entre ricos e pobres. Aqueles estabelecidos em áreas de maior valor imobiliário, ambientalmente mais qualificadas e de fácil acesso a toda a cidade; e estes empilhados em áreas de pouco interesse imobiliário. O fato de que $49 \%$ dos moradores do Pari pagam aluguel confirma a segregação de partes da cidade e a separação entre pobres e ricos. 
A renda da terra é um fator fundamental na criação e no desenvolvimento da segregação social que progressivamente se realiza no território urbano. Ela tem sido cada vez mais apropriada pelos grandes grupos monopolistas, que realizam uma fusão com o capital financeiro, o que, longe de resolver a contradição, intensifica-a.

O trabalho de Brito (2000) mostra como a urbanização paulistana foi um produto do processo de organização das atividades urbanizadoras em São Paulo. Uma presença empresarial bem estruturada, pautada numa ação conjunta, planejada e restrita a um relativamente pequeno número de empresários, articulava diferentes atividades econômicas, participava direta ou indiretamente da administração pública e concentrava a propriedade de uma razoável extensão territorial no entorno do núcleo urbano.

No que tange à postura das autoridades administrativas, elas sempre se mostraram coniventes com o processo de expansão da cidade e sua dotação material, uma vez que grande parte das terras disponíveis para o crescimento da área urbana pertenciam ao patrimônio da municipalidade e a ela incumbia o gerenciamento das mesmas, inclusive a concessão gratuita de aforamentos de enfiteuses ${ }^{17}$. A ela cabia, ainda, a concessão de privilégios relativos à implementação de infraestrutura e serviços urbanos.

O trabalho de Botelho (2005) mostra como, na produção do espaço urbano, os elementos de valorização do capital surgem na crescente integração entre o mercado imobiliário e o capital financeiro. O autor revela que as atividades de incorporação de imóveis correspondem a $12,1 \%$ das empresas, ocupando $8,7 \%$ do pessoal (20.271 pessoas ocupadas), com uma receita operacional líquida que corresponde a 36,5\% do total ( $R \$ 2.676 .5000 .000,00)$. O outro segmento ligado ao setor imobiliário, o de aluguel de imóveis, representa 54\% das empresas, ocupando $50,6 \%$ do pessoal ( 117.898 pessoas) e com uma receita

\footnotetext{
17 Enfiteuse, ou aforamento é um instituto jurídico de origem romana, derivado diretamente do arrendamento por prazo longo ou perpétuo de terras públicas a particulares, mediante o pagamento de um foro anual (vectigal). 
operacional líquida correspondente a $35,9 \%$ do total, o equivalente a $\mathrm{R} \$$ 3.625.900.000,00 (2004). Os dois segmentos, ligados ao setor imobiliário (incorporação e aluguel de imóveis), somados, representam um total de $\mathrm{R} \$$ 6.302.4000.000,00 de receita operacional liquida, ocupando 138.169 pessoas, $59,3 \%$ do pessoal da atividade de incorporação de imóveis. A movimentação da economia paulistana é extremamente dependente desse setor (BOTELHO, 2005).

Existem em São Paulo 420 mil imóveis desocupados (IBGE, 2000; SEHAB, 2004). Isso sem falar no mercado informal de aluguel explorado por proprietários de cortiços. O importante é constatar que imóveis existem, mas estão em mãos de poucos. A grande escassez de moradia nas grandes cidades é artificial. A escassez é manipulada. Como dizia Bolaffi (VILLAÇA, 1986), “o problema da falta de habitação é um falso problema". Habitações existem, o que não existe é a possibilidade de acesso a esses imóveis, já que não há renda suficiente para a aquisição. É a absolutização do direito de propriedade da terra com sua intangibilidade que permite guardá-la para valorização futura.

A desvalorização imobiliária do Pari pode ser comparada à de outros distritos da cidade e à evolução do preço do imóvel dentro do próprio distrito. Muitos dos entrevistados da pesquisa justificaram que mantêm seus imóveis fechados porque o imóvel sempre se valoriza, pois é justamente uma forma de o proprietário obter renda e se assegurar das intempéries da economia. O preço da terra sempre aumenta porque, como o processo da produção da cidade é contínuo, o valor social empregado continuamente se transforma em valor da terra.

\section{V - Lançamentos imobiliários}

A produção do espaço numa metrópole está sempre se reestruturando e esse processo contínuo não é homogêneo. O urbano está perpetuamente em movimento, e esse movimento está diretamente ligado aos interesses do mercado imobiliário e aos investimentos do Estado, que executa esses investimentos acatando as imposições da classe dominante, tanto técnicas quanto espaciais. Os bairros relegados 
(desprezados e esquecidos) pela classe dominante tornam-se estagnados. Aqueles que obtêm investimentos ou que são objeto de uma "renovação urbana" são chamados de "requalificados" ou se diz que "sofreram reconversão de uso". Esse constante processo de produção no/do espaço gera segregação, hierarquia e fragmentação socioespacial na metrópole, reafirmada na prática e na ideologia da ação do planejamento urbano. Assim, os bairros estagnados fazem parte da mesma reestruturação que renovou ou embelezou outros. Eles são frutos da mesma estratégia. É uma relação combinada, mas desigual. A reestruturação do/no espaço está diretamente ligada à propriedade privada disponível nesse espaço e a possibilidade de renda.

A propriedade fundiária e a renda (o pagamento de seu uso por parte de um terceiro) são fundamentos jurídicos e ideológicos da formação econômico-social capitalista.

A sociedade como um todo, paga uma parte do valor, que se valoriza no processo de produção social, um tributo à propriedade da terra, um tributo capitalista que equivale no seu patamar mínimo a juro de capital, e que é concretamente fração do trabalho excedente. Ou seja, como investimentos públicos em capital social estão constantemente definindo e redefinindo as localizações intra-urbanas, em termos de acessibilidade em geral, isso gera um ganho concreto dos proprietários de terras (SEABRA, 1988: 102-103).

Harvey sustenta que a apropriação da renda não é apenas necessária ao capitalismo, como os proprietários precisam assumir um papel ativo em busca da elevação da renda (HARVEY, 1990). O capitalismo ao se expandir, aglomerar e centralizar demanda do capital sua ação no espaço. O estágio do capitalismo contemporâneo é essencialmente urbano, ou como diz Lefèbvre:

O urbano caminha para uma totalidade sem jamais atingi-la, em que ele se revela totalizador por essência (a centralidade) sem que essa totalidade se efetue jamais (LEFÈBVRE, 2000: 156). 
Compreender como se dá a renda da terra urbana no capitalismo contemporâneo é essencial para entender como o mercado imobiliário atua no espaço.

As informações sobre lançamentos imobiliários tiveram como fonte os dados da Embraesp (Empresa Brasileira de Estudos Patrimoniais) e foram organizados pelo departamento de Informações (DIPRO) da Secretaria Municipal de Planejamento (SEMPLA/PMSP) em 2008.

Os órgãos públicos não registram, acompanham ou analisam as informações sobre o mercado imobiliário privado. Eles organizam apenas seus próprios dados de promoções habitacionais para atender a população de menor poder aquisitivo. Assim, as nomenclaturas utilizadas são, na sua maioria, definidas a partir de análises do setor privado. Adotamos a definição dada pelo produtor de dados, a Embraesp. Trata-se de instituição privada que coleta de forma sistemática, desde 1977, os folhetos publicitários, anúncios e informações dos corretores referentes aos lançamentos imobiliários.

O critério utilizado pela Embraesp para definir a data do lançamento imobiliário é o momento de início do empreendimento, evidenciado pela sua publicidade seja nos meios de comunicação, seja por meio eletrônico ou pela distribuição de material impresso (Embraesp, 2007). Os lançamentos são divididos entre residenciais e não residenciais. Para o presente trabalho interessa apontar unicamente os lançamentos residenciais, já que não houve lançamentos não residenciais na área. Houve apenas reformas de edificações não residenciais.

Os lançamentos residenciais no município de São Paulo (tabela 18) podem mostrar o comportamento do mercado imobiliário da construção privada. O Pari nos últimos 10 anos teve 2 lançamentos imobiliários. Um em 1999, localizado na Rua Sacramento, no Alto do Pari, de um apartamento por andar (foto 19), e outro em 2001, um conjunto com dois edifícios, localizado na Rua Padre Vieira, $n^{\circ}$ 62, de dois dormitórios (foto 19). De todos os subdistritos do Centro, o Pari e o Brás são os que tiveram menos lançamentos imobiliários, dois cada um. 
Tabela 18 - Número de lançamentos residenciais verticais - MSP - Subprefeituras (centrais) Distritos Municipais (centrais) - 1992-2007

\begin{tabular}{|c|c|c|c|c|c|c|c|c|c|c|c|c|c|c|c|c|c|}
\hline Unidades & 1992 & 1993 & 1994 & 1995 & 1996 & 1997 & 1998 & 1999 & 2000 & 2001 & 2002 & 2003 & 2004 & 2005 & 2006 & 2007 & $\begin{array}{l}\text { Total } \\
\text { Geral }\end{array}$ \\
\hline MSP & 148 & 301 & 369 & 382 & 343 & 319 & 246 & 236 & 315 & 249 & 267 & 274 & 237 & 261 & 255 & 307 & 4.509 \\
\hline Mooca & 11 & 15 & 27 & 24 & 24 & 19 & 15 & 24 & 24 & 17 & 15 & 19 & 23 & 14 & 17 & 28 & 316 \\
\hline Água Rasa & 2 & 3 & 10 & 4 & 6 & 5 & 5 & 5 & 7 & 4 & 1 & 4 & 5 & 6 & 1 & 11 & 79 \\
\hline Belém & 1 & 1 & 1 & - & 2 & - & - & 2 & - & 1 & - & 2 & - & - & 2 & 2 & 14 \\
\hline Brás & - & 1 & - & - & - & 1 & - & - & - & - & - & - & - & - & - & - & 2 \\
\hline Moóca & 1 & 2 & 5 & 5 & 4 & 3 & 2 & 8 & 7 & 4 & 5 & 3 & 8 & 3 & 4 & 9 & 73 \\
\hline Pari & - & - & - & - & - & - & - & 1 & - & 1 & - & - & - & - & - & - & 2 \\
\hline Tatuapé & 7 & 8 & 11 & 15 & 12 & 10 & 8 & 8 & 10 & 7 & 9 & 10 & 10 & 5 & 10 & 6 & 146 \\
\hline Sé & 10 & 10 & 22 & 12 & 19 & 15 & 14 & 15 & 20 & 11 & 13 & 22 & 16 & 18 & 18 & 23 & 258 \\
\hline Bela Vista & 1 & 2 & 7 & 3 & 9 & - & 3 & 1 & 5 & 3 & - & 2 & 5 & 2 & 2 & 2 & 47 \\
\hline Bom Retiro & - & - & - & - & - & - & - & - & - & - & - & 1 & - & - & 2 & 3 & 6 \\
\hline Cambuci & 1 & 1 & - & - & 1 & 2 & - & 5 & 1 & 1 & - & 2 & 1 & 1 & - & 1 & 17 \\
\hline Consolação & 3 & 2 & 4 & 4 & 2 & 2 & 6 & 5 & 5 & 2 & 5 & 4 & 3 & 4 & 2 & 1 & 54 \\
\hline Liberdade & 1 & 3 & 5 & 3 & 3 & 5 & 4 & - & 5 & 3 & 5 & 6 & 4 & 4 & 4 & 10 & 65 \\
\hline República & 1 & - & 1 & - & 1 & - & - & 1 & 3 & - & 1 & 2 & - & 2 & 1 & 1 & 14 \\
\hline Santa Cecília & 3 & 2 & 5 & 2 & 3 & 6 & 1 & 3 & 1 & 2 & 2 & 5 & 3 & 5 & 7 & 5 & 55 \\
\hline Sé & - & - & - & - & - & - & - & - & - & - & - & - & - & - & - & - & - \\
\hline
\end{tabular}

Os dados de lançamentos imobiliários verticais residenciais no distrito do Pari são irrisórios em comparação a muitos distritos da capital. Em relação a lançamentos comerciais a situação é mais homogênea entre todos os distritos centrais do município (Tabela 19)

Tabela 19 - Número de Lançamentos Verticais Comerciais - MSP - Subprefeitura - Distrito $1992-2007$

\begin{tabular}{|c|c|c|c|c|c|c|c|c|c|c|c|c|c|c|c|c|c|}
\hline Unidades & 1992 & 1993 & 1994 & 1995 & 1996 & 1997 & 1998 & 1999 & 2000 & 2001 & 2002 & 2003 & 2004 & 2005 & 2006 & 2007 & $\begin{array}{l}\text { Total } \\
\text { Geral }\end{array}$ \\
\hline MSP & 15 & 17 & 21 & 29 & 44 & 49 & 39 & 17 & 17 & 18 & 20 & 13 & 13 & 10 & 11 & 6 & 339 \\
\hline Moóca & 1 & - & - & - & 1 & 6 & - & - & - & 2 & - & 1 & - & - & 2 & - & 13 \\
\hline Água Rasa & - & - & - & - & - & 1 & - & - & - & - & - & - & - & - & - & - & 1 \\
\hline Belém & - & - & - & - & - & - & - & - & - & - & - & - & - & - & - & - & - \\
\hline Brás & - & - & - & - & - & - & - & - & - & - & - & - & - & - & - & - & - \\
\hline Moóca & - & - & - & - & - & 1 & - & - & - & - & - & - & - & - & 1 & - & 2 \\
\hline Pari & - & - & - & - & - & - & - & - & - & - & - & - & - & - & - & - & - \\
\hline Tatuapé & 1 & - & - & - & 1 & 4 & - & - & - & 2 & - & 1 & - & - & 1 & - & 10 \\
\hline Sé & - & 1 & 2 & 4 & 5 & 4 & 4 & 1 & 1 & 3 & 6 & 1 & 1 & - & 1 & - & 34 \\
\hline Bela Vista & - & 1 & - & 1 & 2 & 1 & 1 & 1 & - & - & 4 & 1 & 1 & - & - & - & 13 \\
\hline Bom Retiro & - & - & - & 1 & - & - & - & - & - & - & - & - & - & - & - & - & 1 \\
\hline Cambuci & - & - & - & - & - & - & - & - & - & - & - & - & - & - & - & - & - \\
\hline Consolação & - & - & 2 & - & 1 & - & 1 & - & - & 1 & 2 & - & - & - & 1 & - & 8 \\
\hline Liberdade & - & - & - & - & - & - & 1 & - & - & 1 & - & - & - & - & - & - & 2 \\
\hline República & - & - & - & - & - & - & - & - & - & - & - & - & - & - & - & - & - \\
\hline Santa Cecilia & - & - & - & 1 & 2 & 2 & 1 & - & 1 & 1 & - & - & - & - & - & - & 8 \\
\hline Sé & - & - & - & 1 & - & 1 & - & - & - & - & - & - & - & - & - & - & 2 \\
\hline
\end{tabular}

Fonte: Embraesp/ SEMPLA/Dipro 
É necessário dizer que, entre 1998 e 2007, todos os distritos registraram uma diminuição dos lançamentos imobiliários. Mesmo a produção de habitação popular executada pelo Poder Público despertou interesse na área só há poucos anos. Até 2004, a CDHU promoveu a incorporação de dois conjuntos habitacionais para população de baixa renda e mais 3 conjuntos até 2008, relatados no item residencial página 91. A COHAB implantou um conjunto habitacional, com aluguel social, para catadores de papel e pessoas de quase nenhuma renda. São nessas áreas rejeitadas pelo mercado imobiliário privado e nas áreas públicas situadas em regiões desvalorizadas que a população trabalhadora pobre pode se instalar.

Um dos fatores que dificultam a incorporação no bairro é a conformação dos lotes, de dimensão muito pequena. Nos loteamentos, os terrenos foram retalhados o máximo possível para pequenas habitações populares. Isso dificulta a incorporação, já que é complicado conseguir acordo de todos os moradores para abarcar uma área apropriada para incorporação. Além disso, em algumas partes do distrito as configurações das quadras não obedecem às formas mais habitualmente usadas na cidade, a forma quadrada ou retangular. Há várias quadras com desenhos arredondados ou hexagonais e outras formas não definidas.

A valorização imobiliária está relacionada aos interesses do capital. Na hierarquia desse mercado, o essencial é a reprodução do capital, e não a valorização dos imóveis; em vista disso, o Pari permanece relegado a segundo plano. O mercado imobiliário privado para habitação de interesse social não consegue atender a maioria da população dentro das alternativas legais nas metrópoles, o que mostra a inoperância da autoregulação de mercado. $O$ fato é que nessas condições o urbanismo não atua para resolver os problemas dos necessitados, mas para contribuir na construção de um mercado imobiliário capitalista, de relações de subordinação, de repressão, ou de segregação no espaço urbano. E, enquanto perdurar essa opção política pelos mais abonados, a cidade não mudará de cara.

Para o setor imobiliário a imobilidade de grande capital em estoque de terras pode ser um obstáculo ao desenvolvimento do capitalismo, entretanto, inviabiliza a acumulação de capital no interior deste, impossibilitando que o próprio capital se reproduza. Nesse processo de 
expansão da área construída, na estratégia para o enfrentamento da alta dos preços nas áreas mais "nobres" da cidade, é fundamental o papel dos promotores/incorporadores imobiliários, criando novas necessidades, que se materializam na diferenciação espacial. No Pari, está se insinuando uma mudança, já que existem grandes áreas ocupadas por transportadoras e indústrias que podem deixar esses locais e se localizar em lugares menos valorizados. Essa mudança se dará se houver interesse por parte do mercado imobiliário.

O mercado imobiliário ainda não voltou os olhos para o Pari porque, apesar de bem localizado, o bairro é maculado por situar-se na Zona Leste. Mas alguns indícios têm demonstrado que o rótulo de pobre imposto a essa área da cidade será passada para trás, o que certamente despertará o interesse do mercado assim que ele tiver a garantia de um retorno seguro.

\section{2.g - A história da ação do Poder Público sobre o espaço}

I - Legislação do uso e ocupação do solo

O espaço urbano é fruto da legislação de Uso e Ocupação do Solo e demais posturas municipais, tais como o código de obras e as leis de parcelamento do solo. É basicamente a legislação de Uso e Ocupação do Solo que produz a paisagem urbana, moldando a volumetria do espaço e estabelecendo a diversidade de uso.

A lei no. 13.885/04, o Plano Regional Estratégico do Município de São Paulo, estabelece o zoneamento - lei de Uso e Ocupação do Solo de cada Subprefeitura. O zoneamento serve para estabelecer as regras e parâmetros de uso e ocupação do lote: as características de aproveitamento, dimensionamento e ocupação do lote, além de estabelecer os usos permitidos em cada lote. O zoneamento estabelece, então, a intensidade ou volume $\left(\mathrm{m}^{3}\right)$ a ser ocupado no lote e seu respectivo uso. No entanto, como sintetiza Villaça, 
A verdade que o zoneamento procura ocultar é que sua finalidade é (e sempre foi) proteger o meio ambiente e os valores imobiliários de interesse (econômico ou de moradia) da minoria mais rica, contra processos que o degradem (VI LLAÇA, 2005: 46).

\section{Mapa 39 - Uso e Ocupação do Solo (lei $n^{\circ} .13 .885 / 04$, anexo}

\section{ao Livro XXV, mapa 04)}

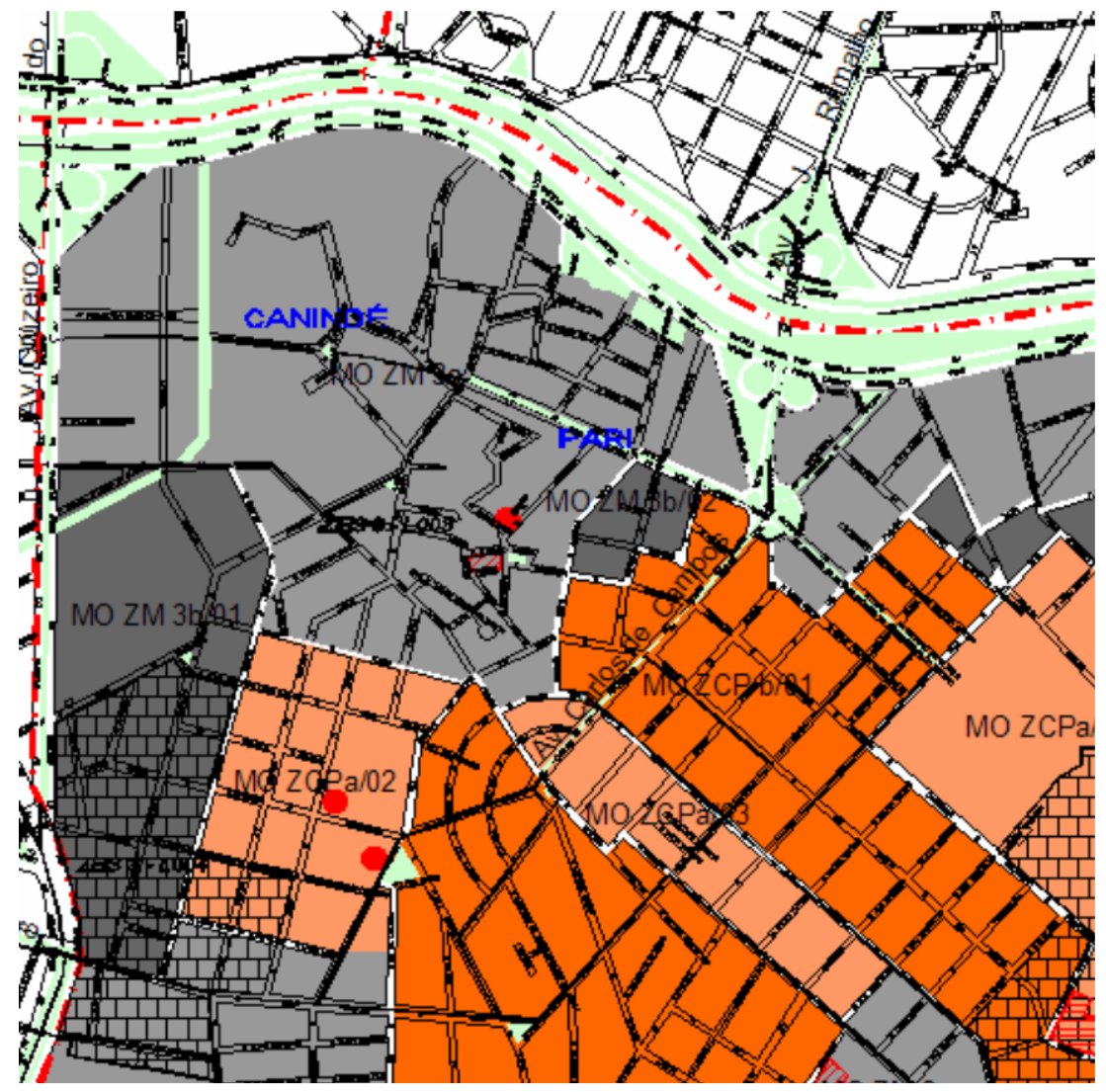

PRE - lei $n^{\circ} .13 .885 / 04$

Uso e Ocupação do Solo

Zona Mista de alta densidade

$\mathrm{ZM}-3 \mathrm{~b}$ Zona Mista de alta densidade

ZCP-a Zona de centralidade polar Zona de centralidade polar

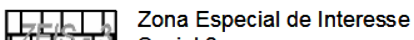
Social 3

Zona Especial de Preservação Cultural (área)

Zona Especial de Preservação Cultural (imóvel)

O distrito do Pari pertence à subprefeitura da Moóca e está inserido no livro XXV do PRE (lei no. 13.885/04) ( Mapa 39). Essa área contém as zonas mais diversificadas e de maior densidade da nova legislação de zoneamento. $70 \%$ do distrito está localizado em zonas de uso ZM-3a e 
ZM-3b, zonas mistas de alta de densidade, com coeficiente básico de 1,0 e 2,0 respectivamente e coeficiente máximo de 2,5 e 3,0, com diversidade de uso médio, dependendo da categoria da via para se implantar usos não residenciais; também, no perímetro do distrito estão inseridas as zonas ZCP-a e ZCP-b - zonas de centralidade polar -, nos quais os coeficientes básicos são 1,0 e 2,0, atingindo coeficientes máximos de 2,5 e 4,0 (coeficiente máximo do município). Essas duas zonas são as que têm legislação mais permissivas e de maior densidade de população, apresentando o maior dinamismo e as maiores disputas no uso e ocupação do solo do município (Mapa 40).

\section{Mapa 40 - Mapa com os dois zoneamentos}

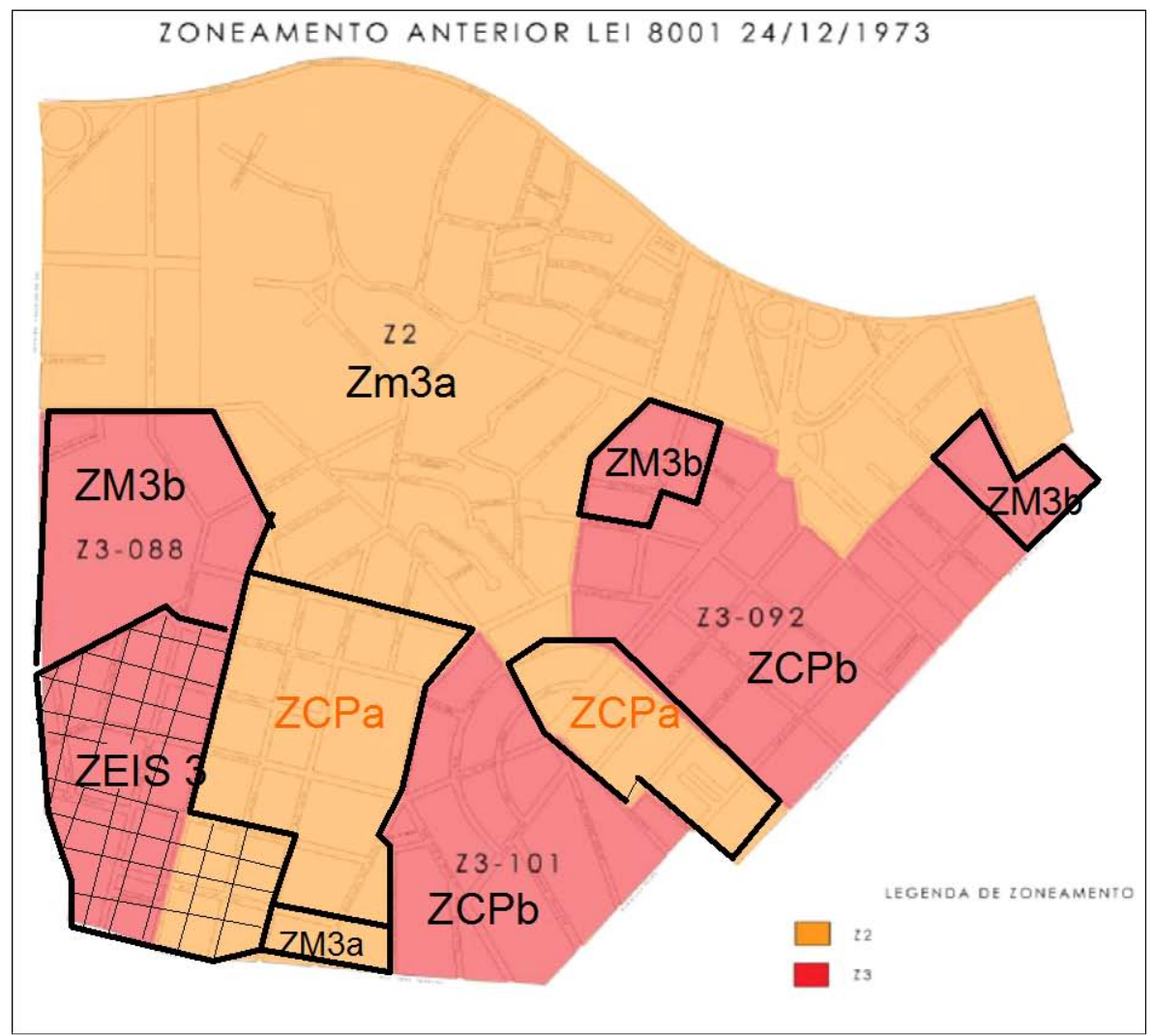

PRE - Lei 13.885/04

ZM3a - Mista de alta densidade

ZM3b - mista de alta densidade

ZCPa - centralidade polar

$\mathrm{ZCPb}$ - centralidade polar mais permissiva

ZEIS 3- Especial de Interesse social

Numa comparação com a lei anterior, constatamos não haver grandes mudanças, pois o zoneamento anterior do distrito inteiro era Z2 e Z3, ou seja, área de densidade média e média alta, que podia atingir o 
coeficiente máximo de 2,5 a 4, dependendo da taxa de ocupação. A comparação é mostrada no mapa 41. A lei anterior também permitia vários usos, além de não haver restrição nas vias, e nem por isso a legislação provocou uma ocupação mais densa.

Além dessas zonas, a novidade da lei de uso e ocupação em vigência está na introdução das Zonas Especiais. No Pari foram introduzidas a ZEIS-3 (Zona Especial de Interesse Social), onde há concentrações de cortiços ou de terrenos e edificações subutilizadas, situadas em áreas dotadas de infraestrutura, e propostas de ZEPEC (Zona Especial de Proteção Cultural), as antigas Z8-200, áreas e imóveis tombados.

$\mathrm{Na}$ ZEIS-3 o coeficiente de aproveitamento máximo é 4, com isenção do pagamento de outorga onerosa para o potencial construtivo excedente ao coeficiente básico. No distrito, existem duas ZEIS-3: uma grande área entre a Avenida Cruzeiro do Sul e a Rua Tiers e entre a Rua J oão Teodoro até as ruas Conselheiro Dantas e Vidal de Negreiros. Essa área é repleta de cortiços e usos incômodos, como oficinas e bares. Mas é uma área que a $\mathrm{CDHU}$ tem aproveitado para implantar diversos conjuntos habitacionais de interesse social. Já foram implantados 4 conjuntos, desde 2002, e há mais um em implantação (ver item sobre uso residencial); a outra ZEIS-3 é um lote na Rua das Olarias com a Rua Araguaia, justamente o lote onde foi instalado o edifício Olarias, pela COHAB, para a Associação dos Catadores de Papel (ver item sobre uso residencial). A ZEIS-3 realmente pode mudar a paisagem dessa área do distrito do Pari e estimular a substituição de cortiços por habitação popular, o que timidamente vem acontecendo.

As ZEPECs (mapa 39) constantes na referida lei são todas "propostas" e não estão ainda consolidadas pelo COMPRESP - órgão do município que cuida do tombamento de imóveis. Essas propostas são: a Igreja de Santo Antônio do Pari, de 1911; a Igreja de Nossa Senhora Aparecida, localizada no morro do Pari, de 1927 (Foto 27); o edifício industrial (antiga fábrica de panelas) situado na esquina das ruas Tiers e Hannemann, 335, lote 34; e toda a área do morro do Pari (Foto 36) que agrega as quadras 27, 41, 96, 101 e 102, do setor fiscal 017, proposta em razão das formas irregulares das quadras e da ocupação atípica, com 
ruas estreitas, pequenas vilas, casinhas geminadas em lotes exíguos, sem recuo frontal e cortiços confrontando com casas de padrão médio.

\section{Foto 36 - I greja Nossa Senhora Aparecida e morro do Pari}
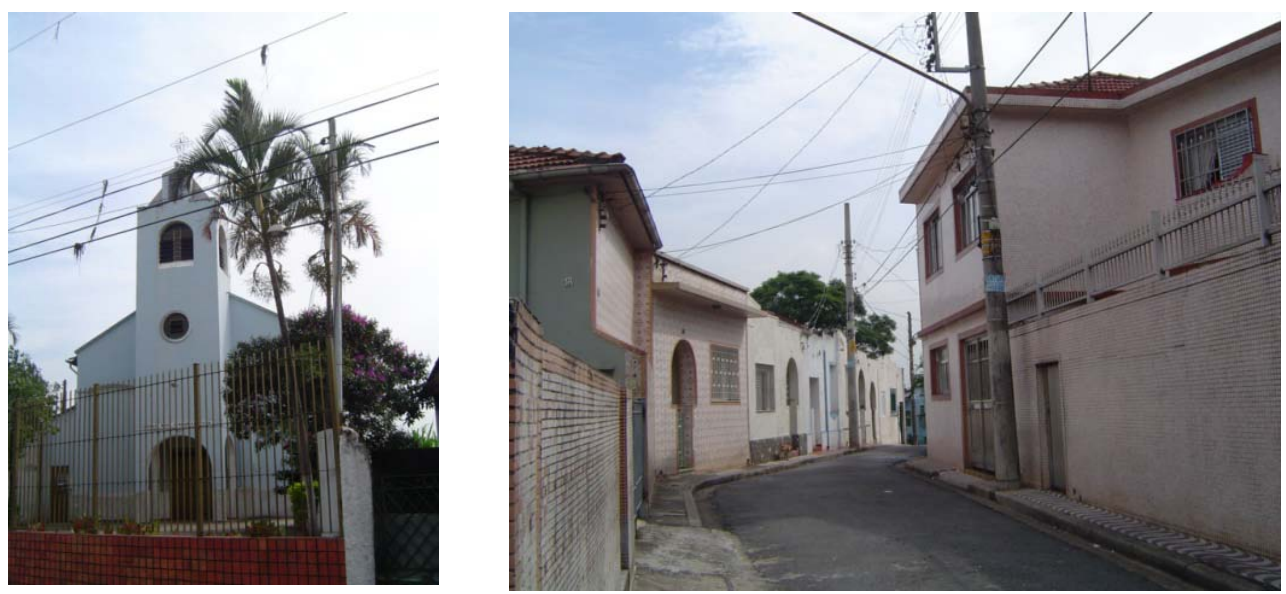

As propostas quanto ao sistema viário podem ser visualizadas nos mapas de Rede Estrutural Hídrica Ambiental (Mapa 41) e Sistema Viário Estrutural (Mapa 43). Há proposta de abertura de via e de caminho verde que prossegue pela Avenida Bom Jardim chegando até a Avenida Cruzeiro do Sul, cortando as quadras onde hoje estão instalados a SPTrans e o CMTC Clube.

\section{Mapa 41 - Rede Estrutural Hídrica Ambiental (lei $\mathbf{n}^{\circ}$} 13.885/ 04, anexo ao Livro XXV, mapa 01)

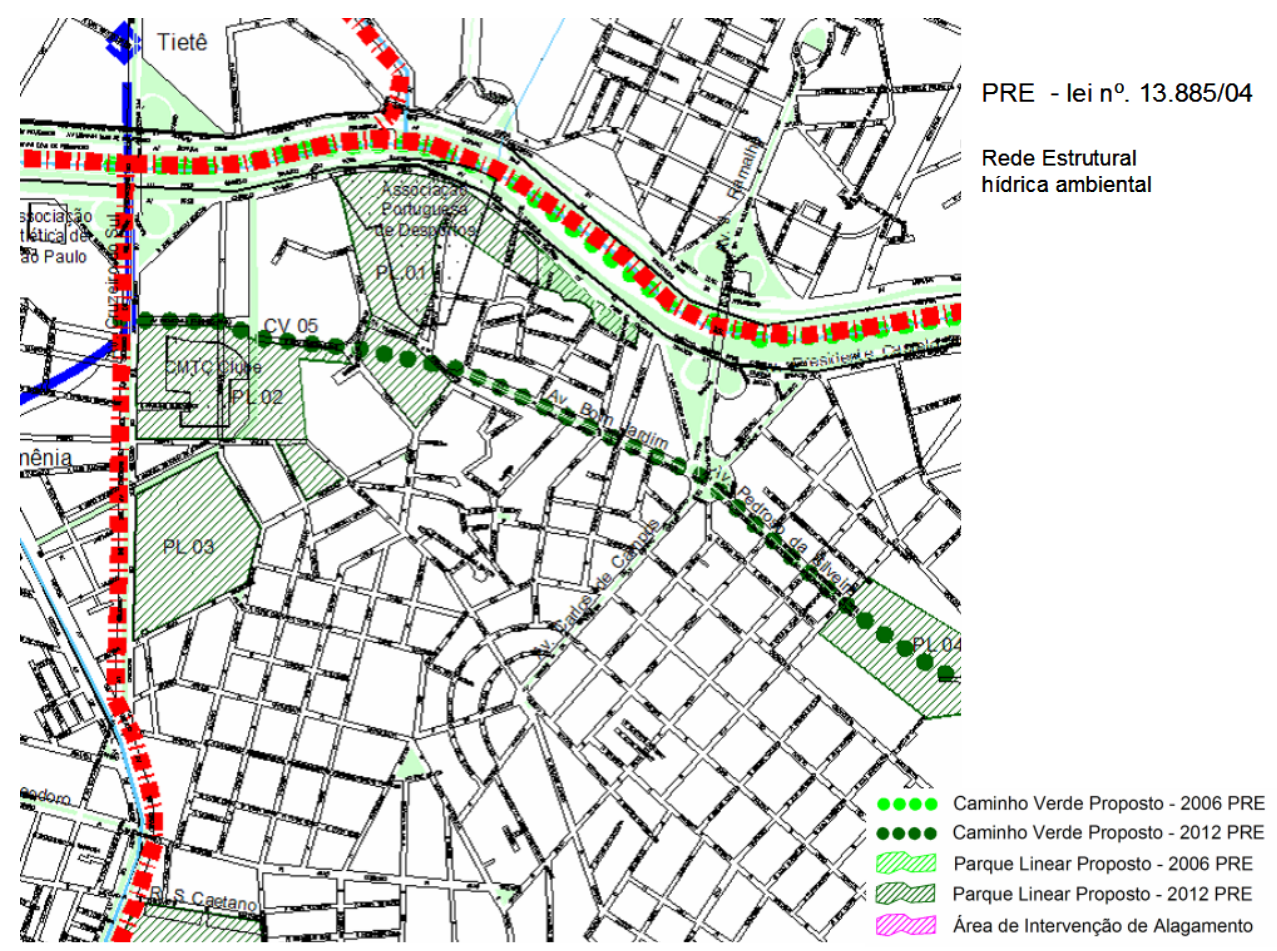


Quanto ao Transporte Público, no mapa de Rede Estrutural de Transporte Público (mapa 43) há a proposta de:

- Passa Rápido ${ }^{18}$ (2006) nas vias: Avenida Cruzeiro do Sul e Rua J oão Teodoro.

- Passa Rápido (2012) pela via (proposta) de continuação da Avenida Bom Jardim.

Mapa 42 - Rede Estrutural de Transporte Público (lei $\mathbf{n}^{\circ}$ 13.885/ 04, anexo ao Livro XXV, mapa 03)

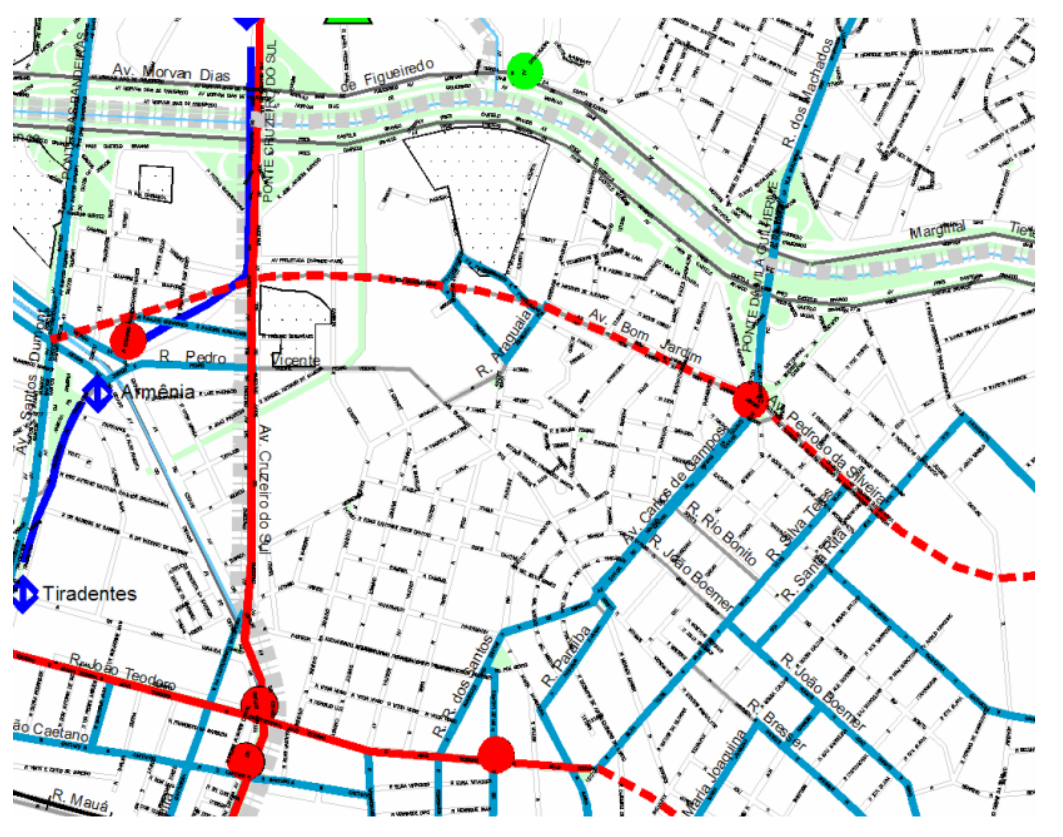

PRE - lei no. 13.885/04

Rede Estrutural de

Transporte Público

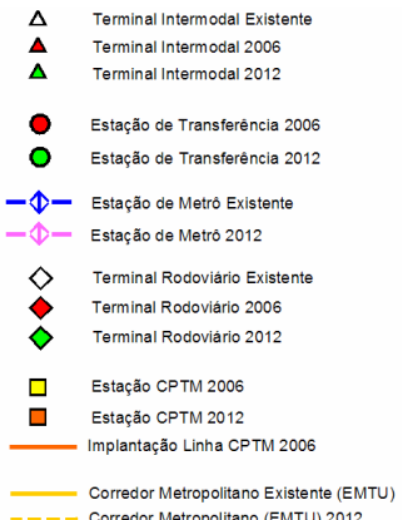

$=--$ Corredor Metropolitano (EMTU) 2012

Passa Rápido Existente

- Passa Rápido 2006

- - - Passa Rápido 2012

- Programa Via Livre 2006
---- Programa Via Livre 2012

- Programa Via Livre 2006 - nas vias: Silva Telles,

Santa Rita, Carlos Campos, Paraíba e Rodrigues dos Santos. E ruas Araguaia, Pascoal Ranieri e da Piscina.

\footnotetext{
${ }^{18}$ Passa Rápido é o nome dado aos corredores na gestão 2000-2004, ou seja, vias com sistema físico especial para ônibus.

19 Programa Via Livre - é o programa operacional para privilegiar ônibus em algumas vias adotado na gestão 2000-2004.
} 


\section{Mapa 43 - Sistema Viário Estrutural (lei $n^{\circ} .13 .885 / 04$, anexo ao Livro XXV, mapa 02)}

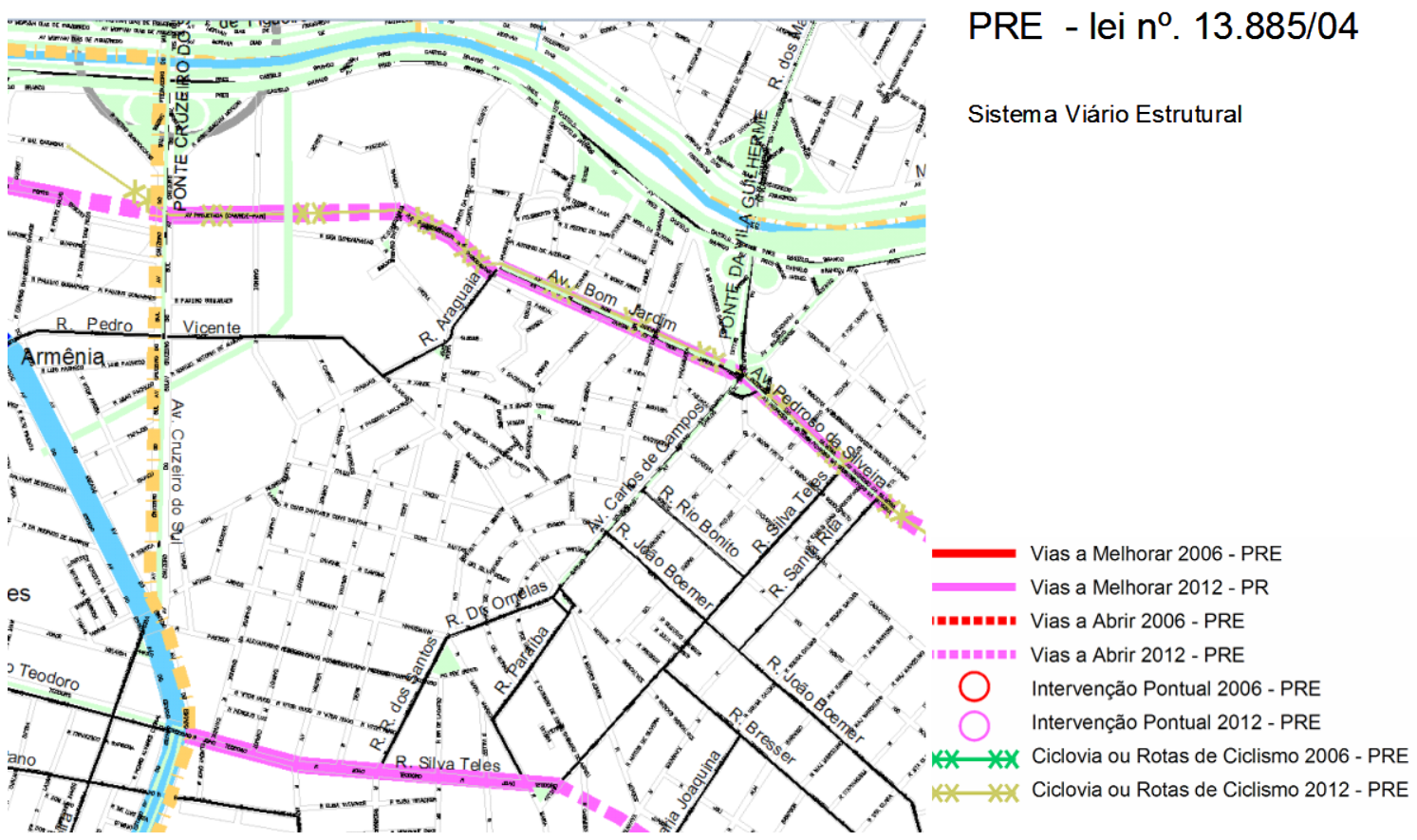

Há, ainda, área para ser revitalizada (mapa 44) - AlU,

Área de Intervenção Urbanística - , que ocupa a parte leste do distrito.

Essa área é estabelecida pela seção VI, artigo 49, 51, 52 e 53 do livro $\mathrm{XXV}$ :

\section{Seção VI - Das Áreas de Intervenções Urbanas}

Art. 49 - As Áreas de Intervenção Urbana da Subprefeitura da Moóca, criadas neste Plano Regional, são aquelas constantes do Quadro 05 e do Mapa 05 integrantes deste Livro e têm como diretrizes:

I. implantar parques lineares;

II. implantar áreas verdes de recreação e lazer;

III. viabilizar áreas de retenção de águas pluviais para auxiliar o sistema de drenagem;

IV. manter a permeabilidade do solo existente, garantindo as condições de drenagem e absorção das águas pluviais;

V. ampliar as áreas permeáveis nos fundos de vale;

VI. valorizar a paisagem, privilegiando espaços de uso público;

VII. criar e qualificar espaço de uso público destinado ao lazer da população residente nas imediações dos parques lineares e ZEPAM's;

VIII. implantar ciclovia;

IX. transformar a calçada em caminho verde para pedestres, com complementação da arborização;

$X$. promover espaços de uso público, viabilizando integração com calçadas e praças para as áreas das estações de metrô;

XI. criar e qualificar os espaços públicos no entorno das estações do metrô;

XII. revitalizar e manter as praças públicas;

XIII. manter com tratamento adequado as calçadas, avaliando, inclusive, a arborização existente, visando ao conforto térmico e à atenuação dos ruídos; 
XIV. implantar habitações adequadas para abrigar os moradores da favela e cortiços:

$X V$. implantar habitações de interesse social e seus equipamentos de uso coletivo, permitindo a recuperação das áreas atuais ocupadas por favelas e cortiços.

Art. 51 - A Área de Intervenção Urbana Projeto Estratégico Pari-Brás tem como objetivo uma renovação completa do setor a partir da implantação da nova ligação viária que circunda o nó central criando nova rótula a nordeste, a desembocar na região da Luz, conforme legislação em vigor.

Art. 52 - A Área de Intervenção Urbana Projeto Estratégico Pari-Brás tem como diretrizes:

I. Introdução de novos equipamentos públicos e de uso coletivo, destacandose a implantação de um parque linear público de apoio às residências.

II. Promover a recuperação dos edifícios presentes no setor, tanto residenciais quanto comerciais, industriais e de serviços.

III. Incentivar o uso residencial aproveitando a infra-estrutura instalada conforme indicação das Zeis-3, no entorno do parque proposto.

IV. Implantar equipamentos de saúde, educação e cultura de apoio à população moradora.

V. Efetuar estudos para a adequada abertura da ligação viária e seu entorno, incluindo a implantação de volumetria, recuos adequados, vagas de estacionamento e espaços de convívio.

Art. 53 - A Área de Intervenção Urbana Projeto Estratégico Rua Santa Rita / Avenida Guilherme Cotching tem como objetivo uma readequação dos espaços resultantes da nova avenida garantindo a criação de áreas verdes do parque linear.

Art. 54 - A Área de Intervenção Urbana Projeto Estratégico Rua Santa Rita / Avenida Guilherme Cotching tem como diretriz promover a reabilitação das quadras adjacentes criando espaços de convívio, arborização e cultura.

Cabe ressalvar que os procedimentos de implantação das diretrizes estabelecidas para as Áreas de Intervenção Urbana serão regulamentados por lei específica, ou seja, ainda não foram regulamentadas. As diretrizes existem, mas não podem ainda ser implementadas.

Mapa 44 - Desenvolvimento Urbano (lei $n^{\circ} 13.885 / 04$, anexo ao Livro XXV, mapa 05)

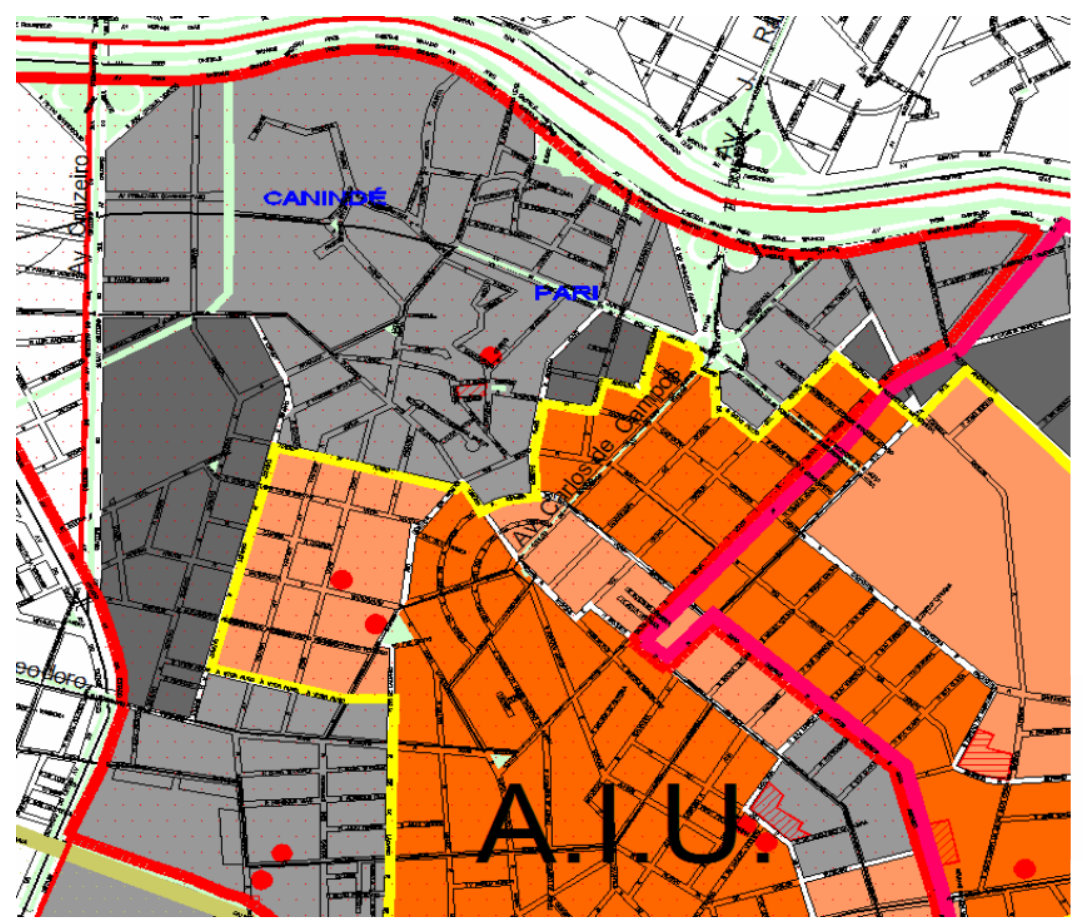

PRE - lei nº $13.885 / 04$

Desenvolvimento Urbano

AREA DE INTERVENCROOO UFGANA

wU. Area de intervençto Utbana

sau Projevo Estrategloo de intervencto uroan

eue Operaçâto Uibana Consordada Centro

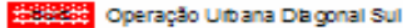

Figrog: Operacăo U vana Celso Garce 
Apresentado o zoneamento atual do distrito do Pari, vale enfatizar que a legislação permite transformações marcantes na área. A fisionomia do bairro só poderá se alterar se o mercado imobiliário tiver interesse em investir na área, caso contrário o bairro continuará no processo de estagnação urbana. A legislação de uso e ocupação do solo é bastante estimulante para o adensamento e a diversidade de usos. Os usos sempre foram bastante diversificados e sempre apresentaram uma convivência harmoniosa com os moradores. O adensamento não foi mais intensificado porque não houve interesse do mercado imobiliário. Tentamos entrevistar a Embraesp (Empresa Brasileira de Estudos de Patrimônio) e enviamos vários correios eletrônicos com perguntas sobre o distrito do Pari e não obtivemos resposta. A impressão que fica é de que essa parte da cidade não existe para determinados segmentos da sociedade.

As ações dos governos locais, essencialmente o Planejamento Urbano (urbanismo), com a legislação de uso e ocupação do solo e a regulamentação do código de edificações, se viabilizam como políticas em favor de interesses imobiliários.

\section{II - Investimentos públicos}

Os investimentos públicos também são sintomáticos desse descaso para com o distrito. O último investimento, em sistema viário ou de infraestrutura, realizado na gestão de 1991 a 1994, foi a abertura da Avenida Bom Jardim, paralela à Marginal Tietê, que liga o Canindé ao norte da Rua Silva Telles ou a Avenida Carlos Campos (importante penetração para a Vila Guilherme). Essa via cortou vários imóveis, que não foram ainda integrados à paisagem urbana. O remanescente de um desses imóveis resultou em um edifício novo na Avenida Bom Jardim, com porte para estabelecer uma concessionária de veículos, mas por enquanto está desativado. Parece que não houve interessados em Ihe dar uma função.

Os investimentos numa determinada área não precisam necessariamente ser em vias ou construção específica. Podem-se criar programas sociais, como foi o caso, na gestão 2000-2004, com os 
catadores de papel, que são em grande número do distrito. Muda a gestão, rompe-se com tudo o que existia na administração anterior por não se tratar do mesmo partido político. Não existe Política Urbana como Política de Estado. Essa falta de continuidade administrativa em programas sociais só penaliza a população. Pode-se, também, investir em novas linhas de ônibus, intensificando a circulação pelo interior do bairro sem, necessariamente, aumentar o número de ônibus. Poderíamos enumerar propostas para cada setor. É evidente, no entanto, que o mercado imobiliário não se interessa pelo Pari, e que o Poder Público, porta-voz da classe dominante, também não vê razão para tomar a iniciativa. 


\section{A estagnação do Pari e a estrutura urbana}

\section{3.a. A estagnação na estrutura urbana paulistana}

A estagnação de um bairro em uma metrópole está inserida no movimento de sua própria reestruturação, que se dá continuamente, e na estrutura da metrópole. É preciso compreender que sentidos ela pode ter e qual a sua relação com outros fenômenos urbanos.

Assim como o movimento, há outros elementos constituintes do espaço que estão estreitamente ligados à questão da estagnação e do movimento da cidade, como segregação, diferença, desigualdade $\mathrm{e}$ estrutura.

Por segregação entendemos o ato ou efeito de segregar(-se); afastamento, separação voluntária.

Nos estudo sociológicos, a segregação é:

a separação, por razões sociais, de um grupo em relação a outro, em geral perpetuando condições de desigualdade e opressão social. Na maioria das vezes, refere-se a distribuições de natureza física, como a segregação de bairros ou escolas, que concentram indivíduos de diferentes raças, etnias, classes sociais ou religiões em territórios diferentes, ou em ambientes de trabalho segregados, onde homens e mulheres realizam tipos claramente diferentes de trabalhos. [A segregação pode ocorrer] Quando grupos desprivilegiados são concentrados em áreas das quais é difícil escapar porque não dispõem de recursos financeiros para tanto, são limitados pela discriminação ou proibidos de assim proceder pela lei vigente - essas áreas onde moram são conhecidas como guetos (J ONHSON, 1983).

Portanto, entendemos a segregação como a auto-separação de grupos privilegiados do resto da cidade, para manter vantagens ambientais, 
urbanísticas e/ou separação social e cultural. Essa auto-segregação é uma opção desses próprios grupos, e não uma segregação imposta pela sociedade.

As áreas centrais paulistana não acompanharam as transformações da metrópole devido à combinação de grande empobrecimento e decadência. O Pari, que faz parte das áreas centrais, sofreu essa mudança de forma bastante acentuada e visível frente ao curso de produção da cidade. A segregação é o processo de um ostensivo distanciamento da formação democrática do espaço urbano, uma vez que funciona para estigmatizar, controlar e excluir aqueles que acabaram de forçar seu reconhecimento como cidadãos, com plenos direitos de se envolver na construção do futuro e na paisagem da cidade (CALDEI RA, 2000).

No movimento de reestruturação da cidade, a segregação cria desigualdades espaciais e diferenças do e no espaço. O espaço segregado se aparta dos seus diferentes, fraciona-se e cria porções fragmentadas e homogêneas com determinadas hierarquias (LEFĖBVRE, 1999).

LOJ KINE afirma que a segregação urbana - a separação da periferia em relação ao núcleo central - está vinculada à renda fundiária. As áreas centrais são a parte da cidade cada vez menos reservada às sedes de grandes empresas, as únicas que têm o poder de apropriar-se dessa vantagem de localização são o centro de negócios da cidade (LOJ KINE, 1981).

A segregação espacial é o resultado da divisão social do trabalho, da separação de atividades e funções ou de grupos sociais no espaço por meio de processos particulares. E é um reflexo da luta de classes, a expressão ambiental da desigualdade social, fragmentada também na segregação étnica.

A desigualdade que se expressa na segregação é um elemento constitutivo da estrutura do espaço de uma metrópole e compõe o movimento que faz surgir ou não a estagnação em determinadas partes e num determinado momento. O modelo de centro e periferia implantado na metrópole e a grande dispersão da periferia são características que 
intensificam a segregação e ameaçam as relações sociais, pois nesse modelo a periferia acaba opondo-se a uma centralidade que revela suas formas enquanto centralidade de decisões (de riqueza, de informações, de poder e de violência) (LEFÈBVRE, 1999).

A produção do espaço leva somente em conta o tempo para sujeitá-lo às exigências e pressões da produtividade. Círculo estranho no qual o tempo está encerrado (LEFÈBVRE, 1999: 179).

A separação originada pela segregação determina o acesso desigual aos equipamentos urbanos e, por outro lado e ao mesmo tempo, a desigualdade de acesso produz a separação. E, mesmo que um dos dois fatores seja eliminado, o outro não desaparece. São processos distintos, mas combinados. A segregação social e a espacial trazem efeitos que desestruturam as oportunidades sociais (MARQUES e TORRES, 2005). Se por um lado inibe as oportunidades de mobilidade, consolidando a pobreza e a vulnerabilidade, de outro lado agrega riqueza e oportunidades de mobilidade e segurança.

A cidade capitalista traz na sua estrutura essa segregação, como muito bem relata a professora Ermínia Maricato:

As cidades refletem o processo industrial baseado na intensa exploração da força de trabalho e na exclusão social, mas o ambiente construído faz mais do que refletir. Como parte integrante das características que assume o processo de acumulação capitalista no Brasil, o urbano se institui como pólo moderno ao mesmo tempo em que é objeto e sujeito da reprodução ou criação de novas formas arcaicas no seu interior, como contrapartida de uma mesma dinâmica (MARICATO, 1996: 43).

A cidade capitalista é um produto do urbanismo segregador, que reproduz as características do processo industrial e favorece a infraestrutura 
de consumo e distribuição industrial num mercado concentrado e restrito. A discriminação social produzida pela concentração de pobreza e a segregação ambiental produzida por um ambiente precário, sem infra-estrutura e disseminador da violência, produzem a segregação urbana.

A estrutura urbana insere os elementos constitutivos da cidade. Com o objetivo de construir um conceito sobre estagnação de um bairro (o Pari) em uma metrópole (São Paulo), é preciso definir o que entendemos por estrutura de uma metrópole. Neste trabalho, a definição de estrutura tem por base o conceito elaborado por Flávio Villaça, que por sua vez se apoia em Roger Bastide:

um todo constituído de elementos que se relacionam entre si a tal forma que a alteração de um elemento ou de uma relação altera todos os demais elementos e todas as demais relações. Observa que as estruturas são dotadas de movimento e que o grande desafio intelectual consiste em desvendar a fonte desse movimento (VILLAÇA, 1998: 12).

Segundo Villaça, os elementos da estrutura territorial são os seguintes:

- Centro principal

- Subcentros de comércio e serviços

- Bairros residenciais segundo classes sociais e áreas industriais (I dem, 12)

Essa estrutura está imbricada a outras estruturas territoriais, como os sistemas de transporte e de saneamento. É sempre dinâmica e tem um movimento intenso, principalmente nas grandes metrópoles. Pode ser ameaçada, minada em seu interior, pela negação e pela totalidade que envolve o todo em movimento, nunca fechado, nunca terminado (LEFÈBVRE, 2000).

A formação da metrópole se dá com o estabelecimento da estrutura de mercado. Sua gênese está no século XVI, quando a acumulação comercial 
começou a quebrar o desenho da cidade e desencadear um processo de metropolização. A cidade no século XVI era o centro da dominação religiosa e, com o surgimento da atividade comercial, passou a comportar os elementos comerciais. A troca é o real ato prático: trocam-se todas as formas de relação, revelando, assim, a cidade comercial. Com a industrialização, a urbanização se expande e a cidade torna-se metrópole. É na metrópole que a viabilização dos negócios se dá de forma mais fluida, rápida e complexa, opaca e ardilosa.

Esse movimento acontece em partes e no todo da cidade, de maneira que a estrutura sempre está em movimento. Cada parte da cidade tem sua especificidade, apesar de elas serem parecidas. É a apropriação dos lugares ${ }^{1}$ que os diferencia por funções, as quais se conflitam e, nesse movimento, as contradições criam a vida possível, a prática do espaço. Os espaços se fragmentam, se homogeneízam e se diferenciam; as formas territoriais se revestem de várias funções na competitividade da metrópole e se particularizam em seu contexto cultural e social (LEFÈBVRE, 2000).

Tomando-se cada parte da cidade como um bairro, percebe-se que ela possui uma dinâmica fechada em si mesma. Da parte ao todo, do bairro à estrutura.

É a estrutura do espaço urbano que assegura condições precípuas para que se possam realizar as atividades de circulação, distribuição, gestão e troca de mercadorias. Na estruturação da metrópole, se dá a divisão social e técnica do espaço, reflexo da divisão social e técnica do trabalho. Essa divisão é manipulada pelo mercado com o apoio do Estado, que é a representação da classe dominante, que por sua vez age por meio do mercado. O conflito de interesses e a concorrência dos agentes usuários do espaço urbano é refletido pelo poder econômico e político. A localização das atividades é fruto de um jogo das necessidades locacionais com as suas possibilidades em termos econômicos e políticos, tanto para as atividades no espaço como para as classes sociais. As práticas de apropriação realizadas

\footnotetext{
${ }^{1}$ Entende-se o lugar como o espaço da prática. O conceito de lugar, no presente trabalho, é o espaço que é apropriado, vivido. Lugar como parte do espaço geográfico onde vivemos e interagimos. Não é apenas um ponto de uma coordenada geográfica.
} 
dentro da estruturação do espaço urbano mostram a contradição fundamental desse processo.

Na estruturação do espaço metropolitano, a estagnação de um bairro se contrapõe à transformação de outro. Ou seja, enquanto o Estado e o mercado procuram investir em determinada área, deixam outras de lado. A escolha de investimento em determinado espaço é uma opção política que faz parte do modelo idealizado de cidade capitalista. A herança autoritária conduz a escolha de forma a excluir a participação da população, sobretudo porque a mídia assume o papel de guardiã dos interesses da classe dominante, não havendo, assim, possibilidade efetiva de diminuir as desigualdades sociais e também espaciais.

O comportamento do homem da metrópole, que se manifesta nas relações abstratas e fragmentadas, é produzido pelo predomínio do capital. O homem moderno reproduz o sistema capitalista, em que se verifica a supremacia da mercadoria e do imediato. Indiferente ao outro, valoriza apenas o mundo objetivo. A sociabilidade da metrópole ocorre de forma fragmentada, baseada na divisão social do trabalho (ARANTES, 2000).

Esse processo de formação da metrópole capitalista, que desumaniza as relações sociais, por ter sua base predominantemente nas relações de troca e exploração do trabalho, está bem representado na metrópole São Paulo. Sua estrutura territorial (que pode ser identificada no Mapa 45) se 
MAPA 45 - Município de São Paulo com os principais elementos da estrutura urbana

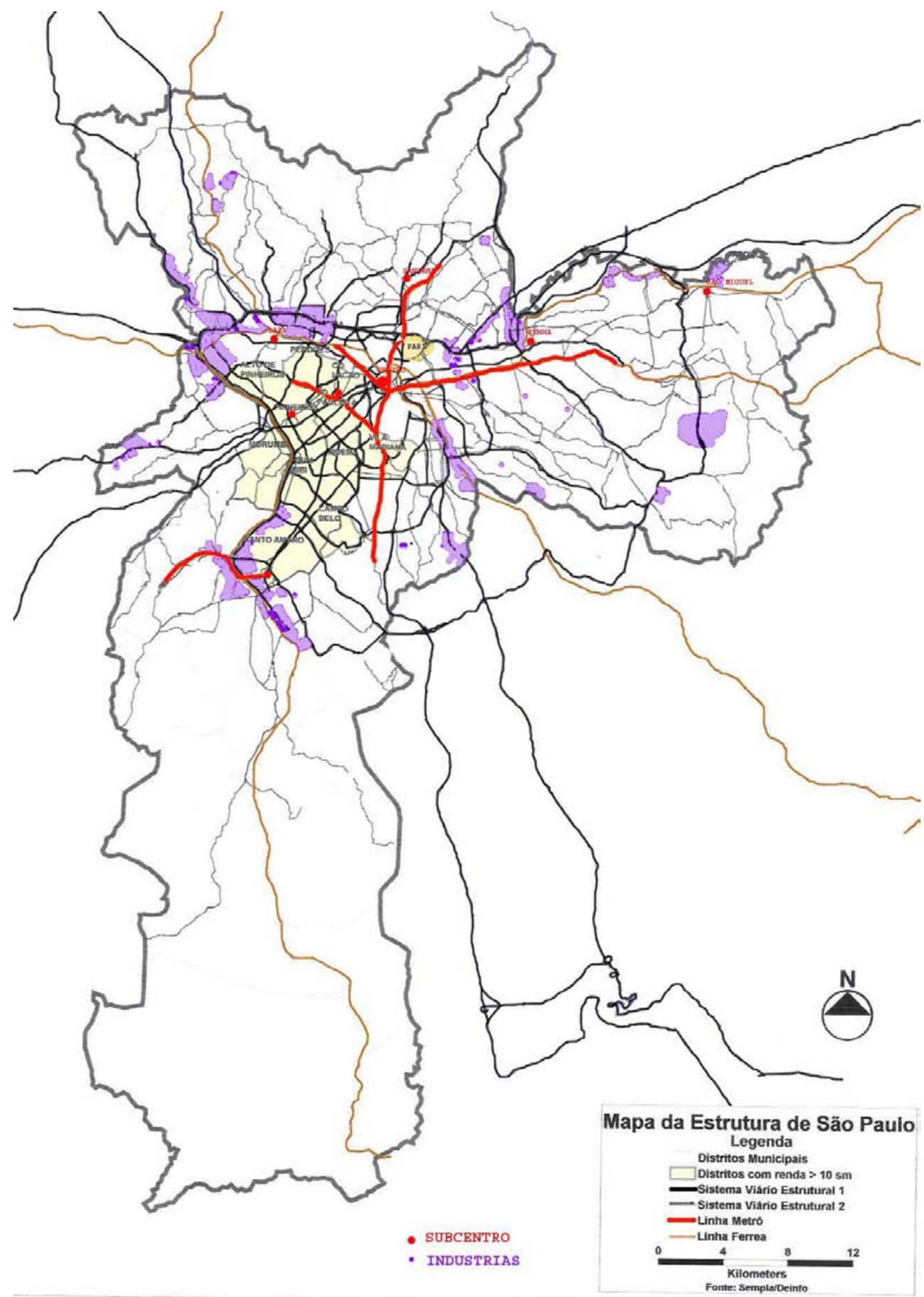

Fonte: elaboração da autora, a partir dos elementos de Villaça (1998) 
articula a outras não territoriais, como a econômica e a política, e todas dominadas pela ideologia.

Historicamente, a metrópole paulistana foi estruturada a partir das linhas férreas implantadas no final do século XIX. Antes, havia núcleos esparsos, antigo cinturão de chácaras que foi anexado à cidade por uma expansão urbana difusa. Esse antigo cinturão caipira se valorizou, graças à sua posição geográfica vantajosa e às atividades econômicas que foram sendo aí estabelecidas, ocorrendo a reorganização dos arredores paulistanos.

O fato é que a configuração espacial da cidade foi produto de uma lógica de interesses entre proprietários imobiliários, empresas implementadoras de infraestrutura urbana e administração pública. A abertura de arruamentos, na maior parte dos casos, foi fruto de iniciativas casuais, isoladas e desarticuladas entre si, muitas vezes encetadas por chacareiros, que se aproveitavam da valorização de suas propriedades, em virtude do crescimento da cidade, para retalhá-las (BRITO, 2000).

Os primeiros núcleos urbanos foram orientados pelas redes ferroviária e viária. Depois de 1892, iniciou-se a primeira reestruturação da cidade, com a inauguração do Viaduto do Chá, que ultrapassou o Vale do Anhangabaú para constituir "a cidade nova". Em 1930, um grupo de particulares ${ }^{2}$ propôs a realização de um conjunto de avenidas, que ligava a Avenida I piranga e a Avenida Rio Branco, unindo os bairros de Vila Buarque, Santa Ifigênia e Campos Elíseos (OSELLO, 1980). Em 1930 o Plano de Prestes Maia foi lançado e, a partir de 1945, o projeto de novas vias começou a ser implantado, dando uma nova configuração à cidade e formando uma estrutura, suporte até os dias hoje de um sistema de acesso rápido (na época) por automóvel da área central para a periferia.

A metrópole de São Paulo concretizou-se com uma estrutura radioconcêntrica e constitui um organismo político administrativo altamente centralizado. O arranjo espacial, apoiado na infraestrutura viária, na rede de transporte, além de oferecer eixos à expansão metropolitana, provocou a estruturação de polos cristalizadores do desenvolvimento em escala local. À

\footnotetext{
${ }^{2}$ Conde Prates, Plínio da silva Prado, José Paulino Nogueira, José Martiniano Rodrigues Alves, Francisco de Paula Ramos de Azevedo, Arnaldo Vieira de Carvalho.
} 
medida que crescia, a cidade foi plantando tecidos fragmentados, superpondo uns aos outros, numa colagem incessante de usos e ocupações intermináveis. A metrópole, assim, abandonou todo o sentido de continuidade e desenvolveu a capacidade de pilhar a história e absorver dela tudo o que classifica como aspecto do presente.

Os bairros foram se desenvolvendo acompanhando a forma radioconcêntrica das avenidas previstas no Plano Prestes Maia (principalmente), seguindo para todas as direções da cidade, mas de maneira distinta. Para a região sudoeste, ela foi estruturada e reestruturada por grandes avenidas de fundo de vale, que deram uma configuração organizada a essa parte da cidade. Enquanto que, para o sentido leste, só houve investimento para a penetração, sem preocupação de articulação com outras vias. Dessa forma, o espaço foi estruturado acompanhando a planície do Rio Tietê, da estrada de ferro e da Radial Leste, a principal via na direção leste. As avenidas de fundo de vale da região leste vieram bem mais tarde, depois que a cidade estava consolidada.

A metrópole se dinamizou como resultado da implantação de vias e do transporte de massa. A cada obra em uma determinada região ou direção da cidade, surgiam ou cresciam bairros. Contudo, esse processo não se deu na metrópole como um todo de forma indistinta. A porção sudoeste, local dos moradores de maior renda, foi sempre a mais privilegiada. Ao analisar a estrutura da cidade, percebemos que ela não é uniforme, que pende para o quadrante sudoeste. Os bairros também evoluíram de forma desigual. Uns alcançaram grande desenvolvimento, com um dinamismo imobiliário muito forte; em outros o processo foi mais lento; outros, ainda, pouco progrediram; e alguns tiveram um crescimento grande e depois retrocederam. Dentre estes últimos, os que tiveram um ápice de desenvolvimento e depois romperam com esse processo foram, particularmente, os bairros centrais. Por que e como acontece isso na cidade?

Como já se viu acima, a uma divisão social estrutural e hierárquica do trabalho corresponde uma divisão estrutural e hierárquica do 
espaço, relação essa que é evidente no contexto da metrópole. Sua estrutura influi diretamente na localização dos núcleos centrais de cada área, na distribuição das funções e na inter-relação entre as diversas regiões. Os bairros mais bem localizados possuem uma vitalidade que se manifesta em atividades diversas. Os que apresentam usos de menor status têm uma relação menos intensa com a cidade. Essa divisão se manifesta também na forma como os moradores dos dois tipos de bairro se apropriam do espaço público como uso. Nos bairros operários esse uso é frequente, e não se reproduz nos bairros de alta classe. O burguês tem fobia pelo lugar público, onde ele é um anônimo, só encontrando o reconhecimento e o prestígio de que se julga merecedor no refúgio doméstico (ARANTES, 2000).

Para as relações sociais existirem no bairro é preciso que o espaço seja apropriado por sua população, pois a cidade e seus bairros já existiam antes da cidade capitalista, quando a urbanização da metrópole os abarcou, estabelecendo-se uma forma de espacialização do processo social. A questão é que o bairro passou a existir à medida que a prática social acontecia, foi ganhando objetividade, tornou-se empiricamente observável, manifestando os níveis de institucionalidade, por sua vez, das continuidades históricas, que, no entanto, articulavam por dentro a vida do bairro. Cada bairro, embora não seja território demarcável, tem um perfil que deriva dos conteúdos que lhe são específicos (SEABRA, 2003).

A estagnação de partes, de fragmentos ou bairros de uma metrópole é um fato. É frequente encontrar em textos acadêmicos sobre o urbano o termo "estagnação urbana" para designar um fenômeno com complexos fatores.

A reestruturação produtiva em São Paulo causou seu reflexo no espaço. Por reestruturação produtiva da metrópole entende-se o processo pelo qual o capital, com seus ritmos e intensidades diversos, modifica sua estratégia de circulação, ampliação e acumulação (Harvey, 1993). Essa reestruturação teve início na década de 1970 e foi descrita pelo autor supracitado como o movimento pelo qual o capital interveio no espaço urbano, ao buscar novas formas de obtenção de lucro, intervenção esta 
caracterizada por um maciço investimento territorial e uma forte expansão urbana, que inauguraram uma nova fase na economia.

A estagnação é a outra face da moeda da "reestruturação econômica do espaço", que também provoca muitas inovações. Enquanto algumas partes da cidade são chamadas de "espaço globalizado", em decorrência do forte investimento público e privado, com a concentração de várias atividades econômicas nacionais e transnacionais de alto padrão e de funções múltiplas, outras, em comparação, ficam numa situação de inércia e ociosidade. A área da metrópole chamada de "cidade global" é apresentada por Whitaker Ferreira como um mito construído pela academia, pelos profissionais do urbanismo, com ajuda especial da grande mídia (FERREIRA, 2008). Na teoria de "cidade global" o autor supracitado sistematizou o que se define por cidades globais por meio de onze itens (pp. 23 e 24) que podem ser resumidos nos seguintes atributos:

- relação de um espaço específico com a economia global, com grandes volumes de negócios transnacionais;

- fluxo intenso de executivos de negócios;

- sedes de grandes empresas transnacionais e de empresas "de ponta";

- grandes atividades do setor financeiro;

- atividades voltadas ao turismo de negócios.

Esses atributos são do domínio de um “lócus privilegiado para a acumulação e concentração do capital transnacional, na fase atual do capitalismo financeiro globalizado" (FERRREIRA, 2007: 20).

A palavra "globalização" é um neologismo, que só aparece na literatura na década de 1980. Mas, como demonstra François Chesnais, a globalização é uma etapa específica, muito avançada, do velho processo de internacionalização do capital - um dos movimentos estruturais e estruturantes do capitalismo. Na intensidade e na extensão com as quais tal processo se manifesta hoje, ele é novo - e a palavra globalização pretende expressar tal novidade. Mas o movimento começa no século XVI, quando o 
capitalismo se firma, e vem acompanhando esse modo de produção ao longo de suas várias fases.

A história do Brasil está atrelada ao movimento de internacionalização em seu próprio nascedouro. O "descobrimento" do território americano pelos europeus decorreu do processo de internacionalização comercial. E o país se ligou a esse processo como colônia de exploração. Tal contingência produziu uma pesada herança que carregamos até hoje. Quando o pacto colonial se tornou um obstáculo ao processo de Internacionallzação, ele foi derrubado, e no Brasil isso se expressa na chamada abertura dos portos, em 1808. No século XX, o país reafirmou sua inserção, subordinando-se à internacionalização do capital produtivo.

O uso da expressão "cidade global" reflete uma ideologia criada com o objetivo de esconder o real. O termo, muito difundido nos países subdesenvolvidos, dá visibilidade e representatividade à "cidade" da classe dominante e tenta esconder a pobreza, considerando seus sujeitos como residuais e descartáveis. A ideologia é dominada pela lógica da mercadoria e do dinheiro, pela quantidade; e é perversamente recoberta pelo fascínio do maravilhoso e ilimitado das coisas que podem ser compradas e vendidas. A globalização já havia sido preconizada por Marx. Ele percebeu que uma economia internacional globalizada era inerente ao modo de produção capitalista. E de fato ela é hoje uma realidade irreversível.

A transitoriedade das coisas dificulta a preservação de todo sentido de continuidade histórica. (Se há sentido na história, há que descobri-lo pelo movimento) (HARVEY,1993: 22).

O distrito do Pari, assim como outras partes da cidade, é completamente ignorado pelas teorias urbanísticas ou pela análise objetiva de planos ou gestões específicas. Pela teoria de "cidade Global", ao analisar o Pari, vê-se que nessa área não existe cidade global. O bairro faz parte do outro lado da moeda. É a simbiose do sistema implantado historicamente. Faz parte do desenvolvimento desigual e combinado, como diz Chico de Oliveira: 
No plano teórico, o conceito do subdesenvolvimento como uma formação histórico-econômica singular, constituída polarmente em torno da oposição formal de um setor "atrasado" e um setor "moderno", não se sustenta como singularidade: esse tipo de dualidade é encontrável não apenas em quase todos os sistemas, como em quase todos os períodos. Por outro lado, a oposição na maioria dos casos é tão-somente formal: de fato, o processo real mostra uma simbiose e uma organicidade, uma unidade de contrários, em que o chamado "moderno" cresce e se alimenta da existência do "atrasado", se se quer manter a terminologia (OLIVEIRA. 1976: 32).

O autor continua, dizendo que a ideologia da classe dominante é hoje tão escancarada, que essa classe já se afirmou de tal modo que a face já não precisa de máscara. E ainda acrescenta que o papel do Estado é "institucionalizar" as regras do jogo. E segue:

As formas de consumo imposto de fora para dentro parecem não ter nada que ver com a estrutura de classes, com a forma da distribuição da renda, e são impostas em abstrato: começa-se a produzir bens sofisticados de consumo, e essa produção é que cria as novas classes, é que conforma o padrão de distribuição da renda, é que "perverte" a orientação do processo produtivo, levando no seu paroxismo à recriação do "atraso" e do "moderno" (I bidem: 49).

Pode-se, também, citar Roberto Schwartz quando analisa a sociedade brasileira que suporta essa situação do moderno e do arcaico:

O fundamento efetivo estava no que a tradição marxista identifica como o "desenvolvimento desigual e combinado do capitalismo", expressão que designa a equanimidade sociológica particular a esse modo de produção, o qual realiza a sua finalidade econômica, o lucro, seja através da ruína de formas anteriores de opressão, seja através da reprodução e do agravamento delas. Contrariamente ao que as aparências de 
atraso fazem supor, a causa última da absurda formação social brasileira está nos avanços do capital e na ordem planetária criada por eles, de cuja atualidade as condutas disparatadas de nossa classe dominante são parte tão legítima e expressiva quanto o decoro vitoriano (SCHWARZ, 2000: 39).

Outro autor que corrobora a análise da sociedade brasileira sob esse prisma é José de Souza Martins. Ele mostra como se realiza o ritmo das relações de produção combinadas com formas arcaicas no estabelecimento do capitalismo. Essa é uma referência fundamental em sua obra:

\begin{abstract}
Marx assinalou, em mais de uma ocasião, a questão do ritmo das transformações históricas com o advento do capitalismo, indicando que as relações capitalistas de produção, uma vez instauradas, se disseminam pouco a pouco, de forma até imperceptível como se nenhuma transformação estivesse ocorrendo (MARTINS, 1998:22).
\end{abstract}

O desenvolvimento urbano desigual, em vez de eliminar a herança do atraso, reproduziu-a e deu-Ihe novas conformações. Segundo Martins,

(...) o capitalismo na sua expansão, não só redefine antigas relações, subordinando-as à reprodução do capital, mas também engendra relações não capitalistas igual e contraditoriamente necessárias a essa re-produção (IDEM: 19).

É com essa visão da sociedade fragmentada - onde ocorrem ao mesmo tempo o desenvolvimento do capitalismo contemporâneo (a globalização) e arcaico (os espaços estagnados) - que se interpreta estagnação no presente trabalho. Esse movimento é constatado na metrópole paulistana, em vários casos de bairros que mudaram seu rumo, que tiveram seu processo freado em consequência de causas específicas a cada um. 
A noção de desenvolvimento desigual introduz alguns elementos novos no conceito do momento crítico. A crise não acontece ao mesmo tempo e do mesmo modo nos diferentes setores da prática social, em diferentes sociedades.

No Pari, essa divisão é claramente explícita, resultando em atividades bastante diversificadas. Há indústrias, comércio varejista de diversos produtos, comércio especializado e comércio local. E por outro lado há muitos moradores de baixa e média renda, além de muitos cortiços e até poucas favelas. E muitos usos institucionais.

Cada uso possui uma intensidade própria, criando uma singularidade específica no bairro. Entre a concorrência e a competição dos preços de seus produtos no mercado, as atividades de cada espaço gradualmente se ampliam, estagnam ou nem sequer chegam a crescer. Cada parte do espaço tem sua especificidade e depende de sua articulação com a cidade para se concretizar no urbano. Como afirmam o prof. Lamparelli e outros:

O espaço do capital exprime essa tendência dupla do modo de produção capitalista que é a de aglomerar capital fixo num ponto e de se expandir através da multiplicação desses pontos, abarcando áreas cada vez maiores e causando assim o chamado "desenvolvimento desigual e combinado" (CAMARGO, LAMPARELLI, GEORGE, 1980:23).

Além de suas atividades diversificadas, o Pari possui uma acessibilidade ímpar quanto aos recursos de transporte de massa e proximidade com o sistema viário estrutural da metrópole, o que facilita sua ligação com qualquer parte da cidade. É atendido por transporte público e possui todos os equipamentos sociais necessários à fruição da vida cotidiana.

A constatação da estagnação do bairro, é abordada no comportamento atual das atividades não residenciais e a inter-relação com seus moradores e frequentadores em relação a um tempo passado. Encontramos o ponto do auge da vitalidade das atividades - e quando esse ponto inflectiu e começou a declinar para atingir a situação de estagnação - 
e identificamos os fatos que nos induziram a pensar que o bairro está estagnado ou se essa conotação é uma mera invenção ideológica.

É muito importante para a análise da relação bairro-metrópole entender o cotidiano do lugar. Isso implica deslocar o econômico para o social, entreter-se no momento do movimento da evolução histórica da sociedade, que hoje passa, quase apenas, pela lógica da mercadoria. Por exemplo, a separação dos espaços temporais casa/trabalho é nítida na sociedade atual - e é no bairro, pela repetição, alienação e lugar da consciência, que a contradição é constante; é ele, portanto, o lugar para superar cisões - o lugar das transformações.

Pertencer à Subprefeitura da Mooca, a partir de 2004, em razão da lei no 13.399/02, que criou as subprefeituras e modificou a disposição dos distritos foi um ato singular para jogar o Pari para a zona leste. Por pressão do "Viva o Centro", os distritos do Pari e do Brás foram deslocados a leste, integrando a subprefeitura da Mooca. Desde quando existe delimitação administrativa no município, esses dois distritos pertenceram ao Centro, à Administração Municipal da Sé. A decisão de integrá-los à Subprefeitura da Mooca acentua seu caráter descartável, sua fragilidade ou a falta de interesse das autoridades, do poder e da elite empresarial em reconhecer esses fragmentos da cidade, - toda a Zona Leste - como descartável do ponto de vista da "boa aparência" da cidade. É uma área da metrópole em que o investimento dos empresários mobiliários só se verifica se houver possibilidade de obtenção segura de lucros.

A questão da estagnação urbana está diretamente ligada aos interesses do mercado imobiliário e da ação do Poder Público em considerar esse ou aquele espaço estratégico para ser transformado internamente e em propor-lhe nova qualificação. Essa atitude nasce dos interesses reais da classe dominante.

É exemplar a notícia que surgiu na semana de 15/08/2008, na qual o Ministério da Cultura, por meio do IPHAN, eleva o bairro do Bom Retiro à categoria de excepcional interesse cultural, pela diversidade de etnias dos que ali habitam ou já habitaram ou, ainda, que trabalham ou têm qualquer 
atividade no local. Na verdade, a diversidade cultural que lá se encontra é a mesma disseminada por toda a cidade formada antes de 1960. Não é uma tradição específica desse bairro dentro da metrópole. Praticamente todos os bairros antigos, operários, do centro de São Paulo, possuem esse atributo. Mesmo que de origens diversas, na maioria dos bairros antigos, os estrangeiros estão todos misturados entre si, porque a cidade é intrinsecamente formada por imigrantes. Ora, agora o IPHAN quer institucionalizar apenas um bairro, como eminente representante da diversidade cultural de São Paulo! Está claro que há outros interesses por trás da proposta, e esses interesses representam quem? Essa atitude é uma invenção de tradição, sobre a qual Hobsbawn muito bem discorreu em seu livro $A$ invenção das tradições.

Por tradição inventada entende-se um conjunto de
práticas normalmente reguladas por regras tácitas ou
abertamente aceitas; tais práticas, de natureza ritual ou
simbólica, visam inculcar certos valores e normas de
comportamento através da repetição, o que implica,
automaticamente, uma continuidade em relação ao passado
(HOBSBAWN, 2002:9).

Assim como inventar uma característica excepcional de um bairro, pode-se também inventar uma data de sua fundação, ou outro dado, com o intuito de, sempre que possível, tentar estabelecer uma continuidade com um passado histórico que seja apropriado. A diversidade histórico-cultural, que é própria da geografia e da história, sempre esteve presente nos bairros antigos da metrópole, e guarda como singularidade um sistema de relações que se verifica por toda a cidade.

A aparente inclusão cultural e social faz parte de uma política de reforço das identidades locais, mas que numa sociedade de massa e numa economia globalizada resulta na fragmentação e na exclusão propriamente dita. As estratégias identitárias integram, sem conflito, uma globalização 
econômica que em grande parte se alimenta das diferenças. Otilia Arantes coloca em foco o conflito:

[...]a pretensa "apropriação simbólica" via encenação das diferenças, patrocinadas pelas políticas patrimoniais e culturais dos governos e outras entidades locais, tanto quanto o propósito de acertar contas com o esteticismo e a "frivolidade" das pósfilosofias contemporâneas, cujo "texto" pretende-se com involuntária razão "apenas" reproduzir esse mesmo processo indefinido de desdiferenciação cultural (ARANTES,2001: 154).

A civilização é a reunião específica dos traços culturais que a constituem, o espaço que eles ocupam, a longa duração de sua vida e as sociedades às quais eles dão sua aparência. Portanto, acreditamos que a duração pertence às coisas, mas sua construção - os cortes, as correlações, a continuação e a descontinuação - é produzida pela consciência historiadora. Percebe-se o tempo como dialética da duração (BRAUDEL, 1992).

Hoje se vive sob o total domínio do capital. A magnitude desse domínio é de tal proporção que parece tornar impossível uma resposta - e os homens tornam-se então animais apolíticos. Falta a resposta política. O que importa é o novo, a novidade:

Tudo se passa como se a sucessão temporal por assim dizer se imobilizasse, congelada, numa espécie de espacialização do tempo, como se o passado se projetasse na memória reduzida a um simples monitor onde tudo aparecesse simultânea e fragmentariamente (ARANTES, 2001:42).

A metrópole concentra dois movimentos diferentes, mas complementares na exploração e alienação dos trabalhadores: de um lado, dilapidação da força de trabalho pelas condições impostas pelo capital; de outro, um mercado de ilusões onde cada dia mais intensamente o mundo da 
publicidade e da promessa de felicidade se infiltra na sociedade, produzindo uma atmosfera de consumismo e de "pseudo-abundância" - uma máquina de produzir conformismo (BRANT e KOWARICK, 1975).

As invenções têm sempre por objetivo criar formas de dominação sobre a população. Assim, entender essa relação, entrar na contradição do bairro, compreender esse movimento foi nosso propósito ao tentar decifrar a existência de estagnação ou não.

O espaço é produzido historicamente dentro do contexto do conflito de interesses do morador, do usador ${ }^{3}$ e do explorador. É na história da cidade que se afirma a história dos bairros. Marx afirma que a consciência humana é sempre social e histórica, isto é, determinada pelas condições concretas de nossa existência (MARX, 1974:127). Nossas ideias são formadas por nossa experiência social.

A realidade é um processo em movimento produzido pelos homens que se relacionam entre si e com a natureza. Essas relações produzem ideias que, no entanto, tenderão a esconder o modo real como as relações são produzidas e a origem das formas sociais de exploração econômica e de dominação política, como observou Chauí (CHAUí, 1983:21).

A ideologia aparece como ideias independentes da realidade histórica e social, dissimula a realidade através dessas ideias, dando-Ihe uma forma compatível com as ideias elaboradas. A história é prática, é o real, é o movimento incessante pelo qual os homens, em condições que nem sempre foram escolhidas por eles, instauram um modo de sociabilidade e procuram fixá-lo em instituições determinadas.

A ideologia fabrica histórias imaginárias que nada mais são do que uma forma de legitimar o poder da classe dominante. A luta contra o poder, dizia Hannah Arendt (1989), é sempre a luta da memória contra o esquecimento. Interessa aos que detêm o poder produzir a amnésia, de forma que eles sempre possam reescrever a história nos termos que mais Ihes sejam convenientes.

\footnotetext{
${ }^{3}$ Palavra já definida na nota 3 do capítulo 2.a.l.
} 
As ações temporais e espaciais nunca são neutras nos propósitos sociais, elas exprimem um conteúdo de classe fruto de uma intensa luta social. Isso é claramente explicitado quando se percebem os modos pelos quais o espaço e o tempo se vinculam com o dinheiro e por consequência com o desenvolvimento do capitalismo. A organização das práticas sociais refletida no espaço e no tempo é fundamental para a acumulação e a ampliação do capital que, confrontadas às condições de luta social, tornam as relações instáveis.

A história das realizações do homem comum no espaço da cidade é um fator primordial da formação da concepção do espaço coletivo. É interessante observar que a percepção do espaço está ligada à necessidade e à apropriação do espaço, ambas reflexos culturais. É sempre importante notar o processo dos fatos, do cotidiano e seu movimento. Da reprodução automática, mimética da vida.

Falar sobre os bairros operários e a história do homem que ali vive ou viveu não é prática corrente. A história quase sempre se preocupa com os grandes acontecimentos, os monumentos e os fatos que marcaram a história oficial, a história da classe dominante. Assim, o espaço pode exprimir diferenças inerentes a cada cultura de um bairro, mas a desigualdade social é a expressão dessa luta, das riquezas mal distribuídas.

A metrópole, com seu dinamismo econômico em constante movimento, propicia a ilusão de que os conflitos se resolverão espontaneamente. Contudo, a desigualdade social e espacial são os reais dilemas da sociedade urbana. O espaço, como produto social, reproduz as desigualdades inseridas nele próprio. E estas revelam que a hegemonia espacial dominante é obra da própria estrutura econômica.

A metrópole e sua sociedade não possuem mecanismos de autoregulação que se bastem. A ação dos homens na busca para estruturar uma sociedade mais igualitária fica sempre mais debilitada. A dominação do espaço é uma ação teleológica de poder social na e sobre a vida cotidiana. $\mathrm{Na}$ metrópole os indivíduos são fragmentados e articulados por interesses, ocupando qualquer espaço, o espaço possível. Por isso a metrópole tem 
recortes variados. Apesar de a massa ser visível - a multidão - , a relação do lugar na metrópole é precária, é efêmera. A organização espacial deve intervir no poder para promover mudanças radicais, do contrário a produção do espaço será sempre um instrumento político de controle social que o Estado usa para promover seus interesses.

\section{3.b- Os bairros centrais e a estrutura da metrópole}

Na crise internacional do início da década de 1970, assistiu-se a uma profunda reestruturação produtiva, responsável pela expansão da grande empresa operada em rede, especialmente nas corporações transnacionais. A transformação da estrutura do mercado de trabalho repercutiu na ocupação e apropriação do solo urbano. Este é o primeiro aspecto a ser enfatizado ao se analisar a transição da metrópole de 1970 para a contemporânea. A passagem da acumulação capitalista nesse novo estágio, associada a um sistema de regulamentação política e social distinta da era do compromisso fordista, trouxe à metrópole um aspecto de "cidade global ou mundial" 4. A acumulação flexível - flexibilidade dos processos de trabalho - dos mercados de trabalho, dos produtos e padrões de consumo rápidos afetou os padrões do desenvolvimento desigual - que, no entanto, não desapareceu; pelo contrário, as diferenças sociais se aprofundaram, e apenas se tornou possível esconder melhor a pobreza.

O aprofundamento do desenvolvimento desigual da cidade aparece na contraposição entre inúmeros investimentos produtivos, em determinados espaços, e o abandono de outras áreas. Os investimentos mostram-se sempre visíveis, sempre que seja do interesse da classe dominante ou do poder, e são apresentados, de forma capciosa, como benéficos para toda a cidade. Esse modelo da prática na metrópole revela-se como ausência de apropriação por parte da maioria da população (DAMIANI, 2000). A estrutura da metrópole é definida,

\footnotetext{
${ }^{4}$ A compreensão do conceito de "cidade global" já foi interpretada no capítulo 1.
} 
mas temporária, cheia de contradições. O desenvolvimento desigual da cidade, como concepção de subdesenvolvimento, em certo momento, parece apontar para a imobilidade social. Mas o espaço permanece fragmentado entre pobres - a grande parte da metrópole - e os ricos - com alguns pontos especiais e estratégicos. A aparência desordenada do crescimento metropolitano encobre a organização da sociedade. O aparente caos urbano esconde a ordem do sistema (idem).

Prof. Csaba analisa as mudanças sofridas pelo capitalismo contemporâneo no Brasil levando em conta a especificidade da sociedade brasileira, uma sociedade de elite cujas raízes remontam à época colonial (DEÁK, 1991). O autor sustenta que o processo de acumulação entravada que se verifica no país tem uma dialética interna própria, em que o imperativo da acumulação está subordinado ao princípio da expatriação do excedente, como processo precípuo de produção capitalista que forma a base econômica para a reprodução ampliada da sociedade de elite no Brasil (idem). A hegemonia da ideologia neoliberal levou a dependência cultural ao paroxismo, tornando as sociedades periféricas, particularmente vulneráveis, a processo de mercantilização difundido pelo novo padrão de desenvolvimento capitalista.

Essa situação impede que o desenvolvimento econômico e seu reflexo no espaço sejam transformados. O desenvolvimento dependente reflete a forma que as transformações capitalistas assumem em sociedades marcadas por uma grande separação social, nas quais a população é segmentada em duas categorias: “Os possuidores de bens", que monopolizam todos os benefícios do sistema, e os "não-possuidores de bens", a maioria dos quais verdadeiros "condenados ao sistema" (SAMPAIO Jr, 1999).

O processo de urbanização das cidades brasileiras, marcado pela separação social das classes, é produto direto do desenvolvimento econômico.

As sucessivas revoluções tecnológicas, as relações sociais, os hábitos de consumo, os estilos de vida e similares, que caracterizam a história capitalista podem, ser entendidos sem nenhuma indagação mais profunda sobre as raízes e a natureza 
dos processos urbanos (HARVEY, Espaço e Debates $n^{\circ} 39$ : 48).

Por esta razão parece valer a pena pesquisar qual o papel que o processo urbano estaria desempenhando na atual reestruturação radical da distribuição geográfica das atividades humanas e da dinâmica político-econômica do desenvolvimento geográfico desigual, no espaço metropolitano paulista. As aparentes transformações ocorridas em pontos estratégicos da cidade aprofundam a estrutura desigual da cidade. O poder do grande capital - produtivo, financeiro, das elites locais e dos agentes internacionais - se sobrepõe ao poder de gestão da cidade. O desenvolvimento urbano e sua reestruturação ficam à mercê desses interesses que sustentam as políticas públicas urbanas.

A opção por um determinado espaço da cidade advém da própria reestruturação do capital que provoca a centralização do capital e isso implica necessariamente em concentração de intervenções. A possibilidade de os investidores privados escolherem uma determinada parte da cidade está diretamente relacionada aos investimentos anteriores sustentados pelo Poder Público. Investir em uma área não promissora em um futuro próximo é praticamente impossível.

Assim, os investimentos ocorridos ou que vierem a ocorrer na área central devem assegurar um retorno mais ou menos rápido ou receber grandes incentivos legais do poder público, como é o caso da Concessão Urbanística implantada na área da Luz ou até mesmo a Operação Urbana Centro. Caso contrário, não vale a pena a empreitada.

No presente trabalho é adotada como área central a antiga divisão distrital de 1991 da Administração Regional da Sé (AR-Sé), que, com uma extensão de aproximadamente $32,6 \mathrm{~km}^{2}$, era formada por 10 distritos: Sé, República, Consolação, Santa Cecília, Bom Retiro, Pari, Brás, Cambuci, Liberdade, Bela Vista (Mapa 46). Em 2002 foram subtraídos os distritos do Pari e do Brás pela Lei no 13.399, de 2002, que criou as subprefeituras, a partir do que o formato da Subprefeitura da Sé tornou-se banguela, deixando de existir a configuração de um núcleo anular, indicando visualmente o centro da cidade - a Sé. Optamos pelo 
limite da antiga AR-Sé porque, se considerarmos apenas a atual Subprefeitura da Sé, os distritos do Pari e do Brás ficariam de fora da área central, o que compromete a análise do trabalho, tendo em vista que a área central continua sendo o limite antigo da Administração Regional da Sé, tanto para os moradores, como do ponto de vista da dinâmica urbana: a atividade econômica e sua relação com a metrópole. O motivo do desligamento desses dois distritos da Sé para a Zona Leste (subprefeitura da Moóca) ocorreu por pressão da Associação Viva o Centro, que entendia que essa configuração traria menos problemas para a administração do centro da cidade, onde ela possui um trabalho ativo.

\section{Mapa 46 - Área Central - Município de São Paulo}

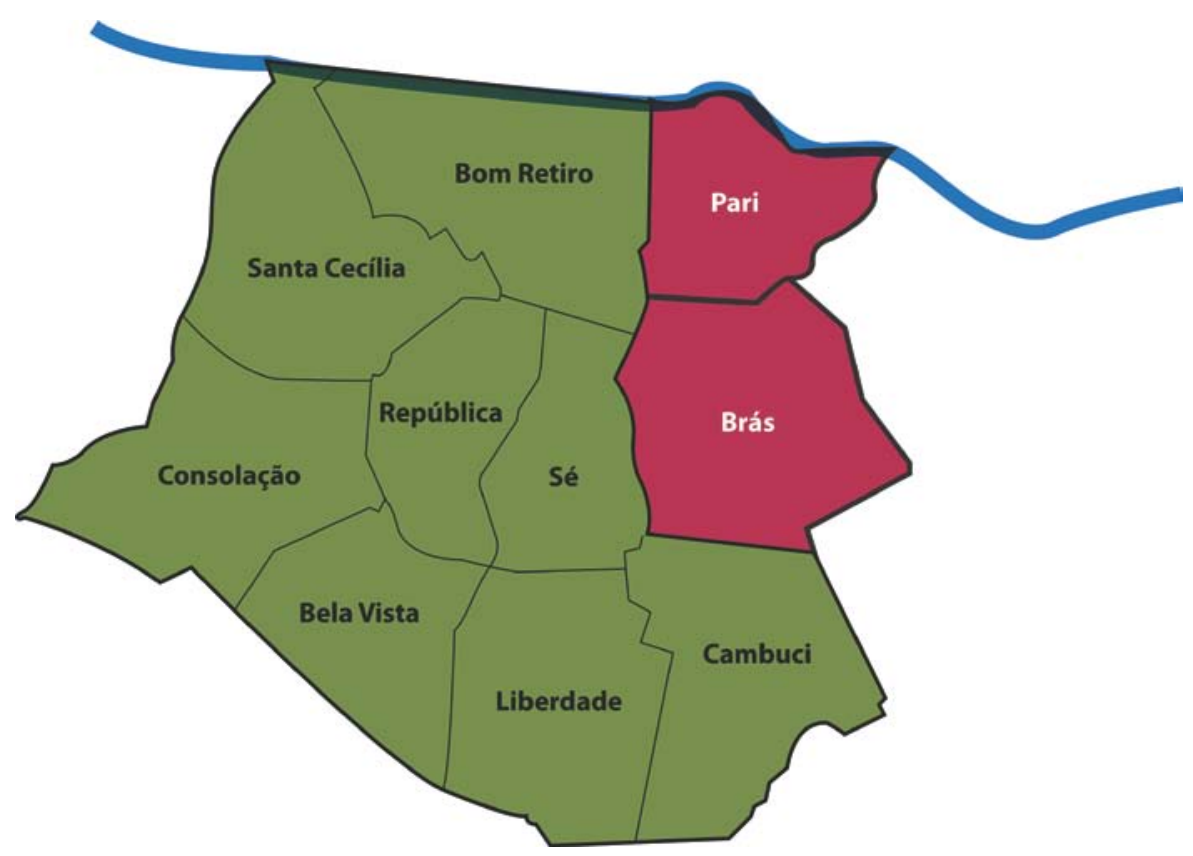

Os moradores dos dois distritos excluídos da área central (Pari e Brás) se sentem alijados do processo e não concordam com tal procedimento. O Pari, objeto de estudo deste trabalho, torna-se assim um bairro da Zona Leste, mas seus moradores, na sua cotidianidade, continuam sendo atraídos pelo Centro, por 
proximidade, e por existir uma relação histórica intrínseca e inseparável entre este e o bairro. Por esse motivo não analisamos o Pari como um bairro da Zona Leste, mas integrando o Centro Histórico do município.

Podemos considerar o Centro Histórico como o espaço abrangido pelos distritos Sé e República, espaço circundado por um anel de bairros de uso misto. São, em alguns casos, antigas áreas de uso misto com predominância industrial; outros apresentam comércio ou serviços especializados, como Brás, Pari, Santa Ifigênia, Barra Funda, Canindé e certos trechos da Mooca, do Cambuci, da Bela Vista e do Belém. É esse anel que forma a área central, assim considerada tanto pela visão popular como pela de urbanistas.

A área central do município possui uma atratividade cultural e social excepcional, que abarca muitos bens protegidos pelo Estado e pelo Município. Possui 5 bibliotecas públicas, 53 salas de cinema, 75 salas de teatro, 19 salas de shows e concertos e 17 museus $^{5}$, além de concentrar grande parte do serviço bancário e financeiro da metrópole e do país, junto com o comércio popular e informal. Esses números contrastam com o pequeno número de moradores da região que utilizam esses serviços e com o grande número de moradores de rua.

É na região central que existe o maior entroncamento de transportes de massa e transporte público de uma estrutura radial que faz convergir para lá os meios de transporte de qualquer parte da metrópole. Abriga também todo tipo de equipamentos sociais.

Apesar da existência de toda essa infraestrutura e condições de atendimento ao consumo em geral, a área foi abandonada pela elite econômica do país, que preferiu criar novos polos, deixando o Centro Histórico para as classes sociais menos favorecidas.

Ao longo das últimas décadas, o parque imobiliário da Área Central foi objeto de um abandono generalizado no tocante aos cuidados de manutenção. De maneira geral, pode-se afirmar que os espaços de escritório, principalmente nos pavimentos não térreos, sofreram mais pesadamente o deslocamento de escritórios e bancos mais dinâmicos para outras regiões da cidade. Isso é

\footnotetext{
${ }^{5}$ Silva, Luis Octavio - Viva o Centro - 2004.
} 
indiciado tanto pela queda dos valores de compra e de aluguel, em relação a outras regiões, quanto pelas altas taxas de vacância, a despeito dos valores demandados (SILVA: 2004:12).

Os investimentos públicos no centro da metrópole têm sido lentos em razão da falta de interesse do mercado imobiliário privado. Mesmo que o planejamento urbano, com seus planos e leis, tente impor uma nova situação, o interesse dos empresários é tão pequeno que todas as propostas ficam sempre na intenção, não sendo reproduzidas no espaço. É uma contradição interna ao planejamento urbano da metrópole.

Muitos consideram como fator determinante para a elite ter abandonado o Centro a antiga legislação de uso e ocupação do solo (lei 8001/72), pois ela possibilitou que empreendimentos não residenciais se espalhassem pela cidade, 0 que levou as empresas a irem embora do Centro. Além disso, a legislação de preservação selecionou inúmeros bens para tombamento, sem no entanto proporcionar mecanismos eficazes para sua valorização e utilização.

Houve muitas intervenções na área central para reverter esse processo de abandono, mas o investimento público não foi eficaz. Deu-se a reurbanização do Vale do Anhangabaú, cujas obras foram concluídas em 1991, e a implantação do Bulevar São João. Por meio de legislação municipal foi aprovada a Operação Urbana Anhangabaú (lei $n^{\circ}$ 11.090/91) e a Operação Urbana Centro (lei $n^{\circ}$ 12.349/97), que resultaram em poucas intervenções concretas. O último investimento do governo municipal foi criar o mecanismo de Concessão Urbanística da Nova Luz, que entrega mais de 40 quadras ao poder privado para que tire benefício de desapropriações e intervenções gerais. Assim, instituindo a especulação imobiliária, o poder público municipal acredita na possível “higienização" do Centro.

No final da década de 1990, o Governo do Estado reformou e converteu a Estação Júlio Prestes em uma sala de concerto para alocar a Orquestra Sinfônica do Estado; e, em 2002, adaptou o antigo edifício do DOPS para lá funcionar o Museu do Imaginário do Povo Brasileiro. Essas duas obras estão próximas da região de maior consumo de drogas da cidade, de um núcleo de economia 
informal e de um outro, especializado no comércio de eletrônicos que atende a todo o país.

O Centro Histórico, apesar de abandonado pela elite econômica e mesmo sofrendo grandes alterações nas últimas décadas, continua bastante dinâmico e popularizado. No entanto, as propostas feitas para dinamizar a área, tanto a Operação Urbana Centro como a Operação Urbana Anhangabaú, não conseguiram atrair os investidores, como se esperava. A maior vantagem apropriada por eles foi a possibilidade de transferência do excedente do potencial construtivo de imóveis tombados para locais com maior dinâmica imobiliária. Ou seja, o potencial não foi implantado na própria área. A grande maioria da transferência do potencial construtivo foi efetuada para áreas fora do perímetro da operação urbana, onde o mercado imobiliário possui mais interesse em investir, pois trazem um retorno mais rápido. Quer dizer que o instrumento não está sendo utilizado como forma de dinamizar o Centro, mas sim de reforçar investimentos para o mercado imobiliário, comprometendo ou desviando o objetivo da operação e acentuando as desigualdades e a segregação entre áreas da cidade.

Outras Operações Urbanas foram propostas para renovar o Centro ou darIhe uma cara "mais nobre", menos pobre. Diante da ineficácia da legislação de operação urbana no Centro, o que se pode esperar, por exemplo, da Operação Urbana Parque D. Pedro II? Ela poderia, talvez, atingir o Pari, promovendo empreendimentos habitacionais e recuperando o aspecto de abandono da área. $\mathrm{A}$ própria legislação de uso e ocupação do solo, estabelecida após o novo Plano Diretor de 2002, prevê a criação de Zonas Especiais de Interesse Social (ZEIS) em áreas de maior concentração de cortiços, objetivando a diminuição de habitação subnormal.

A implantação de transportes de massa é também um investimento que traz retorno concreto. O funcionamento da linha 4 do metrô, que parte da Vila Sônia (Zona Oeste do município) e chega à Luz, será mais um investimento público que poderá resultar em alguma mudança substancial para o Centro. Há, ainda, a proposta de abertura de uma via paralela à Marginal Tietê - lei de 1978 , que passaria dentro do distrito do Pari; esse projeto está previsto, também, no Mapa do Sistema Viário Estrutural da lei $n^{\circ}$ 13.886/04, anexo ao Livro XXV (PRE). 
Ele compreende a construção de uma via elevada, alargamento de várias ruas e abertura na passagem da ferrovia que separa o Brás do Pari ligando os dois trechos da Rua Monsenhor de Andrade (mapa). Esse trajeto seria uma alternativa à passagem pelo Largo da Concórdia para o tráfego da Zona Leste. A lei foi promulgada há mais de 30 anos, e a demora em sua implantação mostra que, apesar das intenções de remodelar o Centro, na prática quase nada é efetivado.

A importância do Centro no contexto metropolitano e na formação e funcionamento da cidade de São Paulo é ímpar, fato que se pode perceber nas pesquisas "Origem e Destino" (OD) elaboradas pelo Metrô desde 1967. A configuração radioconcêntrica da estrutura da metrópole exerce sobre o Centro um peso com enormes contradições: problemas por um lado e atendimento às necessidades do município por outro. Ele atende a mais de 250 linhas de ônibus, 14 Estações de metrô e trens metropolitanos. A integração entre os diversos modos de transporte coletivo faz com que a área possua um intenso fluxo de pedestres para transbordo, o que, somando-se os trabalhadores e usuários da região, resulta num volume enorme de pessoas, superior a 6.000 por hora ${ }^{6}$.

Considerando-se a área central como o Centro Histórico da cidade, do ponto de vista funcional essa área continua com uma importância muito forte, apesar de a centralidade da metrópole ter-se expandido para a direção sudoeste. Embora o Centro Histórico tenha perdido peso econômico como atratividade imobiliária, a concentração da atividade financeira continua intensa, além de grande atividade do setor comerciário de padrão popular e o dinamismo do setor terciário.

O Estado tem tentado criar um novo dinamismo para a área, desde 1990, ao retornar seus órgãos e empresas públicas, tanto municipais como estaduais, para o Centro Histórico, com a finalidade de atrair pessoas de classe média para o local, proporcionando um novo uso e demandas para a área. Com grande oferta de trabalho, a região da Sé concentrava, em 1997, 195.000 empregos (quase $8 \%$ da oferta paulistana), dos quais 34.000 no comércio e 140.000 nos serviços; os dez distritos centrais reuniam quase 600.000 postos de trabalho (praticamente

\footnotetext{
${ }^{6}$ NAKANO, K., CAMPO, C. M., ROLNIK, R. Dinâmicas dos subespaços da Área Central de São Paulo. Em Caminhos para o Centro: Estratégias de Desenvolvimento para a Região Central de São Paulo , 2004.
} 
$25 \%$ da oferta do município) (Pesquisa OD 1997) ${ }^{7}$. Em 2007, os empregos no setor secundário somavam 90.968, no terciário 908.497, com um total de 1.000.180 postos de trabalho (Pesquisa OD 2007).

Um importante resultado da pesquisa “Origem e Destino" de 2007 é a recuperação da participação em viagens por transporte coletivo na metrópole, com acréscimo em todas as sub-regiões. A sub-região Centro apresenta desempenho similar à da metrópole: $56 \%$ para modo coletivo e $44 \%$ para modo individual. A evolução das viagens motorizadas por modo principal mostra pequeno acréscimo de participação do metrô, enquanto que o trem e o sistema ônibus praticamente mantêm o nível maior de participação. A maior participação em 2007 é a do automóvel, 41\%, embora com participação menor que em 1997, quando atingiu $47 \%$. Com relação às viagens por modo coletivo com transferências, merece destaque a sub-região Centro, onde o número de viagens sem transferências, ou seja, com um único modo, diminuiu de 69\% em 1997 para $60 \%$ em 2007. Nessa sub-região, o número de viagens com apenas uma transferência representa 31\%, com duas transferências, $8 \%$ e com três transferências, 1\% (Pesquisa OD 2007).

No Centro verifica-se uma especialização de espaço, que resulta em economia de aglomeração. As atividades combinam vantagens de polarização setorial com a localização central. Exemplos: o pólo financeiro no Centro antigo; lojas de artigos religiosos na baixada do Glicério; eletro-eletrônicos na Rua Santa Ifigênia; confecções no Bom Retiro e no Brás; tecidos, acessórios e artigos de armarinho na Rua 25 de Março; máquinas e equipamentos na Rua Florêncio de Abreu; materiais para restaurante e bares na Rua Paula Souza; automóveis, peças e acessórios em Campos Elíseos; companhias aéreas e agências de turismo na Avenida São Luís; lustres e luminárias a Rua da Consolação; artigos e restaurantes orientais na Liberdade; atacadistas de roupas populares e utensílios domésticos no Pari. O Centro é hoje utilizado pela população de mais baixo poder aquisitivo e seus espaços são ocupados pela estratégia de sobrevivência dos segmentos empobrecidos - sem-teto, ambulantes, desempregados, moradores de ruas e demais setores mais carentes dos circuitos produtivos formais.

\footnotetext{
${ }^{7}$ Companhia do Metropolitano de São Paulo - Metrô.
} 
A criação de outros centros em São Paulo não foi por falta de atividades econômicas ou dinamismo social do Centro Histórico, foi antes uma mudança de perfil de seus usos e usuários. Em geral as atividades mais sofisticadas e culturais (cinema, teatro, museus) foram sendo transferidas para áreas de uma clientela de maior renda e mais disponível a assuntos culturais. Todas as novas casas de shows e teatros "chiques" são inauguradas sempre no setor sudoeste da cidade e cada vez mais longe do Centro e mais perto da "cidade global" - a região da Marginal Pinheiros e da Avenida Luis Carlos Berrini. Há 40 anos os investimentos em sistema viário e de transporte são canalizados para o setor sudoeste do município, sendo o Centro antigo relegado a um processo de abandono "natural". No entanto, a área central da metrópole não deixa de ser um valioso patrimônio material e cultural da população paulistana, mesmo com a criação de centros novos mais ricos.

\section{3.c - Os bairros centrais}

Discorrer sobre os distritos centrais da metrópole (Sé, República, Consolação, Santa Cecília, Bom Retiro, Pari, Brás, Cambuci, Liberdade, Bela Vista)

é tentar montar um quebra-cabeça de histórias da ocupação do espaço metropolitano, eventualmente entretecidas com sobreposições de práticas sociais concorrentes ao longo do tempo. Muitas vezes um bairro se sobrepõe a outros, confundindo-se suas histórias e seus limites. Na origem desses bairros centrais teve grande peso a implantação de uma paróquia. A igreja toma conta do lugar, se faz presente, para depois surgir o loteamento ou se fragmentarem antigas chácaras em áreas menores para serem alienadas. No entanto, as transformações acontecem em virtude de fatores contingenciais, tornando-se relativos por dependerem das ações do poder público. Assim, cada bairro se desenvolve em função de uma peculariedade temporal e espacial. Ao relatar a história desses distritos, tomamos como parâmetro para análise seus limites atuais e os 
transportamos a sua gênese, de forma a poder construir sua formação através do tempo.

Antes de concluir pela estagnação ou não dos bairros centrais, convém relatar resumidamente seus desempenhos urbanos. A arquiteta Regina Meyer afirma em texto publicado pela entidade Viva o Centro que:

A estagnação desses bairros, ao mesmo tempo que favoreceu uma compartimentação no território da Área Central, acentuou descontinuidades entre esta e determinados setores da cidade (MEYER, Viva o Centro).

À luz de alguns dados podemos nos inclinar pela tese de que os bairros centrais são estagnados. Mas, diante da quantidade de empregos e de viagens atraídas e produzidas na área, podemos afirmar o contrário: a dinâmica expressa pelos números, os maiores de todas as regiões da metrópole, não os caracteriza como áreas estagnadas.

Com uma ocupação antiga, o Centro ao longo do tempo foi objeto de grandes intervenções viárias por meio das quais se alterou a morfologia do traçado e da paisagem construída. Os elementos estruturais de caráter metropolitano e o enorme número de atividades diversas sustentam e alimentam sua característica de centralidade. O grande número de imóveis de valor histórico e cultural traz por um lado uma singularidade no tratamento da paisagem urbana e, por outro, eleva a atenção na maneira de tratar esse patrimônio. Com inúmeros imóveis vazios, o Centro é uma potencial área de adensamento habitacional para a população de baixa e média renda, que teria assim o privilegio de morar perto do emprego e a chance de ir a pé ao trabalho ou de ter acesso a 14 estações de metrô, 3 estações ferroviárias e 250 linhas de transporte. O número de empregos é de mais de 1 milhão. Abriga quase 500.000 habitantes, apesar de nos últimos 30 anos a população moradora vir decaindo drasticamente. É usufruído diariamente por mais de 2 milhões de pessoas vindas de todos os pontos da cidade e da Região Metropolitana. Toda essa constituição possui uma relação indispensável ao funcionamento da metrópole. 
Para melhor analisar a situação atual dos distritos e poder compará-los, recorremos à Pesquisa OD 2007 em comparação com a de 1997 e os dados do IBGE, sintetizados pelo Departamento de Informação da Secretaria Municipal de Desenvolvimento Urbano (SMDU/PMSP, antiga SEMPLA).

Em breve análise dos dados do resumo da pesquisa OD 2007, além da recuperação da participação das viagens por modo coletivo, a pesquisa expõem os dados de domicílios, famílias, população, matrículas escolares, automóveis particulares, viagens produzidas, viagens atraídas e área total. Os distritos centrais se comportam de forma quase sempre semelhante. Podemos abreviar a análise da área central, do seguinte modo:

- $\quad$ O distrito de Santa Cecília possui maior número de domicílios, população e automóveis particulares.

- $\quad$ O distrito da República é o que possui maior viagens produzidas e atraídas, e, também, empregos.

- $\quad$ O maior distrito em área é o Bom Retiro.

- O distrito com o menor número de domicílios, família, população, emprego e viagens atraídas e produzidas é o Pari.

- $\quad O$ distrito da Sé é o menor em número de automóveis particulares e em área (tabela 21). 
Tabela 20 - Dados gerais - Pesquisa OD 2007 - Distritos da área central do Município de São Paulo

\begin{tabular}{lccccccccc}
\multicolumn{1}{c}{ Distrito } & Domicllios & Famillias & População & $\begin{array}{c}\text { Matrículas } \\
\text { Escolares }\end{array}$ & $\begin{array}{c}\text { Empregos } \\
\text { Auto Part }\end{array}$ & $\begin{array}{c}\text { Viagens } \\
\text { Produzidas }\end{array}$ & $\begin{array}{c}\text { Viagens } \\
\text { Atraídas }\end{array}$ & área (ha) \\
Sé & 6.485 & 6.485 & 16.837 & 14.047 & 167.135 & 1.223 & 336.217 & 337.400 & 219 \\
República & 19.374 & 20.495 & 43.080 & 14.764 & 201.619 & 5.425 & 358.767 & 360.760 & 231 \\
Bom Retiro & 7.083 & 7.774 & 22.035 & 20.638 & 78.939 & 3.626 & 163.941 & 165.435 & 424 \\
Pari & 4.271 & 4.377 & 13.104 & 13.130 & 28.512 & 2.190 & 72.759 & 73.918 & 271 \\
Brás & 7.741 & 7.741 & 22.192 & 12.405 & 74.999 & 4.245 & 153.169 & 154.436 & 365 \\
Cambuci & 8.493 & 8.674 & 25.415 & 9.491 & 38.860 & 5.940 & 98.616 & 98.337 & 395 \\
Liberdade & 20.422 & 20.884 & 54.245 & 66.233 & 63.115 & 14.145 & 230.622 & 231.596 & 367 \\
Bela Vista & 24.882 & 25.623 & 59.280 & 22.554 & 142.272 & 14.165 & 295.981 & 295.210 & 277 \\
Consolação & 19.456 & 19.481 & 47.563 & 53.344 & 109.187 & 15.890 & 268.698 & 271.308 & 379 \\
Sta Cecília & 25.438 & 25.463 & 63.531 & 30.512 & 95.543 & 16.351 & 235.649 & 233.785 & 372
\end{tabular}

Fonte: Pesquisa Origem Destino 2007, Companhia do Metropolitano de Săo Paulo.

No Pari, segundo dados sobre equipamentos sociais do sítio I nfocidade da Secretaria Municipal de Desenvolvimento Urbano (SMDU), o número de salas de teatros, shows e equipamentos esportivos mostra que o distrito continua dentro da média dos distritos do Centro. Ele apresenta menor quantidade em número de estabelecimentos e empregos em comércio varejista de produtos alimentícios. Dos domicílios ligados à rede de esgoto, à de telefonia e outros servidos por rede elétrica, o Pari possui a melhor posição entre todos os outros distritos do Centro.

As histórias dos 10 distritos centrais, que se formaram junto com a urbanização da cidade, no fim do século $X I X$ e começo do século $X X$, são bastante semelhantes. Para levantar e pontuar os pontos conflitantes e convergentes da formação desses bairros, faremos um breve histórico de cada um.

\section{Bela Vista}

O bairro da Bela Vista, também chamado de Bexiga, está localizado a sudoeste do núcleo central (distrito da Sé). Seu surgimento se deu entre 1789 e 1792, antes de São Paulo começar a se urbanizar, quando nem as ferrovias haviam ainda sido implantadas. Em 1880, o bairro começou a ter uma feição de 
cidade, com ruas estreitas e tortuosas; no entanto, a área tornou-se ocupada, realmente, em 1920, aglutinando-se ao restante da cidade.

A população da Bela Vista foi formada inicialmente por negros libertos e italianos pobres, que Ihe deram uma feição em que predominavam moradias de baixa e média renda e negócios diversificados de pequeno porte. Com o passar do tempo, o bairro se tornou um espaço de muitos restaurantes e bares, com vida noturna ativa. É um dos poucos bairros da cidade que permanece diuturnamente em atividade. Possui a maior densidade demográfica entre os distritos do município (243,04h/ha), posição que apresenta desde 1950.

\section{Bom Retiro}

Rumo ao norte do núcleo primitivo e limitando-se a leste com o rio Tamanduateí e ao norte com o rio Tietê, o Bom Retiro já era ocupado por chácaras de retiro, no século XIX. Na década de 1880 a 1890 iniciou-se o processo de loteamento do bairro. Ali se instalaram primeiro uma olaria e depois fábricas e uma escola de ensino primário. Logo, os imigrantes italianos procuraram o bairro para morar, depois os judeus e, ainda mais tarde, sírios, libaneses, turcos, russos e outras nacionalidades em menor escala. Com a inauguração da Estação da Luz, em 1867, o bairro expandiu-se comercialmente. Os serviços públicos foram desde o início beneficiados pela proximidade com os Campos Elíseos, onde a sede do governo do Estado permaneceu por um bom tempo. Já na última década do século passado, passou a ser o bairro de eleição dos imigrantes coreanos.

No distrito do Bom Retiro está localizado o Convento da Luz, precioso documentário da época quinhentista de São Paulo. O bairro se desenvolveu na medida em que o Jardim da Luz, aberto ao público em 1838, ganhou significação social. Lá se instalaram várias faculdades, residências de classe média, escritórios e consultórios, algumas pequenas indústrias, comércio e diversos prédios públicos. 


\section{Cambuci}

Ao longo do Caminho do Mar, ao sul do núcleo central, no Cambuci, casas de pequeno comércio e hospedagem atendiam e acolhiam os viajantes. Em 1883, o distrito foi palco da construção da I greja Nossa Senhora da Glória. E, em 1889, recebeu a primeira linha de bonde com tração muar.

Sua situação de fácil acesso, próximo ao Centro e com terrenos de baixo preço, estimulou a construção de fábricas, oficinas e muitas indústrias, a partir do final do século XIX. Sempre houve um comércio ativo a partir do seu centro, o Largo do Cambuci, e através dos seus corredores principais, as ruas convergentes. Em 1920, foi loteada a Vila Monumento e em 1930, o alto do Cambuci.

Grande comunidade de espanhóis e italianos, o Cambuci foi um bairro onde predominaram trabalhadores assalariados e prestadores de serviços diretos, diaristas, tarefeiros e os ambulantes. Suas ruas, nas proximidades das fábricas, eram movimentadas por pessoas que preenchiam os dois turnos de trabalho.

\section{Consolação}

O sítio do Capão se estendia do Largo do Piques (Largo da Memória) até o espinhaço do Araçá (Avenida Dr Arnaldo) e começou a ser parcelado em 1891. Seus limites geográficos eram com o rio Anhangabaú, localizado a oeste do núcleo primitivo da Sé. O desenvolvimento do bairro se deu em função da instalação da igreja da Consolação a 300 metros do Largo do Piques.

Em 1894, a Rua da Consolação era preenchida por moradias de média e alta renda até as proximidades da Rua Maria Antonia. Muitos imigrantes foram morar na Consolação. Em 1884, um novo loteamento deu origem a Higienópolis, parte do distrito. Os usos predominantes foram moradias, com grande destaque para a instalação da Santa Casa de Misericórdia, criada em 1884, e a Universidade Presbiteriana. 


\section{Liberdade}

Situada a sudeste do núcleo central, a Liberdade se caracteriza por ter sido ocupada pela colônia oriental integrado por japoneses, chineses, coreanos e vietnamitas.

O bairro se estruturou nas terras do cacique $\mathrm{Caiubi}^{8}$, às margens de uma estrada ou caminho na direção de Santo André da Borda do Campo e do Caminho do Mar. No fim do século XIX, já havia muitas chácaras com plantação de chás e jabuticabas. Foi o retalhamento dessas propriedades que resultou no bairro da Liberdade.

Em 1883, o distrito da Sé compreendia duas áreas distritais: a do norte e a do sul, a Liberdade. Em 1919 foi aprovado o plano de alinhamento da Rua Conselheiro Furtado, mas o bairro começou realmente a se estruturar e em 1930, com a abertura da Avenida 23 de Maio, no vale do Itororó.

Quando os imigrantes começaram a se instalar no bairro, primeiramente os italianos, seguidos dos portugueses e, mais recentemente, dos orientais, iniciouse o processo de transformação local. A Liberdade tem a maior população flutuante da cidade, em particular no período noturno, devido ao grande número de estudantes e professores de suas escolas e faculdades. É um bairro com usos mistos.

\footnotetext{
${ }^{8}$ Chefe Caiubi, irmão de Tibiriçá e Piquerobi, do agrupamento do rio Jeribatiba (Jurubatuba). O cacique, um dos primeiros itahyenses - por assim dizer -, foi batizado com o nome de João, auxiliando Tibiriçá na tarefa de criar a futura São Paulo, além de exercer domínio sobre as tribos das terras da Serra do Paranapiacaba e o litoral. Abandonou suas terras em 1554 para morar ao lado dos jesuítas em Tabataguera (Tabatinguera), reinando às margens do Jeribatiba

Foi ele que cedeu alguns dos seus guerreiros para formar vários aldeamentos em toda a extensão desse rio afluente do Tietê, incluindo-se o aldeamento Itaí na margem direita do Jurubatuba (Pinheiros), quando da formação do Sítio dos Pinheiros, em 1560, essa aldeia indígena estava localizada justamente onde hoje são as terras da Casa Bandeirista. (Hélcias Bernardo de Pádua 9/4/2008 O nosso Cacique Caiubi http://www.saopaulominhacidade).
} 


\section{República}

A República pertenceu originalmente ao distrito da Sé. Hoje está situada dentro da rótula central. Na primeira metade do século XIX, o espaço hoje ocupado pela Praça da República era uma vasta área, distante do centro da cidade, ou seja, do triângulo (ruas São Bento, Direita e XV de Novembro). Era usada para exercícios militares e depois como praça dos curros (praça onde havia corrida de cavalos e touros). Com a Proclamação da República, o espaço tornouse Praça da República.

A praça foi remodelada em 1905 e em 1912 foi inaugurado o coreto do jardim. A partir de 1940, várias alterações ocorreram no seu entorno. Com a implantação do sistema viário de Prestes Maia, também surgiram novos edifícios, como o edifício Esther, depois o edifício I tália.

O distrito se estende do elevado Costa e Silva até o Vale do Anhangabaú no sentido leste-oeste e da estrada de ferro até a Radial Leste no sentido norte-sul. Com uma ocupação de usos mistos desde sua origem, ela hoje prevalecem os usos não residenciais.

\section{Santa Cecília}

Santa Cecília, com área de 390 ha, estende-se do Elevado Costa e Silva à Marginal Tietê, a noroeste do núcleo central. Faz limite com o distrito da Consolação e com o Bom Retiro e a Barra Funda.

O distrito nasceu no Largo do Arouche, como uma natural expansão do Caminho de Pinheiros, a partir de 1808. Em 1847 foi inaugurada a Igreja de Santa Cecília, ponto central do bairro. Inclui o bairro de Campos Elíseos, que foi uma área privilegiada pela instalação da sede do Governo do Estado e de mansões a sua volta. Distrito de classe média, Santa Cecília resume o ecletismo arquitetônico da cidade de São Paulo. Ao caminhar por suas ruas podemos encontrar construção inspiradas em várias épocas e nacionalidades. O arruamento da chamada Cidade Nova atraiu muitos interessados na época em que as datas estavam sendo distribuídas, porém, aos poucos, o entusiasmo arrefeceu. A dificuldade de 
ocupação da região vinha do fato de só ser acessível para quem vinha do centro da cidade.

É uma área com predominância residencial, com usos de serviços especializados e pouco comércio.

\section{Sé}

O bairro da Sé foi a semente inicial da cidade de São Paulo. A vila se compunha do Pátio do Colégio e do triângulo formado pelas ruas São Bento, Direita e XV de Novembro. No século XVII, tinha por limites os conventos de São Bento, Carmo e São Francisco com seus respectivos largos. Em 1828 foi instalada a Academia de Direito numa sala da sacristia da Igreja de São Francisco. As ordens religiosas desempenharam especial influência na formação do bairro.

A Praça da Sé nasceu a partir do Largo da Sé, surgido na segunda metade do século XVI. Ali, no mesmo período, teve início a construção da Igreja Matriz, finalizada no início do século XVII. Em meados do século XVIII ela foi demolida e deu lugar a outro templo. Em 1911, todo o local veio abaixo para a construção de uma nova praça, muito maior, e da catedral, inaugurada em 1954. No início da década de 1970 a Praça da Sé passou pela maior reforma até então, para a implantação da estação do Metrô, inaugurada em 1978.

Como a Sé foi o núcleo da cidade, sempre houve todo tipo de usos: comércio, serviços, edifícios públicos, religiosos e institucionais. Teatros e cinemas. Os moradores foram paulatinamente se mudando para áreas mais residenciais, até o bairro tornar-se totalmente não residencial. Ele se estende da Avenida Prestes Maia (Vale do Anhangabaú) até o rio Tamanduateí, sentido lesteoeste; e da Radial Leste à estrada de ferro, sentido norte-sul.

\section{Brás}

O Brás nasceu numa parada do caminho para a freguesia de Nossa Senhora da Penha (a Paragem da Penha) e, depois, para a capela do Bom Jesus dos Matosinhos. Localiza-se a leste do núcleo central. 
O crescimento do bairro não seguiu um plano de arruamento, e suas ruas foram sendo abertas irregularmente, apresentando larguras variáveis conforme o lugar. A divulgação de um plano de loteamento de terrenos apareceu em 1832. A partir de então os loteamentos começaram a ser aprovados para sua execução.

Em meados do século XIX, a fisionomia da cidade de São Paulo começou a se alterar profundamente e, em 1867, com a inauguração da São Paulo Railway, o Brás espalhou-se devido a sua situação de passagem e às oficinas de seleiros, fabricantes de arreios, cangalhas e estribos. No entanto ele ainda era bastante despovoado e com características rurais. O problema das inundações do rio Tamanduateí, que alagavam a Rua do Brás e chegavam até o Largo da Concórdia, era um constante obstáculo a seu crescimento. A maioria das casas era no alinhamento, sem jardins, pobres e humildes. Passou a desenvolver-se rapidamente após a chegada dos imigrantes italianos e o surgimento da atividade industrial, com fábricas de todos os tipos, máquinas aperfeiçoadas, aparelhamento elétrico ou a vapor.

A partir da década de 1940, ocorreu no bairro uma constante e progressiva entrada de nordestinos, na mesma medida em que diminuía a presença dos italianos. Com o correr o tempo o Brás foi perdendo a característica italiana, dando lugar ao comércio nordestino. Foi o primeiro bairro comercial de São Paulo.

\section{Pari}

O distrito do Pari está localizado a nordeste do Centro Histórico do município. O primeiro parcelamento se deu após 1870, mas só passou a desenvolver-se com feições urbanas a partir de 1924, com os loteamentos oficiais. No início, a atividade principal era a das olarias do entroncamento dos rios Tietê e Tamanduateí. Depois, diversas fábricas foram implantadas. Com o passar do tempo outros usos foram sendo introduzidos, como comércio, serviços e equipamentos públicos, além de moradias de baixo e médio padrão.

O traçado de suas ruas ora se apresenta retangular, ora estreito e tortuoso. A população originária era portuguesa, mas logo os italianos e demais imigrantes escolheram o Pari para morar. A maioria da população era pobre, formada por 
trabalhadores das indústrias locais ou do Brás. Hoje, o Pari apresenta uma grande diversidade de uso.

Resumida a história dos bairros centrais podemos afirmar que hoje, os distritos localizados na área central vêm tendo processos bastante semelhantes. São distritos de moradores de baixa e média renda, com uma população mais idosa de descendentes de imigrantes. Os usos são diversificados, com predominância de habitação nos distritos localizados a oeste do núcleo central. Os distritos se estendem em áreas que variam de 219 (Sé) a 424 ha (Bom Retiro). A densidade demográfica vai de 51,2 (Pari) a 243,04 hab/ha (Bela Vista)

A história do crescimento da metrópole iniciou-se no núcleo primitivo (Sé, São Bento e Pátio do Colégio), que foi sendo parcelado nas sucessivas glebas que foram sendo loteadas e incorporadas ao núcleo central. Esses parcelamentos não foram planejados, aconteciam na medida da necessidade de novas ocupações, de forma que suas vias não se encontravam com as dos outros loteamentos que estavam sendo executados, distanciando-se cada vez mais do núcleo central e originando um caos reticulado independente e desencontrado. Ao longo dos anos os parcelamentos foram reconstruídos várias vezes sobre o mesmo quadro viário. 
Tabela 21 - Comparação das Histórias dos Bairros Centrais

\begin{tabular}{|c|c|c|c|c|c|}
\hline & Bela Vista & Bom Retiro & Cambuci & Consolação & Liberdade \\
\hline Localização(1) & Sudoeste & Norte & Sul & Oeste & Sudeste \\
\hline Surgimento & 1789 & 1838 & 1883 & 1884 & 1883 \\
\hline Motivo $^{(2)}$ & Hospedagem & Olaria/Indústria & Hospedagem & Igreja & Hospedagem \\
\hline Urbanização & 1920 & 1890 & 1920 & 1920 & 1930 \\
\hline Loteamento & Estreito/Tortuoso & Retilíneo/Misto & Retilíneo/Misto & Retilíneo & Retilíneo/Misto \\
\hline População(3) & Negros/Italianos & Italianos Imigrantes & Italianos/Espanhois & Imigrantes & Orientais \\
\hline Classe $^{(4)}$ & Baixa & Baixa/ Média & Média & Média/Alta & média \\
\hline Usos origem & Misto & Misto/Industrial & Misto & Residencial/Outros & Misto \\
\hline Usos atuais & Misto & Misto & Misto & Residencial/Outros & Misto \\
\hline Densidade $^{(5)}$ & 243,04 & 66,50 & 95,05 & 147,36 & 167,23 \\
\hline \multirow[t]{2}{*}{ Área (há) } & 277 & 424 & 395 & 379 & 367 \\
\hline & República & Santa Cecilia & Sé & Brás & Pari \\
\hline Localização(1) & Centro & Noroeste & Centro & Leste & Nordeste \\
\hline Surgimento & 1889 & 1808 & 1554 & 1832 & \\
\hline Motivo $^{(2)}$ & Praça & Igreja & Fundação & Hospedagem & Olaria \\
\hline Urbanização & 1900 & 1910 & 1850 & 1890 & 1920 \\
\hline Loteamento & Retilíneo & Retilíneo & Estreito/Tortuoso & Irregular/Misto & Irregular/Misto \\
\hline População(3) & Portugueses & Imigrantes & Portugueses & Italianos & Portugueses \\
\hline Classe $\mathrm{e}^{(4)}$ & Média & Média & Média/Baixa & Baixa/média & Baixa \\
\hline Usos origem & Misto & Residencial/Misto & Misto & Misto/Industrial & Misto \\
\hline Usos atuais & Predio Não Residencial & Residencial/Misto & Não Residêncial & Misto/Industrial & Misto \\
\hline Densidade $^{(5)}$ & 207,47 & 182,51 & 95,79 & 71,88 & 51,52 \\
\hline Área (há) & 231 & 372 & 219 & 365 & 271 \\
\hline
\end{tabular}

(1)Localização em relação ao núcleo central

(2)O que ocasionou o surgimento

(3)População original

(4)Classe de renda dos moradores formadores do bairro

(5)(população/ha) Censo 2000 
Diante da necessidade de organizar a cidade, foram criados os distritos, que se efetivaram praticamente ao mesmo tempo, com exceção do distrito da Sé, já antecipadamente instituído. Os distritos podiam abarcar mais de um bairro, mas sempre o bairro principal nomeava o distrito. Cada um que se formava obedecia a uma razão específica. A causa mais comum de seus surgimentos foi uma conjunção entre a necessidade de hospedagem e a existência de uma igreja. Os loteamentos mais antigos possuíam ruas estreitas e tortuosas, os que surgiram da urbanização nascente possuíam forma regular e planejada. A população original foi basicamente de imigrantes em todos os bairros, com predominância das classes baixa e média. Os usos eram embrionariamente mistos.

Os bairros do Brás, Pari, Bom Retiro, Bela Vista, Cambuci, Liberdade formaram-se como bairros operários. Os da Consolação, República e Santa Cecília foram ocupados mais pelas classes média e alta. Bela Vista, Pari e Brás sempre foram considerados como de "nível inferior"; os da Zona Oeste, Consolação (Higienópolis), Campos Elíseos, como de "nível superior". Os bairros fabris e operários ocuparam o norte, o leste e o sul. No sudoeste ficaram os bairros residenciais de classe média e alta. Nas plantas da cidade datadas das primeiras décadas do novecentos é possível, mais ou menos, acompanhar a mancha da abertura das ruas. Enquanto o loteamento do bairro de Higienópolis foi planejado de maneira a oferecer as melhores condições de implantação às construções, a parte referente a Santa Cecília já tinha outra configuração, com lotes bastante estreitos, que só admitiam construções geminadas. Entretanto, a proximidade com Higienópolis e a atração de pessoas com maior poder aquisitivo foi se identificando cada vez mais com os bairros do vetor oeste do município.

Cada bairro possui uma especificidade marcante para seu desenvolvimento. A Estação da Luz representou o marco do desenvolvimento do bairro do Bom Retiro; a rede ferroviária São Paulo Railway Company marcou a transformação dos bairros que ladeavam seu caminho. A partir dos últimos anos de 1870, as áreas suburbanas da Zona Leste, ocupadas por chácaras, começaram a ser loteadas de modo caótico e cabia às autoridades tentar pôr em comunicação os loteamentos esparsos. Em 1874, abriu-se a via que uniria pela primeira vez os bairros da Luz e do Brás, até então localidades completamente isoladas uma da 
outra. Um pouco mais tarde, nas regiões vizinhas do Brás e do Pari - bairros em que se instalava a atividade fabril -, foram abertas outras ruas que se comunicavam com a Luz. Assim, paulatinamente, a cidade foi se conectando para originar a metrópole.

Santa Ifigênia foi o primeiro bairro organizado a surgir em São Paulo, em 1810, situado na bifurcação dos caminhos coloniais para Pinheiros e Luz. Devido ao desenvolvimento da economia cafeeira e à implantação do sistema de transporte ferroviário, as antigas chácaras foram dando lugar ao arruamento, às residências de fazendeiros de café, às fábricas, às lojas de comércio de roupas e também a hotéis e pensões para servir as estações da São Paulo Railway (1867) e da Sorocabana (1875). O ciclo de melhorias urbanas foi enfatizado por Prestes Maia, na década de 1940, com a efetivação do Plano de Avenidas, que deixou a área central toda urbanizada.

Os dados que podem medir a qualidade de vida dos atuais moradores da área foram selecionados e resumidos nas tabelas 23, 24 e 25.

Tabela 22 - Equipamentos públicos - Distritos da Área Central do Município de Sáo Paulo

\begin{tabular}{|c|c|c|c|c|c|c|}
\hline \multirow[b]{2}{*}{ Distrito } & \multirow[b]{2}{*}{ Saúde 2007} & \multirow[b]{2}{*}{ Esporte 2008} & \multicolumn{4}{|c|}{ Cultura 2006} \\
\hline & & & Biblioteca & Cinema & Museu & $\begin{array}{c}\text { Casa } \\
\text { de Show }\end{array}$ \\
\hline Bela Vista & $\begin{array}{l}2 \text { UBS/ } 1 \text { Hosp/ } \\
1 \text { Clin Odonto }\end{array}$ & 2 & - & 20 & 6 & 10 \\
\hline Bom Retiro & 1 UBS & 6 & - & - & 7 & 4 \\
\hline Cambuci & 1 UBS & 2 & - & - & 1 & - \\
\hline Consolação & Não Há & 3 & 2 & 14 & 5 & 17 \\
\hline Liberdade & 1 Hospital & 2 & 5 & 1 & 3 & 3 \\
\hline República & Não Há & 3 & 2 & - & 3 & 10 \\
\hline Sta Cecília & $\begin{array}{c}1 \mathrm{UBS} / 2 \mathrm{AMA} / \\
1 \mathrm{PS} / 1 \mathrm{DST}\end{array}$ & 2 & 1 & - & 1 & 6 \\
\hline Sé & $\begin{array}{c}\text { 1DST/ 1UBS/ } \\
\text { 1 AMA/ 1Centro }\end{array}$ & 2 & - & 3 & 11 & 2 \\
\hline Brás & 1 UBS & Não Há & - & - & 2 & - \\
\hline Pari & $1 \mathrm{UBS} / 1 \mathrm{AMA}$ & 7 & 1 & 10 & 2 & - \\
\hline
\end{tabular}


Tabela 23 - Terrenos vagos / Terrenos contaminados / cobertura vegetal - Distritos da área central do Município de São Paulo

\begin{tabular}{lccc}
\multicolumn{1}{c}{ Distrito } & $\begin{array}{c}\text { Terrenos Vagos } \\
\mathrm{N}^{\circ} \text { / Área } \mathrm{m}^{2} \text { 2008 }\end{array}$ & $\begin{array}{c}\text { Terrenos Conta- } \\
\text { minados } 2007\end{array}$ & $\begin{array}{c}\text { Cobertura Vegetal } \\
\text { Por habitante } 1999\end{array}$ \\
Bela Vista & $249 / 92.658$ & 7 & 0,11 \\
Bom Retiro & $377 / 69.633$ & 6 & 7,29 \\
Cambuci & $151 / 151.309$ & 8 & 2,25 \\
Consolação & $136 / 78.241$ & 8 & 11,46 \\
Liberdade & $230 / 99.170$ & 8 & 1,8 \\
República & $102 / 44.392$ & 4 & 0,24 \\
Sta Cecília & 111.927 & 20 & - \\
Sé & $164 / 40.943$ & 2 & 0,22 \\
Brás & $23 / 68.758$ & 2 & - \\
Pari & $119 / 60.612$ & 2 & 12,42 \\
\multicolumn{1}{c}{ Fonte: SEMPLA/DIPRO-Sitio Infocidade,2009 } & &
\end{tabular}

Tabela 24 - Taxa de alfabetizaçáo (2006) Distritos da Área Central do Município de Săo Paulo

$\begin{array}{ll}\text { Bela Vista } & 98,2 \\ \text { Bom Retiro } & 96,7 \\ \text { Cambuci } & 97,3 \\ \text { Consolação } & 99,1 \\ \text { Liberdade } & 97,9 \\ \text { República } & 97,9 \\ \text { Santa Cecília } & 98,4 \\ \text { Sé } & 96,1 \\ \text { Brás } & 96,6 \\ \text { Pari } & 97,2\end{array}$

Fonte: SEMPLA/DIPRO - Sítio Infocidade,2009 
A qualidade de vida dos habitantes pode ser avaliada por meio de índices que meçam as condições de vida da população levando em conta fatores como o acesso a equipamentos sociais, o bem-estar e a expectativa de vida. A qualidade de vida envolve também a relação cotidiana com outras circunstâncias da vida, como meio ambiente.

Do acesso a equipamentos sociais, as áreas centrais são bem servidas em comparação com a periferia geográfica da cidade.

Quanto ao índice de cobertura vegetal, a Organização Mundial de Saúde (OMS) estipula a quantidade mínima de 9 ha por habitante. Com exceção do Pari e da Consolação, todos os distritos ficam abaixo do necessário. E o Pari possui um bom índice de cobertura vegetal, proporcional a sua população. A quantidade de áreas verdes na área é ínfima, mas como existem vários campos de futebol, esse índice torna-se alto. A estatística indica a média geral, o que nem sempre reflete a realidade. Em Santa Cecília e Brás não há cobertura vegetal.

É, ainda, preocupante pensar que há muitos terrenos contaminados, sobre os quais estavam implantados postos de gasolina, em geral não tecnicamente adequados; esses terrenos não podem ser utilizados até sua completa descontaminação. O número de terrenos vagos e suas respectivas áreas mostram a possibilidade de adensamento, ou seja, de novas construções, moradias ou outros usos, contrariando os estoques de potencial construtivo ofertados para essas áreas definidos nos Planos Regionais do Município, os quais se encontram praticamente esgotados.

A taxa de alfabetização $(97,2 \%)$ demonstra uma qualidade acima do que se verifica na periferia e também acima da média do município $(95,41)$. 
Tabela 25 - Area Construída por Unidades Territoriais Município de Sáo Paulo e Distritos Municipais Centrais - Uso habitacional - 2007/ $2001 / 1991$

\begin{tabular}{|c|c|c|c|c|c|c|}
\hline $\begin{array}{l}\text { Unidade } \\
\text { Territoriais }\end{array}$ & A. C 2007 & A. C. 2001 & A C 1991 & $\begin{array}{l}\text { Acréscimo } \\
\text { A.C. } \% 7 / 01\end{array}$ & $\begin{array}{l}\text { Acréscimo } \\
\text { A.C. } \% 1 / 91\end{array}$ & $\begin{array}{c}\text { Acréscimo } \\
\text { A.C. } \% 7 / 91\end{array}$ \\
\hline MSP & 420.943 .894 & 394.796 .602 & 290.059 .818 & 6 & 26 & 31 \\
\hline Bela Vista & 6.661 .800 & 6.274 .703 & 5.550 .166 & 5 & 11 & 16 \\
\hline Bom Retiro & 3.371 .977 & 3.295 .260 & 3.051 .218 & 2 & 7 & 9 \\
\hline Brás & 3.807 .492 & 3.734 .000 & 3.286 .043 & 2 & 11 & 13 \\
\hline Cambuci & 3.140 .780 & 2.879 .432 & 2.728 .932 & 8 & 5 & 13 \\
\hline Consolação & 7.564 .074 & 7.221 .889 & 6.461 .386 & 5 & 9 & 14 \\
\hline Liberdade & 5.034 .115 & 4.599 .692 & 3.865 .751 & 9 & 14 & 23 \\
\hline Pari & 1.845 .831 & 1.821 .628 & 1.559 .789 & 2 & 13 & 15 \\
\hline República & 6.724 .763 & 6.744 .153 & 6.464 .585 & -1 & 4 & 3 \\
\hline Santa Cecília & 6.677 .629 & 6.406 .748 & 5.655 .216 & 4 & 11 & 15 \\
\hline Sé & 4.512 .136 & 4.462 .878 & 4.274 .109 & 1 & 4 & 5 \\
\hline
\end{tabular}

Pelo diagnóstico elaborado, o distrito do Pari não difere tanto dentre os bairros centrais. Contudo é taxado de bairro estagnado, é estigmatizado como bairro sem importância em comparação com os semelhantes do vetor oeste como: Bom Retiro, Santa Cecília, Consolação e Liberdade. A confrontação dos distritos centrais demonstra que o Pari está na média de qualidade. No entanto, ele é um distrito não atrativo para o mercado imobiliário.

Os fatores que contribuem para essa situação podem ser constatados na perda de população moradora, como foi demonstrado na tabela 2. O Pari é o distrito que mais perdeu população dentre todos os distritos centrais de 1980 a 2001. Também foi o distrito que teve menor número de lançamentos verticais tanto comerciais como residenciais, conforme tabela 19 e 20 , o que significa pouca atividade imobiliária, pelo menos na maior parte do distrito, lembrando sempre que essa afirmação não se aplica a rua Silva Telles e arredores em função do intenso comércio e proximidade com a área comercial do Brás. É o distrito que possui maior número de imóveis alugados do Município de São Paulo, com quase 50\% enquanto a média do município 
é de $23 \%$. Possui grande número de imóveis abandonados, fechados ou encortiçados. Os dados de área construída mostram um crescimento relativo se comparada aos outros distritos centrais entre 1991 a 2001, conforme tabela 26 e muito pouco em relação a 2001 a 2007. Quanto à renda por domicílio, que pode ser outro fator para caracterizar a população moradora, o Pari está entre os três mais pobres, sendo ultrapassado apenas pelo Brás e Sé (Tabela 27). Também podemos acrescentar que o Pari é o distrito que possui menor número de empregos e menor atração de viagens de todos os distritos centrais (Tabela 21).

Tabela 26 - Domicílios por Faixa de Rendimento, em Salários Mínimos Município de Sáo Paulo e Distritos Municipais Centrais - 2000

$\begin{array}{lccccccc}\text { Unidades } & \text { Até } 3 & >3 \text { a } 5 & >5 \text { a } 10 & >10 \text { a } 20 & >20 & \text { Total } & \% \text { até } 5 \\ \text { Territoriais } & \mathbf{6 5 6 . 5 1 7} & \mathbf{4 7 2 . 9 8 9} & \mathbf{7 7 8 . 3 9 5} & \mathbf{5 5 5 . 0 3 8} & \mathbf{5 3 2 . 3 1 9} & \mathbf{2 . 9 9 5 . 2 5 8} & \mathbf{3 8} \\ \text { MSP } & 1.500 & 957 & 2.577 & & 1.391 & 6.424 & 38 \\ \text { Brás } & 745 & 649 & 1.111 & 1.107 & 836 & 4.448 & 32 \\ \text { Pari } & \mathbf{1 4 . 8 4 4} & \mathbf{1 3 . 6 6 5} & 33.542 & 34.699 & \mathbf{4 3 . 9 2 1} & \mathbf{1 4 0 . 6 7 1} & \mathbf{2 0} \\ \text { Sé } & 2.068 & 2.236 & 5.761 & 6.624 & 8.044 & 24.734 & 17 \\ \text { Bela Vista } & 1.400 & 1.097 & 2.056 & 2.078 & 1.626 & 8.258 & 30 \\ \text { Bom Retiro } & 1.133 & 960 & 2.094 & 2.424 & 2.345 & 8.956 & 23 \\ \text { Cambuci } & 1.369 & 1.275 & 3.766 & 4.513 & 10.920 & 21.843 & 12 \\ \text { Consolação } & 2.370 & 2.129 & 4.747 & 4.898 & 7.874 & 22.017 & 20 \\ \text { Liberdade } & 2.721 & 2.481 & 6.559 & 5.593 & 3.636 & 20.991 & 25 \\ \text { República } & 2.355 & 2.137 & 6.104 & 6.905 & 8.667 & 26.168 & 17 \\ \text { Santa Cecilia } & 1.428 & 1.350 & 2.454 & 1.663 & 810 & 7.705 & 36 \\ \text { Sé } & & & & & & & 36\end{array}$

(1)Fonte: PMSP / SEMPLA / DIPRO / Infocidade.

O histórico de um bairro se faz através da pesquisa histórica, de sua formação geográfico-urbana e de sua estruturação político-social. A história reproduz e valoriza novas interpretações. Assim, sentimos com a pesquisa 
realizada. Um bairro manifesta os seus limites impessoais - é continente e conteúdo, é uma abstração qualificada.

Como diz Clovis de Athayde Jorge:

Um bairro não basta em si mesmo, porque não agrega num espaço determinado o conjunto anônimo de indivíduos de total suficiência. Ao contrário, é uma reunião orgânica que vive, expande ou se contrai com maior ou menor plenitude daqueles recursos (JORGE, s/d: 11).

A reflexão sobre a situação de um bairro inserido na metrópole pode ser identificada nas palavras de Seabra:

É por isso que, quando os bairros já não eram enquanto tal, espaços de representação, começaram a vagar pela sociedade as representações sociais dos bairros. E, exatamente, porque foram eles (os bairros) na história urbana, uma realidade empírica vivida que experimentou a fragmentação do espaço e do tempo. A partir de tais indagações se pode constatar que o curso da urbanização entre nós foi dilacerante. Que a formação social e política da Cidade com seus bairros serviu aos desígnios de uma vida urbana em formação e que a urbanização de São Paulo, se encarada de um ponto de vista lógico, já mostrava os seus limites dada a impossibilidade de reproduzir, em sincronia, todos os elementos \ momentos do seu próprio processo (SEABRA, 2005: 305).

A história é um processo temporal movido pelas contradições internas. A história das realizações do homem comum no espaço da cidade é um fator primordial da formação da concepção do espaço coletivo. É interessante perceber que a percepção do espaço está ligada à necessidade e à apropriação do espaço, ambas reflexos culturais. É sempre importante notar o processo das coisas, do cotidiano e seu movimento. Da reprodução automática, mimética da vida. 
Falar sobre os bairros operários e a história do homem que ali vive ou viveu não é prática corrente. A história quase sempre se preocupa com os grandes acontecimentos, os monumentos e os fatos que marcaram a história oficial, a história da classe dominante. Marx e Engels dizem:

A produção de idéias, de representações e da consciência está em primeiro lugar direta e intimamente ligada à atividade material e ao comércio material dos homens; é a linguagem da vida real. As representações, o pensamento, o comércio intelectual dos homens surge aqui como emanação direta do seu comportamento material. O mesmo acontece com a produção intelectual quando esta se apresenta na linguagem das leis, política, moral, religião, metafísica, etc., de um povo. São os homens que produzem as suas representações, as suas idéias, etc. e, para sermos precisos, os homens tais como são condicionados pelo modo de produção da sua vida material, pelo seu comércio material e o seu desenvolvimento ulterior na estrutura social e política. Mas os homens reais, atuantes e tais como foram condicionados por um determinado desenvolvimento das suas forças produtivas e do modo de relações que the corresponde, incluindo até as formas mais amplas que estas possam tomar. A consciência nunca pode ser mais do que o Ser consciente; e o Ser dos homens é o seu processo da vida real. E se em toda a ideologia, os homens e as suas relações nos surgem invertidos, tal como acontece numa câmara escura, isto é apenas o resultado do seu processo de vida histórico, do mesmo modo que a imagem invertida dos objetos que se forma na retina é uma conseqüência do seu processo de vida diretamente físico (MARX e ENGELS, s.d.:25 e 26).

E prosseguem mais adiante:

Não tem história, não tem desenvolvimento; serão antes os homens que, desenvolvendo sua produção material e suas relações materiais, transformam, com esta realidade que thes é própria, o seu pensamento e os produtos desse pensamento. Não 
é a consciência que determina a vida, mas sim, a vida que determina a consciência (idem:26).

E prosseguem, levando-nos a refletir sobre a cidade que construímos:

Os homens têm uma história pelo fato de serem obrigados a produzir a sua e de terem de fazer de um determinado modo: esta necessidade é uma conseqüência da sua organização física; o mesmo acontece com a sua consciência (idem: 35).

Diante da constatação que a história, na maioria das vezes, interpreta os fatos do ponto de vista da classe dominante, foi importante a pesquisa in loco, as entrevistas com os moradores, frequentadores e trabalhadores da área. O produto dessa troca nos fez compreender mais profundamente 0 espaço do Pari revelando como eles o apropriam. 


\section{Conclusão}

\section{4.a. Compreendendo a estagnação do Pari}

A estagnação urbana em uma área da metrópole, mais especificamente no distrito do Pari, foi o objeto do presente trabalho. Conforme a conceituação elaborada no capítulo 1 , foi entendido que se encaixam na definição de estagnadas as áreas que apresentam desvalorização imobiliária, pouca alteração dos usos do solo, grande número de habitações subnormais, como cortiços, e imóveis vazios e/ou abandonados, além de alto índice de violência e diminuição da atuação dos movimentos sociais (p. 32).

As primeiras impressões de estagnação no bairro foram apreendidas pela pesquisa in loco em algumas ruas e quadras, e indicavam serem elas motivadas pela deterioração de elementos urbanísticos, como habitações, galpões e edifícios diversos, ou de elementos da paisagem urbana, como praças e vias. Esses elementos do cotidiano nitidamente identificáveis revelaram o processo histórico de estagnação do bairro e foram as primeiras razões empíricas que nos levaram a tentar compreender o fenômeno da estagnação urbana.

O diagnóstico elaborado no capítulo 2 trouxe o reconhecimento da situação do distrito do Pari em 2006. A análise desse diagnóstico nos mostrou a importância da história como recurso fundamental para a compreensão do processo de constituição do espaço e da sociedade urbanos assim como de apreensão da dinâmica no/do espaço. As questões levantadas sobre a estagnação no Pari foram essenciais para demonstrar como o processo social se expressa no espaço, como veremos a seguir.

A concentração de imóveis nas mãos de um número pequeno de proprietários desempenha no capitalismo a função pela qual a renda da terra urbana ou a valorização da terra é apropriada pelos seus proprietários (2.f.III., p. 139).

A acumulação da propriedade privada imobiliária exclui uma grande parte da população moradora do acesso à moradia. Essa afirmação pode ser constatada pela grande porcentagem de locatários no bairro (Tabela 14, p. 144). 
Aventamos a possibilidade de que pode ter ocorrido a apropriação de terras devolutas, em face das inúmeras quadras apropriadas por particulares em áreas de várzea ou até mesmo do leito original do rio Tietê. E, sobretudo, porque isso foi verificado, em mapa da Prefeitura Municipal de São Paulo (Mapa 15), onde tais terras aparecem como pertencentes ao município e na realidade, são hoje ocupadas por particulares. Mas não há dados das transações imobiliárias verdadeiramente efetuadas, portanto não se pode afirmar categoricamente essa hipótese (2.a.II., p. 37).

Há depreciação dos valores venais nas áreas com menor investimento público, como no Canindé e desinteresse do mercado imobiliário. A maior valorização se deu nos locais onde há bastante disputa por imóveis rentáveis, como a Rua Silva Telles, lugar de grande procura pelo comércio atacadista, que abastece não apenas a metrópole, mas até mesmo o Brasil (2.f.IV., p. 162). A valorização ou desvalorização dos valores venais é acompanhada pelos preços do mercado de imóveis.

Podemos sustentar que 0 distrito do Pari apresentou valorização/desvalorização imobiliária, abordada no item 2.f.IV. Verificamos que nos distritos que fazem parte do Centro, o comportamento dos preços de imóveis foi semelhante ao do Pari. Contraditoriamente, alguns corretores do bairro sustentam que o movimento do mercado imobiliário, no Pari, é muito fraco em virtude do alto preço dos imóveis em relação ao bairro vizinho da Casa Verde.

A pouca atração do mercado imobiliário pelo bairro é constatada pelo baixo número de lançamentos imobiliários verticais, tanto comerciais como residenciais (Tabelas 18 e 19) (2.f.V., p. 175). Nessas mesmas tabelas, verificam-se que os bairros da Mooca, Água Rasa e Bela Vista foram os que mais tiveram lançamentos residenciais verticais.

O Pari apresenta, como demonstramos no capítulo 2.e, usos do solo que despertam pouca atenção da população e exercem pouca atividade econômica. A maior alteração de atividade urbana com a importante característica de funcionar como ponto de aglutinação de moradores foi a implementação de novas igrejas (coreanas, principalmente), por meio de reformas ou de novas construções (Foto 31, p. 147). 
Para exemplificar as atividades de pouca atratividade da população, numerosas no bairro, destacamos os pequenos bares de esquina, onde a frequência é relativamente baixa e não há variedade de mercadorias, conforme análise no capítulo 2.e.II. p. 93-108. Há pelo menos dois bares por quadra (Tabela 10, p. 76), que não apresentam o padrão representativo daqueles voltados para uma clientela de classe média e alta; são botequins com pouco ou nenhuma preocupação com a qualidade dos produtos e a higiene, onde em geral se vende pequena variedade de bebidas baratas e, às vezes, comestíveis. É o lugar de encontro de pessoas aparentemente desocupadas, em sua maioria homens. Localizados invariavelmente nas esquinas, são quase sempre de dimensão pequena e limpeza duvidosa. É difícil que nos lotes de esquina ocorram construções novas, especialmente se eles forem de pequena dimensão, em razão da exigência de recuo de ambos os lados. Assim, só cabe a implantação de edifícios que atendam essa exigência.

Ainda como exemplos de usos que desagradam os moradores, podemos relacionar as oficinas de automotores e os estacionamentos (Tabela 10). Além de serem barulhentos e provocarem intensidade de trânsito de veículos e de pessoas, no mais das vezes trazem pouca rentabilidade econômica ao bairro, como afirmaram alguns entrevistados. Os estacionamentos costumam ficar ociosos e provavelmente são áreas de reserva de valor, não cumprindo sua função social de guardar os veículos.

Apesar dessas atividades (ou falta delas) desagradarem os moradores vizinhos, elas conferem ao bairro uma diversidade de usos (apontada no capítulo 2.e. p. 107) que identifica sua integração à metrópole e traz uma demanda de frequentadores que movimenta sua economia. As combinações e misturas de atividades e usos do solo são fundamentais para promover vitalidade ao bairro, ao contrário da falta de atividades e separação de usos.

O Pari tem, ainda, vários imóveis vazios e/ou abandonados (fechados) (Tabela 10, p. 76). Esse alto índice de vacância se verifica tanto em imóveis de pequena dimensão quanto nas antigas fábricas e galpões. Há também imóveis fechados à espera de uma valorização muitas vezes irreal, na opinião de entrevistados. Assim, permanecem um 
tempo tão grande fechados que acabam por sofrer forte deterioração física e, eventualmente, até invasões. Além dos imóveis abandonados, há aqueles para alugar ou vender e os que estão em construção. Todos eles estão sem uso ou à espera de alguma intervenção que transforme seu estado inerte (Tabela 10). Sua concentração em determinadas áreas do bairro é bastante visível, em especial nas imediações da Rua João Teodoro, Avenida Cruzeiro do Sul, Marginal Tietê e áreas mais baixas da várzea do rio Tietê.

Da mesma forma, nas conclusões do capítulo 2.e.l., p. 92, pudemos verificar que o aumento do número de habitações subnormais, como cortiços, se deu sempre de forma lenta e contínua. No bairro há apenas duas favelas, toleradas de certa forma pela população local, por não interferirem diretamente no mercado de imóveis ou no cotidiano dos moradores. Em outras palavras, a localização das favelas é escondida o suficiente para não desagradar os compradores ou locatários de imóveis e atrapalhar a sociabilidade dos habitantes.

O número grande de cortiços também foi por nós considerado um indicador de estagnação urbana. Mais que o número absoluto de cortiços, a tendência de crescimento de habitações subnormais também foi considerado um parâmetro balizador para indicar o processo de estagnação urbana de um bairro.

O índice de violência no Pari, constatado no capítulo 2.b.ll., p. 63, é um dos mais altos do município (Mapa 11, p.65). A violência se configura como um elemento negativo na análise para qualificar uma área urbana. Ao pesquisar sobre o Pari nas páginas dos semanários e jornais diários, nos deparamos com o fato de o bairro ser notícia apenas nos cadernos policiais, estando ausente dos outros. Isso reforça nossa crença quanto ao seu esquecimento ou abandono por parte do poder público. Essa questão social é mais um fator a reforçar a imagem do Pari como um bairro estagnado.

Conforme entrevista com moradores, frequentadores e trabalhadores do bairro (capítulo 2.b., p. 53), constatamos que os movimentos organizados do bairro não têm tido mais a atuação de tempos atrás. Embora esse refluxo não tenha acontecido somente no Pari 
e seja um sintoma dos tempos atuais, essa fragilidade reforça a ideia de estagnação.

O Pari é o distrito que mais perdeu população moradora entre os distritos centrais, como pode ser verificado na tabela 2 do capítulo 2.c.l., p. 67. Além disso o distrito está dentre os três com menor renda do município, juntamente com Sé e Brás (Tabela 26, p. 233).

As afirmações anteriores induzem a considerar a existência de estagnação urbana no distrito do Pari, mesmo que ela não ocorra na totalidade do bairro e que os fatores de estagnação tenham estágios diferentes.

O conjunto dos fatores acima citados traz, de um lado, uma ideia negativa do bairro, ideia essa designada como de estagnação. Por outro lado, a diversificação de atividades lhe confere um clima dinâmico, que o qualifica de maneira positiva. A diversidade de atividades, usos do solo, de alturas, de padrão e de idade dos edifícios muitas vezes é criticada por revelar certa desordem, falta de uniformidade. A crítica parte de um modelo ideológico, da cidade homogênea, que considera agradável e atribui a ideia de disciplina à aparência uniforme. De outro ponto de vista, pode-se enxergar essa homogeneidade como monótona, entediante.

Pode-se considerar como aspectos negativos a sujeira e o desleixo de alguns usos, como ferros-velhos, oficinas descuidadas, bares, postos de gasolina sujos, estacionamentos, garagens de caminhões grandes e ônibus, imóveis fechados e abandonados, favelas em condições deterioradas, cortiços e vazios urbanos, como relatado no capítulo 2.e.l. e II., p.93. A concentração de alguns desses usos do solo numa determinada área causa uma imagem de abandono e pobreza. Assim como os usos que ocupam grandes terrenos isolados trazem uma impressão não agradável, pois impõem isolamento e seus espaços grandes quebram a continuidade da cidade. Como mostramos no capítulo 2.e sobre a história da ocupação, essas atividades contribuem para trazer insegurança, monotonia, dispersão e provocar desprezo pelo bairro, pois impedem um fluxo de pessoas ao longo do dia, isolam as relações entre moradores e não incentivam a aplicação de recursos econômicos na área.

Outros fatores negativos são os elementos que cortam o espaço, como linhas férreas, rios e avenidas com trânsito intenso e pesado 
(2.e.lll., p. 108). O bairro do Pari se confronta com o rio Tietê de um lado, de outro com o Tamanduateí e fica próximo à linha férrea. São três obstáculos que formam uma ilha e interferem no espaço público, seccionando-o, dificultando a circulação de pedestres, segregando uma parte da outra e impedindo a interação.

Esse retrato de uma área da metrópole, ora qualificada ora desqualificada, faz parte do seu movimento histórico. Ele acabou resultando num estigma de estagnação urbana. No entanto, a história do distrito do Pari nos mostra (como vimos no capítulo 2) que, no seu espaço, há estagnação e desenvolvimento ao mesmo tempo. O bairro se apresenta hoje como alternando fatos distintos e espaços diversos.

Concluímos que o Pari é um distrito provido de equipamentos públicos, de infraestrutura e localização boa e central disponível e não periférico. Mesmo assim não atrai o mercado imobiliário, porque concentra uma série de usos e atividades (como os mostrados no capítulo 2.e., p.74) associados às classes mais pobres e que o fazem ser tratado com menosprezo. Esse repúdio é de natureza ideológica, pois, mesmo que haja aspectos que revelem estagnação, como nos fenômenos relatados acima, não há nada de desprezível, errado ou condenável nisso. O que realmente acontece é que as atividades como bares, estacionamentos, oficinas mecânicas, imóveis abandonados, cortiços e favelas e, mais ainda, imigrantes pobres, religiões tidas como exóticas que são atividades e pessoas consideradas "marginais" pelo pensamento dominante. Chamar de estagnado é a maneira de expor um preconceito, ou seja, é uma forma ideológica de se referir ao bairro como inferior - uma mácula que carrega o desdém pelas classes mais pobres. Esse menosprezo das classes mais altas está ligado à população que elas consideram marginal, embora seja um contingente populacional importante na construção da cidade e da sociedade; no entanto o bairro ocupado por esse contingente é alvo da ideologia da estagnação como conceito pejorativo que contribui para desqualificá-lo.

O que realmente é desprezível é a situação da metrópole plena de injustiças sociais e espaciais, como mostramos no presente trabalho, traduzidas nos conflitos existentes no distrito do Pari. Por esse motivo é necessário fazer a crítica que desvende como é crucial a relação entre os 
aspectos estruturais do desenvolvimento desigual. Se de um lado, é verdade que a cidade é um espaço privilegiado de aglomeração de pessoas e de negócios onde se dá a produção de riqueza, também é verdade que nela se produz a pobreza e - como mostramos aqui - o preconceito e a opressão.

O presente estudo evidencia que a hegemonia e a fragmentação do espaço são obras do capital imobiliário e financeiro, que induz a uma nova dinâmica espacial, com uma flexibilidade, rapidez e mobilidade que tornam impossível uma atuação de resistência. A pecha de estagnação no Pari, embora secundária diante da magnitude da metrópole, é mais uma fronteira para a expansão e a reprodução do capital em um novo espaço. 


\section{Referências Bibliográficas}

AB'SABER, Aziz. Sítio Urbano de São Paulo in A Cidade de São Paulo - Estudos de Geografia Urbana vol.ı - A Cidade de São Paulo. Associação dos Geógrafos Brasileiros, Secção Regional de S. Paulo. São Paulo: Cia. Editora Nacional, 1958.

ABBAGNANO, Nicola. Dicionário de Filosofia. São Paulo: Ed. Marins Fontes, 1999. ARANTES, Otilia. O lugar da arquitetura depois dos modernos. São Paulo: Edusp, 2000.

. Urbanismo em fim de linha. São Paulo: Edusp, 2001.

ARENDT, Hannah. A condição humana. Rio de Janeiro: Forense Universitária, 1989.

AZEVEDO, Aroldo de. A cidade de São Paulo - Estudos de geografia urbana, vol. III. São Paulo: Companhia Editora Nacional, 1964.

AZEVEDO, Fernando. A cultura brasileira. São Paulo: Edições Melhoramentos, 1958.

BERMAN, Marshall. Tudo que é sólido desmancha no ar - São Paulo: Cia das Letras, 1986.

BONDUKI, Nabil. Habitar São Paulo: reflexões sobre a gestão urbana. São Paulo: Estação Liberdade, 2000.

Liberdade, 2002.

Origens da habitação social no Brasil. São Paulo: Estação

BOSI, Alfredo. Dialética da colonização - São Paulo: Cia das Letras, 2000.

BOSI, Ecléa. Memória e Sociedade - São Paulo: Cia das Letras, 1999.

. Memórias paulistanas. Estudos Avançados, v. 17, p. 198-210, São

Paulo, 2003.

BOTELHO, Adriano. O financiamento e a financeirização do setor imobiliário: Uma análise de produção do espaço e da segregação sócio-espacial através do estudo do mercado da moradia na cidade de São Paulo. São Paulo, 2005. Tese de doutorado (FFLCH) - Departamento de Geografia, Universidade de São Paulo.

BRANT, V. C. e KOWARICK, L. (coordenadores). São Paulo 1975, crescimento e pobreza. São Paulo: Edições Loyola, 1975.

BRAUDEL, Fernand. Escritos sobre a história. São Paulo: Editores Perspectiva, 1992.

BRITO, Mônica Silveira. A participação da iniciativa privada na produção do espaço urbano: São Paulo 1890-1911. São Paulo, 2000. Dissertação de Mestrado, Departamento de Geografia, FFLCH/USP, São Paulo.

CALDEIRA, Tereza. Cidade de muros. São Paulo: Editora 34 e Edusp, 2000.

CAMARGO, Cândido et al. São Paulo 1975: crescimento e pobreza. São Paulo: Edições Loyola, 1975. 
CAMARGO, LAMPARELLI, GEORGE. Nota I ntrodutória sobre a construção de um objeto de estudo: o urbano. São Paulo: Estudos FUNDAP № 1, 1980.

CARR, E. H. Que é história?. São Paulo: Editora Paz e Terra, 1996.

CARLOS, Ana Fani Alessandri (org.). Novos caminhos da geografia. São Paulo: Editora Contexto, 1999.

CARLOS, Ana Fani Alessandri. Espaço-tempo na metrópole - São Paulo: Contexto Acadêmica, 2001.

CARLOS, Ana Fani A. e OLIVEIRA, Ariovaldo U. Geografia de São Paulo: representação e crise da metrópole. São Paulo: Editora Contexto, 2004.

CARVALHO, Eduardo G. O negócio da terra . Rio de Janeiro: UFRJ editora, 1991.

CASTILHO, Ricardo Abid. A fragmentação da terra - Propriedade fundiária absoluta e espaço mercadoria no Município de São Paulo. São Paulo, 1993. Dissertação de Mestrado (FFLCH), Departamento de Geografia, Universidade de São Paulo.

CERTEAU, Michel de; GIARD, Luce e MAYOL, Pierre. A invenção do cotidiano. Petrópolis, RJ : Vozes, 1996.

CHAUÍ, Marilena. O que é I deologia? $12^{a}$ ed. São Paulo: Ed. Brasiliense, 1983. . Convite à filosofia. São Paulo: Editora Ática, 1998.

Brasil: mito fundador e sociedade autoritária. São Paulo: Fundação Perseu Abramo, 2000.

CHESNAIS, François. A Mundialização do capital. São Paulo: Xamã Editora, 1996. A Mundialização Financeira. São Paulo: Xamã Editora, 1999.

DAMIANI, A. L., CARLOS, A. F. A. e SEABRA, O. C. de L. (org.). O espaço no fim de século, a nova raridade. São Paulo: Editora Contexto, 1999.

DEAK, Csaba. A busca das categorias da produção do espaço. São Paulo, 2001. Tese de Livre-docência - FAU USP, São Paulo.

ENGELS, Friedrich. A origem da família, da propriedade e do estado. Lisboa: Editorial Presença, s. d.

FAUSTO, Boris. História do Brasil. São Paulo: Edusp, 2003.

FERREIRA, J oão Sette Whitaker. 0 mito da cidade-global. Petrópolis, RJ: Editora Vozes, 2007.

FIX, Mariana. São Paulo cidade global: fundamentos financeiros de uma mirage. São Paulo: Boitempo Editorial / ANPUR, 2007.

FERNANDES, Florestan. A revolução burguesa no Brasil. São Paulo: Editora Globo, 2006.

FERNANDES, Ana Cristina. Da reestruturação corporativa à competição entre cidades: Lições urbanas sobre os ajustes de interesses globais e locais no capitalismo contemporâneo. In Revista Estudos e Debates, ano XVII, n 41, 2001.

FURTADO, Celso. Subdesenvolvimento e estagnação na América Latina. Rio de janeiro: Ed. Civilização Brasileira, 1966. 
GOTTDIENER, Mark. A produção social do espaço urbano. São Paulo: Edusp, 1997.

GUNN, Philip. Espaço, estado, território: uma contribuição à analise da organização em São Paulo e no Brasil. São Paulo, 1986. Tese de doutorado, FAU, Universidade de São Paulo.

HARVEY, David. A justiça social e a cidade. São Paulo: Hucitec, 1980.

_. Los limites del capitalismo y la teoria marxista. México: Fondo de Cultura Económica, 1990.

A condição pós-moderna. São Paulo: Edições Loyola, 1993.

A cidade do capital. Rio de Janeiro: DP\&A editora, 1999.

. Espaços de esperança. São Paulo: Edições Loyola, 2004.

HELLER, Agnes. O cotidiano e a história. São Paulo: Paz e Terra, s.d..

IANNI, Octávio. I mperialismo e cultura. Petrópolis, RJ: Editora Vozes, 1976.

JACOBS, Jane. Muerte y vida de las grandes ciudades. Madri: Ed. Península, 1973.

JOHNSON, Allan. Dicionário de sociologia. Rio de Janeiro: Zahar Editor, 1998.

HOBSBAWM, Eric. Sobre história. São Paulo: Cia das Letras, 1998.

. A invenção das tradições. São Paulo: Paz e Terra, 2002.

HOUAISS, Instituto. Dicionário Houaiss. Rio de Janeiro: Editora Objetiva, 2001.

KANITZ, Stephen. A estagnação brasileira. Revista Veja, Editora Abril, edição 1857, ano 37, 9 de junho de 2004.

KOWARICK, Lúcio. A espoliação urbana. São Paulo: Paz e Terra, 1993.

KOWARICK, Lúcio (org.). As lutas sociais e a cidade. São Paulo: Paz e Terra, 1994.

LAMAPARELLI, C., CAMARGO, A., GEORGE, P. Nota Introdutória sobre a construção de um objeto de estudo: o urbano. Revista Estudos FUNDAP n 1 , São Paulo, 1978.

LANGUENBUCH, Jurgen R. A estruturação da Grande São Paulo - estudo de geografia urbana. São Paulo: Fundação IBGE, Ministério do Planejamento e Coordenação Geral, 1971.

LEFÈBVRE, Henri. Critique de la vie quotidienne II. Paris: L'Arche Éditeur, 1958. El derecho a la ciudad. Barcelona: Ediciones Península, 1968.

A re-produção das relações de produção. Porto, Portugal: Publicações Escorpião, 1973.

. Espacio y politica. Barcelona: Ediciones Península, 1976.

. A vida cotidiana no mundo moderno. São Paulo: Editora Ática, 1991.

A cidade do capital. Rio de J aneiro: DP\&A Editora, 1999 a.

A revolução urbana. Belo Horizonte: Ed. UFMG, 1999 b. 
La production de l'espace. Paris: Anthropos, 2000.

LEFÈBVRE, H. e GUTERMAN, N. La consciense mystifiée. Paris: Editions Le Sycomore, 1979.

LOJ KINE, Jean. O estado capitalista e a questão urbana. São Paulo: Editora Martins Fontes, 1981.

MARICATO, Ermínia. Metrópole na periferia do capitalismo: ilegalidade, desigualdade e violência. São Paulo: Hucitec, 1996.

MARQUES, E., TORRES, T. (orgs.). São Paulo - segregação, pobreza e desigualdades sociais. São Paulo: Ed. Senac, 2005.

MARTINS, José de Sousa. Exclusão social e a nova desigualdade. São Paulo: Paulus, 1997.

O cativeiro da terra. São Paulo: Hucitec, 1998.

MARTIN, André Roberto. A permanência da deterioração urbana como processo: o caso do bairro do Brás em São Paulo. In Geografia de São Paulo: Representação e crise da metrópole. São Paulo: Editora Contexto, 2004.

MARX, Karl. Manuscritos econômicos e filosóficos de 1844. México: Colección 70, Editorial Grijalbo S. A., 1968.

Capítulo VI inédito de O Capital. São Paulo: Editora Moraes, 1969.

O Capital - vol III, tomo 2. São Paulo: Abril Cultural, 1985.

Salário, preço e lucro. São Paulo: Abril Cultural, 1974.

Miséria da filosofia. São Paulo: Grijalbo, 1976.

MARX e ENGELS. A ideologia alemã. Portugal e Brasil: Editorial Presença e Livraria Martins Fontes, s.d.

MEYER, Regina Prósteri. Luz: um pólo metropolitano. São Paulo. In Revista PI NI, outubro de 1999.

MÔNACO, Roberto. A apropriação das terras devolutas municipais e a formação espacial da cidade de São Paulo, a partir de 1930. São Paulo, 2004. Tese de doutorado, FAUUSP.

MORAES, Antônio.C.R.; COSTA, Wanderley. M. da. A valorização do espaço. São Paulo: Hucitec, 1999.

MORSE, Richard. Formação histórica de São Paulo: São Paulo, corpo e alma do Brasil. São Paulo: Difusão Européia do Livro, 1970.

MOTA, Carlos Guilherme. I deologia da cultura brasileira. São Paulo: Editora Ática, 1977.

NERY Jr, José Marinho. Um século de política para poucos - O zoneamento paulistano 1886 - 1986. São Paulo, 2002. Tese de doutorado, FAUUSP.

NOBRE, Eduardo. Reestruturação econômica e território: expansão recente do terciário na Marginal do rio Pinheiros. São Paulo, 2000. Tese de doutorado, FAUUSP. 
OLIVEIRA, Francisco. A economia brasileira: crítica à razão dualista. In Estudos Cebrap 2. São Paulo: Ed.Brasileira de Ciência/Cebrap, 1976.

O estado e o urbano no Brasil. São Paulo: E\&D, no. 6, 1972.

Crítica à razão dualista. São Paulo: Boitempo Editorial, 2003.

OSEKI, Jorge Hajime. O único e o homogêneo na produção do espaço. In Henri Lefèbvre e o Retorno à Dialética. São Paulo: Editora Hucitec, 1996.

OSELLO, M. A. Planejamento urbano em São Paulo: 1899-1961. São Paulo: Projeto 87, 1980.

PACCA, P. E. A reprodução do espaço na periferia da metrópole e a lógica da propriedade privada. São Paulo, 2004. Dissertação de Mestrado, Departamento de Geografia, FFLCH/USP.

PEREIRA, José Matias. Estagnação econômica, governabilidade e democracia no Brasil. In Revista Espaço Acadêmico, n 35, Brasília, abril de 2004.

POCHMANN, Marcio e outros (orgs.). Proprietários - concentração e continuidade. São Paulo: Cortez Editora, 2009.

PRADO Jr, Caio. História Econômica do Brasil. São Paulo: Editora Brasiliense, 1973.

A cidade de São Paulo. In Evolução Política do Brasil e outros estudos. São Paulo: Editora Brasiliense, 1977.

. Formação do Brasi contemporâneo. São Paulo: Editora Brasiliense, 1979.

REIS FILHO, Nestor Goulart. Evolução urbana no Brasil. São Paulo: Livraria Pioneira Editora / EDUSP, 1968.

_-_São Paulo e outras cidades. São Paulo: Hucitec, 1994.

RIBEIRO, Darcy. O processo civilizatório. São Paulo: Publifolha, 2000.

RIBEIRO, Luis César de Queiroz. Dos cortiços aos condomínios fechados. Rio de Janeiro: Editora Civilização Brasileira, 1996.

ROLNIK, Raquel. A cidade e a lei. São Paulo: Livros Studio Nobel Ltda, 1997.

SAMPAIO J r, Plínio de A. Entre a nação e a barbárie. Petrópolis, RJ : Editora Vozes, 1999.

SANDRONI, Paulo. Novíssimo dicionário de economia. São Paulo: Editora Bestseller, 2001.

SANTOS, Milton. O espaço do cidadão. São Paulo: Nobel, 1987.

Metrópole corporativa fragmentada. São Paulo: Secretaria de Estado da Cultura / Nobel, 1990.

A urbanização brasileira. São Paulo: Hucitec, 1993.

A natureza do espaço - técnica e tempo, razão e emoção. São

Paulo: Editora Hucitec, 1999.

SÃO PAULO (cidade). Município em mapas. São Paulo: PMSP, SEMPLA, DIPRO, 2006. 
SECCHI, Bernardo. Primeira lição de urbanismo. São Paulo: Perspectiva, 2006.

SCHORSKE, Carle. Pensando com a história. São Paulo: Cia das Letras, 2000.

SCHWARZ, Roberto. Um mestre na periferia do capitalismo. São Paulo: Editora $34,2000$.

SEABRA, Odette. Os meandros dos rios nos meandros do poder. Tietê e Pinheiros: valorização dos rios e das várzeas na cidade de São Paulo. Tese de doutorado, FFLCH-USP, São Paulo, 1987.

. Urbanização e fragmentação. São Paulo, 2003. Tese de livredocência do departamento de Geografia. Área de conhecimento: Geografia Urbana. FFLCH/ USP.

- São Paulo: a cidade, os bairros e a periferia. In Geografia de São

Paulo: Representação e crise da Metrópole. São Paulo: Editora Contexto, 2004.

SEHAB. Secretaria da Habitação e Desenvolvimento Urbano, PMSP. Plano Municipal de Habitação (versão para debate). São Paulo, 2004.

SILVA, F. A., ALMEIDA, J. L. e FERREIRA, L. Avaliação e setorização para requalificação urbana de áreas industriais “decadentes”. São Paulo, 2006. I Seminário do Programa de Pós-Graduação Stricto Sensu em Arquitetura e Urbanismo, são Paulo.

SILVA, Luis Octávio. A reabilitação do centro de São Paulo: aspectos estratégicos, territoriais e políticos. São Paulo, 2004. Seminário: Projetos Urbanos Contemporâneos no Brasil, São Paulo.

SINGER, Paul. Desenvolvimento econômico e evolução urbana em São Paulo. São Paulo: Companhia Editora Nacional, 1974.

. Economia política da urbanização. São Paulo: Brasiliense, 1987.

Globalização e desemprego. São Paulo: Editora Contexto, 2000.

SCHIFFER (org.). Globalização e estrutura urbana. São Paulo: Hucitec, 2004.

SMITH, Neil. Gentrificação, a fronteira e a reestruturação do espaço urbano. In Espaço e Tempo, $n^{\circ} 21$, pp. 15 -31. São Paulo: GEOUSP, 2007.

SMITH, Roberto. Propriedade da terra \& transição. São Paulo: Editora Brasiliense, 1990.

SOJA, Edward W. Algunas consideraciones sobre el concepto de ciudadesregión globales. Cadernos IPPUR, ano XX, $n^{\circ} 2,2006$.

TORRES, Maria Celestina T. M. História dos bairros de São Paulo - Brás. São Paulo: Secretaria de Educação e Cultura do Município de São Paulo, 1985.

VAINER, Carlos. Os liberais fazem planejamento urbano? In: Arantes, O. Maricato, E. Vainer, C. O pensamento único das cidades: desmanchando consensos. Petrópolis, RJ: Vozes, 2000.

VÉRAS, Maura. O bairro do Brás em SP: um século de transformação do espaço urbano ou diferentes versões da segregação social. São Paulo, 1991. Tese de doutorado, PUC-SP. 
VILLAÇA, Flávio. A estrutura territorial da metrópole sul brasileira: áreas residenciais e comerciais. São Paulo, 1978. Tese de doutorado, FFLCH, Departamento de Geografia, USP, São Paulo.

VILLAÇA, Flávio. A terra como capital (ou a terra localização). In Revista Espaço \& Debates, ANO V, no. 16, São Paulo, 1985.

. O que todo cidadão precisa saber sobre habitação - São Paulo:

Global, 1986.

. Sistematização crítica da obra sobre espaço urbano. São Paulo,

1989. Tese de Livre-Docência, FAU/USP.

. Espaço intra-urbano no Brasil. São Paulo: Nobel, 1998.

WILDERODE, Daniel. Cidade à venda: interpretação do processo imobiliário. São Paulo. Tese de doutorado, FAUUSP.

Internet:

ANDRADE, José Dantas. Os primeiros desbravadores e a fundação da localidade de Tabocas. 2004. Disponível em: www.Itabuna-ba.com.br. Acesso em 17 nov. 2008

Fustigante. As muralhas. 2008. Disponível em: www. fustigante. blogspot.com. Acesso em 17 nov. 2008

Ogawa, Carlos. Ponte Grande, Ponte Pequena. 2007. Disponível em: http://blog.acessasp.sp.gov.br. Acesso em 17 nov. 2008

Pádua, Hélcias Bernardo de. O nosso Cacique Caiubi. (9/4/2008). Disponível em: http://www. saopaulominhacidade.com.br.. Acesso em 17 nov. 2008

Villaça, Flávio A produção e o uso da imagem do centro da cidade - o caso de São Paulo. (1993). Disponível em: www.flaviovillaca.arq.br. Acesso em 2007 e 2008

. Princípios para a redação de uma dissertação ou tese. (2003).

Disponível em: www. flaviovillaca.arq.br. Acesso em 2006

- Plano de pesquisa para uma tese. (2005). Disponível em www.flaviovillaca.arq.br. Acesso em 2006

www.flaviovillaca.arq.br. Acesso em 2006 e 2007

SCHWARTZMAN, Simon Subdesenvolvimento, revolução e ideologia. (1967).

Disponível em: www.schwartzman.org.br. Acesso em outubro de 2007

www.oribatejo.pt/2006 Acesso em novembro de 2007

www.evora.pt/2004 Acesso em novembro de 2007

http://www. monthlyreview.org/1004pms1.htm Acesso em outubro de 2007 
Jornais:

FOLHA DE SÃo PAULO. São Paulo: 20,19,16 e 12 /03/2009; 13/08/2008; 24/07/2008; 27/02/2007; 20/02/2007; 14/07/2004.

O ESTAdo De SÃo PAUlo. São Paulo: 19,18,14,11,09,07,05,04 e 03/03/09; 12/12/2008;15/08/08; 07/07/2008; 20/02/2008; 01/01/2007; 13/12/2002 e 02/07/2002

\section{Revistas:}

Como sair da estagnação. Retrato do Brasil. Ano IV, no. 48, setembro, 2003.

REVI STA ESPAÇO E DEBATES. São Paulo: nos. 16, 34, 37, 38, 39, 43/44, 45 e 46. Neru (Núcleo de Estudos Regionais e Urbanos), São Paulo.

REVI STA PI NI, outubro de 1999.

SWEEZY, Paul M. Por que a estagnação. Montly Review, junho de 1982.

\section{Leis:}

BRASIL. Lei $n^{\circ}$ 11.445. Política Federal para o Saneamento Básico, 2007.

BRASIL. PL $n^{\circ}$ 3057. SUBSTITUTIVO que dispõe sobre o parcelamento do solo para fins urbanos e sobre a regularização fundiária sustentável de áreas urbanas, e dá outras providências, 2007. 
Anexo 1

Lista de proprietários por nacionalidade 


\begin{tabular}{|c|c|c|}
\hline PROPRI ETÁRI OS & $\begin{array}{c}\text { Quantidade de imóveis } \\
\text { por proprietários }\end{array}$ & TOTAL \\
\hline ABD ALI ABOU HAMZE & 6 & 6 \\
\hline ABDUL KARIN HADDAD & 2 & 2 \\
\hline ABRAHÃO FELIX EHAR & 4 & 4 \\
\hline ADEMAR LACERDA ARAUJ O & 2 & 2 \\
\hline ADEMAR TREMOSECHI CURCI & 3 & 3 \\
\hline ADMIR DOS SANTOS & 2 & 2 \\
\hline ADUARIO J OSÉ DE FIGUEIREDO & 2 & 2 \\
\hline AHMAD NAZIH AREF ABDUL LATIF & 2 & 2 \\
\hline AIDE SILVA DOS SANTOS & 3 & 3 \\
\hline AJSYR GORSKY & 2 & 2 \\
\hline ALBERTO AUGUSTO VICENTE & 3 & 3 \\
\hline ALBERTO GOMES VALENTE & 2 & 2 \\
\hline ALCIDES ANGELO BELLINI & 3 & 3 \\
\hline ALEXANDRE ROGGERO & 14 & 14 \\
\hline ALFREDO DE VITA & 4 & 4 \\
\hline ALFREDO MARCHETTI & 2 & 2 \\
\hline ALFREDO TEIXEIRA & 14 & 14 \\
\hline ALI HASSAN GHARIB & 2 & 2 \\
\hline ALICE CARDOSO FLORINDO DOS SANTOS & 2 & 2 \\
\hline ALICE GONÇALVES DE ALMEIDA & 2 & 2 \\
\hline ALZIRA DAS GRACAS DE CASTRO SILVA & 8 & 8 \\
\hline ALZIRA NUNES DOS ANJ OS & 2 & 2 \\
\hline AMADOR ARAUJ O FRANCO & 2 & 2 \\
\hline AMANDIO DA RESSUREICAO PARDAL & 9 & 9 \\
\hline AMANDIO DO NASCIMENTO RODRIGUES & 2 & 2 \\
\hline AMÉLI A PROENÇA DE CASTRO ALVES & 4 & 4 \\
\hline AMERICO DO NASCIMENTO & 2 & 2 \\
\hline AMERICO MARTINELLI & 2 & 2 \\
\hline AMERICO PEREIRA DE FRIAS & 3 & 3 \\
\hline ANA FLAVIA DI SESSA MARTINS & 2 & 2 \\
\hline ANA MARIA CORDELLI MARINO & 4 & 4 \\
\hline ANA MARIA EVARISTO & 5 & 5 \\
\hline ANA PAIANO PELEGRINO & 3 & 3 \\
\hline ANDRE BRABO MARTINEZ & 2 & 2 \\
\hline ANGELA MARIA LEMOS FERRAZ & 3 & 3 \\
\hline ANGELINO CARBONE & 2 & 2 \\
\hline ANGELO CODICASA & 2 & 2 \\
\hline ANIBAL AUGUSTO DE CASTRO & 3 & 3 \\
\hline ANIBAL AUGUSTO FERREI RA & $4+2=6$ & 6 \\
\hline ANI BAL GASPAR & 7 & 7 \\
\hline ANNE STEI NWURZ & 5 & 5 \\
\hline ANTONI MANOEL ROMA FERNANDES & 2 & 2 \\
\hline ANTONI NA PORTELA TALARICO & 2 & 2 \\
\hline
\end{tabular}




\begin{tabular}{|c|c|c|}
\hline ANTONIO AMANDIO FREIRE & 2 & 2 \\
\hline ANTONIO AUGUSTO DE OLIVEIRA & 6 & 6 \\
\hline ANTONIO AUGUSTO FERNANDES & 2 & 2 \\
\hline ANTONIO AUGUSTO LOPES & 6 & 6 \\
\hline ANTONIO BONANSEA & 7 & 7 \\
\hline ANTONIO CARLOS LEONETTE & 3 & 3 \\
\hline ANTONIO COELHO FERREIRA & 2 & 2 \\
\hline ANTONIO CRISPIM DE SOUZA & 2 & 2 \\
\hline ANTONIO DAVID FREIRE REIS & $2+2=4$ & 4 \\
\hline ANTONIO DE SOUZA & 4 & 4 \\
\hline ANTONIO DOMINGOS AZEVEDO & 2 & 2 \\
\hline ANTONIO DOS SANTOS MATEUS & 5 & 5 \\
\hline ANTONIO FERRARI & 2 & 2 \\
\hline ANTONIO FERREI RA DAS NEVES & 3 & 3 \\
\hline ANTONIO FERREIRA FREITAS & 2 & 2 \\
\hline ANTONIO FERRO FI LHO & $7+18=25$ & 25 \\
\hline ANTONIO J OAO PRETO & 6 & 6 \\
\hline ANTONIO JULIO GONCALVES & $2+5=7$ & 7 \\
\hline ANTONIO LUCENA & 3 & 3 \\
\hline ANTONIO LUIZ SANDRIN & 2 & 2 \\
\hline ANTONIO MANOEL LOPES & $2+4=6$ & 6 \\
\hline ANTONIO MARIA FAILDE & 4 & 4 \\
\hline ANTONIO MARIA MARTORIELO & 3 & 3 \\
\hline ANTONIO MI GUEL & 2 & 2 \\
\hline ANTONIO MONTEIRO & 3 & 3 \\
\hline ANTONIO NASCIMENTO FLORES & 2 & 2 \\
\hline ANTONIO NASRA & 2 & 2 \\
\hline ANTONIO PASQUINI & 5 & 5 \\
\hline ANTONIO PINTO AUGUSTO & 2 & 2 \\
\hline ANTONIO PINTO TEIXEIRA & 3 & 3 \\
\hline ANTONIO SINGH & 2 & 2 \\
\hline ANTONIO SOBRAL & 3 & 3 \\
\hline EDUARDO AUGUSTO MARTINS & 7 & 7 \\
\hline EFIM COGAN & 3 & 3 \\
\hline ELEONORA WANDA NARDI & 2 & 2 \\
\hline ELIANA APARECIDA ORTIZ DE ARAUJO & 2 & 2 \\
\hline ELIDIO DE SOUSA & 4 & 4 \\
\hline ELISA AMELIA LOPES MARTINS & 7 & 7 \\
\hline ELISA HAYDÉE PEIXOTO LOPES & 3 & 3 \\
\hline ELISA RODRI GUES CANDESO & 2 & 2 \\
\hline ELVIRA DE SOUZA & 3 & 3 \\
\hline ELVIRA DOMINGUES & 2 & 2 \\
\hline ELZA VI LANOVA & 4 & 4 \\
\hline EMI LIA DE SOUZA MIGUEL E SANTOS & $5+2=7$ & 7 \\
\hline EMI LIO BARASSAL & 3 & 3 \\
\hline ESMERALDA GOMES DA SILVA BRANDAO & 4 & 4 \\
\hline
\end{tabular}




\begin{tabular}{|c|c|c|}
\hline ESP AGOSTINHO NUNES & 4 & 4 \\
\hline ESP PAUL PAUL BAMBIOLAKIS & 4 & 4 \\
\hline ESPOLIO DE DOLORATA P AVINO & 2 & 2 \\
\hline ETTORE SALERNO & 3 & 3 \\
\hline EUGENIA VAUTIER FRANCO & 7 & 7 \\
\hline EUGENIO DUARTE & $2+6=8$ & 8 \\
\hline EVANI LDO CRUZ LUZ & 3 & 3 \\
\hline FAICAL ALI ABOU EL ZEENI & 3 & 3 \\
\hline FAISAL JUNES & 2 & 2 \\
\hline FAMI LI A FERRO & 18 & 18 \\
\hline FELIPE GONCALVES DOS SANTOS & 2 & 2 \\
\hline FELIPPO MANCUSO FILHO & 2 & 2 \\
\hline FERNANDO SOARES FERRAZ & $3+$ & 3 \\
\hline FERNANDO VANNUCCI & 3 & 2 \\
\hline FLAVIA APARECIDA DA SILVA SANTOS & $2+3=5$ & 5 \\
\hline FLAVIA HANI AYACHE & 2 & 2 \\
\hline FLORINDA AMOROSO PUGLIESE & 3 & 3 \\
\hline FRANCISCO ADELINO LOPES & 2 & 2 \\
\hline FRANCISCO ANDRADE & 5 & 5 \\
\hline FRANCISCO ANTONIO FRAGATA & 5 & 5 \\
\hline FRANCISCO ANTONIO PARDAL & 3 & 3 \\
\hline FRANCISCO BRANCO & 2 & 2 \\
\hline FRANCISCO DENIG & 3 & 3 \\
\hline FRANCISCO GI L CLAUDIO & 3 & 3 \\
\hline FRANCISCO JOSE CORDEIRO & 3 & 3 \\
\hline FRANCISCO PEREIRA NETO & 11 & 11 \\
\hline FRANCISCO TEODORIO J ALES & 4 & 4 \\
\hline FRANCISCO VALENTE & 5 & 5 \\
\hline GABRIEL LUCCHESI NETTO & 2 & 2 \\
\hline GABRIEL PEREIRA & 4 & 4 \\
\hline GUALDINO FERNANDES FRANCA & 2 & 2 \\
\hline GUIDO REGGIANI & $5+2=7$ & 7 \\
\hline GUSTAVO SEMERDJIAN DESGUALDO & 5 & 5 \\
\hline HADJI SEMERDJIAN & 3 & 3 \\
\hline HAMILTON ALMEIDA LOPES & 2 & 2 \\
\hline HANI NAAIM AYACHE & $11+6+23=40$ & 40 \\
\hline HELCIO LUIZ APOSTOLICO & 4 & 4 \\
\hline HENRI QUE J OSE BABBI NI & $2+3=5$ & 5 \\
\hline HENRI QUE PICCA & $3+2=5$ & 5 \\
\hline Her Yu Cheng & 7 & 7 \\
\hline HERMINIA LOPES GONCALVES DOS REIS & 2 & 2 \\
\hline HERMINIO J OSE TEIXEI RA & 13 & 13 \\
\hline HIDEHIKO KAZIYAMA & 2 & 2 \\
\hline HILDA BERCHIELLI NUNES & 2 & 2 \\
\hline HOANES KOUTOUDJIAN & 2 & 2 \\
\hline HORACIA PAIANO MOBRIGE & 2 & 2 \\
\hline
\end{tabular}




\begin{tabular}{|c|c|c|}
\hline HORACIO ELVAS & 2 & 2 \\
\hline Hou Efun Chang & 4 & 4 \\
\hline HOUDA IBRAHIM & 10 & 10 \\
\hline Huang Cheng Wu & 2 & 2 \\
\hline HUGO MEIER & 3 & 3 \\
\hline HUMBERTO IPPOLITO & 2 & 2 \\
\hline IDA ROSENTHAL & 3 & 3 \\
\hline IGNEZ LAVIERI IZAIAS & 8 & 8 \\
\hline IGNEZ PEREIRA & 7 & 4 \\
\hline ILIDIO DELFIM FURRIEL & 3 & 3 \\
\hline I LIO VANUCCI & 3 & 3 \\
\hline INES MONACO & $12+22=34$ & 34 \\
\hline INOCÊNCIO J OAQUIM LOPES & 2 & 2 \\
\hline I OLANDA CAVALI NI FERREI RA COSTA & 1 & 1 \\
\hline IONEZ CRISTOFARO CUNHA & $7+4=11$ & 11 \\
\hline IRACEMA FURRIEL CAMPOS & 3 & 3 \\
\hline LAURI NDA DA CRUZ GUIMARO & $3+6+10=19$ & 19 \\
\hline Leiko Sunao Del Bel & 2 & 2 \\
\hline LEI LA GAZEL ABDUL GHANI & 2 & 2 \\
\hline LEONOR PESSOA DA CUNHA FERNANDES & 5 & 5 \\
\hline LEOPOLDO NOGUEI RA & 2 & 2 \\
\hline LI DIA MI GLIACI I NSERRA & 5 & 5 \\
\hline LI LY CHEDID MADI & 2 & 2 \\
\hline LUCIANO SI QUEIRA OTONI & 2 & 2 \\
\hline LUCY TEREZINHA BANACHI & 6 & 6 \\
\hline LUIGI COLOMBO & 2 & 2 \\
\hline LUIS GOMES nogueira & 2 & 2 \\
\hline LUIS GOMES TEIXEIRA & 7 & 2 \\
\hline LUIZ ANTONIO BRUZADIN & 2 & 2 \\
\hline LUIZ ANTONIO MANOEL DA CUNHA & 3 & 3 \\
\hline LUIZ AUGUSTO VICENTE & 4 & 4 \\
\hline LUIZ CARLOS NAVARRO & 4 & 4 \\
\hline LUIZ CARLOS SMOKOVITZ & 3 & 3 \\
\hline LUIZ CARRARA & 4 & 4 \\
\hline LUIZ DE SOUZA SPINDOLA & 2 & 2 \\
\hline LUIZ GONZAGA MIRANDA & 3 & 3 \\
\hline LUIZ J OAO MELLONE & 6 & 6 \\
\hline LUIZ QUISPE GUTIERREZ & 2 & 2 \\
\hline LUIZ UGOLI NI & $9+8+12=29$ & 29 \\
\hline MAFALDA SILVESTRI FIGUEIREDO & 1 & 1 \\
\hline MANOEL DE ALMEIDA & 3 & 3 \\
\hline MANOEL ALFREDO FAILDE & 7 & 7 \\
\hline MANOEL ARUJO PINTO & 3 & 3 \\
\hline MANOEL FERNANDES & 2 & 2 \\
\hline MANOEL FRANCISCO DE PAULA & 2 & 2 \\
\hline MANOEL GONCALVES FERREIRA & 8 & 8 \\
\hline
\end{tabular}




\begin{tabular}{|c|c|c|}
\hline MANOEL PEREIRA DE ALBUQUERQUE & 3 & 3 \\
\hline MANOEL RODRIGUES PINTO & 5 & 5 \\
\hline MANOEL SHAPAZIAN JUNIOR & 3 & 3 \\
\hline MANUEL ANTONIO TEIXEIRA & 21 & 21 \\
\hline MANUEL ANTONIO VICENTE & $2+1=3$ & 3 \\
\hline MANUEL DE ANDRADE NOGUEIRA & 2 & 2 \\
\hline MARCELINO FRANCISCO ZANIN & 2 & 2 \\
\hline MARCELINO SIMOES DA CONCEICAO & 5 & 5 \\
\hline MARCO ANTONIO ALBHY & 2 & 2 \\
\hline MARCOS TADDEO & 2 & 2 \\
\hline MARGARIDA TAVARES ALVES & 2 & 2 \\
\hline MARIA APARECIDA SOARES DE OLIVEI RA FRED & 3 & 3 \\
\hline MARIA APARECIDO FERSON ROCHO & 2 & 2 \\
\hline MARIA DE LOURDES BONANSEA SANA & 3 & 3 \\
\hline MARIA DE LOURDES CIPRIANO & $2+2=4$ & 4 \\
\hline MARIA HELENA REGO FREITAS UCHOA FAGUNDE & 4 & 4 \\
\hline MARI A I NEZ ULMI NI VALLE DANINO & 2 & 2 \\
\hline MARIA PALUMBO & 3 & 3 \\
\hline MARIA REIS DE MELLO & 7 & 7 \\
\hline MARIA RUA ALVES DE PAULA & 3 & 3 \\
\hline MARIA STELA GONCALVES & 3 & 3 \\
\hline MARIA THEREZA FERNANDEZ & $2+9=11$ & 11 \\
\hline MARI LIZA RODRI GUES CHI QUIZOLA & 2 & 2 \\
\hline MARINA MIKHAEL MARIA & 3 & 3 \\
\hline MARIO AMIN ABICALAN & 3 & 3 \\
\hline MARIO GABRIELLI & 1 & 1 \\
\hline MARIO MARCHINI & 2 & 2 \\
\hline MARIO MELLO & 5 & 5 \\
\hline MARIO PAPPALARDO & 3 & 3 \\
\hline MARIO SERGIO FERRO & 5 & 5 \\
\hline MARIZA NAIN ELAUR & 2 & 2 \\
\hline MARTI PEREZ & 2 & 2 \\
\hline MATI LDE EUGENIA NOGUEIRA & 2 & 2 \\
\hline MATILDE SAHD AFONSO & 2 & 2 \\
\hline MAURO CASTRO & 3 & 3 \\
\hline MAX ALFREDO BAUMERT & 2 & 2 \\
\hline MERCEDES AUGUSTA ANAYA & 2 & 2 \\
\hline MESSIAS PALHARES & 3 & 3 \\
\hline MIGUEL LUNA VEGA & 4 & 4 \\
\hline MIGUEL ZURIK & 3 & 3 \\
\hline MIRNA MOHANAD EL MUSTAPHA & 5 & 5 \\
\hline MISSAK KAHVEJIAN & 7 & 7 \\
\hline MITUMASA IKARI MOTO & $5+2$ & 7 \\
\hline MOACYR GERALDO GABRIELLI & 4 & 4 \\
\hline MOHAMAD ASSI & 2 & 2 \\
\hline MOYSES CUTIN & 3 & 3 \\
\hline
\end{tabular}




\begin{tabular}{|l|c|c|}
\hline WALDECY ALVES DE PAULA & $3+2=5$ & 5 \\
\hline WALDEMAR BAPTISTA DA CONCEICAO & 2 & 2 \\
\hline WALDEMAR SANTOS & 3 & 3 \\
\hline WALDEMIR TUAO & 3 & 3 \\
\hline WALDIR GONÇALVES & 3 & 3 \\
\hline WALKIRIA DE FATIMA FERREIRA & 10 & 10 \\
\hline WALTER DA VEI GA FERRO & 9 & 9 \\
\hline WALTER DE MORAES FONTES & 2 & 2 \\
\hline WANG DIAN XING & 6 & 6 \\
\hline WERNER ISRAEL UNGER & 3 & 3 \\
\hline WI LSON AMADIO & 7 & 7 \\
\hline WILSON ESTEVES & 2 & 2 \\
\hline WILSON EUGENIO & 3 & 3 \\
\hline WILSON JACOB & 2 & 2 \\
\hline WILSON MEI RELLES DO NASCIMENTO & 2 & 2 \\
\hline CoreanOS + 2 (33) & 84 & 84 \\
\hline SUBTOTAL & & 2040 \\
\hline Quantidade de proprietários & & 505 \\
\hline
\end{tabular}


Anexo 2

Lista de valores venais por frente de quadras

1953

1966

1978

1980

1988

1990

1995

2000

2006 


\section{Valores Venais a preços de Jul/06 \\ Deflator: IGP-DI}

\begin{tabular}{|c|c|c|c|c|c|c|c|c|c|c|}
\hline id & sq denominação & vv 1953 & vv 1966 & vv 1978 & vv 1980 & vv 1988 & vv 1990 & vv 1991 & vv 2000 & vv 2002 \\
\hline 1 & 017003azurita & 78,05 & 49,23 & 115,96 & 110,69 & 154,60 & 478,95 & 440,46 & 214,83 & 251,79 \\
\hline 2 & 017003pascoal ranie & 78,05 & 49,23 & 139,60 & 133,44 & 160,47 & 495,30 & 440,46 & 215,08 & 251,79 \\
\hline 3 & 017003ponta cruz & 78,05 & 49,23 & 115,96 & 110,69 & 154,60 & 478,95 & 440,46 & 195,27 & 229,33 \\
\hline 4 & 017004 araguaia & 78,05 & 78,77 & 115,96 & 110,69 & 154,60 & 478,95 & 440,46 & 195,27 & 251,79 \\
\hline 5 & 017004 j feliciano & 78,05 & 29,54 & 115,96 & 110,69 & 154,60 & 465,86 & 500,27 & 244,54 & 286,64 \\
\hline 6 & 017004azurita & 78,05 & 59,08 & 115,96 & 110,69 & 154,60 & 478,95 & 440,46 & 214,83 & 251,79 \\
\hline 7 & 017004pascoal ranie & 78,05 & 78,77 & 115,96 & 133,44 & 160,47 & 495,30 & 440,46 & 215,08 & 251,79 \\
\hline 8 & 017006antonio a & 78,05 & 98,46 & 115,96 & 110,69 & 154,60 & 466,51 & 413,44 & 201,74 & 236,46 \\
\hline 9 & 017006araguaia & 78,05 & 98,46 & 115,96 & 110,69 & 154,60 & 478,95 & 485,91 & 237,05 & 277,86 \\
\hline 10 & 017006felisberto & 78,05 & 98,46 & 115,96 & 110,69 & 91,00 & 326,49 & 228,24 & 96,61 & 113,22 \\
\hline 11 & 017006rio vermelho & 78,05 & 98,46 & 115,96 & 110,69 & 154,60 & 423,33 & 253,44 & 107,40 & 125,87 \\
\hline 12 & 017007antonio a & 78,05 & 98,46 & 115,96 & 110,69 & 154,60 & 466,51 & 359,45 & 196,95 & 230,85 \\
\hline 13 & 017007castelo & 72,85 & 98,46 & 327,05 & 312,86 & 208,41 & 627,47 & 440,52 & 214,83 & 251,79 \\
\hline 14 & 017007diogo & 72,85 & 49,23 & 262,32 & 89,12 & 40,33 & 222,46 & 23,61 & 94,78 & 111,09 \\
\hline 15 & 017007felisberto & 78,05 & 78,77 & 115,96 & 110,69 & 69,47 & 249,29 & 223,61 & 94,78 & 111,09 \\
\hline 16 & 017007iturama & 78,05 & 78,77 & 115,96 & 110,69 & 69,47 & 208,07 & 288,54 & 196,17 & 229,94 \\
\hline 17 & 017007nsra oliveira & 78,05 & 98,46 & & & & & & 0,00 & \\
\hline 18 & 017007pedro q mari & 72,85 & 49,23 & & 312,86 & 45,34 & 222,46 & 225,55 & 94,78 & 111,09 \\
\hline 19 & 017007pedro turvo & 72,85 & 49,23 & 93,44 & 89,12 & 62,62 & 627,47 & 440,52 & 94,78 & 251,79 \\
\hline 20 & 017007rio vermelho & 72,85 & 68,92 & 115,96 & 110,69 & 154,60 & 423,33 & 75,37 & 116,75 & 136,84 \\
\hline 21 & 017008iturama & 78,05 & 78,77 & 115,96 & 110,69 & 69,47 & 208,07 & 288,54 & 196,17 & 229,94 \\
\hline 22 & 017008miguel paulo & 78,05 & 98,46 & 233,61 & 223,27 & 184,39 & 560,73 & 440,52 & & 251,79 \\
\hline 23 & 017008nsra oliveira & 78,05 & 98,46 & 233,61 & 223,27 & 836,69 & 560,73 & 522,69 & 236,53 & 299,76 \\
\hline 24 & 017008xambivas & 78,05 & 98,46 & 233,61 & 223,27 & 98,28 & 354,63 & 231,18 & 98,05 & 114,91 \\
\hline 25 & 017010araguaia & 78,05 & 98,46 & 115,96 & 110,69 & 154,60 & 478,95 & 440,46 & 214,83 & 251,79 \\
\hline 26 & 017010com nestor $p$ & 78,05 & 59,08 & 115,96 & 110,69 & 154,60 & 478,95 & 40,46 & 226,06 & 264,97 \\
\hline 27 & 017010 & 78,05 & 59,08 & 115,96 & 110,69 & 154,60 & 478,95 & 40,46 & 214,83 & 251,79 \\
\hline 28 & 017010m maxi & 78,05 & 49,23 & 115,96 & 223,27 & 154,60 & 518,86 & 440,46 & 94,78 & 251,79 \\
\hline 29 & 017010m piscina & 78,05 & 49,23 & 115,96 & 110,69 & 154,60 & 478,95 & 463,17 & 98,05 & 114,91 \\
\hline 30 & 017010pascoal ranie & 83,26 & 98,46 & 140,16 & 133,44 & 160,47 & 495,30 & 463,33 & 226,06 & 264,97 \\
\hline 31 & 017011iturama & 78,05 & 98,46 & 115,96 & 110,69 & 69,47 & 208,07 & 288,54 & 196,17 & 278,13 \\
\hline 32 & 017011m abreu & 52,03 & 98,46 & 233,61 & 223,27 & 168,73 & 354,63 & 247,03 & 104,82 & 122,86 \\
\hline 33 & 017011mig frnceli & 52,03 & 98,46 & 233,61 & 223,27 & 43,92 & 518,86 & 288,54 & 0,00 & 114,91 \\
\hline 34 & 017011xambivas & 52,03 & 98,46 & 233,61 & 223,27 & 98,28 & 354,63 & 31,18 & 98,05 & 114,91 \\
\hline 35 & 017012bom jardim & 52,03 & 147,69 & 351,26 & 335,85 & 158,40 & 635,98 & 561,64 & 274,22 & 321,42 \\
\hline 36 & 017012iturama & 78,05 & 98,46 & 115,96 & 110,69 & 47,73 & 208,07 & 288,54 & 196,17 & 229,94 \\
\hline 37 & 017012m abreu & 52,03 & 78,77 & 233,61 & 223,27 & 43,92 & 354,63 & 231,24 & 98,05 & 114,91 \\
\hline 38 & 017012miguel paulo & 78,05 & 98,46 & 233,61 & 223,27 & 184,39 & 560,73 & 440,52 & 98,05 & 251,79 \\
\hline 39 & 017016carlos & 93,66 & 147,69 & 351,26 & 335,85 & 241,14 & 570,55 & 573,22 & 357,50 & 419,05 \\
\hline 40 & 017016joaquim & 72,85 & 196,93 & 327,05 & 312,86 & & & 495,23 & 356,29 & 417,62 \\
\hline 41 & 017016pe taddei & 57,24 & 147,69 & 233,61 & 223,27 & & & 401,83 & 354,58 & 415,89 \\
\hline 42 & 017016rodovalho & 78,05 & 196,93 & 351,26 & 335,85 & 241,14 & 570,55 & 464,04 & 355,79 & 417,04 \\
\hline 43 & 017017castelo & 72,85 & 196,93 & 327,05 & 315,23 & 187,86 & 643,83 & 735,98 & 377,13 & 387,91 \\
\hline 44 & 017017joaquim & 72,85 & 196,93 & 327,05 & 312,86 & 187,86 & 643,83 & 656,85 & 348,17 & 358,13 \\
\hline 45 & 017017paulo andrig & 72,85 & 98,46 & 327,05 & 312,86 & 187,65 & 643,83 & 656,85 & 336,63 & 346,27 \\
\hline 46 & 017017silva telles & 72,85 & 196,93 & 327,05 & 312,86 & 187,86 & 643,83 & 656,85 & 336,63 & 346,27 \\
\hline 47 & 017018araguaia & 83,26 & 98,46 & 137,91 & 133,44 & 171,23 & 405,01 & 388,66 & 354,58 & 340,29 \\
\hline 48 & 017018olarias & 57,24 & 98,46 & 419,93 & 402,69 & 255,81 & 605,88 & 464,10 & 355,79 & 417,04 \\
\hline 49 & 017018pe vieira & 88,46 & 98,46 & 419,93 & 402,69 & 187,86 & 444,27 & 349,68 & 353,99 & 198,87 \\
\hline
\end{tabular}




\begin{tabular}{|c|c|c|c|c|c|c|c|c|c|c|}
\hline 50 & 017018xande & 182,12 & 98,46 & 93,44 & 89,12 & 143,83 & 444,27 & 246,00 & 352,80 & 413,53 \\
\hline 51 & 017020bom jardim & 78,05 & 147,69 & 351,26 & 335,85 & 241,14 & 570,55 & 495,36 & 379,78 & 445,14 \\
\hline 52 & 017020cap passos & 93,66 & 147,69 & 419,37 & 402,69 & 147,10 & 605,23 & 388,70 & 378,66 & 443,83 \\
\hline 53 & 017020guaranta & 52,03 & 147,69 & 233,61 & 223,27 & 207,87 & 491,38 & 375,82 & 378,53 & 443,69 \\
\hline 54 & 017020imbauba & 78,05 & 196,93 & 233,61 & 223,27 & 207,87 & 491,38 & 375,82 & 378,53 & 443,69 \\
\hline 55 & 017020inda & 78,05 & 196,93 & 186,89 & 178,47 & 192,21 & 454,74 & 362,65 & 378,32 & 443,44 \\
\hline 56 & 017021bom jardim & 93,66 & 196,93 & 351,26 & 335,85 & 241,14 & 570,55 & 573,22 & 380,58 & 446,09 \\
\hline 57 & 017021guaranta & 52,03 & 147,69 & 233,61 & 223,27 & 207,87 & 491,38 & 375,82 & 378,53 & 443,69 \\
\hline 58 & 017021imbauba & 52,03 & 196,93 & 233,61 & 199,57 & 207,87 & 491,38 & 375,82 & 378,53 & 443,69 \\
\hline 59 & 017021piaçaguera & 52,03 & 147,69 & 139,60 & 133,44 & 171,23 & 405,01 & 362,85 & 378,43 & 443,58 \\
\hline 60 & 017022 ilo otani & 104,07 & 196,93 & 355,20 & 447,48 & 294,52 & 696,83 & 573,29 & 380,58 & 446,09 \\
\hline 61 & 017022aguaçai & 93,66 & 147,69 & 233,61 & 223,27 & 233,85 & 422,02 & 375,85 & 378,53 & 443,69 \\
\hline 62 & 017022bom jardim & 93,66 & 196,93 & 351,26 & 335,85 & 268,10 & 634,01 & 620,04 & 363,26 & 425,80 \\
\hline 63 & 017022carlos & 104,07 & 196,93 & 467,78 & 447,48 & 378,66 & 613,73 & 851,15 & 415,55 & 469,74 \\
\hline 64 & 017022piaçaguera & 83,26 & 147,69 & 139,60 & 133,44 & 206,46 & 475,67 & 375,82 & 378,43 & 469,74 \\
\hline 65 & 017024cel emidio & 83,26 & 196,93 & 327,05 & 312,86 & 235,27 & 556,15 & 336,84 & 353,78 & 443,58 \\
\hline 66 & 017024joaquim & 72,85 & 196,93 & 327,05 & 312,86 & 235,27 & 556,15 & 448,48 & 355,56 & 416,77 \\
\hline 67 & 017024pe taddei & 52,03 & 147,69 & 233,61 & 223,27 & 153,51 & 491,38 & 336,64 & 354,58 & 414,64 \\
\hline 68 & 017024rodovalho & 78,05 & 196,93 & 385,03 & 335,85 & 241,14 & 570,55 & 375,75 & 354,41 & 415,42 \\
\hline 69 & 017025cel emidio & 83,26 & 196,93 & 327,05 & 312,86 & 235,27 & 556,15 & 510,98 & 379,93 & 445,33 \\
\hline 70 & 017025joaquim & 78,05 & 196,93 & 327,05 & 312,86 & 235,27 & 556,15 & 375,88 & 378,53 & 443,69 \\
\hline 71 & dovalho & 78,05 & 196,93 & 385,03 & 335,85 & 241,14 & 570,55 & 464,04 & 379,47 & 444,80 \\
\hline 72 & 5silva telles & 93,66 & 787,71 & 421,06 & 402,69 & 458,90 & 2196,48 & 923,10 & 571,89 & 628,06 \\
\hline 73 & 017026olarias & 52,03 & 196,93 & 233,61 & 223,27 & 207,87 & 491,38 & 362,72 & 354,20 & 415,17 \\
\hline 74 & 017026pe vieira & 88,46 & 98,46 & 163,24 & 155,72 & 187,86 & 444,27 & 323,77 & 353,41 & 414,25 \\
\hline 75 & 017026xande & 72,85 & 78,77 & 92,32 & 89,12 & 143,83 & 340,23 & 246,00 & 352,80 & 413,53 \\
\hline 76 & 017027 manuel d h & 72,85 & 98,46 & 93,44 & & & & & & 414,92 \\
\hline 77 & $\begin{array}{l}017027 \text { morro } \\
\text { grande }\end{array}$ & 72,85 & 68,92 & 93,44 & 89,12 & 143,83 & 340,23 & 310,70 & 353,99 & 413,53 \\
\hline 78 & 017027 s biaggio & 72,85 & 78,77 & 93,44 & 89,12 & 165,58 & 340,23 & 284,62 & 351,86 & 321,26 \\
\hline 79 & 017027sacramen & 72,85 & 78,77 & 93,44 & 89,12 & 143,83 & 340,23 & 310,70 & 352,80 & 413,53 \\
\hline 80 & 017027venucci & 72,85 & 68,92 & 93,44 & 89,12 & 143,83 & 340,23 & 219,69 & 326,95 & 383,23 \\
\hline 81 & 017028cachoeira & 83,26 & 787,71 & 327,05 & 312,86 & 235,27 & 556,15 & 375,88 & 378,53 & 443,69 \\
\hline 82 & 017028cap passos & 93,66 & 196,93 & 419,93 & 402,69 & 255,81 & 605,23 & 388,70 & 378,66 & 443,83 \\
\hline 83 & 017028guaranta & 52,03 & 196,93 & 233,61 & 223,27 & 207,87 & 491,38 & 375,82 & 378,53 & 443,69 \\
\hline 84 & 017028imbauba & 52,03 & 196,93 & 233,61 & 223,27 & 207,87 & 491,38 & 375,82 & 378,53 & 443,69 \\
\hline 85 & 017029cachoeira & 72,85 & 196,93 & 372,08 & 312,86 & 235,27 & 556,15 & 375,82 & 359,33 & 443,69 \\
\hline 86 & 017029carlos & 104,07 & 246,16 & 467,78 & 447,48 & 378,66 & 613,73 & 836,59 & 408,52 & 461,81 \\
\hline 87 & 017029guaranta & 52,03 & 196,93 & 233,61 & 81,06 & 207,87 & 491,38 & 375,82 & 378,53 & 443,69 \\
\hline 88 & 017029imbauba & 52,03 & 147,69 & 233,61 & 223,27 & 207,87 & 491,38 & 375,82 & 378,53 & 443,69 \\
\hline 89 & 017030aguaçai & 52,03 & 147,69 & 233,61 & 223,27 & 153,51 & 491,38 & 375,82 & 378,53 & 443,69 \\
\hline 90 & 017030ca & 104,07 & 196,93 & 467,78 & 447,48 & 378,66 & 613,73 & 836,59 & 408,52 & 461,81 \\
\hline 91 & 017030imbauba & 52,03 & 147,69 & 233,61 & 223,27 & 207,87 & 491,38 & 375,82 & 378,53 & 443,69 \\
\hline 92 & 017030piaçaguera & 83,26 & 147,69 & 138,48 & 133,44 & 171,23 & 405,01 & 362,52 & 378,43 & 443,58 \\
\hline 93 & 017031 ilo otani & 104,07 & 196,93 & 467,78 & 447,48 & 378,66 & 613,73 & 851,15 & 415,55 & 469,74 \\
\hline 94 & 017031cachoeira & 93,66 & 246,16 & 419,37 & 402,69 & 255,81 & 605,23 & 481,28 & 379,60 & 444,96 \\
\hline 95 & 017031carlos & 130,09 & 196,93 & 585,43 & 554,85 & 415,85 & 673,93 & 934,65 & 456,41 & 515,93 \\
\hline 96 & 017031dr virgilio nas & 93,66 & 196,93 & 421,06 & 402,69 & 255,81 & 605,23 & 388,70 & 378,66 & 443,83 \\
\hline 97 & 017032 ilo otani & 130,09 & 196,93 & 467,78 & 447,48 & 273,97 & 647,75 & 401,93 & 354,81 & 415,89 \\
\hline 98 & 017032cel emidio & 93,66 & 196,93 & 421,06 & 402,69 & 255,81 & 605,23 & 375,82 & 354,41 & 415,42 \\
\hline 99 & 017032dr virgilio nas & 93,66 & 196,93 & 421,06 & 402,69 & 255,81 & 605,23 & 343,53 & 353,99 & 414,92 \\
\hline 100 & 017032godoi & 72,85 & 196,93 & 383,34 & 312,86 & 235,27 & 556,15 & 336,84 & 353,78 & 414,67 \\
\hline 101 & 017032pedroso & 93,66 & 246,16 & 421,06 & 402,69 & 255,81 & 605,23 & 448,54 & 355,56 & 416,77 \\
\hline
\end{tabular}




\begin{tabular}{|c|c|c|c|c|c|c|c|c|c|c|}
\hline 102 & 017034cel emidio & 72,85 & 196,93 & 327,05 & 312,86 & 235,27 & 556,15 & 375,88 & 378,53 & 443,69 \\
\hline 103 & 017034rodovalho & 72,85 & 196,93 & 356,88 & 335,85 & 241,14 & 570,55 & 391,61 & 378,53 & 444,22 \\
\hline 104 & 017034silva telles & 93,66 & 196,93 & 419,37 & 402,69 & 458,90 & 2196,48 & 974,76 & 572,91 & 629,19 \\
\hline 105 & 017034siqueira a & 52,03 & 147,69 & 233,61 & 223,27 & 153,51 & 491,38 & 375,66 & 378,62 & 443,80 \\
\hline 106 & 017037itaqui & 78,05 & 196,93 & 351,26 & 335,85 & 241,14 & 570,55 & 323,83 & 353,43 & 414,25 \\
\hline 107 & 017037jurua & 78,05 & 196,93 & 233,61 & 223,27 & 207,87 & 491,38 & 336,71 & 353,76 & 414,64 \\
\hline 108 & 017037tiers & 83,26 & 196,93 & 374,33 & 357,89 & 248,53 & 587,56 & 479,60 & 355,03 & 416,15 \\
\hline 109 & 017038itaqui & 78,05 & 196,93 & 345,63 & 335,85 & 241,14 & 570,55 & 349,78 & 353,99 & 414,92 \\
\hline 110 & 017038jurua & 78,05 & 196,93 & 233,61 & 223,27 & 207,87 & 491,38 & 336,71 & 353,78 & 414,33 \\
\hline 111 & 017038olarias & 52,03 & 196,93 & 233,61 & 223,27 & 207,87 & 491,38 & 448,48 & 355,56 & 416,77 \\
\hline 112 & 017038paganini & 52,03 & 196,93 & 351,26 & 335,85 & 240,92 & 570,55 & 448,48 & 355,31 & 416,47 \\
\hline 113 & 017038tiers & 83,26 & 196,93 & 374,33 & 357,89 & 248,53 & 587,56 & 479,60 & 355,31 & 416,47 \\
\hline 114 & 017039itaqui & 78,05 & 196,93 & 351,26 & 335,85 & 241,14 & 570,55 & 349,78 & 353,99 & 414,92 \\
\hline 115 & 017039olarias & 52,03 & 196,93 & 233,61 & 223,27 & 207,87 & 491,38 & 336,71 & 353,57 & 414,64 \\
\hline 116 & 017039paganini & 52,03 & 196,93 & 356,88 & 335,85 & 240,92 & 570,55 & 433,02 & 355,31 & 416,47 \\
\hline 117 & 017039rio bonito & 52,03 & 196,93 & 419,37 & 402,69 & 255,81 & 605,23 & 464,10 & 355,79 & 417,04 \\
\hline 118 & 017040alan kardec & 130,09 & 98,46 & 139,60 & 133,44 & 171,23 & 405,01 & 323,80 & 353,43 & 414,25 \\
\hline 119 & 017040olarias & 208,14 & 196,93 & 139,60 & 223,50 & 207,87 & 491,38 & 495,36 & 356,29 & 417,62 \\
\hline 120 & 017040teresa m & 130,09 & 98,46 & 139,60 & 223,50 & 171,23 & 405,01 & 495,36 & 354,58 & 415,61 \\
\hline 121 & 017041alan kardec & 208,14 & 98,46 & 139,60 & 133,44 & 171,23 & 405,01 & 323,80 & 353,43 & 414,25 \\
\hline 122 & 017041morro grande & 208,14 & 98,46 & 93,44 & 89,12 & 143,83 & 340,23 & 310,70 & 353,43 & 322,19 \\
\hline 123 & 0170 & 208,14 & 196,93 & 233,61 & 223,03 & 207,87 & 491,38 & 336,71 & 353,76 & 417,78 \\
\hline 124 & 017041pe vieira & 88,46 & 196,93 & 163,24 & 155,72 & 187,86 & 444,27 & 349,52 & 353,99 & 414,92 \\
\hline 125 & 017041rio bonito & 72,85 & 196,93 & 419,37 & 402,69 & 255,81 & 605,23 & 510,63 & 356,52 & 417,90 \\
\hline 126 & 017041teresa m & 130,09 & 98,46 & 93,44 & 402,69 & 171,23 & 405,01 & 510,63 & 354,58 & 415,03 \\
\hline 127 & 017042c passos & 93,66 & 196,93 & 419,37 & 402,69 & 255,81 & 605,23 & 375,85 & 379,93 & 415,42 \\
\hline 128 & 017042cachoeira & 72,85 & 196,93 & 327,05 & 312,86 & 235,27 & 556,15 & 336,84 & 353,78 & 414,67 \\
\hline 129 & 017042manuel d h & 72,85 & 98,46 & 327,05 & 314,99 & 235,27 & 556,15 & 401,73 & 354,80 & 415,86 \\
\hline 130 & 017042rio bonito & 93,66 & 196,93 & 419,37 & 402,69 & 255,81 & 605,23 & 454,76 & 356,02 & 417,31 \\
\hline 131 & 017042sacramento & 72,85 & 98,46 & 93,44 & 89,12 & 143,83 & 340,23 & 336,77 & 353,78 & 414,67 \\
\hline 132 & 017043c passos & 93,66 & 196,93 & 417,12 & 402,69 & 255,81 & 605,23 & 408,11 & 378,66 & 443,83 \\
\hline 133 & 017043cachoeira & 72,85 & 196,93 & 327,05 & 312,86 & 235,27 & 556,15 & 463,20 & 379,47 & 444,80 \\
\hline 134 & 017043guaranta & 52,03 & 196,93 & 346,19 & 223,27 & 207,87 & 491,38 & 401,83 & 378,78 & 443,98 \\
\hline 135 & 017043rio bonito & 93,66 & 196,93 & 421,06 & 402,69 & 255,81 & 605,23 & 375,72 & 380,39 & 445,87 \\
\hline 136 & 017044cachoeira & 72,85 & 196,93 & 327,05 & 312,86 & 235,27 & 556,15 & 375,72 & 378,53 & 443,69 \\
\hline 137 & $\begin{array}{l}\text { 017044carlos } \\
\text { campos }\end{array}$ & 130,09 & 246,16 & 585,43 & 559,59 & 394,10 & 673,93 & 934,65 & 408,52 & 515,93 \\
\hline 138 & 017044guaranta & 52,03 & 196,93 & 233,61 & 223,27 & 207,87 & 491,38 & 375,82 & 378,53 & 443,69 \\
\hline 139 & 017044rio bonito & 52,03 & 196,93 & 419,37 & 402,69 & 255,81 & 605,23 & 401,86 & 378,78 & 443,98 \\
\hline 140 & 01704 & 93,66 & 246,16 & 419,37 & 312,86 & 255,81 & 605,23 & 479,67 & 379,60 & 444,96 \\
\hline 141 & $\begin{array}{l}\text { 017045carlos } \\
\text { campos }\end{array}$ & 130,09 & 246,16 & 585,43 & 559,59 & 394,10 & 673,93 & 934,65 & 408,52 & 515,93 \\
\hline 142 & 017045dr virgilio nas & 93,66 & 295,39 & 419,37 & 402,69 & 255,81 & 605,23 & 510,79 & 379,93 & 445,33 \\
\hline 143 & 017045rio bonito & 93,66 & 295,39 & 419,37 & 402,69 & 255,81 & 605,23 & 557,79 & 380,39 & 445,87 \\
\hline 144 & 017046cachoeira & 93,66 & 246,16 & 419,37 & 312,86 & 255,81 & 605,23 & 510,79 & 379,93 & 445,33 \\
\hline 145 & 017046cel emidio & 93,66 & 196,93 & 419,37 & 402,69 & 255,81 & 605,23 & 388,70 & 378,66 & 443,83 \\
\hline 146 & 017046dr virgilio nas & 93,66 & 196,93 & 419,37 & 402,69 & 255,81 & 605,23 & 417,42 & 378,99 & 444,22 \\
\hline 147 & 017046godoi & 72,85 & 196,93 & 327,05 & 312,86 & 235,27 & 556,15 & 375,88 & 378,53 & 443,69 \\
\hline 148 & 017047cachoeira & 93,66 & 246,16 & 419,37 & 312,86 & 255,81 & 605,23 & 464,10 & 379,47 & 444,80 \\
\hline 149 & 017047cel emidio & 93,66 & 196,93 & 419,37 & 402,69 & 255,81 & 605,23 & 388,70 & 378,66 & 443,83 \\
\hline 150 & 017047godoi & 72,85 & 196,93 & 327,05 & 312,86 & 235,27 & 556,15 & 495,23 & 379,78 & 445,14 \\
\hline 151 & 017047silva telles & 93,66 & 196,93 & 419,37 & 402,69 & 458,90 & 2196,48 & 975,41 & 572,91 & 629,19 \\
\hline 152 & 017048cel emidio & 93,66 & 196,93 & 419,37 & 402,69 & 255,81 & 605,23 & 388,70 & 378,66 & 443,83 \\
\hline
\end{tabular}




\begin{tabular}{|c|c|c|c|c|c|c|c|c|c|c|}
\hline 153 & 017048godoi & 72,85 & 295,39 & 327,05 & 312,86 & 235,27 & 556,15 & 375,88 & 378,53 & 425,80 \\
\hline 154 & 017048pedroso & 93,66 & 246,16 & 419,37 & 402,69 & 255,81 & 605,23 & 620,04 & 363,26 & 425,80 \\
\hline 155 & 017048silva telles & 93,66 & 196,93 & 419,37 & 402,69 & 458,90 & 2196,48 & 923,10 & 571,89 & 628,06 \\
\hline 156 & 017049cel emidio & 72,85 & 196,93 & 327,05 & 312,86 & 255,81 & 556,15 & 375,88 & 378,53 & 443,69 \\
\hline 157 & 017049pedroso & 93,66 & 246,16 & 419,37 & 402,69 & 255,81 & 605,23 & 495,55 & 379,78 & 445,14 \\
\hline 158 & 017049silva telles & 93,66 & 196,93 & 419,37 & 402,69 & 458,90 & 2196,48 & 923,10 & 566,50 & 622,13 \\
\hline 159 & 017049siqueira a & 93,66 & 246,16 & 233,61 & 223,27 & 153,51 & 491,38 & 360,94 & 378,62 & 443,80 \\
\hline 160 & 017052dantas & 78,05 & 246,16 & 351,82 & 335,85 & 241,14 & 570,55 & 433,02 & 355,31 & 416,47 \\
\hline 161 & 017052itaqui & 78,05 & 196,93 & 351,26 & 335,85 & 241,14 & 570,55 & 349,78 & 353,99 & 414,92 \\
\hline 162 & 017052tiers & 78,05 & 246,16 & 374,33 & 357,89 & 248,53 & 587,56 & 349,78 & 353,99 & 414,92 \\
\hline 163 & 017052vautier & 78,05 & 295,39 & 351,26 & 335,85 & 241,14 & 570,55 & 526,38 & 356,77 & 418,17 \\
\hline 164 & 017053dantas & 78,05 & 246,16 & 351,26 & 335,85 & 241,14 & 570,55 & 323,83 & 353,43 & 414,25 \\
\hline 165 & 017053itaqui & 78,05 & 196,93 & 351,26 & 335,85 & 241,14 & 570,55 & 323,83 & 353,43 & 414,25 \\
\hline 166 & 017053paganini & 78,05 & 196,93 & 351,26 & 335,85 & 241,14 & 570,55 & 464,04 & 355,79 & 417,04 \\
\hline 167 & 017053tiers & 78,05 & 246,16 & 374,33 & 357,89 & 248,53 & 587,56 & 464,04 & 355,79 & 417,04 \\
\hline 168 & 017054dantas & 78,05 & 246,16 & 351,26 & 335,85 & 241,14 & 570,55 & 349,78 & 353,99 & 414,92 \\
\hline 169 & 017054itaqui & 78,05 & 196,93 & 351,26 & 335,85 & 241,14 & 570,55 & 464,04 & 355,79 & 417,04 \\
\hline 170 & 017054paganini & 78,05 & 196,93 & 351,26 & 335,85 & 241,14 & 570,55 & 349,78 & 353,99 & 414,92 \\
\hline 171 & 017054rio bonito & 93,66 & 246,16 & 421,06 & 402,69 & 255,81 & 605,23 & 464,10 & 355,79 & 417,04 \\
\hline 172 & 017054rodovalho & 78,05 & 246,16 & 421,06 & 402,69 & 255,81 & 605,23 & 464,10 & 378,99 & 417,04 \\
\hline 173 & 017055cel morais & 93,66 & 295,39 & 421,06 & 402,69 & 254,73 & 605,23 & 464,10 & 379,28 & 444,80 \\
\hline 174 & 5drpacheco & 93,66 & 295,39 & 421,06 & 1161,13 & 255,81 & 605,23 & 510,79 & 379,93 & 445,33 \\
\hline 175 & 017055rio bonito & 93,66 & 246,16 & 421,06 & 402,69 & 255,81 & 570,55 & 463,13 & 379,68 & 445,03 \\
\hline 176 & 017055silva gomes & 78,05 & 196,93 & 351,26 & 335,85 & 241,14 & 605,23 & 417,49 & 379,22 & 444,50 \\
\hline 177 & 017056cap passos & 93,66 & 196,93 & 421,06 & 402,69 & 255,81 & 605,23 & 432,98 & 355,31 & 416,47 \\
\hline 178 & 017056cel morais & 93,66 & 393,85 & 421,06 & 402,69 & 255,81 & 605,23 & 417,42 & 354,45 & 416,15 \\
\hline 179 & 017056dr pacheco & 93,66 & 295,39 & 421,06 & 402,69 & 255,81 & 605,23 & 432,98 & 355,31 & 416,47 \\
\hline 180 & 017056rio bonito & 93,66 & 196,93 & 421,06 & 402,69 & 255,81 & 605,23 & 432,98 & 355,31 & 416,47 \\
\hline 181 & 017057carlos & 130,09 & 196,93 & 585,43 & 559,59 & 394,10 & 673,93 & 934,65 & 456,41 & 515,93 \\
\hline 182 & 017057cel morais & 93,66 & 295,39 & 421,06 & 402,69 & 255,81 & 605,23 & 349,81 & 353,99 & 414,92 \\
\hline 183 & 017057dr pacheco & 93,66 & 295,39 & 421,06 & 402,69 & 255,81 & 605,23 & 349,81 & 353,99 & 414,92 \\
\hline 184 & 017057pe lima & 93,66 & 295,39 & 421,06 & 165,67 & 255,81 & 605,23 & 349,81 & 353,99 & 414,92 \\
\hline 185 & 017058c passos & 93,66 & 196,93 & 421,06 & 402,69 & 255,81 & 605,23 & 510,69 & 379,93 & 445,33 \\
\hline 186 & 017058carlos & 130,09 & 295,39 & 585,43 & 559,59 & 415,85 & 673,93 & 934,65 & 456,41 & 515,93 \\
\hline 187 & 017058cel morais & 93,66 & 295,39 & 421,06 & 402,69 & 255,81 & 605,23 & 417,75 & 378,99 & 444,22 \\
\hline 188 & 017058rio bonito & 93,66 & 196,93 & 421,06 & 402,69 & 255,81 & 605,23 & 509,01 & 379,93 & 445,33 \\
\hline 189 & 017059carlos & 130,09 & 295,39 & 585,43 & 559,59 & 415,85 & 673,93 & 934,65 & 456,41 & 515,93 \\
\hline 190 & 017059dr virgilio & 93,66 & 295,39 & 421,06 & 402,69 & 255,81 & 605,23 & 510,79 & 379,93 & 445,33 \\
\hline 191 & 017059j boemer & 93,66 & 295,39 & 421,06 & 402,69 & 255,81 & 605,23 & 510,79 & 379,93 & 445,33 \\
\hline 192 & 017059rio bonito & 93,66 & 295,39 & 421,06 & 402,69 & 255,81 & 605,23 & 479,67 & 379,60 & 444,96 \\
\hline 193 & 017060cachoeira & 93,66 & 246,16 & 421,06 & 402,69 & 255,81 & 605,23 & 464,10 & 379,47 & 444,80 \\
\hline 194 & 017060cel emidio & 93,66 & 295,39 & 421,06 & 402,69 & 255,81 & 605,23 & 479,67 & 379,60 & 444,96 \\
\hline 195 & 017060dr virgilio nas & 93,66 & 295,39 & 421,06 & 402,69 & 255,81 & 605,23 & 510,79 & 378,86 & 444,22 \\
\hline 196 & 017060rio bonito & 93,66 & 295,39 & 421,06 & 402,69 & 255,81 & 605,23 & 557,79 & 380,39 & 445,87 \\
\hline 197 & 017061cachoeira & 93,66 & 246,16 & 421,06 & 402,69 & 255,81 & 605,23 & 526,35 & 380,12 & 445,87 \\
\hline 198 & 017061cel emidio & 93,66 & 295,39 & 421,06 & 402,69 & 255,81 & 605,23 & 388,70 & 378,66 & 443,83 \\
\hline 199 & 017061rio bonito & 93,66 & 196,93 & 421,06 & 402,69 & 255,81 & 605,23 & 480,09 & 379,47 & 444,80 \\
\hline 200 & 017061silva telles & 93,66 & 295,39 & 421,06 & 402,69 & 458,90 & 2196,48 & 1001,29 & 572,91 & 629,19 \\
\hline 201 & 017064camomil & 52,03 & 246,16 & 233,61 & 223,27 & 207,87 & 491,38 & 417,39 & 356,72 & 416,15 \\
\hline 202 & 017064dantas & 78,05 & 246,16 & 351,26 & 335,85 & 241,14 & 570,55 & 433,02 & 355,31 & 416,47 \\
\hline 203 & 017064tiers & 83,26 & 295,39 & 351,82 & 357,89 & 248,53 & 587,56 & 510,98 & 356,52 & 417,90 \\
\hline 204 & 017064vautier & 78,05 & 246,16 & 359,14 & 342,72 & 241,14 & 569,24 & 542,07 & 357,04 & 418,50 \\
\hline
\end{tabular}




\begin{tabular}{|c|c|c|c|c|c|c|c|c|c|c|}
\hline 205 & 017065camomil & 52,03 & 295,39 & 233,61 & 223,27 & 207,87 & 491,38 & 448,48 & 355,56 & 416,77 \\
\hline 206 & 017065hannemann & 52,03 & 295,39 & 233,61 & 223,27 & 207,87 & 491,38 & 495,36 & 356,29 & 417,62 \\
\hline 207 & 017065tiers & 83,26 & 295,39 & 374,33 & 357,89 & 248,53 & 587,56 & 479,60 & 356,02 & 417,31 \\
\hline 208 & 017065vautier & 78,05 & 295,39 & 351,26 & 335,85 & 241,14 & 570,55 & 573,22 & 357,50 & 419,05 \\
\hline 209 & 017066dantas & 78,05 & 246,16 & 351,26 & 335,85 & 246,57 & 589,52 & 405,42 & 335,67 & 457,20 \\
\hline 210 & 017066hannemann & 93,66 & 295,39 & 421,06 & 402,69 & 268,10 & 491,38 & 446,05 & 336,17 & 457,20 \\
\hline 211 & 017066rio bonito & 104,07 & 295,39 & 467,78 & 402,69 & 282,78 & 675,89 & 446,12 & 336,17 & 457,20 \\
\hline 212 & 017066tiers & 83,26 & 246,16 & 374,33 & 357,89 & 251,46 & 587,56 & 436,74 & 336,02 & 457,20 \\
\hline 213 & 017067celmorais & 93,66 & 295,39 & 419,37 & 402,69 & 255,81 & 605,23 & 388,70 & 378,66 & 443,83 \\
\hline 214 & 017067ornelas & 78,05 & 295,39 & 419,37 & 402,69 & 273,97 & 605,23 & 510,82 & 379,93 & 445,33 \\
\hline 215 & 017067rio bonito & 93,66 & 295,39 & 419,37 & 402,69 & 255,81 & 605,23 & 510,66 & 378,53 & 445,03 \\
\hline 216 & 017067silva gomes & 78,05 & 196,93 & 351,26 & 335,85 & 241,14 & 570,55 & 464,04 & 379,22 & 444,50 \\
\hline 217 & 017068cel & 78,05 & 295,39 & 419,37 & 402,69 & 255,81 & 605,23 & 388,70 & 378,66 & 443,83 \\
\hline 218 & 017068dr pacheco & 93,66 & 295,39 & 419,37 & 402,69 & 255,81 & 605,23 & 510,79 & 379,93 & 445,33 \\
\hline 219 & 017068ornelas & 104,07 & 295,39 & 524,07 & 442,74 & 273,97 & 647,75 & 510,82 & 379,93 & 445,33 \\
\hline 220 & 017068pe lima & 93,66 & 295,39 & 419,37 & 450,09 & 255,81 & 605,23 & 388,70 & 378,66 & 443,83 \\
\hline 221 & 017069dr pacheco & 104,07 & 295,39 & 421,06 & 402,69 & 255,81 & 605,23 & 510,79 & 379,93 & 445,33 \\
\hline 222 & 017069e rudge & 93,66 & 295,39 & 421,06 & 402,69 & 277,56 & 605,23 & 557,79 & 380,39 & 445,87 \\
\hline 223 & 017069ornelas & 93,66 & 295,39 & 421,06 & 449,85 & 273,97 & 647,75 & 479,76 & 378,66 & 444,69 \\
\hline 224 & 017069pe lima & 93,66 & 295,39 & 421,06 & 402,45 & 255,81 & 605,23 & 388,70 & 378,66 & 443,83 \\
\hline 225 & 017070carlos & 93,66 & 295,39 & 585,43 & 559,59 & 415,85 & 673,93 & 934,65 & 456,41 & 515,93 \\
\hline 226 & 017070dr pacheco & 93,66 & 295,39 & 421,06 & 402,69 & 255,81 & 605,23 & 375,85 & 354,41 & 415,42 \\
\hline 227 & 017070pe lima & 93,66 & 295,39 & 421,06 & 402,69 & 255,81 & 605,23 & 349,81 & 353,99 & 414,92 \\
\hline 228 & 017071carlos & 130,09 & 295,39 & 585,43 & 559,59 & 415,85 & 673,93 & 934,65 & 456,41 & 515,93 \\
\hline 229 & 017071dr virgilio nas & 93,66 & 295,39 & 421,06 & 402,69 & 255,81 & 605,23 & 934,65 & 355,79 & 417,04 \\
\hline 230 & 017071e rudge & 93,66 & 295,39 & 421,06 & 402,69 & 255,81 & 605,23 & 541,91 & 357,04 & 418,50 \\
\hline 231 & 017071mendes gon & 93,66 & 295,39 & 421,06 & 402,69 & 255,81 & 605,23 & 464,10 & 355,79 & 417,04 \\
\hline 232 & 017072cel emidio & 260,17 & 295,39 & 421,06 & 402,69 & 255,81 & 605,23 & 479,67 & 356,52 & 444,96 \\
\hline 233 & 017072dr virgilio & 93,66 & 295,39 & 421,06 & 402,69 & 255,81 & 605,23 & 479,67 & 379,47 & 444,80 \\
\hline 234 & 017072j boemer & 93,66 & 196,93 & 421,06 & 402,69 & 255,81 & 605,23 & 575,49 & 379,93 & 417,04 \\
\hline 235 & 017072rio bonito & 93,66 & 295,39 & 421,06 & 402,69 & 255,81 & 605,23 & 411,57 & 378,78 & 444,30 \\
\hline 236 & 017073cel emidio & 93,66 & 295,39 & 421,06 & 402,69 & 255,81 & 605,23 & 495,23 & 356,52 & 445,14 \\
\hline 237 & 017073j boemer & 93,66 & 295,39 & 421,06 & 402,69 & 255,81 & 605,23 & 575,49 & 379,93 & 445,33 \\
\hline 238 & 017073rio bonito & 93,66 & 295,39 & 421,06 & 402,69 & 255,81 & 605,23 & 557,79 & 380,39 & 445,87 \\
\hline 239 & 017073silva telles & 93,66 & 295,39 & 421,06 & 402,69 & 458,90 & 2196,48 & 1001,29 & 380,89 & 629,19 \\
\hline 240 & 017075alexandrino & 52,03 & 246,16 & 356,88 & 335,85 & 245,70 & 589,52 & 492,57 & 336,71 & 457,20 \\
\hline 241 & 017075hannemann & 93,66 & 295,39 & 421,06 & 223,27 & 196,13 & 469,13 & 418,20 & 379,93 & 457,20 \\
\hline 242 & 017075tiers & 93,66 & 295,39 & 351,26 & 357,89 & 251,46 & 601,30 & 418,30 & 335,82 & 457,20 \\
\hline 243 & 017075vautier & 93,66 & 295,39 & 421,06 & 400,55 & 268,10 & 641,21 & 501,76 & 335,00 & 300,45 \\
\hline 244 & 017076alexandrino & 78,05 & 246,16 & 356,88 & 335,85 & 245,70 & 641,21 & 392,90 & 334,81 & 457,20 \\
\hline 245 & 017076hannemann & 93,66 & 295,39 & 233,61 & 402,69 & 268,10 & 641,21 & 511,05 & 337,19 & 457,20 \\
\hline 246 & 017076pe bento & 93,66 & 295,39 & 421,06 & 402,69 & 246,35 & 641,21 & 418,17 & 335,82 & 457,20 \\
\hline 247 & 017076rodrigues san & 93,66 & 393,85 & 374,33 & 402,69 & 268,10 & 641,21 & 418,17 & 336,40 & 457,20 \\
\hline 248 & 017076tiers & 83,26 & 295,39 & 374,33 & 357,89 & 251,46 & 601,30 & 436,74 & 336,02 & 457,20 \\
\hline 249 & 017077cel morais & 93,66 & 295,39 & 419,37 & 402,69 & 255,81 & 605,23 & 464,10 & 379,47 & 444,80 \\
\hline 250 & 017077m marcolina & 104,07 & 295,39 & 355,20 & 449,85 & 273,97 & 647,75 & 510,82 & 379,93 & 445,33 \\
\hline 251 & 017077ornelas & 104,07 & 295,39 & 355,20 & 449,85 & 273,97 & 647,75 & 510,82 & 379,93 & 445,33 \\
\hline 252 & 017077paraiba & 83,26 & 246,16 & 355,20 & 357,89 & 241,14 & 587,56 & 510,82 & 207,11 & 445,33 \\
\hline 253 & 017077pe bento & 93,66 & 295,39 & 355,20 & 402,69 & 273,97 & 647,75 & 473,65 & 365,82 & 428,80 \\
\hline 254 & 017078cel morais & 93,66 & 295,39 & 421,06 & 402,69 & 255,81 & 605,23 & 388,70 & 378,66 & 443,83 \\
\hline 255 & 017078ornelas & 104,07 & 295,39 & 467,78 & 449,85 & 273,97 & 647,75 & 388,70 & 374,82 & 443,83 \\
\hline 256 & 017078paraiba & 83,26 & 246,16 & 374,33 & 469,29 & 246,35 & 587,56 & 510,98 & 207,11 & 445,33 \\
\hline
\end{tabular}




\begin{tabular}{|c|c|c|c|c|c|c|c|c|c|c|}
\hline 257 & 017078pe lima & 93,66 & 295,39 & 421,06 & 402,69 & 255,81 & 605,23 & 510,98 & 379,93 & 445,33 \\
\hline 258 & 017079eduardo rud & 93,66 & 295,39 & 421,06 & 402,69 & 255,81 & 605,23 & 588,91 & 357,04 & 446,27 \\
\hline 259 & 017079ornelas & 83,26 & 295,39 & 374,33 & 449,85 & 273,97 & 647,75 & 417,29 & 378,99 & 443,83 \\
\hline 260 & 017079p.lima & 93,66 & 295,39 & 419,37 & 402,69 & 255,81 & 605,23 & 388,70 & 378,66 & 443,83 \\
\hline 261 & 017079paraiba & 93,66 & 246,16 & 374,33 & 402,69 & 246,35 & 587,56 & 464,23 & 379,47 & 444,80 \\
\hline 262 & 017080cel emidio & 93,66 & 295,39 & 419,37 & 402,69 & 255,81 & 605,23 & 510,79 & 356,52 & 417,90 \\
\hline 263 & 017080dr virgilio & 93,66 & 295,39 & 419,37 & 402,69 & 255,81 & 605,23 & 510,79 & 355,79 & 417,04 \\
\hline 264 & 017080j boemer & 93,66 & 295,39 & 419,37 & 402,69 & 255,81 & 605,23 & 464,10 & 355,79 & 417,04 \\
\hline 265 & 017080mendes gon & 93,66 & 295,39 & 419,37 & 402,69 & 363,99 & 590,18 & 818,51 & 399,65 & 451,76 \\
\hline 266 & 017081bresser & 156,10 & 344,62 & 703,07 & 402,69 & 526,41 & 2280,23 & 1349,51 & 658,99 & 723,72 \\
\hline 267 & 017081cel emidio & 93,66 & 295,39 & 209,40 & 402,69 & 255,81 & 605,23 & 464,10 & 355,79 & 417,04 \\
\hline 268 & 017081gu bresser & 312,21 & 295,39 & 209,40 & 200,04 & 201,56 & 476,98 & 401,86 & 354,81 & 415,89 \\
\hline 269 & 017081j boemer & 93,66 & 295,39 & 419,37 & 402,69 & 255,81 & 605,23 & 464,10 & 355,79 & 417,04 \\
\hline 270 & 017081ju bresser & 312,21 & 295,39 & 209,40 & 200,04 & 201,56 & 476,98 & 362,72 & 354,20 & 415,17 \\
\hline 271 & 017081silva telles & 104,07 & 295,39 & 467,78 & 402,69 & 458,90 & 2254,71 & 916,56 & 570,99 & 628,06 \\
\hline 272 & 017083alexandrino & 93,66 & 246,16 & 351,26 & 335,85 & 268,32 & 589,52 & 492,57 & 336,71 & 457,20 \\
\hline 273 & 017083tiers & 83,26 & 295,39 & 374,33 & 357,89 & 251,46 & 601,30 & 402,12 & 336,02 & 457,20 \\
\hline 274 & 017083vautier & 104,07 & 295,39 & 467,78 & 449,85 & 282,78 & 708,60 & 418,39 & 335,82 & 457,20 \\
\hline 275 & 017083vitor hugo & 78,05 & 246,16 & 351,26 & 335,85 & 241,90 & 589,52 & 418,26 & 335,82 & 457,20 \\
\hline 276 & 017084alexandrino & 78,05 & 246,16 & 351,26 & 335,85 & 268,10 & 589,52 & 446,25 & 336,17 & 457,20 \\
\hline 277 & 017084rodrigues san & 93,66 & 295,39 & 419,37 & 402,69 & 268,10 & 641,21 & 391,61 & 336,40 & 457,20 \\
\hline 278 & 017084tiers & 83,26 & 295,39 & 374,33 & 357,89 & 251,46 & 601,30 & 464,10 & 336,40 & 457,20 \\
\hline 279 & 017084vitor hugo & 78,05 & 246,16 & 351,26 & 335,85 & 246,57 & 558,77 & 464,59 & 336,40 & 457,20 \\
\hline 280 & 017085j teodoro & 104,07 & 295,39 & 549,96 & 525,93 & 365,94 & 679,82 & 594,87 & 315,85 & 406,51 \\
\hline 281 & 017085tiers & 83,26 & 295,39 & 374,33 & 357,89 & 341,27 & 601,30 & 772,21 & 376,97 & 426,13 \\
\hline 282 & 017085vautier & 104,07 & 295,39 & 467,78 & 449,85 & 376,71 & 613,73 & 851,15 & 415,55 & 469,74 \\
\hline 283 & 017085vitor hugo & 78,05 & 246,16 & 351,26 & 335,85 & 344,85 & 558,77 & 464,59 & 378,36 & 427,70 \\
\hline 284 & 017086 manuel d h ? & & 0,00 & 351,26 & & & & 851,15 & 354,80 & \\
\hline 285 & 017088b ladario & 145,70 & 295,39 & 419,37 & 402,69 & 363,99 & 0,18 & 794,57 & 388,00 & 438,59 \\
\hline 286 & 017088j teodoro & 104,07 & 295,39 & 549,96 & 525,93 & 365,94 & 679,82 & 566,37 & 307,06 & 392,71 \\
\hline 287 & 017088pe bento & 130,09 & 295,39 & 585,43 & 559,59 & 415,85 & 673,93 & 922,65 & 450,56 & 509,32 \\
\hline 288 & 017088rodrigues san & 93,66 & 295,39 & 421,06 & 402,69 & 363,99 & 641,21 & 391,61 & 357,66 & 438,59 \\
\hline 289 & 017089b ladario & 145,70 & 295,39 & 421,06 & 402,69 & 363,99 & 590,18 & 818,51 & 399,65 & 438,59 \\
\hline 290 & 017089j teodoro & 104,07 & 295,39 & 467,78 & 449,85 & 337,57 & 636,63 & 593,35 & 315,85 & 406,51 \\
\hline 291 & 017089m marcolina & 104,07 & 295,39 & 467,78 & 449,85 & 378,66 & 613,73 & 851,15 & 415,55 & 469,74 \\
\hline 292 & 017089miller & 104,07 & 295,39 & 419,93 & 402,69 & 363,77 & 590,18 & 818,51 & 459,62 & 519,57 \\
\hline 293 & 017089ornelas & 104,07 & 295,39 & 419,37 & 402,69 & 363,77 & 590,18 & 818,51 & 379,60 & 445,33 \\
\hline 294 & 017089pe bento & 130,09 & 295,39 & 585,43 & 559,59 & 415,85 & 673,93 & 922,65 & 450,56 & 509,32 \\
\hline 295 & 017090j teodoro & 156,10 & 787,71 & 698,01 & 435,16 & 407,04 & 768,15 & 661,96 & 352,95 & 453,77 \\
\hline 296 & 017090m marcolina & 104,07 & 295,39 & 467,78 & 447,72 & 378,66 & 613,73 & 851,15 & 415,55 & 469,74 \\
\hline 297 & 017090miller & 93,66 & 295,39 & 419,37 & 402,69 & 363,99 & 590,18 & 818,51 & 459,62 & 519,57 \\
\hline 298 & $017091 \mathrm{~m}$ sobral & & 0,00 & & 447,72 & 378,66 & 613,73 & 851,15 & 0,00 & \\
\hline 299 & 017091casimiro & 93,66 & 295,39 & 419,37 & 402,69 & 363,12 & 590,18 & 818,51 & 399,65 & 451,76 \\
\hline 300 & 017091j teodoro & 104,07 & 787,71 & 698,01 & 435,16 & 455,42 & 738,05 & 906,44 & 442,63 & 500,35 \\
\hline 301 & 017091paraiba & 83,26 & 246,16 & 373,21 & 357,89 & 267,55 & 632,71 & 388,82 & 378,66 & 443,83 \\
\hline 302 & 017091silva telles & 156,10 & 393,85 & 698,01 & 435,16 & 557,18 & 4630,46 & 975,18 & 572,91 & 629,19 \\
\hline 303 & 017092casimiro & 93,66 & 295,39 & 421,06 & 402,69 & 363,12 & 590,18 & 818,51 & 395,81 & 451,76 \\
\hline 304 & 017092mendes & 93,66 & 295,39 & 421,06 & 402,69 & 363,99 & 590,18 & 818,51 & 399,65 & 451,76 \\
\hline 305 & 017092paraiba & 93,66 & 246,16 & 374,33 & 357,89 & 267,55 & 2667,57 & 464,23 & 378,66 & 444,80 \\
\hline 306 & 017092silva telles & 156,10 & 393,85 & 703,07 & 672,17 & 557,18 & 590,18 & 1001,06 & 572,91 & 629,19 \\
\hline 307 & 017093e rudge & 312,21 & 393,85 & 421,06 & 402,69 & 363,99 & 590,18 & 818,51 & 399,65 & 451,76 \\
\hline 308 & 017093mendes gon & 93,66 & 295,39 & 421,06 & 402,69 & 363,99 & 590,18 & 818,51 & 399,65 & 451,76 \\
\hline
\end{tabular}




\begin{tabular}{|c|c|c|c|c|c|c|c|c|c|c|}
\hline 309 & \begin{tabular}{|l} 
017093mendes \\
junior
\end{tabular} & 93,66 & 295,39 & 421,06 & 402,69 & 363,99 & 590,18 & 818,51 & 399,65 & 451,76 \\
\hline 310 & 017093silva telles & 156,10 & 393,85 & 703,07 & 435,16 & 557,18 & 2667,57 & 1001,06 & 572,91 & 629,19 \\
\hline 311 & 017094bresser & 156,10 & 344,62 & 703,07 & 388,23 & 526,41 & 2280,23 & 1458,86 & 712,49 & 312,22 \\
\hline 312 & 017094cel emidio & 93,66 & 295,39 & 421,06 & 402,69 & 363,99 & 590,18 & 818,51 & 399,65 & 451,76 \\
\hline 313 & 017094mendes gon & 93,66 & 295,39 & 703,07 & 402,69 & 363,99 & 590,18 & 818,51 & 399,65 & 451,76 \\
\hline 314 & 017094silva telles & 156,10 & 393,85 & 703,07 & 672,17 & 557,18 & 2667,57 & 1001,06 & 572,91 & 629,19 \\
\hline 315 & 017096aparecida & 20,81 & 78,77 & 93,44 & 89,12 & 143,83 & 340,23 & 310,70 & 353,66 & 322,58 \\
\hline 316 & 017096bom jardim & 20,81 & 196,93 & 356,88 & 335,85 & 241,14 & 570,55 & 620,04 & 358,25 & 419,92 \\
\hline 317 & 017096cachoeira & 72,85 & 196,93 & 327,05 & 402,69 & 235,27 & 605,23 & 401,73 & 354,80 & 415,86 \\
\hline 318 & 017096cap passos & 93,66 & 147,69 & 421,06 & 402,69 & 255,81 & 605,23 & 349,81 & 353,99 & 414,92 \\
\hline 319 & 017096sacramento & 93,66 & 78,77 & 93,44 & 89,12 & 143,83 & 5574,61 & 310,89 & 352,80 & 322,19 \\
\hline 320 & 017097j teodoro & 416,28 & 787,71 & 549,96 & 525,93 & 365,94 & 679,82 & 443,01 & 303,39 & 390,47 \\
\hline 321 & 017097rodrigues san & 312,21 & 295,39 & 421,06 & 402,69 & 363,99 & 590,18 & 349,78 & 388,00 & 281,84 \\
\hline 322 & 017097tiers & 364,24 & 295,39 & 374,33 & 357,89 & 343,44 & 556,81 & 587,81 & 357,39 & 404,00 \\
\hline 323 & 017097vitor hugo & 156,10 & 246,16 & 351,26 & 335,85 & 344,85 & 558,77 & 693,44 & 356,77 & 405,47 \\
\hline 324 & $017101 \mathrm{~s}$ biaggio & 78,05 & 88,62 & 93,44 & 89,12 & 143,83 & 449,50 & 305,36 & 194,38 & 321,26 \\
\hline 325 & 01710 & 88,46 & 147,69 & 163,24 & 162,83 & 169,27 & 519,51 & 501,11 & 244,54 & 286,64 \\
\hline 326 & 017101Ester m. b. & 78,05 & 78,77 & 93,44 & 89,12 & 143,83 & 422,68 & 440,52 & 214,83 & 251,79 \\
\hline 327 & 017101frei pacífico & 72,85 & 88,62 & 93,44 & 89,12 & 143,83 & 416,79 & 359,29 & 196,95 & 230,85 \\
\hline 328 & 017101g leingrub & 72,85 & 78,77 & 93,44 & 89,12 & 252,55 & 449,50 & 305,26 & 196,36 & 230,16 \\
\hline 329 & 017101guidemar & 72,85 & 78,77 & 93,44 & 89,12 & 143,83 & 456,05 & 305,36 & 196,36 & 322,19 \\
\hline 330 & 017101morro grande & 72,85 & 78,77 & 93,44 & 89,12 & 143,83 & 449,50 & 359,35 & 22,81 & 322,19 \\
\hline 331 & pardal & 72,85 & 78,77 & 93,44 & 89,12 & 143,83 & 449,50 & 440,49 & 214,83 & 251,79 \\
\hline 332 & e vieira & 88,46 & 147,69 & 93,44 & 155,72 & 169,27 & 519,51 & 463,36 & 226,06 & 9,95 \\
\hline 333 & 017101sacramento & 72,85 & 78,77 & 93,44 & 89,12 & 143,83 & 449,50 & 359,35 & 196,95 & 322,19 \\
\hline 334 & 017102antonio a & 72,85 & 78,77 & 81,06 & 110,69 & 154,60 & 466,51 & 305,46 & 196,36 & 230,16 \\
\hline 335 & 017102aparecida & 72,85 & 78,77 & 109,20 & 89,12 & 143,83 & 449,50 & 359,35 & 196,74 & 322,58 \\
\hline 336 & 017102araguaia & 72,85 & 147,69 & 93,44 & 110,69 & 154,60 & 478,95 & 501,08 & 244,54 & 286,64 \\
\hline 337 & 017102bom jardim & 78,05 & 147,69 & 93,44 & 335,85 & 212,76 & 639,25 & 626,34 & 356,77 & 322,67 \\
\hline 338 & 017102frei pacífico & 72,85 & 88,62 & 93,44 & 89,12 & 132,96 & 416,79 & 413,61 & 201,74 & 236,46 \\
\hline 339 & 017102iturama & 72,85 & 78,77 & 109,20 & 223,27 & 98,82 & 354,63 & 231,24 & 98,05 & 114,91 \\
\hline 340 & 017102pardal & 72,85 & 78,77 & 109,20 & 89,12 & 143,83 & 449,50 & 440,49 & 214,83 & 251,79 \\
\hline 341 & 017102sacramento & 72,85 & 78,77 & 93,44 & 89,12 & 143,83 & 449,50 & 305,36 & 196,36 & 230,16 \\
\hline 342 & 017102sem denom & 72,85 & 78,77 & 93,44 & 200,04 & 154,60 & 449,50 & 440,46 & 214,83 & 250,85 \\
\hline 343 & 017103azurita & 72,85 & 147,69 & 93,44 & 110,69 & 154,60 & 478,95 & 440,46 & 214,83 & 304,11 \\
\hline 344 & 017103castelo & 52,03 & 147,69 & 234,17 & 223,50 & 184,39 & 560,73 & 531,46 & 259,46 & 250,85 \\
\hline 345 & 017103elias & 83,26 & 49,23 & 109,20 & 223,50 & 154,60 & 478,95 & 440,46 & 214,83 & 251,79 \\
\hline 346 & 017103pascoal ranie & 83,26 & 49,23 & 139,60 & 133,44 & 160,47 & 495,30 & 500,95 & 244,54 & 286,64 \\
\hline 347 & ponta cruz & 78,05 & 49,23 & 115,96 & 110,69 & 154,60 & 473,06 & 426,22 & 214,83 & 251,79 \\
\hline 348 & 017103sem denom & & 0,00 & 93,44 & 110,69 & 154,60 & 478,95 & 440,46 & 214,83 & 251,79 \\
\hline 349 & 017103zilda macedo & & 0,00 & 115,96 & 110,69 & 154,60 & 492,03 & 440,46 & 214,83 & 251,79 \\
\hline 350 & 017104araguaia & 78,05 & 0,00 & 139,60 & 110,69 & 160,25 & 495,30 & 501,05 & 214,83 & 286,64 \\
\hline 351 & 017104caninde & 78,05 & 0,00 & 93,44 & 138,18 & 160,47 & 495,30 & 508,62 & 248,24 & 290,98 \\
\hline 352 & 017104carnot & 52,03 & 0,00 & 139,60 & 223,27 & 160,47 & 495,30 & 440,46 & 215,08 & 251,79 \\
\hline 353 & 017104pedro vicente & 78,05 & 0,00 & 139,60 & 133,44 & 160,47 & 495,30 & 440,46 & 215,08 & 252,10 \\
\hline 354 & 017105araguaia & 83,26 & 0,00 & 139,60 & 133,44 & 160,47 & 495,30 & 463,33 & 226,06 & 340,29 \\
\hline 355 & 017105carnot & 83,26 & 0,00 & 139,60 & 133,44 & 160,47 & 495,30 & 440,46 & 215,08 & 252,10 \\
\hline 356 & $017105 \mathrm{com}$ nestor $p$ & & 0,00 & & & & & & 132,61 & 114,79 \\
\hline 357 & 017105elias & 78,05 & 0,00 & & 110,69 & 154,60 & 478,95 & 440,46 & 214,83 & 251,79 \\
\hline 358 & 017105olarias & 78,05 & 0,00 & & 110,69 & 154,60 & 478,95 & 413,44 & 201,74 & 236,46 \\
\hline 359 & 017105pedro vicente & 83,26 & 0,00 & & 133,44 & 160,47 & 495,30 & 440,46 & 215,08 & 252,10 \\
\hline 360 & 017105piscina & 78,05 & 0,00 & & 110,69 & 160,47 & 478,95 & 195,59 & 0,00 & 252,10 \\
\hline
\end{tabular}




\begin{tabular}{|c|c|c|c|c|c|c|c|c|c|c|}
\hline 361 & 017105sem denom & & 0,00 & & 110,69 & 154,60 & 478,95 & 440,46 & 214,83 & 251,79 \\
\hline 362 & 017106 j feliciano & 78,05 & 0,00 & 115,96 & 110,69 & 154,60 & 478,95 & 485,91 & 237,05 & 277,86 \\
\hline 363 & 017106azurita & 78,05 & 0,00 & 115,96 & 110,69 & 154,60 & 478,95 & 463,17 & 214,83 & 264,97 \\
\hline 364 & 017106castelo & 52,03 & 0,00 & 233,61 & 223,50 & 184,39 & 560,73 & 440,46 & 214,83 & 251,79 \\
\hline 365 & 017106mons maxi & & 0,00 & 115,96 & 158,09 & 69,47 & 249,29 & 223,58 & 94,78 & 111,09 \\
\hline 366 & 017107castelo & 78,05 & 0,00 & 233,61 & 223,27 & 98,61 & 354,63 & 228,27 & 111,37 & 130,54 \\
\hline 367 & 017107faustino & 78,05 & 0,00 & 115,96 & 110,69 & 69,47 & 249,29 & 223,58 & 94,78 & 111,09 \\
\hline 368 & 017107felisberto & 78,05 & 0,00 & 115,96 & 110,69 & 69,47 & 249,29 & 223,58 & 94,78 & 111,09 \\
\hline 369 & 017107mons maxi & 78,05 & 0,00 & 115,96 & 110,69 & 69,47 & 249,29 & 242,99 & 98,05 & 114,91 \\
\hline 370 & 017108faustino & 78,05 & 49,23 & 115,96 & 110,69 & 69,47 & 249,29 & 223,58 & 94,78 & 111,09 \\
\hline 371 & 017108felisberto & 78,05 & 68,92 & 115,96 & 110,69 & 69,47 & 249,29 & 310,92 & 94,78 & 111,09 \\
\hline 372 & 017108j feliciano & 78,05 & 0,00 & 115,96 & 110,69 & 69,47 & 249,29 & 228,24 & 94,76 & 111,09 \\
\hline 373 & 017108mons maxi & 78,05 & 0,00 & 115,96 & 158,09 & 69,47 & 249,29 & 223,58 & 94,78 & 111,09 \\
\hline 374 & $017109 \mathrm{j}$ feliciano & 78,05 & 49,23 & 115,96 & 110,69 & 69,47 & 326,49 & 228,24 & 96,61 & 113,22 \\
\hline 375 & 017109 r f carvalho & 78,05 & 88,62 & 115,96 & & & & & & \\
\hline 376 & 017109araguaia & 78,05 & 0,00 & 115,96 & 110,69 & 154,60 & 478,95 & 359,45 & 196,95 & 230,85 \\
\hline 377 & 017109felisberto & 78,05 & 0,00 & 115,96 & 110,69 & 69,47 & 249,29 & 223,58 & 94,78 & 111,09 \\
\hline 378 & 017110bom jardim & 78,05 & 0,00 & 351,26 & 335,85 & 212,76 & 639,25 & 493,67 & 241,02 & 282,51 \\
\hline 379 & 017110castelo & 52,03 & 0,00 & 233,61 & 312,86 & 154,05 & 627,47 & 440,52 & 214,83 & 251,79 \\
\hline 380 & 017110guaranta & 52,03 & 0,00 & 233,61 & 223,27 & 184,39 & 560,73 & 386,46 & 197,26 & 231,19 \\
\hline 381 & 017110miguel paulo & & 0,00 & 233,61 & 223,27 & 184,39 & 560,73 & 486,01 & 197,26 & 278,13 \\
\hline 382 & 017110nsra oliveira & 52,03 & 0,00 & 327,05 & 312,86 & 162,75 & 627,47 & 522,69 & 214,83 & 251,79 \\
\hline 383 & 017111 ilo otani & 104,07 & 196,93 & 467,78 & 447,48 & 242,66 & 721,69 & 440,68 & 215,08 & 251,79 \\
\hline 384 & 017111bom jardim & 78,05 & 147,69 & 351,26 & 335,85 & 212,76 & 639,25 & 381,45 & 233,55 & 273,75 \\
\hline 385 & 017111guaranta & 52,03 & 0,00 & 233,61 & 223,27 & 184,39 & 560,73 & 493,48 & 240,83 & 282,28 \\
\hline 386 & 017111min francisco & 52,03 & 0,00 & 233,61 & 223,27 & 184,39 & 560,73 & 440,52 & 214,83 & 251,79 \\
\hline 387 & 017112 ilo otani & 104,07 & 196,93 & 467,78 & 447,48 & 242,66 & 721,69 & 440,68 & 215,08 & 251,79 \\
\hline 388 & 017112antonio $\mathrm{m}$ & 52,03 & 0,00 & 351,26 & 312,86 & 154,05 & 627,47 & 440,52 & 214,83 & 251,79 \\
\hline 389 & 017112carlos & 52,03 & 196,93 & 351,26 & 335,85 & 212,76 & 560,73 & 561,64 & 274,22 & 321,42 \\
\hline 390 & 017112castelo & 72,85 & 147,69 & & 312,86 & 208,41 & 601,95 & 440,52 & 214,83 & 251,88 \\
\hline 391 & 017112min francisco & 52,03 & 0,00 & & 223,27 & 184,39 & 570,55 & 440,52 & 214,83 & 251,79 \\
\hline 392 & 017113 ilo otani & 104,07 & 196,93 & & 447,48 & 273,97 & 556,15 & 588,98 & 357,77 & 419,34 \\
\hline 393 & 017113carlos & 78,05 & 196,93 & & 335,85 & 241,14 & 556,15 & 479,83 & 356,04 & 415,77 \\
\hline 394 & 017113cel emidio & 72,85 & 196,93 & & 312,86 & 235,27 & 605,23 & 464,17 & 355,79 & 417,04 \\
\hline 395 & 017113pedroso & 93,66 & 196,93 & & 402,69 & 255,81 & 605,23 & 448,54 & 355,56 & 416,77 \\
\hline 396 & 017113rodovalho & 78,05 & 196,93 & & 335,85 & 241,14 & 570,55 & 448,54 & 353,99 & 414,92 \\
\hline 397 & 017113siqueira a & 78,05 & 0,00 & & 223,27 & 201,56 & 476,98 & 499,79 & 356,29 & 417,62 \\
\hline 398 & 017114castelo & 78,05 & 0,00 & & & 152,64 & 470,44 & 418,91 & 243,21 & 250,18 \\
\hline 399 & 017114m ybarra & 78,05 & 0,00 & & & 145,79 & 448,85 & 353,08 & 232,71 & 239,34 \\
\hline 400 & 017114paulo andrig & 78,05 & 0,00 & & & 187,32 & 448,85 & 439,68 & 255,44 & 262,75 \\
\hline 401 & 017114silva telles & 78,05 & 0,00 & & & 145,79 & 448,85 & 481,19 & 279,58 & 303,25 \\
\hline 402 & 017115m ybarra & 78,05 & 0,00 & & & 145,79 & 448,85 & 353,08 & 232,71 & 239,34 \\
\hline 403 & 017115paulo andrig & 78,05 & 0,00 & & & 187,32 & 577,09 & 395,84 & 233,21 & 239,88 \\
\hline 404 & 017115silva telles & 78,05 & 0,00 & & & 145,79 & 448,85 & 353,08 & 232,71 & 250,32 \\
\hline 405 & 018026cruzeiro & 208,14 & 246,16 & 355,20 & 447,48 & 166,34 & 413,52 & 223,87 & 136,05 & 198,13 \\
\hline 406 & 018026manuel ant & 208,14 & 167,39 & 327,05 & 312,86 & 129,59 & 312,10 & 162,95 & 134,09 & 198,13 \\
\hline 407 & 018026pedro vicen & 208,14 & 196,93 & 351,26 & 335,85 & 136,01 & 329,77 & 209,02 & 132,78 & 198,13 \\
\hline 408 & 018039caninde & 260,17 & 98,46 & 467,78 & 133,44 & 56,21 & 338,27 & 191,45 & 123,66 & 198,13 \\
\hline 409 & 018039cruzeiro & 208,14 & 246,16 & 233,61 & 447,48 & 166,34 & 413,52 & 235,13 & 138,48 & 198,13 \\
\hline 410 & 018039manuel ant & 208,14 & 167,39 & 327,05 & 312,86 & 129,59 & 312,10 & 171,88 & 124,52 & 198,13 \\
\hline 411 & 018039vidal neg & 208,14 & 196,93 & 233,61 & 223,27 & 94,37 & 215,26 & 168,16 & 126,21 & 198,13 \\
\hline 412 & 018040araguaia & 182,12 & 98,46 & 233,61 & 133,44 & 56,21 & 150,49 & 179,32 & 126,21 & 198,13 \\
\hline
\end{tabular}




\begin{tabular}{|c|c|c|c|c|c|c|c|c|c|c|}
\hline 413 & 018040caninde & 260,17 & 147,69 & 233,61 & 223,27 & 94,37 & 567,93 & 1843,64 & 126,94 & 198,13 \\
\hline 414 & 018040carnot & 260,17 & 98,46 & 233,61 & 223,27 & 94,04 & 215,26 & 163,05 & 122,57 & 198,13 \\
\hline 415 & 018040itaqui & 260,17 & 147,69 & 209,40 & 200,04 & 84,58 & 188,44 & 166,32 & 123,66 & 198,13 \\
\hline 416 & 018041carnot & 208,14 & 98,46 & 233,61 & 223,27 & 94,37 & 212,65 & 157,84 & 121,41 & 198,13 \\
\hline 417 & 018041itaqui & 208,14 & 147,69 & 209,40 & 200,04 & 84,58 & 188,44 & 168,16 & 123,66 & 198,13 \\
\hline 418 & 018041quixelos & 182,12 & 98,46 & 209,40 & 200,04 & 84,58 & 188,44 & 152,70 & 120,30 & 198,13 \\
\hline 419 & 018042araguaia & 182,12 & 98,46 & 136,22 & 133,44 & 56,21 & 150,49 & 142,41 & 117,98 & 194,03 \\
\hline 420 & 018042carnot & 260,17 & 98,46 & 233,61 & 223,27 & 94,37 & 215,26 & 147,33 & 119,49 & 196,08 \\
\hline 421 & 018042pascoal mala & 182,12 & 147,69 & 209,40 & 200,04 & 84,37 & 188,44 & 142,44 & 117,98 & 194,03 \\
\hline 422 & 018042quixelos & 182,12 & 147,69 & 212,78 & 200,04 & 84,37 & 188,44 & 152,70 & 117,98 & 194,03 \\
\hline 423 & 018043itaqui & 260,17 & 196,93 & 351,26 & 200,04 & 136,01 & 329,77 & 168,09 & 129,27 & 198,13 \\
\hline 424 & 018043juruá & 260,17 & 196,93 & 351,26 & 335,85 & 136,01 & 329,77 & 152,76 & 120,30 & 198,13 \\
\hline 425 & 018043olarias & 182,12 & 246,16 & 233,61 & 223,27 & 94,37 & 280,69 & 147,49 & 119,23 & 196,08 \\
\hline 426 & 018043pascoal mala & 182,12 & 147,69 & 209,40 & 200,04 & 84,37 & 188,44 & 142,44 & 117,98 & 194,03 \\
\hline 427 & 018043quixelos & 182,12 & 98,46 & 209,40 & 200,04 & 84,58 & 188,44 & 142,41 & 117,98 & 194,03 \\
\hline 428 & 018057afonso & 234,16 & 196,93 & 233,61 & 223,27 & 94,37 & 215,26 & 194,10 & 110,18 & 194,03 \\
\hline 429 & 018057cruzeiro & 260,17 & 246,16 & 467,78 & 447,48 & 166,34 & 413,52 & 223,87 & 136,05 & 198,13 \\
\hline 430 & 018057itariri & 208,14 & 196,93 & 233,61 & 223,27 & 94,37 & 215,26 & 152,73 & 120,30 & 197,84 \\
\hline 431 & 018057vidal neg & 208,14 & 196,93 & 233,61 & 223,27 & 94,37 & 215,26 & 194,10 & 120,30 & 198,13 \\
\hline 432 & 018058afonso ari & 208,14 & 196,93 & 233,61 & 223,27 & 94,37 & 215,26 & 186,76 & 127,81 & 198,13 \\
\hline 433 & 018058itariri & 208,14 & 196,93 & 233,61 & 223,27 & 94,37 & 215,26 & 163,05 & 122,57 & 198,13 \\
\hline 434 & madeira & 208,14 & 147,69 & 233,61 & 223,27 & 94,37 & 215,26 & 153,70 & 120,30 & 197,84 \\
\hline 435 & 018058vidal neg & 208,14 & 196,93 & 209,40 & 200,04 & 84,58 & 186,47 & 168,16 & 120,30 & 198,13 \\
\hline 436 & 018059afonso ari & 208,14 & 196,93 & 233,61 & 223,27 & 94,37 & 215,26 & 194,10 & 129,38 & 198,13 \\
\hline 437 & 018059caninde & 260,17 & 196,93 & 233,61 & 268,30 & 113,50 & 215,26 & 186,73 & 127,81 & 198,13 \\
\hline 438 & 018059madeira & 208,14 & 196,93 & 233,61 & 223,27 & 94,37 & 215,26 & 152,73 & 125,37 & 198,13 \\
\hline 439 & 018059vidal negr & 208,14 & 196,93 & 209,40 & 200,04 & 84,58 & 186,47 & 157,81 & 125,37 & 198,13 \\
\hline 440 & 018060caninde & 260,17 & 177,23 & 233,61 & 223,27 & 94,37 & 268,26 & 186,76 & 127,81 & 198,13 \\
\hline 441 & 018060carnot & 156,10 & 196,93 & 233,61 & 223,27 & 94,37 & 215,26 & 194,10 & 129,38 & 198,13 \\
\hline 442 & 018060cons dantas & 260,17 & 147,69 & 233,61 & 223,27 & 94,37 & 215,26 & 186,76 & 125,89 & 198,13 \\
\hline 443 & 018060itaqui & 208,14 & 147,69 & 209,40 & 200,04 & 84,58 & 188,44 & 168,16 & 123,66 & 198,13 \\
\hline 444 & 018061carnot & 260,17 & 196,93 & 233,61 & 223,27 & 94,37 & 215,26 & 182,72 & 126,94 & 198,13 \\
\hline 445 & 018061cons dantas & 260,17 & 196,93 & 233,61 & 223,27 & 94,37 & 215,26 & 171,88 & 124,52 & 198,13 \\
\hline 446 & 018061itaqui & 208,14 & 147,69 & 209,40 & 200,04 & 84,58 & 188,44 & 171,88 & 124,52 & 198,13 \\
\hline 447 & 018061vautier & 312,21 & 295,39 & 233,61 & 1094,29 & 136,01 & 329,77 & 205,27 & 131,94 & 198,13 \\
\hline 448 & 018072afonso ari & 208,14 & 196,93 & 233,61 & 223,27 & 94,37 & 215,26 & 171,88 & 124,52 & 198,13 \\
\hline 449 & 018072cruzeiro & 260,17 & 246,16 & 467,78 & 447,48 & 353,22 & 591,48 & 574,07 & 351,93 & 351,99 \\
\hline 450 & 018072itariri & 208,14 & 196,93 & 233,61 & 223,27 & 243,64 & 407,63 & 439,84 & 331,41 & 331,45 \\
\hline 451 & 018072pasteur & 208,14 & 196,93 & 186,89 & 178,47 & 134,81 & 325,84 & 373,75 & 321,86 & 321,91 \\
\hline 452 & 018073afonso arinos & 208,14 & 196,93 & 233,61 & 223,27 & 94,37 & 215,26 & 194,10 & 129,38 & 198,13 \\
\hline 453 & 018073caninde & 156,10 & 196,93 & 233,61 & 268,30 & 113,50 & 268,26 & 186,76 & 127,81 & 198,13 \\
\hline 454 & 018073itariri & 208,14 & 196,93 & 233,61 & 223,27 & 243,64 & 407,63 & 447,61 & 323,04 & 323,08 \\
\hline 455 & 018073pasteur & 208,14 & 196,93 & 280,89 & 178,47 & 194,71 & 325,84 & 451,88 & 323,11 & 323,16 \\
\hline 456 & 018074camomil & 260,17 & 147,69 & 233,61 & 268,30 & 124,16 & 268,26 & 220,05 & 120,30 & 198,13 \\
\hline 457 & 018074caninde & 260,17 & 196,93 & 233,61 & 268,30 & 113,50 & 268,26 & 194,10 & 129,50 & 198,13 \\
\hline 458 & 018074carnot & 260,17 & 196,93 & 280,89 & 312,86 & 94,37 & 215,26 & 162,95 & 122,57 & 198,13 \\
\hline 459 & 018074cons dantas & 260,17 & 147,69 & 233,61 & 223,27 & 94,37 & 215,26 & 175,12 & 124,52 & 198,13 \\
\hline 460 & 018075camomil & 260,17 & 147,69 & 233,61 & 268,30 & 124,16 & 312,10 & 147,65 & 119,23 & 199,22 \\
\hline 461 & 018075carnot & 260,17 & 196,93 & 327,05 & 312,86 & 124,16 & 215,26 & 186,70 & 127,81 & 198,13 \\
\hline 462 & 018075 cons dantas & 260,17 & 147,69 & 233,61 & 223,27 & 94,37 & 215,26 & 186,83 & 127,81 & 198,13 \\
\hline 463 & 018075vautier & 312,21 & 196,93 & 351,26 & 383,25 & 136,01 & 329,77 & 209,02 & 132,78 & 198,13 \\
\hline 464 & 018076camomil & 260,17 & 147,69 & 233,61 & 268,30 & 94,37 & 268,26 & 147,33 & 122,57 & 198,13 \\
\hline
\end{tabular}




\begin{tabular}{|c|c|c|c|c|c|c|c|c|c|c|}
\hline 465 & 018076caninde & 260,17 & 196,93 & 233,61 & 268,30 & 113,50 & 268,26 & 194,10 & 129,50 & 198,13 \\
\hline 466 & 018076carnot & 260,17 & 196,93 & 327,05 & 312,86 & 124,16 & 312,10 & 186,70 & 129,38 & 198,13 \\
\hline 467 & 018076hannemann & 260,17 & 196,93 & 280,89 & 268,30 & 113,50 & 268,26 & 194,10 & 129,50 & 198,13 \\
\hline 468 & 018077camomil & 260,17 & 147,69 & 233,61 & 268,30 & 181,02 & 312,10 & 418,23 & 335,82 & 457,20 \\
\hline 469 & 018077carnot & 260,17 & 196,93 & 327,05 & 312,86 & 124,16 & 312,10 & 175,60 & 125,37 & 198,13 \\
\hline 470 & 018077hannemann & 260,17 & 196,93 & 280,89 & 268,30 & 221,13 & 528,67 & 446,18 & 336,17 & 457,20 \\
\hline 471 & 018077vautier & 312,21 & 196,93 & 421,06 & 383,25 & 268,10 & 641,21 & 452,52 & 336,17 & 457,20 \\
\hline 472 & 018078alexandrino & 260,17 & 196,93 & 304,53 & 291,05 & 122,74 & 293,13 & 183,04 & 126,94 & 198,13 \\
\hline 473 & 018078caninde & 312,21 & 196,93 & 233,61 & 268,30 & 113,50 & 268,26 & 186,73 & 127,81 & 198,13 \\
\hline 474 & 018078carnot & 260,17 & 246,16 & 327,05 & 312,86 & 124,16 & 312,10 & 205,36 & 131,94 & 198,13 \\
\hline 475 & 018078hannemann & 260,17 & 196,93 & 280,89 & 268,30 & 124,16 & 268,26 & 194,10 & 129,50 & 198,13 \\
\hline 476 & 018079alexandrino & 260,17 & 196,93 & 304,53 & 291,05 & 228,96 & 293,13 & 418,33 & 335,82 & 457,20 \\
\hline 477 & 018079carnot & 312,21 & 246,16 & 327,05 & 312,86 & 124,16 & 312,10 & 175,60 & 125,37 & 198,13 \\
\hline 478 & 018079hannemann & 260,17 & 196,93 & 280,89 & 268,30 & 221,13 & 528,67 & 427,61 & 335,82 & 457,20 \\
\hline 479 & 018079vautier & 364,24 & 196,93 & 421,06 & 402,69 & 268,10 & 641,21 & 511,05 & 337,19 & 457,20 \\
\hline 480 & 018082av estado & & 0,00 & 467,78 & 228,24 & 250,92 & 530,64 & 516,19 & 331,41 & 331,45 \\
\hline 481 & 018082caninde & 312,21 & 196,93 & 233,61 & 268,30 & 317,24 & 530,64 & 496,65 & 335,82 & 198,13 \\
\hline 482 & 018082pasteur & 260,17 & 196,93 & 186,89 & 43,37 & 195,47 & 325,84 & 451,88 & 32311,18 & 323,16 \\
\hline 483 & 018083caninde & 312,21 & 196,93 & 233,61 & 268,30 & 113,50 & 268,26 & 190,45 & 128,69 & 198,13 \\
\hline 484 & 018083carnot & 312,21 & 246,16 & 327,05 & 312,86 & 124,16 & 312,10 & 162,95 & 122,57 & 198,13 \\
\hline 485 & 018083pasteur & 260,17 & 196,93 & 233,61 & 312,86 & 124,16 & 325,84 & 451,88 & 129,27 & 198,13 \\
\hline 486 & or hugo & 260,17 & 196,93 & 304,53 & 291,05 & 219,18 & 293,13 & 152,73 & 322,25 & 197,84 \\
\hline 487 & 018084alexandrino & 260,17 & 196,93 & 209,40 & 295,32 & 124,16 & 325,84 & 474,10 & 336,50 & 331,45 \\
\hline 488 & 018084carnot & 312,21 & 246,16 & 327,05 & 312,86 & 235,59 & 312,10 & 427,58 & 335,94 & 457,20 \\
\hline 489 & 018084vautier & 364,24 & 295,39 & 421,06 & 402,69 & 268,10 & 641,21 & 501,86 & 336,92 & 457,20 \\
\hline 490 & 018084vitor hugo & 260,17 & 196,93 & 304,53 & 291,05 & 228,96 & 547,65 & 455,43 & 322,25 & 457,20 \\
\hline 491 & 018085caninde & 312,21 & 196,93 & 233,61 & 268,30 & 228,42 & 382,11 & 173,17 & 331,41 & 331,45 \\
\hline 492 & 018085carnot & 312,21 & 246,16 & 327,05 & 312,86 & 235,59 & 565,31 & 398,30 & 322,25 & 322,30 \\
\hline 493 & 018085herilio luz & 260,17 & 196,93 & 233,61 & 223,27 & 190,26 & 410,24 & 422,99 & 322,67 & 198,13 \\
\hline 494 & 018085vitor hugo & 260,17 & 196,93 & 304,53 & 291,05 & 247,55 & 414,17 & 430,62 & 322,25 & 322,30 \\
\hline 495 & 018086caninde & 364,24 & 196,93 & 233,61 & 268,30 & 228,42 & 382,11 & 529,94 & 340,12 & 340,17 \\
\hline 496 & 018086carnot & 364,24 & 246,16 & 327,05 & 312,86 & 255,05 & 436,42 & 447,51 & 323,04 & 323,08 \\
\hline 497 & 018086hercilio luz & 260,17 & 196,93 & 233,61 & 223,27 & 190,26 & 318,64 & 422,99 & 322,67 & 322,72 \\
\hline 498 & 018086joao teo & 416,28 & 295,39 & 549,96 & 525,93 & 360,51 & 679,82 & 550,74 & 304,89 & 392,40 \\
\hline 499 & 018087carnot & 364,24 & 246,16 & 327,05 & 312,86 & 151,99 & 436,42 & 522,40 & 338,24 & 338,29 \\
\hline 500 & 018087joao teo & 416,28 & 295,39 & 549,96 & 525,93 & 360,51 & 679,82 & 566,37 & 305,14 & 392,40 \\
\hline 501 & 018087vautier & 364,24 & 295,39 & 421,06 & 402,69 & 271,69 & 533,25 & 591,31 & 360,59 & 360,64 \\
\hline 502 & 018087vitor hugo & 260,17 & 196,93 & 304,53 & 291,05 & 247,55 & 414,17 & 522,37 & 322,25 & 338,29 \\
\hline 503 & 018091cruzeiro & 208,14 & 246,16 & 467,78 & 447,48 & 353,22 & 589,52 & 548,35 & 345,27 & 345,12 \\
\hline 504 & 018091paulino gui & & 147,69 & 383,34 & 312,86 & 295,49 & 612,42 & 201,13 & 131,34 & 198,13 \\
\hline 505 & 018098castelo & & 147,69 & 233,61 & 230,38 & 230,37 & 636,63 & 384,68 & 289,59 & 339,43 \\
\hline 506 & 018098cruzeiro & 208,14 & 246,16 & 351,26 & 447,48 & 235,27 & 636,63 & 366,79 & 289,59 & 339,43 \\
\hline 507 & 018099castelo & & 0,00 & 304,53 & 230,38 & 230,37 & 294,43 & 382,74 & 289,59 & 339,43 \\
\hline 508 & 018100castelo & & 0,00 & 304,53 & 230,38 & 206,46 & 294,43 & 293,32 & 215,18 & 339,43 \\
\hline 509 & 026066 paulo & 156,10 & 196,93 & 327,05 & 312,86 & 235,27 & 556,15 & 448,48 & 379,30 & 353,87 \\
\hline 510 & 026066 silva telles & 208,14 & 196,93 & 233,61 & 312,86 & 439,33 & 2102,91 & 766,29 & 567,88 & 444,60 \\
\hline 511 & 026066joaquim c & 156,10 & 196,93 & 327,05 & 312,86 & 235,27 & 556,15 & 495,23 & 379,78 & 623,65 \\
\hline 512 & 026066sta rita & 156,10 & 196,93 & 327,05 & 312,86 & 235,27 & 556,15 & 495,23 & 379,78 & 445,14 \\
\hline 513 & 026067joaquim c & 156,10 & 196,93 & 327,05 & 312,86 & 235,27 & 556,15 & 448,48 & 379,30 & 445,14 \\
\hline 514 & 026067rodovalho & 156,10 & 344,62 & 351,26 & 383,25 & 235,27 & 570,55 & 417,49 & 378,99 & 444,60 \\
\hline 515 & 026067sat rita & 156,10 & 196,93 & 327,05 & 312,86 & 235,27 & 556,15 & 401,47 & 378,78 & 445,14 \\
\hline 516 & 026067silva telles & 208,14 & 196,93 & 421,06 & 402,69 & 458,90 & 2065,62 & 805,73 & 569,24 & 625,16 \\
\hline
\end{tabular}




\begin{tabular}{|c|c|c|c|c|c|c|c|c|c|c|}
\hline 517 & 026068rodovalho & 156,10 & 196,93 & 351,26 & 335,85 & 235,27 & 570,55 & 417,88 & 378,78 & 443,98 \\
\hline 518 & 026068sat rita & 182,12 & 196,93 & 327,05 & 312,86 & 235,27 & 556,15 & 588,72 & 380,74 & 446,27 \\
\hline 519 & 026068silva telles & 208,14 & 196,93 & 419,37 & 378,99 & 458,90 & 2196,48 & 923,10 & 571,89 & 628,06 \\
\hline 520 & 026068siqueira a & 156,10 & 246,16 & 233,61 & 223,27 & 207,87 & 491,38 & 359,64 & 378,62 & 443,80 \\
\hline 521 & 026069pedroso & 208,14 & 246,16 & 421,06 & 400,55 & 147,10 & 605,23 & 495,23 & 378,62 & 445,14 \\
\hline 522 & 026069silva telles & 208,14 & 196,93 & 421,06 & 402,69 & 458,90 & 2196,48 & 805,79 & 569,24 & 625,16 \\
\hline 523 & 026069siqueira a & 156,10 & 246,16 & 233,61 & 223,27 & 207,87 & 491,38 & 401,83 & 378,62 & 443,80 \\
\hline 524 & 026069sta rita & 182,12 & 196,93 & 327,05 & 312,86 & 235,27 & 556,15 & 375,88 & 378,53 & 443,69 \\
\hline 525 & 026070godoi & 182,12 & 196,93 & 327,05 & 312,86 & 235,27 & 556,15 & 375,88 & 378,53 & 443,69 \\
\hline 526 & 026070pedroso & 208,14 & 246,16 & 421,06 & 400,55 & 277,56 & 605,23 & 495,23 & 379,78 & 445,14 \\
\hline 527 & 026070silva telles & 208,14 & 196,93 & 421,06 & 402,69 & 458,90 & 2196,48 & 1001,29 & 572,91 & 629,19 \\
\hline 528 & 026070sta rita & 182,12 & 196,93 & 421,06 & 402,69 & 255,81 & 605,23 & 388,70 & 378,66 & 443,83 \\
\hline 529 & 026071cachoeira & 260,17 & 196,93 & 419,37 & 402,69 & 255,81 & 605,23 & 388,70 & 378,66 & 443,83 \\
\hline 530 & 026071camilo & 208,14 & 147,69 & 209,40 & 312,86 & 201,56 & 476,98 & 375,66 & 378,53 & 443,69 \\
\hline 531 & 026071godoi & 182,12 & 196,93 & 327,05 & 312,86 & 235,27 & 556,15 & 401,73 & 378,78 & 600,74 \\
\hline 532 & 026071silva telles & 208,14 & 196,93 & 421,06 & 402,69 & 458,90 & 2196,48 & 727,60 & 566,50 & 622,13 \\
\hline 533 & 026072cachoeira & 260,17 & 196,93 & 421,06 & 378,99 & 147,10 & 605,23 & 464,10 & 379,47 & 444,80 \\
\hline 534 & 026072camilo & 208,14 & 147,69 & 209,40 & 312,86 & 201,56 & 476,98 & 375,66 & 378,53 & 443,69 \\
\hline 535 & 026072godoi preto & 130,09 & 196,93 & 327,05 & 312,86 & 235,27 & 556,15 & 375,88 & 378,53 & 443,69 \\
\hline 536 & 026072sta rita & 208,14 & 196,93 & 421,06 & 402,69 & 255,81 & 605,23 & 388,70 & 378,66 & 443,83 \\
\hline 537 & 026073cachoeira & 260,17 & 196,93 & 421,06 & 402,69 & 255,81 & 605,23 & 362,69 & 378,32 & 443,44 \\
\hline 538 & 026073rio bonito & 260,17 & 295,39 & 421,06 & 402,69 & 255,81 & 605,23 & 510,79 & 379,93 & 445,33 \\
\hline 539 & 026073silva telles & 260,17 & 295,39 & 421,06 & 402,69 & 458,90 & 2196,48 & 962,21 & 571,68 & 628,26 \\
\hline 540 & 026073sta rita & 260,17 & 295,39 & 421,06 & 402,69 & 255,81 & 605,23 & 388,70 & 378,66 & 554,97 \\
\hline 541 & 026074j boemer & 260,17 & 295,39 & 421,06 & 402,69 & 255,81 & 605,23 & 479,67 & 379,60 & 444,96 \\
\hline 542 & 026074rio bonito & 260,17 & 295,39 & 421,06 & 402,69 & 255,81 & 605,23 & 510,79 & 379,93 & 445,33 \\
\hline 543 & 026074silva telles & 260,17 & 295,39 & 421,06 & 40,06 & 458,90 & 2196,48 & 962,21 & 572,07 & 628,26 \\
\hline 544 & 026074sta rita & 260,17 & 295,39 & 421,06 & 402,69 & 255,81 & 605,23 & 464,10 & 360,27 & 563,85 \\
\hline 545 & 026075 silva telles & 260,17 & 295,39 & 467,78 & 447,48 & 471,07 & 2196,48 & 923,03 & 571,89 & 628,06 \\
\hline 546 & 026075bresser & 416,28 & 393,85 & 703,07 & 672,17 & 526,41 & 2280,23 & 1349,51 & 658,99 & 723,72 \\
\hline 547 & 026075j boemer & 260,17 & 295,39 & 421,06 & 402,69 & 255,81 & 605,23 & 349,81 & 353,99 & 414,92 \\
\hline 548 & 026075sta rita & 260,17 & 295,39 & 467,78 & 447,48 & 255,81 & 647,75 & 432,98 & 355,31 & 540,70 \\
\hline
\end{tabular}

Atualização:

http://www.fee.tche.br/sitefee/pt/content/servicos/pg_atualizacao_valores.php

\begin{tabular}{|l|c|c|c|c|c|c|c|c|c|}
\hline & vv 1953 & vv 1966 & vv 1978 & vv 1980 & vv 1988 & vv 1990 & vv 1991 & vv 2000 & vv 2002 \\
\hline \multicolumn{1}{|c|}{ mês/ano } & dez/52 & dez/65 & dez/77 & dez/79 & dez/87 & dez/89 & dez/90 & dez/99 & dez/01 \\
\hline valor & 150,00 & 5000,00 & 206,00 & 467,00 & 1422,00 & 732,00 & 13615,00 & 111,88 & 160,63 \\
\hline $\begin{array}{l}\text { fator de } \\
\text { correção }\end{array}$ & 0,520348 & 0,009846 & 0,562909 & 0,237014 & 0,108718 & 0,654297 & 0,032351 & 1,920199 & 1,567521 \\
\hline
\end{tabular}


Anexo 3

\title{
Uso do solo
}

\author{
Distrito do Pari
}

por quadra 


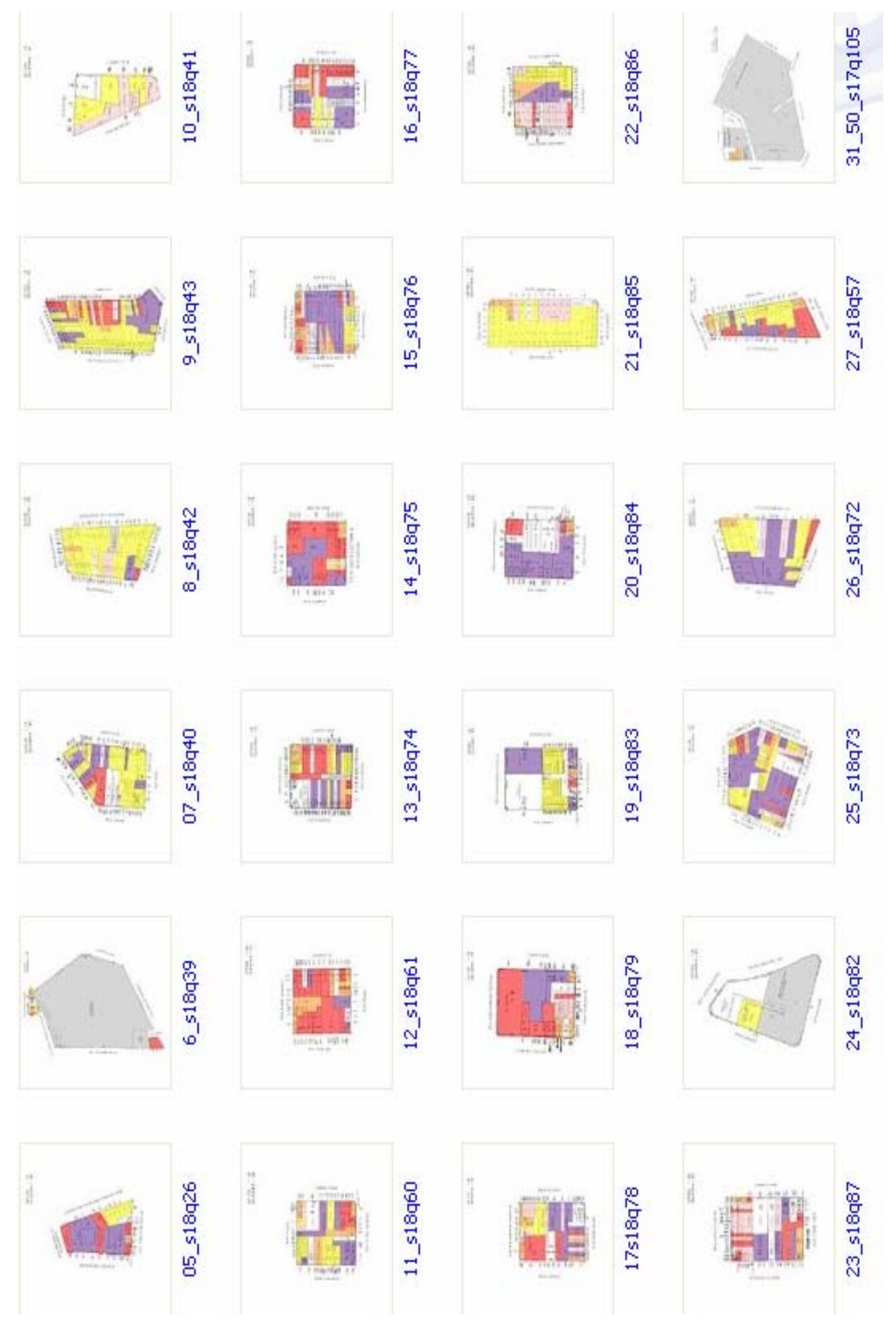



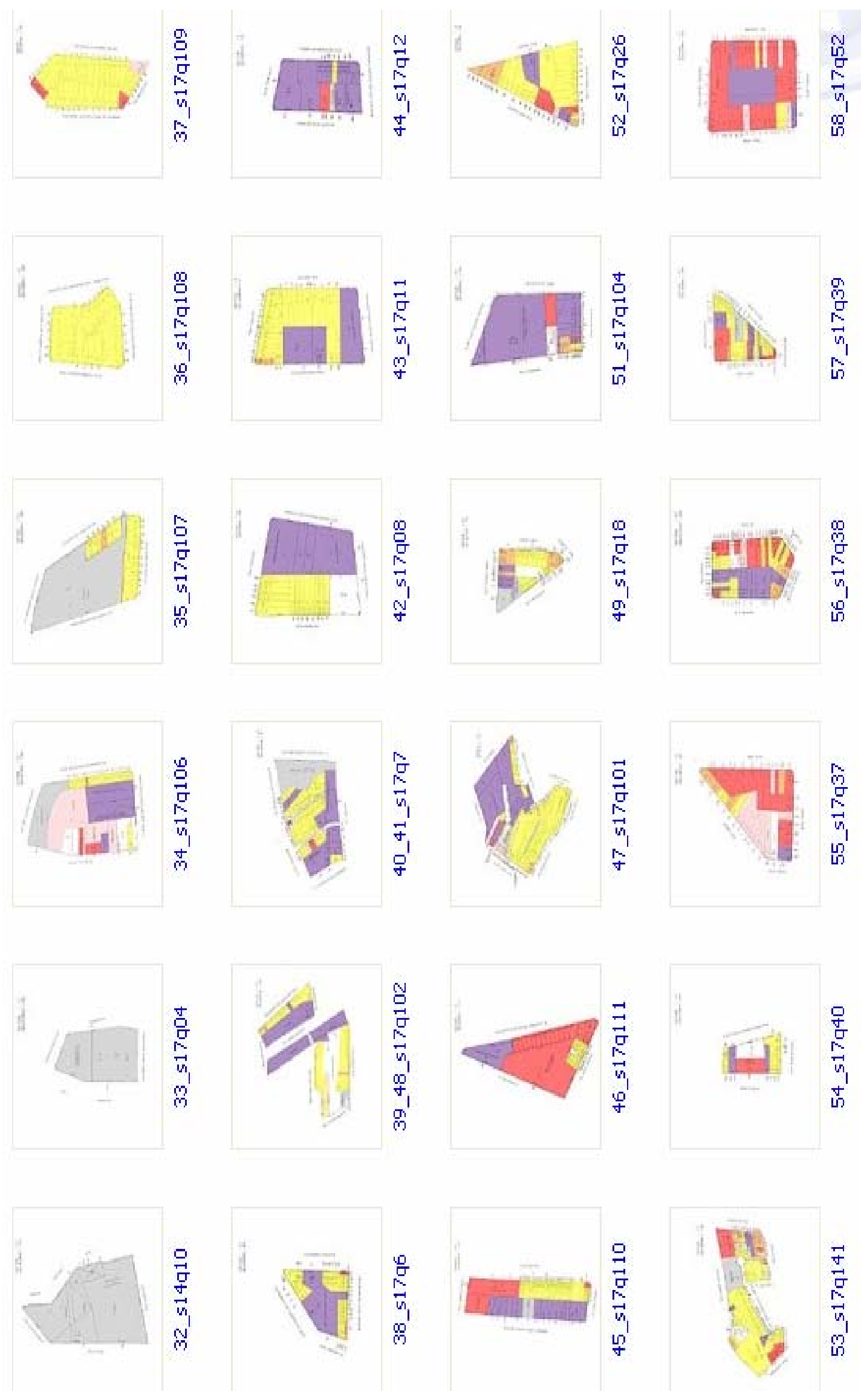


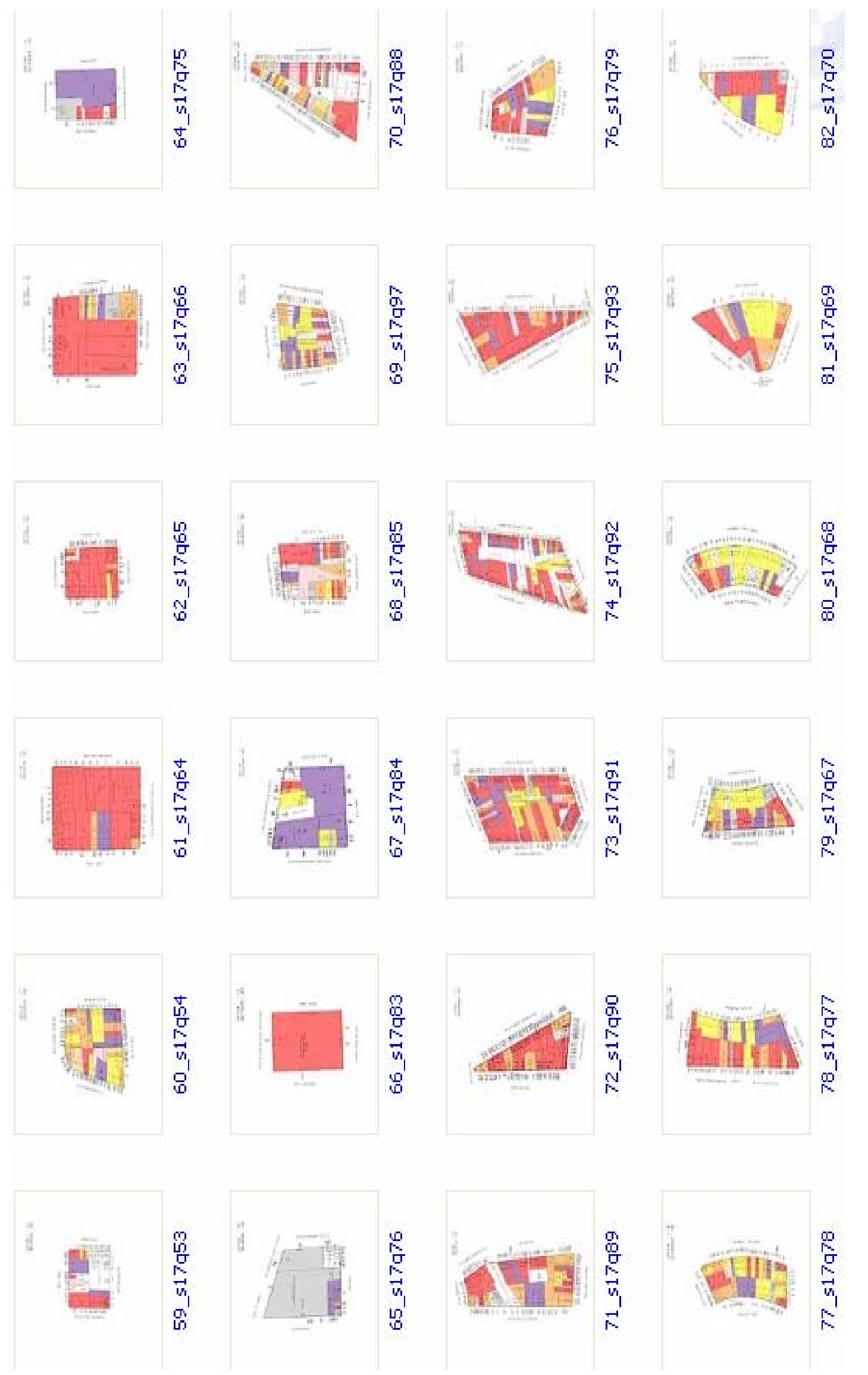




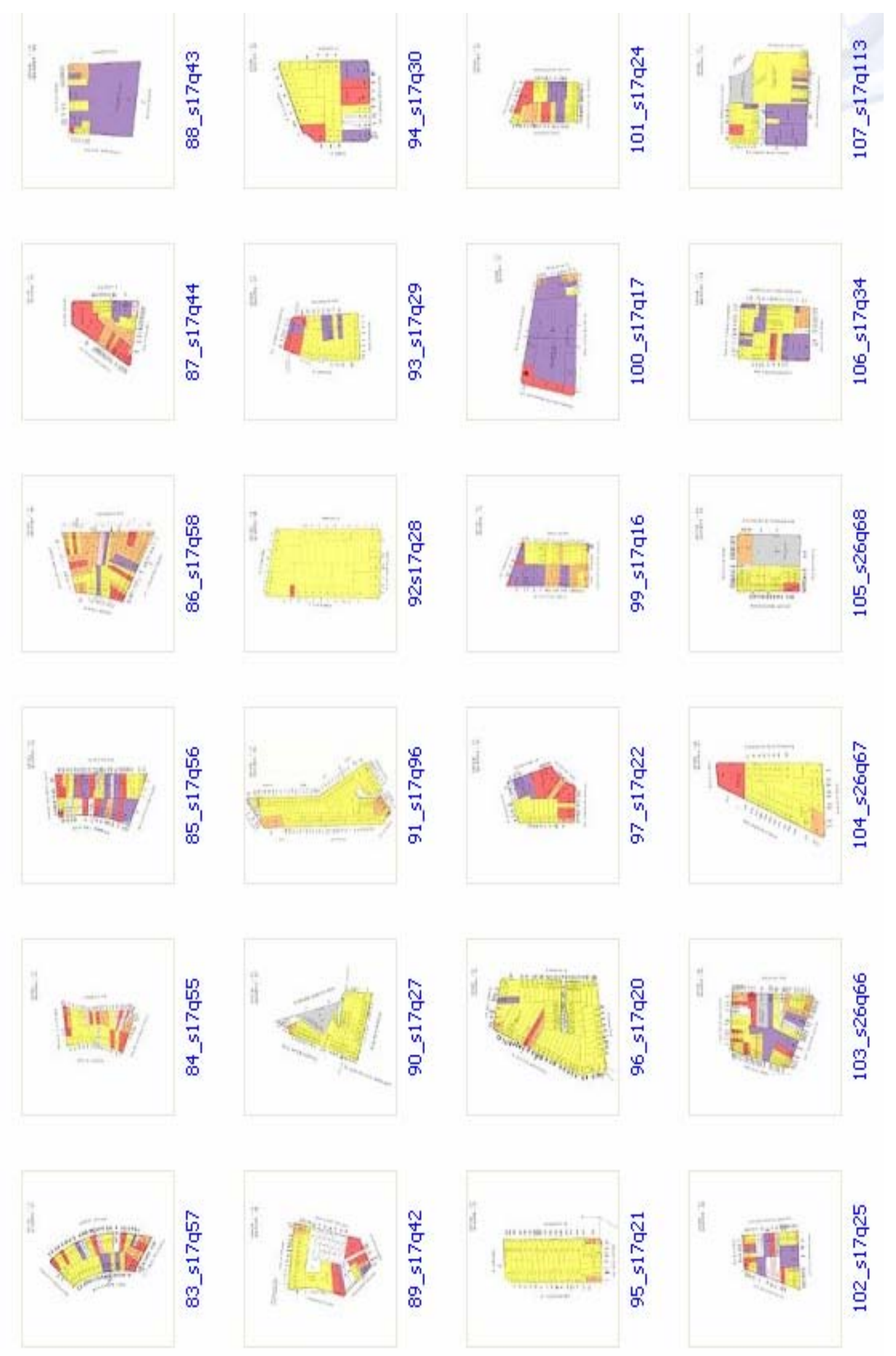




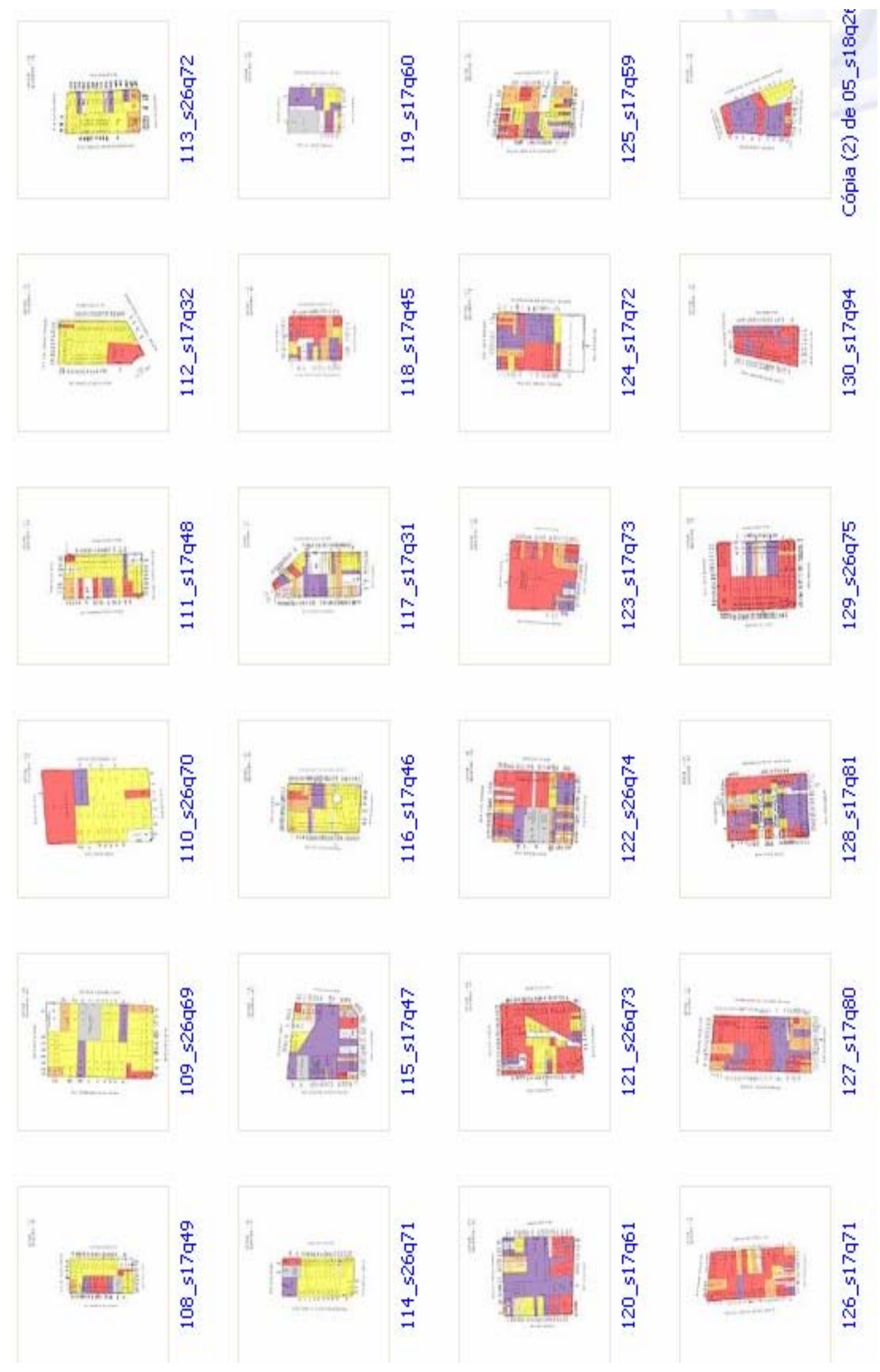




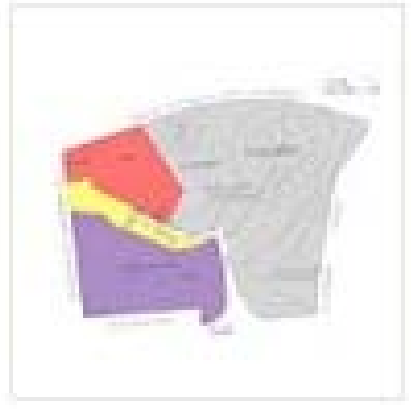

5170103

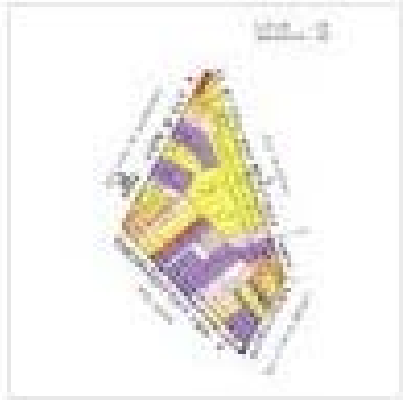

$518 \mathrm{5} 58$

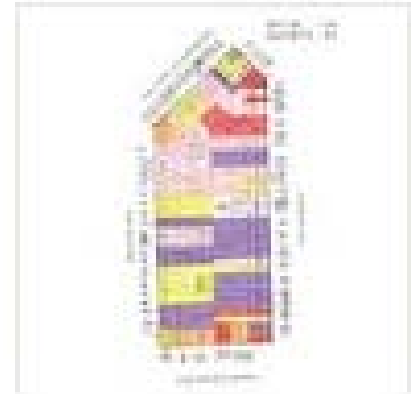

$\$ 18 \square 59$

LEGENDA DE USOS

RESIDENCIAL

COMERCIAL / SERVIÇOS

USO MISTO

$\square$ INSTITUCIONAL

INDÚSTRIA/OFICINA/DEPOSITO

CORTIÇO / FAVELA

VAZIO/CONSTR./ ESTAC./ REFORMA/

ALUGAR/VENDER

SOBREPOSICCÃO DE USOS

(OFICINA/RESIDENCIAL)

V4 EDIFICIO VERTICAL (4 ANDARES) 


\section{QUESTIONÁRIO 1 - Pari / moradores}

Nome (IDENTIFICAÇÃO OPCIONAL):

Endereço:

SQL:

1. Quantas pessoas moram em sua casa?

2. Quantos cômodos possuem sua casa?

3. Quantas horas você passa por dia dentro de sua casa?

4. Quais as atividades que vc faz dentro de casa?

5. Faz as refeições em casa? Quais?

6. Dorme em casa?

7. Você gosta de ficar em casa?

8. Você gosta de ficar no bairro?

9. Você recebe visitas? Do bairro ou de longe? Parentes ou amigos?

10. O que falta na sua casa? Móveis? Eletrodomésticos? Mais cômodos? Quintal?

11. Qual o cômodo da casa que é mais ocupado? Por que?

12. Quanto tempo mora na casa?

13. Quanto tempo mora no bairro?

14. Onde nasceu?

15. Qual é sua cor?

16. De onde vieram seus pais?

17. A casa é sua?

18. Desde quando?

19. Se não é, paga aluguel? Quanto?

20. Trabalha?

21. Qual é a sua profissão?

22. Qual é sua religião

23. O que faz no tempo livre?

24. Quem é o chefe de família?

25. Qual sua idade (chefe)?

26. Trabalha? Em que? (chefe)

27. Qual a escolaridade? (chefe)

28. Onde trabalha? No bairro? (chefe)

29. Qual é a renda familiar? 


\section{QUESTIONÁRIO 2 - Pari / empresa}

Nome da empresa:

Endereço:

SQL:

1. Qual é a atividade?

2. E a especialidade?

3. Existem filiais do estabelecimento? Onde?

4. Qual é o horário de funcionamento?

5. Quantas pessoas trabalham na empresa?

6. Qual é a área ocupada aproximadamente?

7. Existe refeitório na empresa?

8. Se não, onde os empregados almoçam?

9. O imóvel é de propriedade da empresa?

10. Se não, é alugado? Quanto paga?

11. Quanto tempo o estabelecimento está aqui?

12. Quanto tempo está no bairro?

OBS: Condições do imóvel: 


\section{QUESTIONÁRIO 3 - Pari / Freqüentadores}

Nome (IDENTIFICAÇÃO OPCIONAL):

Endereço de moradia:

1. Onde mora?

2. O que faz no bairro do Pari?

3. Quantas horas você passa por dia no bairro?

4. Quanto tempo leva para chegar aqui?

5. Faz as refeições no bairro?onde?

6. Você gosta do bairro?

7. Há quanto tempo freqüenta o bairro?

8. Onde nasceu?

9. Qual é sua cor?

10. De onde vieram seus pais?

11. Trabalha?

12. Qual é a sua profissão?

13. Qual é sua religião

14. O que faz no tempo livre?

15. Qual sua idade?

16. Qual a escolaridade?

17. Onde trabalha? No bairro?

18. Qual é a renda familiar?

OBS: 